PNL-10365

UC-3

1600

\title{
Commercial Equipment Cost Database
}

\author{
S. L. Freeman
}

January 1995

Prepared for

the U.S. Department of Energy

under Contract DE-AC06-76RLO 1830

Pacific Northwest Laboratory

Richland, Washington 99352 



\section{DISCLAIMER}

This report was prepared as an account of work sponsored by an agency of the United States Government. Neither the United States Government nor any agency thereof, nor any of their employees, make any warranty, express or implied, or assumes any legal liability or responsibility for the accuracy, completeness, or usefuiness of any information, apparatus, product, or process disclosed, or represents that its use would not infringe privately owned rights. Reference herein to any specific commercial product, process, or service by trade name, trademark, manufacturer, or otherwise does not necessarily constitute or imply its endorsement, recommendation, or favoring by the United States Government or any agency thereof. The views and opinions of authors expressed herein do not necessarily state or reflect those of the United States Government or any agency thereof. 


\section{DISCLAIMER}

Portions of this document may be illegible in electronic image products. Images are produced from the best available original document. 


\section{Summary}

The passage of the 1992 Energy Policy Act (EPAct) (42 USC 13201) brings commercial equipment under the scope of federal energy efficiency regulations for the first time. Categories of equipment covered by these regulations include commercial package heating and air-conditioning equipment, warm air furnaces, packaged boilers, and hot water heaters. In setting standards for these equipment categories, minimum efficiency levels are based on voluntary standards promoted by the American Society of Heating, Refrigerating, and Air-Conditioning Engineers (ASHRAE) in the document entitled Energy Code for Commercial and High-Rise Residential Building (ASHRAE/IES 90.1-1989) (ASHRAE 1993). EPAct further requires that if the ASHRAE standards are amended, the Secretary of Energy shall establish an amended national standard at the minimum level specified in the amended ASHRAE standard, unless a more stringent standard can be shown to result in significant additional energy savings, and is both technologically feasible and economically justified. A revised ASHRAE standard is currently under development, and in compliance with EPAct, the U.S. Department of Energy (DOE) has undertaken an evaluation of the standards development process.

This report, prepared for DOE, Office of Codes and Standards, as part of the Commercial Equipment Standards Program at Pacific Northwest Laboratory, specifically addresses the equipment cost estimates used to evaluate the economic impacts of revised standards. A database including commercial equipment list prices and estimated contractor costs was developed, and through statistical modeling, estimated contractor costs are related to equipment parameters including performance. These models are then used to evaluate cost estimates developed by the ASHRAE 90.1 Standing Standards Project Committee, which is in the process of developing a revised ASHRAE 90.1 standard. The database will also be used to support further evaluation of the manufacturer and consumer impacts of standards. Cost estimates developed from the database will serve as inputs to economic modeling tools, which will be used to estimate these impacts.

Preliminary results suggest that list pricing is a suitable measure from which to estimate contractor costs for commercial equipment. Models developed from these cost estimates accurately predict estimated costs. The models also confirm the expected relationships between equipment characteristics and cost. Cost models were developed for gas-fired and electric water heaters, gas-fired packaged boilers, and warm air furnaces for indoor installation. Because of industry concerns about the use of the data, information was not available for the other categories of EPAct-covered equipment. These concerns must be addressed to extend the analysis to all EPAct equipment categories. 



\section{Contents}

Summary $\quad \ldots \ldots \ldots \ldots \ldots \ldots \ldots \ldots \ldots \ldots \ldots \ldots \ldots \ldots \ldots \ldots \ldots$

1.0 Introduction $\ldots \ldots \ldots \ldots \ldots \ldots \ldots \ldots \ldots \ldots \ldots \ldots \ldots \ldots \ldots$

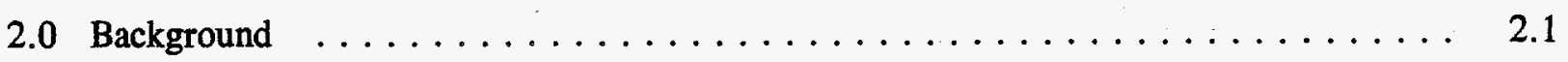

2.1 Evaluation of Cost Data $\ldots \ldots \ldots \ldots \ldots \ldots \ldots \ldots \ldots \ldots \ldots \ldots \ldots \ldots$

2.1.1 Market Effects on Cost Data Consistency $\ldots \ldots \ldots \ldots \ldots \ldots$

2.1.2 Specificity of Equipment Characterization $\ldots \ldots \ldots \ldots \ldots \ldots$

2.2 Evaluation of Performance Data $\ldots \ldots \ldots \ldots \ldots \ldots \ldots \ldots \ldots$

2.3 Availability of Cost and Performance Data $\ldots \ldots \ldots \ldots \ldots \ldots$

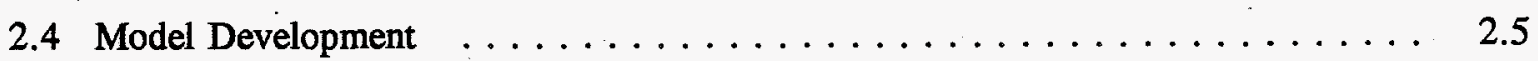

3.0 Definition of Equipment Categories $\ldots \ldots \ldots \ldots \ldots \ldots \ldots \ldots \ldots \ldots \ldots \ldots$

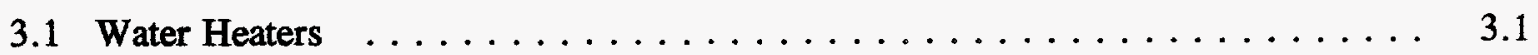

3.2 Packaged Boilers $\ldots \ldots \ldots \ldots \ldots \ldots \ldots \ldots \ldots \ldots \ldots \ldots \ldots \ldots \ldots \ldots$

3.3 Warm Air Furnaces $\ldots \ldots \ldots \ldots \ldots \ldots \ldots \ldots \ldots \ldots \ldots \ldots \ldots \ldots \ldots$

4.0 Description of ASHRAE Cost Analysis Methodology $\ldots \ldots \ldots \ldots \ldots \ldots$

4.1 Water Heaters $\ldots \ldots \ldots \ldots \ldots \ldots \ldots \ldots \ldots \ldots \ldots \ldots \ldots$

4.1.1 Baseline Cost Estimates $\ldots \ldots \ldots \ldots \ldots \ldots \ldots \ldots \ldots \ldots \ldots$

4.1.2 Incremental Cost Estimates $\ldots \ldots \ldots \ldots \ldots \ldots \ldots \ldots \ldots \ldots$

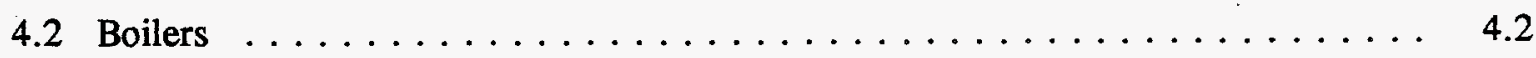

4.2 .1 Baseline Cost Estimates $\ldots \ldots \ldots \ldots \ldots \ldots \ldots \ldots \ldots \ldots \ldots$

4.2.2 Incremental Cost Estimates $\ldots \ldots \ldots \ldots \ldots \ldots \ldots \ldots \ldots \ldots$

4.3 Warm Air Furnaces $\ldots \ldots \ldots \ldots \ldots \ldots \ldots \ldots \ldots \ldots$

4.3.1 Baseline Cost Estimates $\ldots \ldots \ldots \ldots \ldots \ldots \ldots \ldots \ldots \ldots$ 
4.3.2 Incremental Cost Estimates $\ldots \ldots \ldots \ldots \ldots \ldots \ldots \ldots \ldots \ldots$

5.0 Database Description $\ldots \ldots \ldots \ldots \ldots \ldots \ldots \ldots \ldots \ldots \ldots \ldots \ldots$

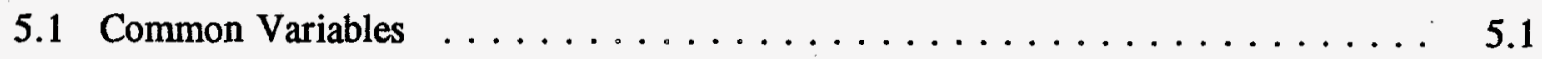

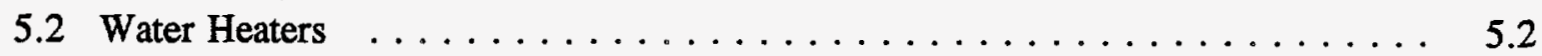

5.2 .1 Fuel-Fired Storage Water Heaters $\ldots \ldots \ldots \ldots \ldots \ldots \ldots . \ldots \ldots$

5.2 .2 Tankless Water Heaters $\ldots \ldots \ldots \ldots \ldots \ldots \ldots \ldots \ldots \ldots \ldots \ldots$

5.2 .3 Electric Storage Water Heaters $\ldots \ldots \ldots \ldots \ldots \ldots \ldots \ldots$

5.2.4 Unfired Hot Water Storage Tanks $\ldots \ldots \ldots \ldots \ldots \ldots \ldots \ldots$

5.3 Packaged Boilers $\ldots \ldots \ldots \ldots \ldots \ldots \ldots \ldots \ldots \ldots \ldots \ldots$

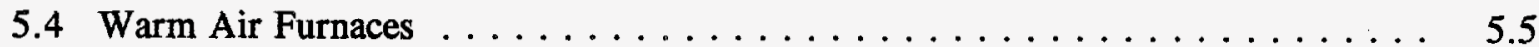

6.0 Estimate of Baseline Consumer Costs $\ldots \ldots \ldots \ldots \ldots \ldots \ldots \ldots \ldots \ldots \ldots \ldots$

6.1 Water Heaters $\ldots \ldots \ldots \ldots \ldots \ldots \ldots \ldots \ldots \ldots \ldots \ldots \ldots \ldots \ldots \ldots$

6.1 .1 Fuel-Fired Storage Water Heaters $\ldots \ldots \ldots \ldots \ldots \ldots \ldots . \ldots \ldots$

6.1 .2 Tankless Water Heaters $\ldots \ldots \ldots \ldots \ldots \ldots \ldots \ldots \ldots \ldots$

6.1 .3 Electric Storage Water Heaters $\ldots \ldots \ldots \ldots \ldots \ldots \ldots . \ldots . \ldots$

6.1 .4 Unfired Hot Water Storage Tanks $\ldots \ldots \ldots \ldots \ldots \ldots \ldots . \ldots \ldots$

6.2 Packaged Boilers $\ldots \ldots \ldots \ldots \ldots \ldots \ldots \ldots \ldots \ldots \ldots \ldots \ldots$

6.3 Warm Air Furnaces $\ldots \ldots \ldots \ldots \ldots \ldots \ldots \ldots \ldots \ldots \ldots$

7.0 Estimate of High-Efficiency Incremental Cost $\ldots \ldots \ldots \ldots \ldots \ldots \ldots$

7.1 Water Heaters $\ldots \ldots \ldots \ldots \ldots \ldots \ldots \ldots \ldots \ldots \ldots \ldots \ldots \ldots \ldots$

7.1 .1 Fuel-Fired Storage Water Heaters $\ldots \ldots \ldots \ldots \ldots \ldots \ldots \ldots$

7.1.2 Tankless Water Heaters $\ldots \ldots \ldots \ldots \ldots \ldots \ldots \ldots \ldots \ldots \ldots . \ldots \ldots$

7.1.3 Electric Storage Water Heaters $\ldots \ldots \ldots \ldots \ldots \ldots \ldots \ldots$

7.1.4 Unfired Hot Water Storage Tanks $\ldots \ldots \ldots \ldots \ldots \ldots \ldots . \ldots . \ldots$ 
7.2 Packaged Boilers $\ldots \ldots \ldots \ldots \ldots \ldots \ldots \ldots \ldots \ldots$

7.3 Warm Air Furnaces $\ldots \ldots \ldots \ldots \ldots \ldots \ldots \ldots \ldots \ldots \ldots \ldots$

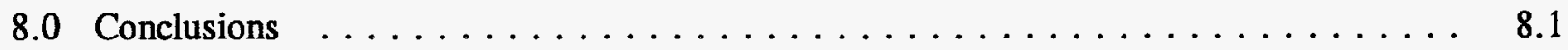

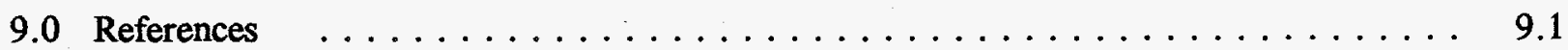

Appendix A - Equipment Database Tables $\ldots \ldots \ldots \ldots \ldots \ldots \ldots \ldots \ldots$ 


\section{Tables}

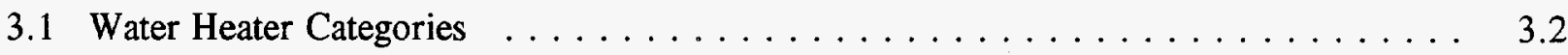

4.1 ASHRAE Water Heater Baseline Cost Estimates $\ldots \ldots \ldots \ldots \ldots \ldots \ldots$

4.2 ASHRAE Water Heater Incremental Cost Estimates $\ldots \ldots \ldots \ldots \ldots \ldots$

4.3 ASHRAE Atmospheric Burner Cast-Iron Boiler Baseline Cost Estimates $\quad \ldots \ldots \ldots$

4.4 ASHRAE Power Burner Cast-Iron Boiler Baseline Cost Estimates $\ldots \ldots \ldots$. . . . . 4.4

4.5 ASHRAE Steel Water-Tube Boiler Baseline Cost Estimates $\ldots \ldots \ldots \ldots \ldots$

4.6 ASHRAE Steel Fire-Tube and Scotch Marine Boiler Baseline Cost Estimates _. . . . . 4.5

4.7 ASHRAE Hot Water Boiler Incremental Cost Estimates $\ldots \ldots \ldots \ldots \ldots$

4.8 ASHRAE Steam Boiler Incremental Cost Estimates $\ldots \ldots \ldots \ldots \ldots \ldots$

4.9 ASHRAE Outdoor Furnace Baseline Cost Estimates $\ldots \ldots \ldots \ldots \ldots \ldots$

4.10 ASHRAE Outdoor Furnace Incremental Cost Estimates $\ldots \ldots \ldots \ldots \ldots$

6.1 Fuel-Fired Storage Water Heater Categories $\ldots \ldots \ldots \ldots \ldots \ldots \ldots$

6.2 Comparison of ASHRAE and Modeled Baseline Cost Estimates for Low-Input Fuel-Fired Storage Water Heaters $\ldots \ldots \ldots \ldots \ldots \ldots \ldots \ldots$

6.3 Comparison of ASHRAE and Modeled Baseline Cost Estimates for High-Input Fuel-Fired Storage Water Heaters $\ldots \ldots \ldots \ldots \ldots \ldots \ldots$

6.4 Comparison of ASHRAE and Modeled Baseline Cost Estimates for Tankless Water Heaters $\ldots \ldots \ldots \ldots \ldots \ldots \ldots \ldots \ldots \ldots . \ldots \ldots \ldots$

6.5 Comparison of ASHRAE and Modeled Baseline Cost Estimates for Unfired Hot Water Storage Tanks

6.6 Comparison of ASHRAE and Modeled Baseline Cost Estimates for Standard and ASME Construction Hot Water Storage Tanks

6.7 Comparison of ASHRAE and Modeled Baseline Cost Estimates for Cast-Iron Hot Water Boilers

7.1 Comparison of ASHRAE and Modeled Incremental Cost Estimates for High-Efficiency Fuel-Fired Storage Water Heaters 
7.2 Comparison of ASHRAE and Modeled Incremental Cost Estimates for Tankless

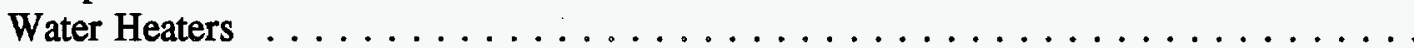

7.3 Incremental Material Cost Estimates for Highly Insulated Hot Water Storage Tanks

7.4 Comparison of ASHRAE and Modeled Incremental Cost Estimates for Packaged Atmospheric Hot Water Boilers $(800 \mathrm{kBtu} / \mathrm{hr}) \ldots \ldots \ldots \ldots \ldots . \ldots$

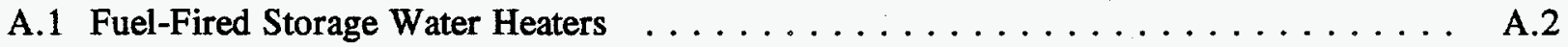

A.2 Tankless Water Heaters $\ldots \ldots \ldots \ldots \ldots \ldots \ldots \ldots \ldots$

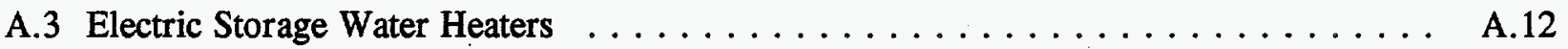

A.4 Unfired Hot Water Storage Tanks $\ldots \ldots \ldots \ldots \ldots \ldots \ldots \ldots \ldots \ldots \ldots \ldots$

A.5 Packaged Boilers $\ldots \ldots \ldots \ldots \ldots \ldots \ldots \ldots \ldots \ldots \ldots \ldots \ldots \ldots$

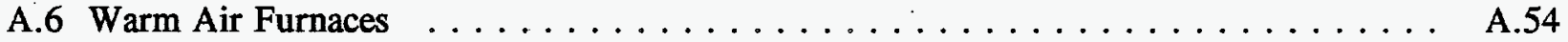




\subsection{Introduction}

If the economic impacts of commercial equipment efficiency standards are to be fully evaluated, all costs that are incurred in purchasing and operating the equipment over its assumed life must be estimated. This report primarily addresses equipment purchased cost estimates for both low- and highefficiency units and the appropriate performance measure(s) for the equipment. When the equipment cost data were developed, other information relevant to the life-cycle equipment costs was also available. Where appropriate, this information is discussed, especially when it relates to equipment purchased costs and equipment operating costs.

The analysis relies primarily on a database of equipment cost and performance information. A partial version of this database is included in Appendix A, with manufacturer-specific information and some cost data excluded to protect the proprietary interests of the manufacturers. This database was developed from list price information supplied by manufacturers of commercial equipment; catalog data on the features and characteristics of the equipment; and performance information derived from a variety of sources including the manufacturers, equipment catalogs, equipment directories, and other databases. In addition, the manufacturers were asked to supply estimated multipliers for converting list prices to wholesale prices, allowing price comparisons between companies. Contractor pricing is estimated from wholesale prices assuming a dealer markup of $10 \%$. Finally, consumer costs are estimated assuming a contractor markup of $25 \%$, which does not include the cost of labor for equipment installation or the peripheral equipment necessary to install the equipment. The two cost measures held in the database are list price and estimated contractor price.

The database is used to develop estimates of the baseline contractor costs for standard-efficiency equipment as well as the incremental costs for high-efficiency equipment. Because the database relies on information about existing equipment, it reflects costs associated with the actual features and characteristics of both standard- and high-efficiency equipment currently available on the market. As such, the data may not cover the entire spectrum of technologically achievable performance. The results also reflect market factors that affect equipment costs beyond the actual costs that are associated with the production and distribution of the equipment. The cost estimates are used to evaluate cost information generated by the American Society of Heating, Refrigerating and Air-Conditioning Engineers (ASHRAE) in the development of a revised ASHRAE Standard 90.1.

The database in Appendix A includes information on water heaters, hot water storage tanks, packaged boilers, and warm air furnaces. Information was requested from manufacturers of heating, ventilating, and cooling (HVAC) equipment; however, there was an extreme reluctance to provide these data, especially among the major manufacturers. A formal request for data was presented through the Air Conditioning and Refrigeration Institute (ARI) to its members, which include most of the manufacturers of commercial HVAC equipment. This request was turned down. The Gas Appliance Manufacturers Association (GAMA) also formally requested that the U.S. Department of Energy (DOE) desist from current cost data collection efforts until after the ASHRAE analysis is completed. As a result, 
data were not collected from several major boiler manufacturers. The analysis was completed using the boiler information available, but sufficient data does not currently exist on HVAC equipment to warrant inclusion in the database.

Baseline and incremental cost information that was collected in this study is also intended for use in evaluating the consumer and manufacturer impacts of efficiency standards. This work is being conducted by the Commercial Equipment Standards Program at Pacific Northwest Laboratory, ${ }^{(a)}$ under contract to DOE, Office of Codes and Standards. The cost data will serve as inputs to economic models that are used to evaluate the impacts of revised standards.

(a) Pacific Northwest Laboratory (PNL) is operated for the U.S. Department of Energy by Battelle Memorial Institute under Contract DE-AC06-76RLO 1830. 


\subsection{Background}

Several potential sources of cost and performance information are available for commercial equipment. The following chapter discusses some of the strengths and weaknesses of these information sources and also discusses how the data can be used to relate equipment costs to equipment. characteristics.

\subsection{Evaluation of Cost Data}

Accurately evaluating average commercial equipment costs is difficult. Competitive pricing at the wholesale, dealer, and contractor levels leads to wide variation in consumer costs for a particular piece of equipment. Comparing equipment prices between manufacturers requires that a consistent measure of cost be identified.

\subsubsection{Market Effects on Cost Data Consistency}

At the manufacturing level, costs are typically measured as "standard costs," which reflect the estimated cost (not including sales and general administration costs) to produce a typical model. A change in standard costs over a given time period is referred to as variance, where a positive variance represents average production costs above the expected standard cost. If the variance is generally small with respect to standard cost and the standard cost is consistently defined across a given sector of the manufacturing industry, the standard cost would be an appropriate measure of manufactured cost. Unfortunately, manufactured cost information is very closely guarded. This is partly due to the fact that a manufacturer's competitors can obtain detailed information about its products simply by purchasing them. Therefore, production cost information remains one of the few competitive secrets that can be maintained. Even if standard costs are a consistent measure of equipment costs between companies, this information is difficult to obtain.

Manufactured costs can also be expected to fluctuate substantially as a result of short-term market conditions. Equipment manufacturers rely to a varying extent on suppliers to provide components for the equipment. As demand for equipment rises, the manufacturers may turn to secondary suppliers of components to meet short-term demands. This may, in turn, result in higher component costs, though the essential characteristics of the equipment remain unchanged. In a competitive market, these costs may not be passed on to the consumer and may not be reflected in retail equipment prices.

Difficulties also occur in the collection of consistent cost information at a defined point in the equipment distribution chain. This happens primarily because of the variety and complexity of distribution mechanisms found in the commercial equipment market. As an example, consider two extreme cases of different marketing systems. In one system, equipment is marketed through distributors who purchase the equipment based on a published price list. The actual price paid for the equipment is discounted from the published price based on the dollar volume of sales, the number of models stocked by the distributor, and the terms of the sale (cash paid in a specific time frame after shipment). Also, 
these published prices may vary by region. In another system, a small company that manufactures a low volume of high-efficiency equipment may market that same equipment directly to consumers. Identifying a consistent cost measure for comparing equipment from these two types of companies is difficult.

Because consumer costs for equipment are in many cases the desired measure, it is also possible to try to collect this information directly. However, commercial equipment is typically not sold at a retail level, making consumer cost difficult to collect. Commercial equipment is usually purchased and installed by a contractor who charges the consumer for the cost of the equipment plus some markup to cover overhead and profit for the project. Contractors base this markup on the characteristics of the project and the relationship to the customer. In general, the greater the level of competition in an area and the lower the level of risk involved in the project, the less the equipment will be marked up. Estimated markups can range from less than $15 \%$ to greater than $50 \%$, thus heavily impacting the actual consumer cost for the equipment. Because of the factors involved in project bidding, it is generally difficult to obtain equipment cost estimates from contractors without specifying the exact details of the project.

Other potential sources of consumer cost data for commercial equipment are utility rebate programs that offer incentives to customers based on the cost of the equipment. If sufficient information is recorded in these programs, it would serve as a source of data on actual equipment costs at the consumer level. An evaluation of this data source suggests, however, that the quality and quantity of commercial equipment cost data available through rebate programs is limited and, in many cases, may be considered proprietary.

Finally, equipment distributors can provide cost information for equipment at the contractor level. These costs will reflect all of the variations found in the distribution chain, including regional factors that affect price. Estimating national average values, however, makes it necessary to request data from a wide number of distributors. Collecting information from distributors also has other limitations. First, prices charged by a given distributor may vary depending on the relationship with an individual contractor. Second, contractor cost information may be considered proprietary to disguise the variable rate structure between clients. Third, the collection of large quantities of information through this method would be difficult because no published contractor costs are available. Thus, while distributor pricing may be the best information available for estimating consumer costs, it would be difficult to develop a large data set based on this source.

The primary cost data source used in this analysis was manufacturer-supplied list pricing. Because list prices are not necessarily comparable between manufactures, list price information was converted to estimated wholesale price where wholesale price is defined as the price paid by a distributor for the equipment. Two methods were used to convert list prices to wholesale prices. When possible, equipment manufacturers were asked to provide a multiplier for calculating wholesale price from list price. Lacking manufacturer estimates, dealers were contacted for actual contractor price quotes, and these quotes were averaged to identify the relationship between list prices and contractor pricing. Estimated 
average dealer and contractor markups were then used to convert these costs to consumer costs. A similar multiplier can be used to estimate manufacturer costs.

\subsubsection{Specificity of Equipment Characterization}

Accurately measuring the cost of comparable pieces of equipment requires a detailed specification of the properties of that equipment. Without the ability to control for equipment features, any betweencompany comparison of equipment costs is impossible.

As an example, consider some common features of commercial electric water heaters. Frequently, these units can be purchased with either immersion or surface thermostats. The cost premium for an immersion thermostat model may be as much as an additional $30 \%$ over the cost of a surface thermostat model. Without knowledge of the thermostat type, it is clearly risky to compare the costs of two otherwise similar units. When incremental cost estimates are made from costs for existing equipment, it is important to understand the features associated with the equipment.

Baseline equipment cost estimates also affect the outcome of life-cycle cost calculations. As first costs for equipment escalate, the impact of fuel savings on the life-cycle cost diminishes. An accurate assessment of average baseline equipment costs requires not only an understanding of common equipment features and costs, but also an understanding of the market penetration of these features.

\subsection{Evaluation of Performance Data}

Performance information plays an integral role in the estimation of life-cycle consumer costs for commercial equipment. In this type of analysis, incremental costs for high-efficiency equipment are essentially weighed against the value of fuel savings over the life of the equipment. If the present value of fuel savings is greater than the present value of increased capital or other costs, then the life-cycle cost is lower at higher levels of efficiency, justifying a more stringent standard. While life-cycle cost minimization is only one of many possible decision rules in any life-cycle cost assessment, the actual life-cycle performance of the equipment has an important effect on the estimation of life-cycle cost.

Standard measures of performance have been developed for commercial equipment by a variety of groups and agencies, including DOE, ASHRAE, American National Standards Institute (ANSI), and Underwriters Laboratories (UL). These standards describe a detailed test situation in which the performance of a specific piece of equipment is measured in the laboratory. The standards are designed to ensure consistent ratings of equipment produced by different manufacturers. Performance testing for commercial equipment primarily focuses on the steady-state performance, however, which typically does not reflect the actual seasonal performance of the equipment. Thus, evaluation of lifecycle costs based on steady-state performance measures does not accurately reflect the actual fuel consumption and fuel costs associated with equipment operation.

This issue is particularly pertinent when evaluating high-efficiency equipment. Achieving such high efficiencies makes it necessary to depart radically from conventional design parameters. 
Examples of such types of equipment include modulating condensing water heaters and boilers, pulse combustion furnaces and boilers, and direct contact water heaters. Standard test procedures applied to these types of equipment may grossly underestimate or overestimate the annual fuel consumption, and thus fuel costs.

As an example, consider the modulating water heater referred to above. Under steady-state conditions at maximum-rated capacity, the tested thermal efficiency (ANSI Z21.10.3) is $93 \%$. This efficiency goes up as input decreases, approaching $99 \%$ efficiency at 10:1 turndown ratio. In this case, the seasonal performance of the unit, because of part load operation, is most likely higher than the steady-state, full-fire efficiency. Evaluating life-cycle costs for this equipment based on rated input efficiency will overestimate fuel consumption and costs.

Conversely, many types of equipment operate less efficiently under part load conditions. In a report that evaluated seasonal performance of conventional steam boilers, the results of three studies covering 13 boilers were analyzed. The steady-state efficiencies of this equipment ranged from $70 \%$ to $85.4 \%$, while the seasonal-efficiency estimates for the same equipment ranged from $56.6 \%$ to $73.7 \%$ (Hewett and Lobenstein 1992). Estimating fuel consumption based on steady-state performance is clearly inaccurate.

High-efficiency equipment may also require higher levels of maintenance than conventional equipment. This adds additional operating costs and, in the absence of sufficient maintenance, may add additional fuel costs as performance degrades. As an example, consider a boiler with a heat reclaimer added to the boiler stack to recover energy. Because of the added complexity to the system, a more sophisticated tuning process is required to achieve the expected peak performance. Properly tuned, the unit may operate at four percentage points above the conventional design. Without proper tuning, carbon may soot up the tube bundles and boiler, possibly reducing performance below that of a standard model.

Performance measures in this report are based on current test procedures. When life cycle costs are evaluated, it is important to remember the limitations of this type of performance information.

\subsection{Availability of Cost and Performance Data}

Manufacturers, manufacturer representatives, and dealers are frequently reluctant to release cost information. Even when a potential provider of information is identified, several contacts may be required before the information is released. Many manufacturers were contacted in this data collection effort, and repeated attempts were made to ensure the confidentiality of the information. However, in some cases, limited or no data were available. In the case of the HVAC equipment manufacturers, a further effort will be required to evaluate equipment costs. Because of the sensitivity of cost data in this report, specific manufacturers are not identified with regard to any cost information. Also, equipment parameters such as volume and input were rounded to further disguise the data. 
While performance data are more readily available, some types of performance information are difficult to collect and may be of poor quality. Though water heater performance data for most manufacturers are collected in the California Energy Commission (CEC) equipment database, thermalefficiency data are missing for many fuel-fired water heaters. Standby loss information is also missing for a significant fraction of storage-type water heaters. Some information of this type is available from the manufacturers, but it is often only a general estimate used in sales literature. The CEC database does not include unfired hot water storage tanks, and no other source of tested standby loss performance for this equipment was identified.

The CEC database also includes thermal-efficiency data for warm air furnaces and combustion efficiency data for boilers. An additional source of boiler efficiency information is the Hydronics Institute, which publishes ratings for Institute-certified equipment (Hydronics Institute 1994). A comparison of data from the two sources revealed only a few discrepancies in the efficiency measures. Where possible, information from the CEC database was used, as it provides the broadest coverage. Other sources were used to supplement these data.

\subsection{Model Development}

With consistent measures of cost and performance identified, statistical models can be developed relating costs to equipment parameters. When these models are developed, many subjective decisions must be made about the form of the models and the data to be included in the analysis. When residual plots and other statistical measures of goodness of fit are evaluated, it is possible to eliminate some models from consideration. In many cases, however, there are still several possible ways in which the data can be modeled. If outliers are eliminated, more accurate models can be developed for the remaining data. When there is little basis for excluding any particular data, however, other than the difficulty in modeling it, an attempt is made to revise the model to account for these data, either by including dummy variables or by regrouping the data into separate categories.

Model validity can also be measured by the extent to which parameter estimates reflect the expected relationships between equipment characteristics and cost. Because many of the explanatory variables used to characterize equipment are correlated, it is often difficult to account for the effect of each variable independently. If these correlations are understood, however, it is possible to choose a set of variables that, in general, reflect the most important parameters that affect cost.

Models are reported along with the R-squared value for the model. This is not meant to imply that a high R-squared value alone can be used as a measure of the validity of the model. In fact, R-squared values are a poor measure of model validity, and comparisons of $\mathbf{R}$-squared values between models are only useful in certain limited circumstances. In order to assess model validity other methods were used including the evaluation of t-statistics and standard errors, direct evaluation of predicted versus actual values, and the evaluation of tests for general model mispecification. In this way it is possible to choose models which are both statistically valid, and which reflect the most important characteristics which affect cost. 
It is also extremely important to understand the bounds of model validity. Any attempt to apply the model to equipment with characteristics outside of the bounds of the data set is invalid, and is likely to lead to poor estimates of cost, especially for models involving power and logarithmic functions. These bounds have generally been noted when estimating equipment costs, and any attempt to produce additional cost estimates using these models should only be carried out after a thorough examination of the relevant data set. 


\subsection{Definition of Equipment Categories}

EPAct standards only apply to certain categories of equipment, and these standards also vary between equipment subcategories. The following chapter describes the equipment categories found in EPAct.

\subsection{Water Heaters}

In EPAct, commercial water-heating equipment is divided into six categories. These categories are presented in Table 3.1.

The minimum input ratings for small-input fuel-fired storage water heaters and fuel-fired instantaneous water heaters with greater than 10-gal storage are different for gas and oil models. Minimum oil inputs are given in parenthesis. Because no significant difference was found in costs for largeinput, fuel-fired storage water heaters and for fuel-fired instantaneous water heaters with greater than 10-gal storage volume, these two categories are treated as one in this report and are referred to as fuelfired storage water heaters. The remaining small-storage instantaneous units are referred to as tankless water heaters. The characteristics of these equipment types are discussed further in Section 6.1 of this report.

\subsection{Packaged Boilers}

Commercial packaged boilers are defined in EPAct as units that are "...shipped complete with heating equipment, mechanical draft equipment, and automatic controls; usually shipped in one or more sections." This includes all equipment with rated capacity of $300,000 \mathrm{Btu} / \mathrm{hr}$ or more and includes oil- and gas-fired units and water and steam boilers. Separate standards exist for each fuel type, so they were examined separately.

\subsection{Warm Air Furnaces}

A warm air furnace is defined in EPAct as “...a self-contained oil- or gas-fired furnace designed to supply heated air through ducts to spaces that require it and includes combination warm air furnace/ electric air conditioning units but does not include unit heaters and duct furnaces." Commercial equipment includes all units with rated capacity of $225,000 \mathrm{Btu} / \mathrm{hr}$ or more. The ASHRAE analysis is based on outdoor-type warm air furnaces. Because few data were available from manufacturers of this type of equipment, baseline cost estimates were limited to warm air furnaces for indoor installation. 
Table 3.1. Water Heater Categories

\begin{tabular}{|l|l|l|l|l||}
\hline \multicolumn{1}{|c|}{ Type } & \multicolumn{1}{|c|}{ Input Rating } & \multicolumn{1}{c|}{$\begin{array}{c}\text { Storage } \\
\text { Volume }\end{array}$} & $\begin{array}{c}\text { Input-to-Storage } \\
\text { Volume Ratio }\end{array}$ & \multicolumn{1}{c|}{ Standard } \\
\hline $\begin{array}{l}\text { Storage } \\
\text { Electric }\end{array}$ & $>12 \mathrm{~kW}$ & All & All & $\leq 0.3+27 / \mathrm{Vol}$. \\
\hline $\begin{array}{l}\text { Fuel-Fired } \\
\text { Storage }\end{array}$ & $\begin{array}{l}>75(105) \mathrm{kBtu} / \mathrm{hr} \\
\leq 155 \mathrm{kBtu} / \mathrm{hr}\end{array}$ & All & All & $\begin{array}{l}\geq 78 \% \text { efficiency } \\
\leq 1.3+114 / \mathrm{Vol} .\end{array}$ \\
\hline $\begin{array}{l}\text { Fuel-Fired } \\
\text { Storage }\end{array}$ & $>155 \mathrm{kBtu} / \mathrm{hr}$ & $\geq 10 \mathrm{gal}$ & $<4,000 \mathrm{Btu} / \mathrm{hr}$ & $\begin{array}{l}\geq 78 \% \text { efficiency } \\
\leq 1.3+95 / \mathrm{Vol} .\end{array}$ \\
\hline $\begin{array}{l}\text { Fuel-Fired } \\
\text { Instantaneous }\end{array}$ & $>200(210) \mathrm{kBtu} / \mathrm{hr}$ & $<10 \mathrm{gal}$ & $\geq 4,000 \mathrm{Btu} / \mathrm{hr}$ & $\geq 80 \%$ efficiency \\
\hline $\begin{array}{l}\text { Fuel-Fired } \\
\text { Instantaneous }\end{array}$ & $>155 \mathrm{kBtu} / \mathrm{hr}$ & $\geq 10 \mathrm{gal}$ & $\geq 4,000 \mathrm{Btu} / \mathrm{hr}$ & $\begin{array}{l}\geq 77 \% \mathrm{efficiency} \\
\leq 2.3+67 / \mathrm{Vol} .\end{array}$ \\
\hline $\begin{array}{l}\text { Unfired } \\
\text { Storage Tanks }\end{array}$ & N/A & All & N/A & $\leq 6.5 \mathrm{Btu} / \mathrm{hr} / \mathrm{ft}^{2}$ \\
\hline
\end{tabular}




\subsection{Description of ASHRAE Cost Analysis Methodology}

When evaluating the cost of commercial equipment, ASHRAE relied on two primary types of information: estimated contractor cost for typical equipment and estimated incremental cost for highefficiency equipment. Contractor pricing for the baseline units was developed by an engineering consultant who contacted equipment distributors and asked them for equipment costs (by size) for up to four separate models and different sizes in each category. These estimates were inflated by $25 \%$ to account for contractor markup and then averaged. Incremental costs above this baseline were estimated based on information supplied by manufacturers through associations such as GAMA and ARI. The manufacturers were asked in a survey to estimate the incremental cost, as a percentage, to produce equipment at varying levels of efficiency above an assumed baseline. These incremental cost percentages were then multiplied by the baseline costs to develop equipment costs at each of the desired efficiency levels. The specific details of the cost collection exercise varied for each of the major equipment categories and are described below.

\subsection{Water Heaters}

Cost estimates for water heater equipment were made for 10 specific equipment types and sizes. Only gas-fired equipment was considered in this analysis.

\subsubsection{Baseline Cost Estimates}

Baseline cost estimates are presented in Table 4.1. These costs are for equipment only and include an estimated $25 \%$ contractor markup. The contractor markup does not include labor costs to install the equipment. The first four entries are gas-fired water heaters with storage tanks. Based on the ASHRAE water heater classifications, the first three models are storage water heaters, having an inputto-volume ratio of less than $4,000 \mathrm{Btu} / \mathrm{hr} / \mathrm{gal}$. The fourth model, based on this ratio, is an instantaneous water heater with greater than a 10 -gal storage volume. The second set of equipment, labeled instantaneous water heaters, are of copper finned-tube design. These units have no storage volume other than the quantity of water held in the tubing of the equipment. These units are essentially equivalent to hydronic-heating models, which are classified as boilers. Finally, four sizes of unfired hot water storage tanks with insulation are included.

\subsubsection{Incremental Cost Estimates}

ASHRAE incremental cost estimates are based on manufacturer responses to a commercial water heater survey conducted by GAMA. The survey included three levels of thermal efficiency and two levels of standby efficiency, combined for a total of 20 cost levels in five categories of equipment. Incremental cost estimates were made for only 14 levels. This information is presented in Table 4.2. 
Table 4.1. ASHRAE Water Heater Baseline Cost Estimates

\begin{tabular}{|l|l|c|c|c|c|c|}
\hline \multicolumn{1}{|c|}{ Category } & \multicolumn{1}{|c|}{ Capacity } & MFR “A" & MFR “B” & MFR “C” & MFR “D” & Average \\
\hline 75 -gal Storage & $120 \mathrm{kBtu} / \mathrm{hr}$ & $\$ 2,478$ & $\$ 7,785$ & $\$ 1,683$ & $\$ 2,625$ & $\$ 3,665$ \\
\hline 100 -gal Storage & $199 \mathrm{kBtu} / \mathrm{hr}$ & $\$ 3,323$ & $\$ 8,200$ & $\$ 2,142$ & $\$ 3,500$ & $\$ 4,291$ \\
\hline 100 -gal Storage & $360 \mathrm{kBtu} / \mathrm{hr}$ & $\$ 5,337$ & $\$ 9,712$ & $\$ 2,830$ & $\$ 5,000$ & $\$ 5,720$ \\
\hline 100 -gal Storage & $500 \mathrm{kBtu} / \mathrm{hr}$ & $\$ 12,722$ & $\$ 11,250$ & $\$ 3,947$ & $\$ 7,375$ & $\$ 8,824$ \\
\hline Instantaneous & $400 \mathrm{kBtu} / \mathrm{hr}$ & $\$ 4,402$ & $\$ 4,125$ & $\$ 2,897$ & $\$ 2,483$ & $\$ 3,477$ \\
\hline Instantaneous & $1000 \mathrm{kBtu} / \mathrm{hr}$ & $\$ 6,250$ & $\$ 6,000$ & $\$ 4,785$ & $\$ 4,806$ & $\$ 5,460$ \\
\hline Unfired Storage Tank & $120 \mathrm{gal}$ & $\$ 2,265$ & $\$ 2,500$ & $\$ 1,673$ & $\$ 1,250$ & $\$ 1,922$ \\
\hline Unfired Storage Tank & $200 \mathrm{gal}$ & $\$ 3,545$ & $\$ 3,125$ & $\$ 2,371$ & $\$ 3,750$ & $\$ 3,198$ \\
\hline Unfired Storage Tank & $500 \mathrm{gal}$ & $\$ 9,656$ & $\$ 4,187$ & $\$ 10,351$ & $\$ 7,937$ & $\$ 8,033$ \\
\hline Unfired Storage Tank & $1000 \mathrm{gal}$ & $\$ 17,808$ & $\$ 5,662$ & $\$ 16,025$ & $\$ 13,125$ & $\$ 13,155$ \\
\hline
\end{tabular}

\subsection{Boilers}

Baseline and incremental boiler cost estimates were made for gas-fired units only.

\subsubsection{Baseline Cost Estimates}

Baseline costs for commercial packaged boilers were developed from dealer quotes for both atmospheric and power burner cast-iron and steel boilers. Information was collected for 10 size categories in the range of $200 \mathrm{kBtu} / \mathrm{hr}$ up to $4,000 \mathrm{kBtu} / \mathrm{hr}$. No information was collected on copper or copper/ nickel alloy boilers. Baseline cost information is presented in Tables 4.3 through 4.6.

Baseline cost estimates were developed from these data for four size categories: 300 to $400 \mathrm{kBtu} / \mathrm{hr}, 400$ to $1,000 \mathrm{kBtu} / \mathrm{hr}, 1,000$ to $2,500 \mathrm{kBtu} / \mathrm{hr}$, and 2,500 to $4,000 \mathrm{kBtu} / \mathrm{hr}$. Only a small number of the costs listed in Tables 4.3 through 4.6 are actually used. The baseline cost for a 300- to $400-\mathrm{kBtu} / \mathrm{hr}$ hot water boiler was estimated from the average cost for $400-\mathrm{kBtu} / \mathrm{hr}$ atmospheric and power burner cast-iron boilers. Similarly, the other size categories were estimated from the average costs of power and atmospheric cast-iron boilers of 800-, 1500-, and 3,000-kBtu/hr sizes. These baseline costs were also used for the steam boiler analysis. None of the steel boiler cost data were used. 
Table 4.2. ASHRAE Water Heater Incremental Cost Estimates

\begin{tabular}{|c|c|c|c|c|}
\hline Water Heater Type & $\begin{array}{c}\text { Technology } \\
\text { Level }\end{array}$ & $\begin{array}{l}\text { Thermal } \\
\text { Efficiency }\end{array}$ & $\begin{array}{l}\text { Standby Loss } \\
\text { Requirement }\end{array}$ & $\begin{array}{c}\text { Cost } \\
\text { Increase }\end{array}$ \\
\hline \multirow[t]{3}{*}{$<155 \mathrm{kBtu} / \mathrm{hr}$} & 1 & $78 \%$ & $\leq 1.3+114 / \mathrm{Vol}$ & $3 \%$ \\
\hline & 2 & $80 \%$ & $\leq 1.3+114 / \mathrm{Vol}$. & $10 \%$ \\
\hline & 3 & $86 \%$ & $\leq 1.0+67 / \mathrm{Vol}$ & $60 \%$ \\
\hline \multirow[t]{3}{*}{$\geq 155 \mathrm{kBtu} / \mathrm{hr}$} & 1 & $78 \%$ & $\leq 1.3+95 / \mathrm{Vol}$ & $3 \%$ \\
\hline & 2 & $80 \%$ & $\leq 1.3+95 / \mathrm{Vol}$ & $10 \%$ \\
\hline & 3 & $86 \%$ & $\leq 1.0+67 /$ Vol & $70 \%$ \\
\hline \multirow{3}{*}{$\begin{array}{l}\geq 4000 \mathrm{Btu} / \mathrm{hr} / \mathrm{gal} \\
\text { Vol. }<10 \mathrm{gal}\end{array}$} & 1 & $80 \%$ & N/A & $0 \%$ \\
\hline & 2 & $83 \%$ & N/A & $24 \%$ \\
\hline & 3 & $86 \%$ & N/A & $85 \%$ \\
\hline \multirow{3}{*}{$\begin{array}{l}\geq 4000 \mathrm{Btu} / \mathrm{hr} / \mathrm{gal} \\
\text { Vol. } \geq 10 \mathrm{gal}\end{array}$} & 1 & $77 \%$ & $\leq 2.3+67 / \mathrm{Vol}$ & $3 \%$ \\
\hline & 2 & $80 \%$ & $\leq 2.3+67 / \mathrm{Vol}$ & $13 \%$ \\
\hline & 3 & $86 \%$ & $\leq 1.0+50 / \mathrm{Vol}$ & $81 \%$ \\
\hline \multirow[t]{2}{*}{ Unfired Storage Tank } & 1 & N/A & $<13.6 \mathrm{Btu} / \mathrm{hr} / \mathrm{ft}^{2}$ & $3 \%$ \\
\hline & 2 & N/A & $<6.5 \mathrm{Btu} / \mathrm{hr} / \mathrm{ft}^{2}$ & $10 \%$ \\
\hline
\end{tabular}

\subsubsection{Incremental Cost Estimates}

Incremental cost estimates for high-efficiency packaged boilers were supplied by GAMA in the form of curves of cost versus efficiency for four size categories and two types of boilers (steam and water). When analyzing life-cycle costs, ASHRAE assumed that baseline costs for hot water and steam boilers were roughly equivalent. To test this assumption, ASHRAE repeated life-cycle cost calculations with water boiler cost estimates increased by $10 \%$ to account for the slightly higher cost of steam boilers. Minimum life-cycle costs occurred at the same efficiency levels in both cases, so the assumption was deemed acceptable. Cost increments supplied by GAMA are presented in Tables 4.7 and 4.8. 
Table 4.3. ASHRAE Atmospheric Burner Cast-Iron Boiler Baseline Cost Estimates

\begin{tabular}{||c|c|c|c|c||}
\hline Capacity & MFR “A” & MFR “B” & MFR “C” & Average \\
\hline $200 \mathrm{kBtu} / \mathrm{hr}$ & $\$ 1,951$ & $\$ 2,025$ & $\$ 2,500$ & $\$ 2,159$ \\
\hline $400 \mathrm{kBtu} / \mathrm{hr}$ & $\$ 2,565$ & $\$ 3,200$ & $\$ 3,200$ & $\$ 2,988$ \\
\hline $600 \mathrm{kBtu} / \mathrm{hr}$ & $\$ 4,476$ & $\$ 4,100$ & $\$ 4,200$ & $\$ 4,259$ \\
\hline $800 \mathrm{kBtu} / \mathrm{hr}$ & $\$ 4,915$ & $\$ 5,000$ & $\$ 5,300$ & $\$ 5,072$ \\
\hline $1,000 \mathrm{kBtu} / \mathrm{hr}$ & $\$ 5,824$ & $\$ 6,100$ & N/A & $\$ 5,962$ \\
\hline $1,500 \mathrm{kBtu} / \mathrm{hr}$ & $\$ 7,713$ & $\$ 8,200$ & N/A & $\$ 7,957$ \\
\hline $2,000 \mathrm{kBtu} / \mathrm{hr}$ & $\$ 9,602$ & $\$ 10,000$ & N/A & $\$ 9,801$ \\
\hline $2,500 \mathrm{kBtu} / \mathrm{hr}$ & $\$ 11,463$ & $\$ 13,800$ & N/A & $\$ 12,632$ \\
\hline $3,000 \mathrm{kBtu} / \mathrm{hr}$ & $\$ 13,054$ & $\$ 16,600$ & N/A & $\$ 14,827$ \\
\hline $4,000 \mathrm{kBtu} / \mathrm{hr}$ & N/A & $\$ 19,200$ & N/A & $\$ 19,200$ \\
\hline
\end{tabular}

Table 4.4. ASHRAE Power Burner Cast-Iron Boiler Baseline Cost Estimates

\begin{tabular}{|r|r|r|r||}
\hline Capacity & MFR “A” & MFR “B” & Average \\
\hline $200 \mathrm{kBtu} / \mathrm{hr}$ & $\$ 1,603$ & $\$ 10,000$ & $\$ 5,802$ \\
\hline $400 \mathrm{kBtu} / \mathrm{hr}$ & $\$ 3,684$ & $\$ 10,400$ & $\$ 7,042$ \\
\hline $600 \mathrm{kBtu} / \mathrm{hr}$ & $\$ 4,670$ & $\$ 10,800$ & $\$ 7,735$ \\
\hline $800 \mathrm{kBtu} / \mathrm{hr}$ & $\$ 5,342$ & $\$ 11,000$ & $\$ 8,171$ \\
\hline $1,000 \mathrm{kBtu} / \mathrm{hr}$ & $\$ 6,434$ & $\$ 12,300$ & $\$ 9,367$ \\
\hline $1,500 \mathrm{kBtu} / \mathrm{hr}$ & $\$ 7,518$ & $\$ 13,600$ & $\$ 10,559$ \\
\hline $2,000 \mathrm{kBtu} / \mathrm{hr}$ & $\$ 10,063$ & $\$ 14,900$ & $\$ 12,482$ \\
\hline $2,500 \mathrm{kBtu} / \mathrm{hr}$ & $\$ 11,781$ & $\$ 16,200$ & $\$ 13,991$ \\
\hline $3,000 \mathrm{kBtu} / \mathrm{hr}$ & $\$ 13,121$ & $\$ 17,100$ & $\$ 15,111$ \\
\hline $4,000 \mathrm{kBtu} / \mathrm{hr}$ & $\$ 15,918$ & $\$ 17,500$ & $\$ 16,709$ \\
\hline
\end{tabular}


Table 4.5. ASHRAE Steel Water-Tube Boiler Baseline Cost Estimates

\begin{tabular}{||c|c|c|c|c|c||}
\hline Capacity & MFR “A” & MFR “B” & MFR “C” & MFR “D” & Average \\
\hline $200 \mathrm{kBtu} / \mathrm{hr}$ & N/A & N/A & N/A & $\$ 16,000$ & $\$ 16,000$ \\
\hline $400 \mathrm{kBtu} / \mathrm{hr}$ & $\$ 3,357$ & $\$ 4,676$ & $\$ 3,900$ & $\$ 16,500$ & $\$ 7,108$ \\
\hline $600 \mathrm{kBtu} / \mathrm{hr}$ & $\$ 5,571$ & $\$ 4,840$ & $\$ 4,250$ & $\$ 17,000$ & $\$ 7,915$ \\
\hline $800 \mathrm{kBtu} / \mathrm{hr}$ & $\$ 7,235$ & $\$ 5,521$ & $\$ 4,600$ & $\$ 17,500$ & $\$ 8,714$ \\
\hline $1,000 \mathrm{kBtu} / \mathrm{hr}$ & $\$ 7,682$ & $\$ 6,278$ & $\$ 5,100$ & $\$ 18,600$ & $\$ 9,415$ \\
\hline $1,500 \mathrm{kBtu} / \mathrm{hr}$ & $\$ 9,012$ & $\$ 7,282$ & $\$ 6,120$ & $\$ 19,400$ & $\$ 10,454$ \\
\hline $2,000 \mathrm{kBtu} / \mathrm{hr}$ & $\$ 10,936$ & $\$ 8,127$ & $\$ 7,510$ & $\$ 15,000$ & $\$ 10,393$ \\
\hline $2,500 \mathrm{kBtu} / \mathrm{hr}$ & $\$ 11,978$ & $\$ 9,623$ & $\$ 8,950$ & $\$ 16,000$ & $\$ 11,638$ \\
\hline $3,000 \mathrm{kBtu} / \mathrm{hr}$ & $\$ 15,559$ & $\$ 10,496$ & $\$ 10,300$ & $\$ 17,000$ & $\$ 13,339$ \\
\hline $4,000 \mathrm{kBtu} / \mathrm{hr}$ & $\$ 18,907$ & $\$ 12,565$ & $\$ 13,400$ & $\$ 18,000$ & $\$ 15,718$ \\
\hline
\end{tabular}

Table 4.6. ASHRAE Steel Fire-Tube and Scotch Marine Boiler Baseline Cost Estimates

\begin{tabular}{||c|c|c|c|c|c||}
\hline Capacity & MFR “A” & MFR “B” & MFR “C” & MFR “D” & Average \\
\hline $200 \mathrm{kBtu} / \mathrm{hr}$ & N/A & $\$ 7,684$ & N/A & $\$ 16,000$ & $\$ 11,842$ \\
\hline $400 \mathrm{kBtu} / \mathrm{hr}$ & $\$ 7,026$ & $\$ 7,684$ & N/A & $\$ 16,500$ & $\$ 10,403$ \\
\hline $600 \mathrm{kBtu} / \mathrm{hr}$ & $\$ 7,191$ & $\$ 9,170$ & $\$ 6,100$ & $\$ 17,300$ & $\$ 9,940$ \\
\hline $800 \mathrm{kBtu} / \mathrm{hr}$ & $\$ 7,344$ & $\$ 9,431$ & $\$ 6,800$ & $\$ 18,100$ & $\$ 10,419$ \\
\hline $1,000 \mathrm{kBtu} / \mathrm{hr}$ & N/A & $\$ 9,618$ & $\$ 6,800$ & $\$ 18,900$ & $\$ 11,839$ \\
\hline $1,500 \mathrm{kBtu} / \mathrm{hr}$ & $\$ 8,782$ & $\$ 11,714$ & $\$ 8,360$ & $\$ 22,200$ & $\$ 12,764$ \\
\hline $2,000 \mathrm{kBtu} / \mathrm{hr}$ & $\$ 10,132$ & $\$ 13,514$ & $\$ 10,265$ & $\$ 24,200$ & $\$ 14,438$ \\
\hline $2,500 \mathrm{kBtu} / \mathrm{hr}$ & N/A & N/A & $\$ 11,670$ & $\$ 27,800$ & $\$ 19,735$ \\
\hline $3,000 \mathrm{kBtu} / \mathrm{hr}$ & $\$ 13,994$ & $\$ 17,466$ & $\$ 12,500$ & $\$ 30,000$ & $\$ 18,490$ \\
\hline $4,000 \mathrm{kBtu} / \mathrm{hr}$ & $\$ 17,681$ & $\$ 18,937$ & $\$ 19,170$ & $\$ 34,000$ & $\$ 22,447$ \\
\hline
\end{tabular}


Table 4.7. ASHRAE Hot Water Boiler Incremental Cost Estimates

\begin{tabular}{|c|c|c|c|c|}
\hline $\begin{array}{c}\text { Thermal } \\
\text { Efficiency }\end{array}$ & $\begin{array}{c}\mathbf{3 0 0} \text { to } \mathbf{4 0 0} \\
\mathbf{k B t u} / \mathbf{h r}\end{array}$ & $\begin{array}{c}\mathbf{4 0 0} \text { to } \mathbf{1 , 0 0 0} \\
\mathbf{k B t u} / \mathbf{h r}\end{array}$ & $\begin{array}{c}\mathbf{1 , 0 0 0} \text { to } \mathbf{2 , 5 0 0} \\
\mathbf{k B t u} / \mathbf{h r}\end{array}$ & $\begin{array}{c}\mathbf{2 , 5 0 0} \text { to 4,000 } \\
\mathbf{k B t u} / \mathbf{h r}\end{array}$ \\
\hline $75 \%$ & $0 \%$ & $0 \%$ & $0 \%$ & $0 \%$ \\
\hline $75 \%$ & $6 \%$ & - & - & - \\
\hline $76 \%$ & $10 \%$ & $10 \%$ & $10 \%$ & $10 \%$ \\
\hline $77 \%$ & $15 \%$ & $35 \%$ & $40 \%$ & $15 \%$ \\
\hline $78 \%$ & $22 \%$ & $35 \%$ & $40 \%$ & $15 \%$ \\
\hline $79 \%$ & $44 \%$ & $90 \%$ & $110 \%$ & $30 \%$ \\
\hline $80 \%$ & $114 \%$ & $90 \%$ & $110 \%$ & $40 \%$. \\
\hline $82 \%$ & $121 \%$ & $210 \%$ & $255 \%$ & $73 \%$ \\
\hline $84 \%$ & $261 \%$ & $210 \%$ & $255 \%$ & $100 \%$ \\
\hline $88 \%$ & $450 \%$ & $450 \%$ & $350 \%$ & $300 \%$ \\
\hline
\end{tabular}

The first level of incremental costs for the 300 to $400 \mathrm{kBtu} / \mathrm{hr}$ size category represents a change from pilot to electronic ignition, not affecting the combustion efficiency. The pilot is assumed to use energy at a rate of $1,000 \mathrm{Btu} / \mathrm{hr}$.

\subsection{Warm Air Furnaces}

The cost estimates for ASHRAE warm air furnaces are based on outdoor gas-fired models. Warm air furnaces for indoor installation are covered by EPAct but were not considered in the ASHRAE analysis.

\subsubsection{Baseline Cost Estimates}

Information on the cost of baseline equipment was developed by a consultant. A summary of this information is provided in Table 4.9. This represents the cost for stripped-down units with no accessories, such as economizers and curbs. ASHRAE subsequently revised the cost for the $250 \mathrm{kBtu} / \mathrm{hr}$ unit upward by $5 \%$ to an average cost of $\$ 5,133$. This estimate was used in the analysis. 
Table 4.8. ASHRAE Steam Boiler Incremental Cost Estimates

\begin{tabular}{|c|c|c|c|c||}
\hline $\begin{array}{c}\text { Thermal } \\
\text { Efficiency }\end{array}$ & $\begin{array}{c}300 \text { to } 400 \\
\mathbf{k B t u} / \mathbf{h r}\end{array}$ & $\begin{array}{c}\mathbf{4 0 0} \text { to } \mathbf{1 , 0 0 0} \\
\mathbf{k B t u} / \mathbf{h r}\end{array}$ & $\begin{array}{c}\mathbf{1 , 0 0 0} \text { to 2,500 } \\
\mathbf{k B t u} / \mathbf{h r}\end{array}$ & $\begin{array}{c}\mathbf{2 , 5 0 0} \text { to 4,000 } \\
\mathbf{k B t u} / \mathbf{h r}\end{array}$ \\
\hline $72 \%$ & $0 \%$ & $0 \%$ & $0 \%$ & $0 \%$ \\
\hline $72 \%$ & $5 \%$ & - & - & - \\
\hline $73 \%$ & $10 \%$ & $10 \%$ & $10 \%$ & $10 \%$ \\
\hline $74 \%$ & $10 \%$ & $10 \%$ & $10 \%$ & $10 \%$ \\
\hline $75 \%$ & $10 \%$ & $10 \%$ & $10 \%$ & $10 \%$ \\
\hline $76 \%$ & $26 \%$ & $35 \%$ & $40 \%$ & $10 \%$ \\
\hline $77 \%$ & $47 \%$ & $45 \%$ & $50 \%$ & $15 \%$ \\
\hline $78 \%$ & $50 \%$ & $45 \%$ & $50 \%$ & $15 \%$ \\
\hline $79 \%$ & $52 \%$ & $45 \%$ & $50 \%$ & $30 \%$ \\
\hline $80 \%$ & $100 \%$ & $60 \%$ & $60 \%$ & $60 \%$ \\
\hline $81 \%$ & $114 \%$ & $125 \%$ & $125 \%$ & - \\
\hline
\end{tabular}

Table 4.9. ASHRAE Outdoor Furnace Baseline Cost Estimates

\begin{tabular}{|r|c|c|r|r|r||}
\hline Furnace Size & MFR “A” & MFR “B” & MFR “C” & MFR “D” & Average \\
\hline $250 \mathrm{kBtu} / \mathrm{hr}$ & $\$ 4,932$ & $\$ 4,875$ & $\$ 5,000$ & $\$ 4,750$ & $\$ 4,889$ \\
\hline $400 \mathrm{kBtu} / \mathrm{hr}$ & $\$ 6,702$ & $\$ 6,250$ & $\$ 7,875$ & $\$ 7,500$ & $\$ 7,082$ \\
\hline $1,000 \mathrm{kBtu} / \mathrm{hr}$ & $\$ 22,700$ & $\$ 19,750$ & $\$ 27,500$ & $\$ 27,000$ & $\$ 24,236$ \\
\hline
\end{tabular}

\subsubsection{Incremental Cost Estimates}

Incremental cost estimates for high-efficiency outdoor gas furnaces were provided by GAMA, based on manufacturer responses to a warm air furnace survey. Each efficiency level is associated with a specific burner type and ignition system. These estimates are presented in Table 4.10. 
Table 4.10. ASHRAE Outdoor Furnace Incremental Cost Estimates

\begin{tabular}{||l|c|c|c|c|c||}
\hline \multicolumn{1}{|c|}{ Burner Type } & $\begin{array}{c}\text { Combustion } \\
\text { Efficiency }\end{array}$ & $\begin{array}{c}\text { Ignition } \\
\text { System }\end{array}$ & $\mathbf{2 5 0} \mathbf{~ k B t u} / \mathbf{h r}$ & $\mathbf{4 0 0} \mathbf{~ k B t u / h r}$ & $\mathbf{1 0 0 0} \mathbf{~ k B t u} / \mathbf{h r}$ \\
\hline Atmospheric & $78 \%$ & Pilot & $0.0 \%$ & $0.0 \%$ & $0.0 \%$ \\
\hline Atmospheric & $80 \%$ & IID $^{(a)}$ & $1.5 \%$ & $1.5 \%$ & $1.5 \%$ \\
\hline Atmospheric, Vent Cap & $80 \%$ & IID $^{(a)}$ & $3.5 \%$ & $3.5 \%$ & $4.5 \%$ \\
\hline Power & $80 \%$ & IID $^{(a)}$ & $6.0 \%$ & $6.0 \%$ & $6.0 \%$ \\
\hline Power & $82 \%$ & IID $^{(a)}$ & $7.0 \%$ & $6.0 \%$ & $7.0 \%$ \\
\hline Power, Condensing & $88 \%$ & IID $^{(a)}$ & $50.0 \%$ & $51.0 \%$ & $55.0 \%$ \\
\hline (a) IID = Intermittent Ignition Device. & & & \\
\hline \hline
\end{tabular}




\subsection{Database Description}

The equipment database in Appendix A includes six tables containing data on equipment with similar characteristics. To protect the confidentiality of the cost information, all manufacturer-specific data were excluded. In addition, some cost information was deleted where equipment characteristics were unique to a particular manufacturer. The remaining fields include descripters of the equipment and its characteristics that affect cost. The following sections describe the tables and the data that they contain.

\subsection{Common Variables}

Four common variables exist in each table of the database: record number (REC), cost type (CTYPE), list cost (LCOST), and estimated contractor cost (CCOST). List costs were provided by manufacturers, usually in the form of published price sheets. These price sheets represent either a retail list price, which reflects retail pricing, or a distributor list price, which reflects distributor pricing. Neither price measures actual average retail or distributor costs for the equipment. Instead they are used as a basis for actual pricing, using some percentage discount or markup.

The published list prices are included in the equipment database, along with a price-type descripter (CTYPE) (either retail [R] or distributor [D]). This variable measures the approximate level of the list price. Another cost measure, CCOST, is used to represent the estimated contractor price for the equipment. Where possible, CCOST was developed from list cost on the basis of manufacturer-supplied estimates of the wholesale discount from list price. An additional 10\% is added to estimated wholesale price to account for dealer markup. Some manufacturers offer a discount off of list price in a complicated fashion, making estimates of the wholesale price from the list price difficult to calculate. When no estimate of the list price average discount was available, equipment dealers were contacted for contractor pricing. Average contractor costs were then used to arrive at a multiplier to estimate contractor costs from the list price. The variable CCOST is used in the statistical analysis.

The values of CCOST must also be modified to arrive at consumer cost. Commercial equipment is typically purchased by a contractor who then charges some markup in addition to the purchase price. This markup does not reflect labor costs for installing the equipment but instead covers overhead and profit. Contractor markup may vary from less than $15 \%$ to more than $50 \%$ depending on the characteristics of the job. Because a precise method for evaluating average contractor markups for commercial equipment does not exist, a midrange value of $25 \%$ was used. This estimate is consistent with the contractor markup that is used by ASHRAE. Costs developed from the statistical models presented below must be marked up by $25 \%$ to arrive at estimated consumer cost. The remaining database variables are described below. 


\subsection{Water Heaters}

Water-heating equipment is separated into four different categories: fuel-fired storage water heaters, tankless water heaters, electric storage water heaters, and unfired hot water storage tanks.

\subsubsection{Fuel-Fired Storage Water Heaters}

FUEL is a character variable that describes the fuel type used by the equipment, either gas (G) or oil $(\mathrm{O})$.

VOL is a numerical variable that describes the water heater tank volume in gallons. This is the nominal volumetric capacity of the water heater, as reported by the manufacturer. Nominal volume typically varies from actual volume by up to $3 \%$ but is the more commonly available measure.

INPUT is a numerical variable that describes the fuel input capacity in $\mathrm{kBtu} / \mathrm{hr}$, as reported by the manufacturer.

EFF is a numerical variable that describes the thermal efficiency of the water heater defined by ANSI Standard Z21.10.3 (AGA 1993). Where possible, this information is taken from the California Energy Commission (CEC) equipment database. Manufacturer-provided information is used to supplement the CEC data when actual test results are available.

STBY is a numerical variable that describes the standby loss rating of the water heater in percent per hour, based on ANSI Standard Z21.10.3. Where possible, this information is taken from the CEC equipment database. Manufacturer-provided information is used to supplement the CEC data when actual test results are available.

TANK is a character variable that describes the tank construction, either standard (S) or American Society of Mechanical Engineering (ASME) code (A), as provided by the manufacturer.

BURN is a character variable that describes the burner type, either atmospheric (A) or power (P), taken from the CEC database or manufacturer literature.

WARR is a numerical variable that indicates the length (in years) of the manufacturer warranty on the equipment.

\subsubsection{Tankless Water Heaters}

FUEL is a character variable that describes the fuel type used by the equipment, either gas $(\mathrm{G})$ or oil (O).

INPUT is a numerical variable that describes the fuel input capacity in $\mathrm{kBtu} / \mathrm{hr}$, as reported by the manufacturer. 
EFF is a numerical variable that describes the thermal efficiency of the water heater, defined by ANSI Standard Z21.10.3. Where possible, this information is taken from the CEC equipment database. Manufacturer-provided information is used to supplement the CEC data when actual test results are available.

EXCH ia a character variable that describes the heat exchanger material type (steel [S], cast iron [I], copper [C], or copper-nickel alloy [N]). One line of water heaters of the direct contact type has $\mathrm{EXCH}=\mathrm{D}$ to identify it from other conventional models. Heat exchange actually occurs in a stainless steel mesh material.

WARR is a numerical variable that indicates the length (in years) of the manufacturer warranty on the equipment.

\subsubsection{Electric Storage Water Heaters}

VOL is a numerical variable that describes the water heater tank volume in gallons. This is the nominal volumetric capacity of the water heater, as reported by the manufacturer. Nominal volume typically varies from actual volume by up to $3 \%$ but is the more commonly available measure.

INP is a numerical variable that describes the energy input capacity in kilowatts, as reported by the manufacturer.

STBY is a numerical variable that describes the standby loss rating of the water heater in percent per hour. Where possible, this information is taken from the CEC equipment database. Manufacturerprovided information is used to supplement the CEC data when actual test results are available.

VOLT is a numerical variable that indicates the supply voltage for the equipment, as provided by the manufacturer.

TANK is a character variable that describes the tank construction, either standard (S) or ASME code (A), as provided by the manufacturer.

RVAL is a numerical variable that describes the R-value of insulation on the water heater, as provided by the manufacturer or estimated from the insulation thickness and type.

WARR is a numerical variable that indicates the length (in years) of the manufacturer warranty on the equipment.

THERM is a character variable that indicates the thermostat type, either immersion (I) or surface $(S)$. 


\subsubsection{Unfired Hot Water Storage Tanks}

VOL is a numerical variable that describes the storage tank volume in gallons. This is the nominal volumetric capacity of the storage tank, as reported by the manufacturer. Nominal volume typically varies from actual volume by up to $3 \%$ but is the more commonly available measure.

RVAL is numerical variable that describes the R-value of insulation on the tank, as provided by the manufacturer or estimated from the insulation thickness and type.

TANK is a character variable that describes the tank construction, either standard (S) or ASME code (A), as provided by the manufacturer.

LIN is a character variable that describes the material used to line the water tank (glass [G], epoxy $[\mathrm{E}]$, cement or stone $[\mathrm{S}]$, or nickel $[\mathrm{N}]$ ), as provided by the manufacturer.

ORIENT is a character variable that describes the tank orientation, either vertical (V) or horizontal $(\mathrm{H})$, as provided by the manufacturer.

PRESS is a numerical variable that describes the pressure rating of the storage tank (in psig) as provided by the manufacturer.

WARR is a numerical variable that indicates the length (in years) of the manufacturer warranty on the equipment.

\subsection{Packaged Boilers}

TYPE is a character variable for the boiler type, either steam (S) or water (W).

FUEL is a character variable that describes the fuel type used by the equipment, either gas $(\mathrm{G})$ or oil $(\mathrm{O})$.

INPUT is a numerical variable that describes the fuel input capacity in $\mathrm{kBtu} / \mathrm{hr}$, as reported by the manufacturer.

EFF is a numerical variable that describes the combustion efficiency of the furnace, defined as $100 \%$ minus flue losses. Where possible, this information is taken from the CEC equipment database. Manufacturer-provided information is used to supplement the CEC data when actual test results are available.

EXCH is a character variable that describes the heat exchanger type (copper [C], copper-nickel alloy $[\mathrm{N}]$, cast-iron [I], or steel [S]), as provided by the manufacturer.

IGN is a character variable that describes the ignition type, either electronic (E) or pilot $(\mathrm{P})$. 
BURN is a character variable that describes the burner type (power $[\mathrm{P}]$, atmospheric $[\mathrm{A}]$, or pulse [L]).

VENT is a character variable that describes whether the unit has a vent damper $(\mathrm{Y})$ or does not $(\mathrm{N})$.

\subsection{Warm Air Furnaces}

FUEL is a character variable that describes the fuel type used by the equipment, either gas (G) or oil (O).

INPUT is a numerical variable that describes the fuel input capacity in $\mathrm{kBtu} / \mathrm{hr}$, as reported by the manufacturer.

EFF is a numerical variable that describes the thermal efficiency of the furnace, defined as $100 \%$ minus flue losses. Where possible, this information is taken from the CEC equipment database.

Manufacturer-provided information is used to supplement the CEC data when actual test results are available. 


\subsection{Estimate of Baseline Consumer Costs}

The consumer cost for commercial equipment is assumed to be the price paid by the consumer to a contractor for the equipment, not including installation. As discussed previously, estimating contractor markup for equipment is difficult because it varies as a function of the customer, the job size, and other factors. The baseline cost estimates that ASHRAE uses for equipment are developed from contractor cost estimates and an estimated $25 \%$ contractor markup, not including labor. This estimate is consistent with reported values and is used in this report. The statistical models are reported in terms of contractor costs, and they are multiplied by 1.25 to arrive at estimated consumer cost.

\subsection{Water Heaters}

Water heater information was provided by 16 manufacturers. The database includes more than 1,500 individual water heater records, which are divided into four categories: fuel-fired water heaters, fuel-fired tankless water heaters, electric storage water heaters, and unfired hot water storage tanks.

\subsubsection{Fuel-Fired Storage Water Heaters}

Fuel-fired storage water heaters include three subcategories of equipment: models with input ratings $\leq 155,000 \mathrm{Btu} / \mathrm{hr}$, models with input ratings $>155,000 \mathrm{Btu} / \mathrm{hr}$ and an input-to-storage volume ratio less than $4,000 \mathrm{Btu} / \mathrm{hr}$, and models with input ratings $>155,000 \mathrm{Btu} / \mathrm{hr}$ and an input-to-storage volume ratio of $4,000 \mathrm{Btu} / \mathrm{hr} /$ gallon or more (labeled instantaneous in ASHRAE definitions). The lower input bound for commercial models is also divided by fuel type: $105,000 \mathrm{Btu} / \mathrm{hr}$ for oil-fired storage models and 75,000 Btu/hr for gas-fired storage models. The lower bound for instantaneous models is $210,000 \mathrm{Btu} / \mathrm{hr}$ for oil-fired units and $200,000 \mathrm{Btu} / \mathrm{hr}$ for gas-fired units. These categories are summarized in Table 6.1. This categorization results in the anomaly that a $160,000 \mathrm{Btu} / \mathrm{hr}$ water heater is classified as a residential instantaneous water heater if the tank volume is less than $40 \mathrm{gal}$, or a commercial storage water heater if the tank volume is greater than or equal to 40 gal.

Despite the complexity of this subcategorization, fuel-fired water heaters with storage tanks are a fairly homogenous product. The designation of instantaneous water heaters with greater than 10-gallon storage capacity attempts to capture the effect on standby losses of increased flue area at high-input-tovolume ratios; however, units falling just below and above $4,000 \mathrm{Btu} / \mathrm{hr}$ input-to-volume ratio are very similar. The separate designation of units above and below $155,000 \mathrm{Btu} / \mathrm{hr}$ input also is directed at capturing differences in standby loss performance, as reflected in the standard. 
Table 6.1. Fuel-Fired Storage Water Heater Categories

\begin{tabular}{||l|l|l|l|l||}
\hline \multicolumn{1}{|c|}{ Type } & \multicolumn{1}{|c|}{ Input Rating } & \multicolumn{1}{c|}{ Volume } & $\begin{array}{c}\text { Input-to-Volume } \\
\text { Ratio }\end{array}$ & \multicolumn{1}{c||}{ Standard } \\
\hline Storage Gas & $>75$ and $\leq 155 \mathrm{kBtu} / \mathrm{hr}$ & All & All & $\begin{array}{l}78 \% \text { efficiency } \\
1.3+114 / \mathrm{Vol} .\end{array}$ \\
\hline Storage Oil & $>105 \mathrm{and} \leq 155 \mathrm{kBtu} / \mathrm{hr}$ & All & All & $\begin{array}{l}78 \% \text { efficiency } \\
1.3+114 / \mathrm{Vol} .\end{array}$ \\
\hline Storage & $>155 \mathrm{kBtu} / \mathrm{hr}$ & $\geq 10 \mathrm{gal}$ & $<4,000 \mathrm{Btu} / \mathrm{hr}$ & $\begin{array}{l}78 \% \text { efficiency } \\
1.3+95 / \mathrm{Vol} .\end{array}$ \\
\hline Tankless Gas & $>200 \mathrm{kBtu} / \mathrm{hr}$ & $<10 \mathrm{gal}$ & $\geq 4,000 \mathrm{Btu} / \mathrm{hr}$ & $\begin{array}{l}77 \% \text { efficiency } \\
2.3+67 / \mathrm{Vol} .\end{array}$ \\
\hline Tankless Oil & $>210 \mathrm{kBtu} / \mathrm{hr}$ & $<10 \mathrm{gal}$ & $\geq 4,000 \mathrm{Btu} / \mathrm{hr}$ & $\begin{array}{l}77 \% \text { efficiency } \\
2.3+67 / \mathrm{Vol} .\end{array}$ \\
\hline
\end{tabular}

These trends in performance are verified by testing for differences in efficiency and standby losses between equipment subcategories. As expected, no significant differences exist in thermal efficiency between any of the size categories. However, standby losses are significantly lower for large-input storage water heaters (input/volume $<4,000 \mathrm{Btu} / \mathrm{hr} / \mathrm{gal}$ ) than for instantaneous water heaters that fall in the same size range. This is reflected in the standard, which is less restrictive for water heaters that are classified as instantaneous.

Baseline costs for these equipment categories were modeled as a function of the primary characteristics of the equipment: input, warranty, tank construction, and efficiency. Information was provided by seven manufacturers of storage water heaters totaling 295 units. The database contains information for 33 units with input of $155,000 \mathrm{Btu} / \mathrm{hr}$ or less, all of which are gas-fired. Four of these units were not used in the model because the records were incomplete. The remaining 29 units were used to develop the model (R-squared $=0.99$ ), which is given below, with t-statistics for each parameter given in parenthesis.

$$
\begin{aligned}
& \mathrm{CCOST}=14.6 * \mathrm{INPUT}+121.6 * \mathrm{WARR}+22.1 * \mathrm{EFF}+5,895 * \text { OUT }-2,317 \\
& \begin{array}{lllll}
(0.0001) & (0.0028) & (0.0046) & (0.0001) & (0.0013)
\end{array}
\end{aligned}
$$

where INPUT is in $\mathrm{kBtu} / \mathrm{hr}$, WARR is the length of the warranty (usually 3 or 5 years), EFF is efficiency as a whole number $(88 \%=88)$, and OUT is a dummy variable used to account for several large-volume water heaters (OUT $=1$ if Vol. $\geq 140$ gal, otherwise OUT $=0$ ) included in the database for which the model otherwise underpredicts costs. CCOST was not significantly correlated with tank volume at the 5\% level. No ASME construction tanks were included in the database for this size range. 
Only one unit in this size range is considered in the ASHRAE analysis. ASHRAE and modeled baseline cost estimates are compared in Table 6.2. The baseline efficiency is assumed to be $78 \%$, the warranty, 3 years, and the outlier dummy variable is set to 0 .

Modeled baseline costs are only about half of ASHRAE estimates, primarily because of one extremely high cost estimate for this category of water heater (Table 4.1). While the cost of this unit is more in line with costs for large-volume equipment represented by the OUT dummy variable, the ASHRAE analysis was based on a 75-gallon unit and thus does not account for the discrepancy.

Units above $155,000 \mathrm{Btu} / \mathrm{hr}$ were modeled as two groups to account for these same large-volume water heaters ( $>140$ gallons). In both cases, CCOST was not found to be significantly correlated with efficiency. A total of 176 units were used to develop the model for the small-volume units $(\mathrm{R}$-squared $=0.96)$. The model is given below.

$$
\begin{array}{ccc}
\mathrm{CCOST}= & 5.80 * \mathrm{INPUT} \\
(0.0001) & 129 * \text { WARR } & +486 * \mathrm{TANK}+910 * \mathrm{BURN}+468 \\
(0.0001) & (0.0001) & (0.0001)
\end{array}
$$

where INPUT is in $\mathrm{kBtu} / \mathrm{hr}$, WARR is the length of the warranty in years, TANK is an indicator variable for the type of tank construction (TANK $=1$ if ASME; 0 if standard), and BURN is an indicator variable for power burners (BURN $=1$ if power, 0 if atmospheric). Because oil-fired equipment is under-represented in the database, oil-fired units were excluded from the analysis. The model is thus valid for gas-fired equipment and can be used for comparison to ASHRAE-developed cost estimates. A comparison of ASHRAE and modeled cost estimates is given in Table 6.3, where the warranty is 3 years and BURN $=0$ for the standard models and BURN $=1$ for ASME models.

Table 6.2. Comparison of ASHRAE and Modeled Baseline Cost Estimates for Low-Input Fuel-Fired Storage Water Heaters

\begin{tabular}{|c|c|c|c|}
\hline Size & ASHRAE & Model & Difference \\
\hline $120 \mathrm{kBtu} / \mathrm{hr}$ & $\$ 3,665$ & $\$ 1,900$ & $-48 \%$ \\
\hline
\end{tabular}

Table 6.3. Comparison of ASHRAE and Modeled Baseline Cost Estimates for High-Input Fuel-Fired Storage Water Heaters

\begin{tabular}{|c|c|c|c||}
\hline Input & ASHRAE & $\begin{array}{c}\text { Model } \\
\text { (Standard) }\end{array}$ & $\begin{array}{c}\text { Model } \\
\text { (ASME) }\end{array}$ \\
\hline $199 \mathrm{kBtu} / \mathrm{hr}$ & $\$ 4,291$ & $\$ 2,512$ & $\$ 4,257$ \\
\hline $360 \mathrm{kBtu} / \mathrm{hr}$ & $\$ 5,720$ & $\$ 3,679$ & $\$ 5,424$ \\
\hline $500 \mathrm{kBtu} / \mathrm{hr}$ & $\$ 8,824$ & $\$ 4,693$ & $\$ 6,438$ \\
\hline
\end{tabular}


ASHRAE cost estimates for the $199,000 \mathrm{Btu} / \mathrm{hr}$ and the $360,000 \mathrm{Btu} / \mathrm{hr}$ units are at the high end of modeled cost estimates. For the $500,000 \mathrm{Btu} / \mathrm{hr}$ unit, ASHRAE cost estimates are much higher than modeled cost estimates. Several large-volume models (140 or more gallons) were left out of the data set in developing this model. These units, a total of 38 , can be modeled separately to account for the equipment. The resulting model $(\mathrm{R}$-squared $=0.85)$ is given below.

$$
\begin{gathered}
\text { CCOST }=2.81 * \text { INPUT }+29.9 * \text { VOL }+5,358 \\
(0.0008) \\
(0.0001)
\end{gathered}
$$

where INPUT is in $\mathrm{kBtu} / \mathrm{hr}$ and VOL is the volume in gallons. Because the ASHRAE analysis does not include any equipment with greater than 100-gal storage capacity, this model was not used for comparison with ASHRAE results. As before, the model was developed using only data from gas-fired units.

\subsubsection{Tankless Water Heaters}

Low-volume instantaneous (tankless) water heaters are designated in ASHRAE 90.1-1989 as water heaters having an input-to-volume ratio of $4,000 \mathrm{Btu} / \mathrm{gal} / \mathrm{hr}$ or more, less than $10 \mathrm{gal}$ of water storage volume, and inputs $>200,000 \mathrm{Btu} / \mathrm{hr}$ for gas-fired units and inputs greater than $210,000 \mathrm{Btu} / \mathrm{hr}$ for oilfired units. Five manufacturers of gas fired equipment provided data. Several manufacturers of oilfired boilers offer options that allow them to be used as tankless water heaters. However, because these units are marketed as boilers, and because the ASHRAE analysis does not consider oil-fired equipment in this category, they were not evaluated.

Input ratings for gas-fired equipment range from $225,000 \mathrm{Btu} / \mathrm{hr}$ to $21,000,000 \mathrm{Btu} / \mathrm{hr}$. Performance data for all 108 units were available from the CEC equipment database. The majority of the units fall in the combustion-efficiency range of 80 to $82 \%$ and are of copper finned-tube design. Highperformance copper finned-tube units range to higher than $88 \%$ efficiency. One company manufactures a single modulating-input condensing model, which achieves efficiencies from $93 \%$ to $99 \%$ as input ranges from maximum-rated capacity to a 10:1 turndown ratio. A complete line of high-input direct-contact models also exist, reaching $99 \%$ efficiency. In this design, the cold inlet water comes in direct contact with the hot products of combustion, allowing virtually all of the thermal energy to be transferred to the water.

Using the efficiency at maximum-rated input for the modulating condensing unit (93\%), regression analysis using all of the data yields a cost model of input and efficiency with a very high R-squared value (0.99). This may not be the best model for estimating equipment costs for two reasons. First, the ASHRAE analysis is limited to consideration of efficiencies from $80 \%$ to $86 \%$, so including highefficiency models may diminish the validity at lower efficiencies. Second, the direct-contact models are very large ( 1 to 21 million $B t u / h r$ ), so they do not represent typical units in the $80 \%$ to $86 \%$ efficiency range. 
Regression analysis of CCOST using only units with $93 \%$ efficiency or less (96 units) suggests models with input and efficiency as the explanatory variables. Evaluating residual plots reveals that a straight line model cannot account for the incremental cost of high-efficiency equipment. Introducing a squared term on efficiency improves the $R$-squared value from 0.81 to 0.90 . The model below is used to estimate cost.

$$
\begin{gathered}
\mathrm{CCOST}=2.35 * \mathrm{INPUT}-7,872 * \mathrm{EFF}+49.5 * \mathrm{EFF}^{2}+314,743 \\
(0.0001) \\
(0.0001)
\end{gathered}
$$

where INPUT is in $\mathrm{kBtu} / \mathrm{hr}$ and EFF is efficiency as a whole number $(88 \%=88)$. The ASHRAE analysis is based on two sizes of equipment $(400 \mathrm{kBtu} / \mathrm{hr}$ and $1,000 \mathrm{kBtu} / \mathrm{hr})$ and an estimated baseline efficiency of $80 \%$. Model and ASHRAE estimates are presented in Table 6.4.

Table 6.4. Comparison of ASHRAE and Modeled Baseline Cost Estimates for Tankless Water Heaters

\begin{tabular}{|c|c|c|c|}
\hline Size & ASHRAE & Model & Difference \\
\hline $400 \mathrm{kBtu}$ & $\$ 3,477$ & $\$ 3,291$ & $-5.3 \%$ \\
\hline $1000 \mathrm{kBtu}$ & $\$ 5,460$ & $\$ 5,058$ & $-7.4 \%$ \\
\hline
\end{tabular}

When evaluating the life-cycle cost for this equipment, ASHRAE only used the $400 \mathrm{kBtu} / \mathrm{hr}$ model. Thus, modeled costs are 5.3\% lower than ASHRAE-developed costs.

\subsubsection{Electric Storage Water Heaters}

Electric storage water heaters make up less than $20 \%$ of commercial water heater shipments according to data covering the first 7 months of 1994 (Appliance Manufacturer 1994, p. 15). At this time, ASHRAE has not evaluated the life-cycle costs for baseline and high-efficiency electric storage water heaters. Data for electric storage water heaters are included in the database, so a model was developed for this equipment.

The database contains about 1,000 records for electric storage units produced by nine companies, with tank volumes ranging from 50 to 1,000 gallons and input ratings ranging from 13.5 to $480 \mathrm{~kW}$. When the data were analyzed, it was found that no simple model adequately characterized costs in the different size classes. Instead, separate models were developed for common size classes; in this case, 50,80 , and $120 \mathrm{gal}$ of storage volume. These units have a vertical cylindrical configuration and are similar to residential electric water heaters, but they have a heavier construction. Costs were also found to be a function of the number of thermostats and fuses used in the heater. Because this number typically varies as a function of input size classes, the effect can be captured by further segregating the 
heaters into three input categories: less than $20 \mathrm{~kW}$, between 20 and $40 \mathrm{~kW}$, and above $40 \mathrm{~kW}$. These categories will be referred to in this report as class 1,2 , and 3 , respectively (input alone did not capture these effects). The resulting models are presented below.

$$
\begin{aligned}
& \operatorname{Cost}(50)=365+400 * \text { THERM }+338 * \text { TANK }+175^{*} \text { WARR }+481 * \mathrm{C} 2+1075 * \mathrm{C} 3 \\
& \begin{array}{llllll}
(0.001) & (0.0001) & (0.0001) & (0.0001) & (0.0001) & (0.0001)
\end{array} \\
& \operatorname{Cost}(80)=628+446 * \text { THERM }+366 * \text { TANK }+164 * \text { WARR }+488 * \mathrm{C} 2+1057 * \mathrm{C} 3 \\
& \begin{array}{llllll}
(0.0001) & (0.0001) & (0.0001) & (0.0001) & (0.0001) & (0.0001)
\end{array} \\
& \operatorname{Cost}(120)=877+485 * \text { THERM }+371 * \text { TANK }+162 * \text { WARR }+392 * \mathrm{C} 2+1002 * \mathrm{C} 3 \\
& \begin{array}{llllll}
(0.0001) & (0.0001) & (0.0001) & (0.0001) & (0.0001) & (0.0001)
\end{array}
\end{aligned}
$$

where THERM is a dummy variable for the thermostat type (surface $=0$, immersion $=1$ ), TANK is a dummy variable for tank construction (standard $=0, A S M E=1$ ), WARR is the length of the warranty in years, C2 is a dummy variable for class 2 ( 1 if the input rating is between 20 and $40 \mathrm{~kW}$ ), and C3 is a dummy variable for class 3 ( 1 if the input rating is above $40 \mathrm{~kW}$ ). R-squared values for the three models are $0.85,0.87$, and 0.89 , respectively.

\subsubsection{Unfired Hot Water Storage Tanks}

Cost information for unfired hot water storage tanks was collected from eight manufacturers for a total of 143 units. A cursory examination of the data suggests that equipment costs are a function of several factors, including the tank size; tank construction (standard or ASME); tank lining; and, for large-volume tanks, the tank orientation (vertical or horizontal). Storage tanks also come with different warranty lengths, insulation types, and pressure ratings. Modeling cost as a function of these parameters revealed four significant parameters: tank size, lining, orientation, and construction. Examination of cost plots as a function of each of these variables also revealed some nonstraight-line relationships in the data. A variety of models involving logs of the dependent and independent variables were tested to account for these relationships. The resulting model ( $\mathrm{R}$-squared $=0.93$ ), based on 123 units, is given below.

$$
\operatorname{Ln}(\mathrm{CCOST})=\begin{array}{cccc}
0.823 * \operatorname{Ln}(\mathrm{VOL}) \\
(0.0001) & 0.955 * \mathrm{TANK} & 0.235 * \text { ORIENT } & +.201 * \mathrm{LIN}+2.519 \\
(0.0001) & (0.0001) & (0.0002) & (0.0001)
\end{array}
$$

where VOL is the volume in gallons, and TANK, ORIENT, and LIN are indicator variables (TANK = 1 for ASME, 0 for standard; ORIENT $=1$ for horizontal, 0 for vertical; and LIN $=1$ for glass, 0 for other).

In the ASHRAE analysis, cost information was gathered for four tank sizes: 120, 200, 500, and 1,000 gal. ASHRAE-developed costs are compared against the range of modeled costs, based on equipment characteristics (with the three dummy variables all set to either 0 or 1 ). This comparison is presented in Table 6.5 . 
Table 6.5. Comparison of ASHRAE and Modeled Baseline Cost Estimates for Unfired Hot Water Storage Tanks

\begin{tabular}{||c|c|c||}
\hline Tank Volume & ASHRAE & \multicolumn{1}{|c|}{ Model } \\
\hline 120 gal & $\$ 1,922$ & $\$ 799-3,209$ \\
\hline $200 \mathrm{gal}$ & $\$ 3,198$ & $\$ 1,216-4,887$ \\
\hline $500 \mathrm{gal}$ & $\$ 8,033$ & $\$ 2,586-10,390$ \\
\hline $1,000 \mathrm{gal}$ & $\$ 13,155$ & $\$ 4,575-18,385$ \\
\hline
\end{tabular}

For tanks in the 120- and 200-gal size ranges, an option for horizontal orientation typically does not exist. Glass-lined tanks are also by far the most commonly offered models. Table 6.6 compares ASHRAE costs with modeled costs for vertical glass-lined storage tanks of both standard and ASME construction.

The ASHRAE-developed estimates fall between modeled cost estimates for glass-lined vertical standard and ASME models. A detailed understanding of shipment quantities, by type, for hot water storage tanks is necessary to accurately assess the baseline costs for this equipment.

\subsection{Packaged Boilers}

This equipment category includes a wide variety of boiler types, including copper finned-tube, castiron, and steel boilers. These boiler types have either atmospheric or forced draft combustion and output of either hot water or steam. Though ASHRAE collected cost data for both steel and iron boilers,

Table 6.6. Comparison of ASHRAE and Modeled Baseline Cost Estimates for Standard and ASME Construction Hot Water Storage Tanks

\begin{tabular}{||c|c|c|c|c||}
\hline $\begin{array}{c}\text { Tank } \\
\text { Volume }\end{array}$ & ASHRAE & $\begin{array}{c}\text { Model } \\
\text { Standard }\end{array}$ & $\begin{array}{c}\text { Model } \\
\text { ASME - Vertical }\end{array}$ & $\begin{array}{c}\text { Model } \\
\text { ASME - Horizontal }\end{array}$ \\
\hline $120 \mathrm{gal}$ & $\$ 1,922$ & $\$ 977$ & $\$ 2,538$ & N/A \\
\hline $200 \mathrm{gal}$ & $\$ 3,198$ & $\$ 1,487$ & $\$ 3,865$ & N/A \\
\hline $500 \mathrm{gal}$ & $\$ 8,033$ & $\$ 3,162$ & $\$ 8,218$ & $\$ 10,390$ \\
\hline $1,000 \mathrm{gal}$ & $\$ 13,155$ & $\$ 5,595$ & $\$ 14,541$ & $\$ 18,385$ \\
\hline
\end{tabular}


the baseline cost estimate was derived from costs for iron boilers only and was the average of estimated costs for atmospheric-type and power-burner-type boilers. ASHRAE considered only gas-fired boilers in the analysis.

Because energy efficiency regulations are insensitive to boiler type, boiler costs in this study were modeled pooled into two categories based on fuel type. Explanatory variables for the boiler types are then used to characterize cost differences between boiler types. The database contains nearly 700 boiler records, of which about 570 are gas-fired and 115 are oil-fired.

Gas-fired boilers are modeled as a function of input and efficiency, with dummy variables included to account for the cost increment for the following types of models:

- steam boilers $($ STEAM $=1$; otherwise $=0$ )

- units with vent dampers $($ VENT $=1$; otherwise $=0$ )

- units with electronic ignition (IGN $=1$; otherwise $=0$ )

- cast-iron boilers $($ IRON $=1$; otherwise $=0$ )

- steel boilers (STEEL $=1$; otherwise $=0$ )

- power-burner-type units $(\mathrm{BURN}=1$; otherwise $=0)$

- line of units offered by one manufacturer for which the model otherwise consistently underestimates costs (OUT $=1$; otherwise $=0$ ).

A total of 577 units were used to develop the model (R-squared $=0.94)$ given below.

$$
\begin{aligned}
& \text { CCOST }=3.23 * \text { INPUT }+2.64 * \mathrm{EFF}^{2}+931 * \text { IRON }+2,927 * \text { STEEL }+1,009 * \text { BURN }+ \\
& \begin{array}{llll}
(0.0001) & (0.0001) \quad(0.0001) \quad(0.0001) & (0.0001)
\end{array} \\
& 563 * \text { IGN }+1,116 * \text { STEAM }+6,518 * \text { OUT }-17,249 \\
& \begin{array}{lll}
(0.0153) \quad(0.0001) \quad(0.0001) & (0.0001)
\end{array}
\end{aligned}
$$

where INPUT is in $\mathrm{kBtu} / \mathrm{hr}$ and efficiency $(\mathrm{EFF})$ is a whole number $(80 \%=80)$. Evaluation of the high-cost outliers revealed that they represent a line of high-input units, but the evaluation does not reveal a simple characteristic that explains their high cost.

The model shown above is used to estimate costs for baseline efficiency equipment. Model-developed costs and ASHRAE cost estimates for cast-iron hot water boilers are presented in Table 6.7. The 
Table 6.7. Comparison of ASHRAE and Modeled Baseline Cost Estimates for Cast-Iron Hot Water Boilers

\begin{tabular}{|c|c|c|c||}
\hline Size & ASHRAE & $\begin{array}{c}\text { Model } \\
(\text { Atm) }\end{array}$ & $\begin{array}{c}\text { Model } \\
\text { (Power) }\end{array}$ \\
\hline $400 \mathrm{kBtu} / \mathrm{hr}$ & $\$ 5,015$ & $\$ 2,336$ & $\$ 3,599$ \\
\hline $800 \mathrm{kBtu} / \mathrm{hr}$ & $\$ 6,621$ & $\$ 4,655$ & $\$ 5,917$ \\
\hline $1,500 \mathrm{kBtu} / \mathrm{hr}$ & $\$ 9,258$ & $\$ 7,481$ & $\$ 8,743$ \\
\hline $3,000 \mathrm{kBtu} / \mathrm{hr}$ & $\$ 14,969$ & $\$ 13,538$ & $\$ 14,799$ \\
\hline
\end{tabular}

ignition is assumed to be the pilot for the smallest size category and electronic for the remaining categories. The dummy variables STEEL, STEAM, and OUT are set to zero. The baseline efficiency of the equipment is $80 \%$.

Modeled cost estimates for power-burner equipped boilers are similar to ASHRAE cost estimates, which are an average of atmospheric and power boilers, for the $800,1,500$ and 3,000 kBtu/hr size ranges. Modeled cost estimates for the $400 \mathrm{kBtu} / \mathrm{hr}$ size are significantly lower than ASHRAE cost estimates, which is primarily due to one extremely high power boiler cost estimate (Table 4.4). Model estimates are similar to the other four estimates used in this average. The cost difference between power and atmospheric boilers also narrows at larger-input ranges. This trend is apparent in the ASHRAE data as well.

The average combustion efficiency for cast-iron units in the database is $81 \%$. ASHRAE cost estimates are developed from units with either $80 \%$ or $81 \%$ efficiency. The baseline costs are then assumed to represent units with a thermal efficiency of $75 \%$. This reflects the fact that combustion efficiency is considered to be a poor measure of actual performance because it neglects jacket losses. ASHRAE is currently planning to move to a thermal efficiency standard, so the analysis is based on estimated cost increments as a function of thermal efficiency.

ASHRAE has not, at this point, evaluated oil-fired boilers. A preliminary analysis of the data for oil-fired boilers also suggests that there is insufficient information to adequately characterize the equipment. For this reason, baseline cost estimates for oil-fired equipment are not included here.

\subsection{Warm Air Furnaces}

Space heating in commercial establishments is provided by several distinct types of equipment. These include duct heaters, unit heaters, outdoor furnaces, indoor furnaces, and vertical air turnover (VATO) furnaces. EPAct specifically exempts both unit heaters and duct heaters from energy efficiency regulations. VATO furnaces are also excluded from EPAct standards, which cover only furnaces that supply heated air through ducts. The VATO operates by picking up cool air at floor level and discharging it at the top of the furnace. These units are primarily used in warehouses and other 
large storage areas. Of the remaining two furnace types, commercial indoor warm air furnaces represent a relatively small equipment class. In applications requiring indoor furnaces, one or more units may be used with capacities falling in the residential equipment range (below $225,000 \mathrm{Btu} / \mathrm{hr}$ ). Rooftop combination heating and air-conditioning units make up the remainder of the market, accounting for about 14\% of commercial and industrial energy use for space heating (Hewett and Lobenstein 1992, p. 41).

Cost information was provided only by manufacturers of indoor warm air furnaces. Baseline efficiencies for this equipment are $80 \%$ for gas-fired units and $81 \%$ for oil-fired units. The best fit model, based on all 57 data points, gives cost as a function of fuel type and input. This model (Rsquare $=0.82$ ) is given below.

$$
\begin{array}{cc}
\text { CCOST }= & 7.65 * \text { INPUT } \\
(0.0001) & 1,182 * \text { FUEL }
\end{array}+937
$$

where INPUT is in $\mathrm{kBtu} / \mathrm{hr}$ and FUEL is a dummy variable for the fuel type (FUEL $=1$ for oil; 0 for gas). There is only a small range of efficiencies for the units in the database, and no significant correlation was found between cost and efficiency. 


\subsection{Estimate of High-Efficiency Incremental Cost}

The statistical models described in Chapter 6.0 are used to estimate the incremental costs for highefficiency equipment. When model-developed incremental cost estimates are compared to ASHRAEdeveloped cost estimates, an understanding of the data from which the models were developed is critical. The models should not be used to estimate incremental costs for equipment that has characteristics that are outside the range of the data set from which they were developed.

\subsection{Water Heaters}

As with baseline costs, incremental costs for water-heating equipment were developed for four categories: fuel-fired storage water heaters, fuel-fired tankless water heaters, electric storage water heaters, and unfired hot water storage tanks.

\subsubsection{Fuel-Fired Storage Water Heaters}

The incremental cost associated with low-input high-efficiency storage water heaters can be estimated from the model described in Section 6.1.1. This model was developed from data for equipment up to $84 \%$ thermal efficiency and, therefore, cannot be extended to ranges with higher efficiency. Two $100,000 \mathrm{Btu} / \mathrm{hr}$ high-efficiency condensing models are offered, however, and by using manufacturer estimates of the added cost for these models, a cost increment can be estimated to reach the condensing regime (approximately $86 \%$ for gas fired equipment). The results are presented in Table 7.1 and are valid only for gas-fired equipment.

In the ASHRAE analysis, GAMA manufacturers estimated a $3 \%$ cost increase to achieve current standard levels. Based on the thermal efficiency, only 14 of 254 gas-fired units in the database do not meet the current standard. The ASHRAE incremental cost estimate to the $86 \%$ efficiency level also includes a reduction in standby losses. While this reduction can be expected to result in additional costs, it should be noted that the high-efficiency models that are the basis for this estimate achieve standby loss ratings of $1 \%$, well below the assumed standard level. Manufacturers have also indicated

Table 7.1. Comparison of ASHRAE and Modeled Incremental Cost Estimates for High-Efficiency Fuel-Fired Storage Water Heaters

\begin{tabular}{|c|c|c|}
\hline Efficiency & ASHRAE & Model \\
\hline $78 \%$ & $3 \%$ & $0 \%$ \\
\hline $80 \%$ & $10 \%$ & $3 \%$ \\
\hline $86 \%$ & $60 \%$ & $(50 \%)$ \\
\hline
\end{tabular}


that, though high-efficiency units are technologically achievable, other issues such as premature equipment failure have hindered the production of high-efficiency equipment, a fact that is mirrored in the limited number of such units on the market. An accurate assessment of the incremental costs for high-efficiency equipment must account for any decline in other performance aspects, something that is not done in analyses that assume the same level of nonefficiency-related performance across all efficiency levels.

The data for units with input greater than $155,000 \mathrm{Btu} / \mathrm{hr}$ did not reveal a statistically significant correlation between cost and efficiency, possibly because little variation in efficiency exists for this equipment. The results for units with input less than $155,000 \mathrm{Btu} / \mathrm{hr}$ were extrapolated to this size range. This is consistent with GAMA-supplied cost increment estimates, which are very similar for the two categories of equipment (Table 4.2).

\subsubsection{Tankless Water Heaters}

In the GAMA survey of commercial water heater manufacturers, incremental cost estimates for low-volume instantaneous (tankless) water heaters were provided for three levels of efficiency: $80 \%$ (baseline), $83 \%$, and $86 \%$. These estimates, along with estimates based on the model presented in Section 6.1.2, are given below in Table 7.2.

The GAMA-developed estimates are almost identical to modeled incremental costs for the $400 \mathrm{kBtu} / \mathrm{hr}$ size category and somewhat higher than for the $1,000 \mathrm{kBtu} / \mathrm{hr}$ size category. The model also suggests that as rated input increases, the incremental cost for high-efficiency equipment decreases. This trend is confirmed by looking at equipment of various efficiency levels produced by a single manufacturer. This has important implications for life-cycle cost estimates because larger equipment will also have greater fuel input, thus weighting the impact of fuel savings on life- cycle cost. Because the ASHRAE analysis is based on a $400 \mathrm{kBtu} / \mathrm{hr}$ model, which is relatively small, the life-cycle cost estimates for larger high-efficiency equipment may be inflated.

Table 7.2. Comparison of ASHRAE and Modeled Incremental Cost Estimates for Tankless Water Heaters

\begin{tabular}{|c|c|c|c|}
\hline Efficiency & GAMA & Model (400 kBtu) & Model (1000 kBtu) \\
\hline $80 \%$ (Baseline) & $0 \%$ & $0 \%$ & $0 \%$ \\
\hline $83 \%$ & $24 \%$ & $27 \%$ & $19 \%$ \\
\hline $86 \%$ & $85 \%$ & $85 \%$ & $57 \%$ \\
\hline
\end{tabular}




\subsubsection{Electric Storage Water Heaters}

No ASHRAE analysis has been conducted on the incremental costs for high-efficiency electric storage water heaters. Current standards apply only to standby losses, because thermal efficiencies are near $100 \%$ for this equipment. The existing standby loss performance standard for commercial electric water heaters is given as a function of water storage volume, in gallons, and must be less than $0.30+$ $27 / \mathrm{Vol}$. The standard is related to storage volume to account for the relationship between storage volume and the surface area for tanks of different sizes. As volume increases, the surface-area-to-volume ratio for tanks with equal relative proportions decreases. For tanks with equal effective insulation, standby losses decrease when the volume increases. This finding is reflected in the standard.

Commercial electric storage water heaters in the 50- to 120-gal size range are currently manufactured almost exclusively with about 3 in. of foam insulation. This results in standby loss performance that is near the current ASHRAE standard, as can be seen by examining standby loss data for these models listed in the database. These models are marketed as having R-values of 24 or 25 . However, reaching such high levels of $\mathrm{R}$-value has become more difficult because of an Environmental Protection Agency ban on the use of choloroflourocarbon (CFC)-based foaming agents, such as CFC R-11, with an R-value of about 8 per inch. A replacement non-CFC foaming agent, HCFC 141b, is estimated to have an R-value of about 7.5/in., effectively requiring more than 3-1/8 in. of foam to reach R-24. Manufacturers have also improved on the effective insulation value by increasing the amount of insulation on top of the tank, decreasing the surface area of nonfoam insulation around the controls and heating elements, and improving the insulation (typically fiberglass) below the tanks.

Incremental material costs for increasing the insulation level to 4 in. can be calculated from tank dimensions and estimated costs for foam insulation $\left(\$ 1.50 / \mathrm{lb}\right.$ at $\left.2.2 \mathrm{lb} / \mathrm{ft}^{3}\right)$ and 20 -gauge steel-jacketing material ( $\$ 0.32 \mathrm{lb}$ at $\left.1.5 \mathrm{lb} / \mathrm{ft}^{2}\right)$. Cost increases range from $\$ 11$ for a 50 -gal model to $\$ 18$ for a 120 -gal model. Based on a manufacturer markup of about $53.8 \%$ (gross margin of $65 \%$ ), $10 \%$ dealer markup, and $25 \%$ contractor markup, this would add $\$ 23$ to $\$ 38$ in additional material costs at the consumer level. This equates to about a $2 \%$ increase in costs for non-ASME surface thermostat models.

Other considerations, such as the overall size of the water heater, limit the potential for increasing insulation levels. Incremental energy savings also become extremely small as insulation levels increase, partly because energy "leaks" around the piping and fittings begin to outweigh losses through the insulation. Greater potential for energy savings exists through substitution of alternative waterheating mechanisms. Solar water heaters can potentially save large quantities of energy, but because their performance depends on climate, they are perhaps not suitable for inclusion in a national standard. Fuel-fired water heaters also reduce overall energy consumption when electricity generation losses are accounted for. Heat pump water heaters offer the potential for large energy savings, but their performance is highly dependent on ambient conditions. While the baseline cost model in Section 6.1.3 cannot be extrapolated to such low-input ranges, light commercial electric water heaters with 120 -gal storage capacity and $4.5 \mathrm{~kW}$ input (recovery of $20 \mathrm{gal} / \mathrm{hr}$ at $90^{\circ} \mathrm{F}$ rise) typically cost about $\$ 1,000$. A commercial heat pump water heater that provides the same level of service costs approximately $\$ 3,600$, an increase of $260 \%$ compared to an electric water heater. 


\subsubsection{Unfired Hot Water Storage Tanks}

Little information is available on the standby loss performance of unfired hot water storage tanks, and little variability exists in the level of insulation used by different manufacturers on similar models. Reported R-values typically range from 13 to 16.7 ; however, these may only be rough approximations based on the estimated performance of the particular type of insulation used. The incremental costs associated with improving the standby loss performance of storage tanks can be estimated by examining the types; quantities, and qualities of insulation used with these tanks.

Several water heater manufacturers and insulation manufacturers were contacted on the thermal performance of insulation. Estimates of the $\mathrm{k}$-value for fiberglass water heater insulation ranged from 0.22 to 0.3 , with an average of 0.27 (the units on $\mathrm{k}$ are Btu-in. $/ \mathrm{hr} / \mathrm{ft}^{2} / \mathrm{F}$ ). This translates to an $\mathrm{R}$-value of about 3.7/in. or R-14.8 for 4 in. of insulation. The theoretical heat loss for a planar surface insulated to this level, combined with a temperature difference of $80^{\circ} \mathrm{F}$, is $5.4 \mathrm{Btu} / \mathrm{hr} * \mathrm{ft}^{2}$. By comparison, foam insulation has $k$-values in the range of 0.11 to 0.14 . The first value is typical of foams such as CFC R-11, and the latter value is typical of non-CFC foams, such as HCFC 141b. Using an estimate of the insulating capability of non-CFC foam gives an R-value of 7.5/in. Thus, 2 in. of foam insulation, which is common on storage tanks in the 120- to 200-gal size, yields an R-value of 15 and a theoretical heat loss rate of $5.3 \mathrm{Btu} / \mathrm{hr}^{*} \mathrm{ft}^{2}$.

Both of these values are below the current standard of $6.5 \mathrm{Btu} / \mathrm{hr}^{*} \mathrm{ft}^{2}$, though actual losses for storage tanks insulated to these levels would be higher. Heat loss from a hot water storage tank will differ from this based on the shape of the tank, and the number and extent of "leaks" around the insulation caused by inlet and outlet pipes, and other extrusions such as pressure relief valves. Free convection of heat can also occur if heat traps are not used to control migration of hot water into the cool pipes. Despite these considerations, it is possible to estimate the incremental material cost to increase the quantity of insulation, based on the estimated cost of the additional materials used. Cost increments, as a percentage of baseline costs, are presented in Table 7.3.

In the GAMA commercial water heater survey, manufacturers were asked to estimate the incremental cost to improve the thermal performance of storage tanks from a maximum of $13.6 \mathrm{Btu} / \mathrm{hr} * \mathrm{ft}^{2}$ to 6.5 Btu/hr*ft. This represents a $52 \%$ increase in the effective insulation value. Estimates are that achieving $13.6 \mathrm{Btu} / \mathrm{hr} / \mathrm{ft}^{2}$ would cost an additional $3 \%$, and achieving $6.5 \mathrm{Btu} / \mathrm{hr} / \mathrm{ft}^{2}$ would cost an additional $10 \%$ over an assumed baseline. These estimates include non-material-related cost increases and can be expected to be higher than estimates based only on incremental material costs.

Table 7.3. Incremental Material Cost Estimates for Highly Insulated Hot Water Storage Tanks

\begin{tabular}{||l|c|c|c|c|}
\hline \multicolumn{1}{|c|}{ Tank Volume } & $120 \mathrm{Gal}$ & $\mathbf{2 0 0}$ Gal & $\mathbf{5 0 0}$ Gal & $1,000 \mathrm{Gal}$ \\
\hline 2-in. Fiberglass & $0 \%$ & $0 \%$ & $0 \%$ & $0 \%$ \\
\hline 2-in. Foam & $2 \%$ & $2 \%$ & $1 \%$ & $1 \%$ \\
\hline 3-in. Foam & $6 \%$ & $5 \%$ & $4 \%$ & $3 \%$ \\
\hline
\end{tabular}




\subsection{Packaged Boilers}

The incremental costs for high-efficiency packaged boilers can be estimated from the model developed in Section 6.2. This model is based on combustion efficiencies and is therefore not directly comparable to ASHRAE-developed incremental cost estimates, which are based on thermal efficiency. The results for an $800 \mathrm{kBtu} / \mathrm{hr}$ atmospheric cast-iron boiler are presented in Table 7.4.

For this size class, incremental cost estimates are similar for small incremental-efficiency improvements, but the model results are much smaller for larger incremental-efficiency improvements. However, the model should not be used to extrapolate beyond the range of the data set. For cast-iron boilers, the range of efficiencies is only $80 \%$ to $83.3 \%$. Above this level, the model is only valid for copper- or copper/nickel-type boilers. Because efficiency standards are not equipment-type dependent, the model can be used to evaluate cost increments that are independent of equipment type. The model can similarly be used to evaluate incremental costs for other boiler size classes.

\subsection{Warm Air Furnaces}

The ASHRAE furnace analysis is based on outdoor furnaces, a category of equipment manufactured primarily by large HVAC equipment companies. Because these manufacturers have declined to provide information, it is not possible to evaluate the ASHRAE incremental cost estimates at this time. Furthermore, there is little variability in efficiency between indoor-type warm air furnaces, so no incremental cost estimates can be made for high-efficiency furnaces based on the available data.

Table 7.4. Comparison of ASHRAE and Modeled Incremental Cost Estimates for Packaged Atmospheric Hot Water Boilers $(800 \mathrm{kBtu} / \mathrm{hr})$

\begin{tabular}{||c|c|c|c|}
\hline $\begin{array}{c}\text { Thermal } \\
\text { Efficiency }\end{array}$ & ASHRAE & $\begin{array}{c}\text { Combustion } \\
\text { Efficiency }\end{array}$ & Model \\
\hline $75 \%$ & $0 \%$ & $80 \%$ & $0 \%$ \\
\hline $76 \%$ & $10 \%$ & $81 \%$ & $11 \%$ \\
\hline $77 \%$ & $15 \%$ & $82 \%$ & $23 \%$ \\
\hline $78 \%$ & $22 \%$ & $83 \%$ & $35 \%$ \\
\hline $79 \%$ & $44 \%$ & $84 \%$ & $47 \%$ \\
\hline $80 \%$ & $114 \%$ & $85 \%$ & $(58 \%)$ \\
\hline $82 \%$ & $121 \%$ & $87 \%$ & $(83 \%)$ \\
\hline $84 \%$ & $261 \%$ & $89 \%$ & $(108 \%)$ \\
\hline $88 \%$ & $450 \%$ & $91 \%$ & $(133 \%)$ \\
\hline
\end{tabular}




\subsection{Conclusions}

The purpose of this work is to support an evaluation of the economic impact of revised commercial equipment standards. A database of commercial equipment costs was created, and information from this database was used to develop models for baseline and high-efficiency equipment costs. In some cases, sufficient data were not available on high-efficiency equipment to accurately evaluate the incremental costs for this equipment. Where possible, other means were used to evaluate these costs. Also, information was not available for heat pumps, air conditioners, and outdoor warm air furnaces. Further data collection will be required to analyze costs for these types of equipment.

The problems encountered in the cost data collection effort highlight the difficulty in making accurate assessments of equipment costs. Not only is cost information considered sensitive and is thus difficult to collect, but the wide variability of cost estimates also makes an accurate evaluation of costs extremely difficult. There is no single correct cost that can be associated with a given piece of equipment. However, by collecting a large quantity of data, it is possible to average out extreme values, identifying factors that affect costs. Statistical tools can also be employed to quantify the quality of the data and to reveal relationships between equipment parameters and cost.

Some consideration of the primary measure used in this study, list price, is appropriate. List price figures, in themselves, do not specifically measure the actual cost of the equipment at the wholesale, contractor, or consumer level. Also, list prices may not accurately reflect the relationship of prices between products manufactured by the same company. However, within a given product line, it is assumed that list prices, to some extent, reflect the manufactured cost associated with the size and features of each piece of equipment and that these costs will, on the whole, be passed on to the consumer. Through statistical analysis of relative costs as a function of equipment parameters, models that relate cost to these parameters can be developed.

The results of this study show some of the strengths and weaknesses of this approach. For baseline cost estimates, the models provide a useful tool for evaluating the important equipment characteristics that affect cost. From this understanding of the relationship between equipment characteristics and cost, an informed baseline cost estimate can be made that precisely defines the attributes of the assumed baseline model. For incremental cost estimates, the models also provide a method for estimating the incremental costs for high- efficiency equipment. In some cases, however, no significant relationship was found between performance and cost. This was primarily due to the fact that for some equipment categories there was little range in efficiency for equipment currently being marketed. These categories include electric storage water heaters; unfired hot water storage tanks, and warm air furnaces for indoor installation.

When the modeled baseline cost estimates are compared to ASHRAE-developed cost estimates, two important conclusions can be drawn. First, ASHRAE baseline cost estimates do not contain sufficient information about the assumed characteristics of the equipment to accurately estimate costs. The model results highlight the wide range of possible costs based on equipment features that are typically offered 
with commercial equipment. Second, a comparison of ASHRAE and modeled cost estimates revealed that a small number of extremely high cost estimates used by ASHRAE heavily impacted the average cost estimates. Thus, ASHRAE baseline cost estimates were generally similar to or higher than modeled baseline cost estimates. High baseline cost estimates will tend to diminish the importance of energy savings on life-cycle costs for high-efficiency equipment, shifting the minimum life-cycle cost towards lower efficiency levels.

Two important conclusions can also be drawn when comparing the modeled incremental cost estimates to ASHRAE-developed incremental cost estimates. First, in some cases, ASHRAE estimates are not size specific. The modeled results suggest that equipment size does affect incremental costs. This is clear in the incremental cost estimates for tankless water heaters, which differ significantly between size ranges. For the size range used by ASHRAE, modeled and ASHRAE incremental cost estimates are almost identical. For larger-sized equipment, the model predicts a smaller cost increment, highlighting the importance of equipment size on the results. Second, the ASHRAE incremental cost estimates are often equipment-type specific, which affects the magnitude of incremental costs. In the case of packaged boilers, model results were developed as a function of equipment type. In this way, incremental costs can be independently estimated for these equipment types. This may be of value because EPAct standards are not equipment-type dependent.

Several categories of equipment were not included in the analysis because of lack of data. These include all categories of heat pumps and air conditioners, warm air furnaces for outdoor installation, and several types of oil-fired equipment. Additional data collection will be required to evaluate baseline and incremental costs for this equipment. The results of this study suggest, however, that list price information can be used to estimate these costs, with other information used to supplement list price data where necessary. 


\subsection{References}

American Gas Association. 1993. American National Standard: Gas Water Heater Volume III: Storage with Input Ratings Above 75,000 Btu per hour, Circulating and Instantaneous Water Heaters. ANSI Z21.10.3, AGA. Cleveland, Ohio.

American Society of Heating, Refrigerating, and Air-Conditioning Engineers, Inc. 1993. Energy Code for Commercial and High-Rise Residential Buildings. Codification of ASHRAE/IES 90.1-1989, Energy Efficient Design of New Buildings Except Low-Rise Residential Buildings, Atlanta, Georgia.

Appliance Manufacturer. 1994. "Environmental Comfort Shipments.” Appliance Manufacturer 10-94:15.

Energy Policy Act of 1992. Public Law 102-486 as amended, 42 USC 13201.

Hewett, M. J., and M. S. Lobenstein. 1992. Commercial Gas Space Heating Equipment: Opportunities to Increase Energy Efficiency. Report to Minnegasco, Inc. by the Center for Energy and the Urban Environment, CEUE/TR91-3-CM, Minneapolis, Minnesota.

Hydronics Institute. 1994. $I=B=R$ Ratings for Boilers, Baseboard Radiation and Finned Tube (Commercial) Radiation. The Hydronics Institute, January 1, 1994, Berkeley Heights, New Jersey. 


\section{Appendix A}

\section{Equipment Database Tables}

The commercial equipment database is presented in the following six tables. Field definitions for each of these tables are given in Chapter 5.0. Some data have been deleted from these tables to protect the proprietary interests of the manufactures. This is represented by an asterisk $\left(^{*}\right)$ in the tables. These missing values are left blank, and represent information that was unavailable. Every effort has been made to ensure the accuracy of this data; however, in the course of data collection and data entry, some errors are inevitable. 
Table A.1. Fuel-Fired Storage Water Heaters

\begin{tabular}{|c|c|c|c|c|c|c|c|c|c|c|c|}
\hline REC & FUEL & VOL & INPUT & EFF & STBY & TANK & BURN & WARR & CTYPE & LCOST & CCOST \\
\hline 1,000 & $\mathbf{G}$ & 20 & 150 & 80 & & $A$ & A & 5 & $\mathbf{R}$ & 2,103 & 2,103 \\
\hline 1,001 & $\mathbf{G}$ & 20 & 120 & 80 & & $\mathrm{~A}$ & $\bar{A}$ & 5 & $\mathbf{R}$ & 2,069 & 2,069 \\
\hline 1,002 & G & 30 & 180 & 80 & & $A$ & $\bar{A}$ & 5 & $\mathrm{R}$ & 2,244 & 2,244 \\
\hline 1,003 & $\mathbf{G}$ & 30 & 240 & 80 & & A & A & 5 & $\mathrm{R}$ & 2,311 & 2,311 \\
\hline 1,004 & $\mathbf{G}$ & 30 & 150 & 81 & 4.2 & $S$ & $\mathrm{~A}$ & 3 & $\mathrm{D}$ & 1,747 & 1,939 \\
\hline 1,005 & $\mathbf{G}$ & 30 & 150 & 81 & 4.2 & $S$ & A & 5 & $\mathrm{D}$ & 1,887 & 2,095 \\
\hline 1,006 & G & 30 & 200 & 79 & 4.7 & $S$ & $A$ & 3 & D & 1,775 & 1,970 \\
\hline 1,007 & $\mathbf{G}$ & 30 & 200 & 79 & 4.7 & $S$ & A & 5 & $\mathrm{D}$ & 1,917 & 2,128 \\
\hline 1,008 & G & 30 & 230 & 77 & 4.7 & A & $\bar{A}$ & 3 & D & 2,285 & 2,536 \\
\hline 1,009 & $\mathbf{G}$ & 30 & 230 & 77 & 4.7 & $A$ & $A$ & 5 & $D$ & 2,468 & 2,739 \\
\hline 1,010 & G & 30 & 230 & 77 & 4.7 & $S$ & $\bar{A}$ & 3 & D & 1,828 & 2,029 \\
\hline 1,011 & G & 30 & 230 & 77 & 4.7 & S & $A$ & 5 & $D$ & 1,974 & 2,191 \\
\hline 1,012 & $\mathbf{G}$ & 30 & 100 & 94 & 1.0 & $S$ & $P$ & 3 & $\mathrm{D}$ & 1,424 & 1,581 \\
\hline 1,013 & $\mathbf{G}$ & 40 & 150 & 80 & & $S$ & $A$ & 3 & $\mathbf{R}$ & 2,691 & 1,776 \\
\hline 1,014 & $\mathbf{G}$ & 40 & 300 & 80 & & A & A & 5 & $\mathbf{R}$ & 2,444 & 2,444 \\
\hline 1,015 & $\mathbf{G}$ & 40 & 150 & 78 & 3.2 & $S$ & A & 3 & $D$ & 1,747 & 1,939 \\
\hline 1,016 & $\mathbf{G}$ & 40 & 150 & 78 & 3.2 & $S$ & A & 3 & $D$ & 1,747 & 1,939 \\
\hline 1,017 & $\mathbf{G}$ & 40 & 160 & 79 & 3.5 & $S$ & A & 3 & $D$ & 1,711 & 1,899 \\
\hline 1,018 & $\mathbf{G}$ & 50 & 100 & 80 & 3.0 & $S$ & $A$ & 3 & D & 1,282 & 1,423 \\
\hline 1,019 & 0 & 50 & 190 & 78 & 3.1 & S & $P$ & 1 & $\bar{D}$ & 850 & 935 \\
\hline 1,020 & $\mathbf{G}$ & 50 & 100 & 94 & 1.0 & $\mathrm{~S}$ & $P$ & 3 & $\bar{D}$ & 1,569 & 1,742 \\
\hline 1,021 & $\mathbf{G}$ & 70 & 360 & 84 & 2.8 & $A$ & $A$ & 3 & D & 2,968 & 3,294 \\
\hline 1,022 & $\mathbf{G}$ & 70 & 360 & 84 & 2.8 & $S$ & A & 3 & D & 2,509 & 2,785 \\
\hline 1,023 & $\mathbf{G}$ & 70 & 370 & 81 & 2.7 & A & $\bar{A}$ & 3 & D & 2,963 & 3,289 \\
\hline 1,024 & $\mathbf{G}$ & 70 & 370 & 81 & 2.7 & A & $A$ & 3 & D & 2,963 & 3,289 \\
\hline 1,025 & $\mathbf{G}$ & 70 & 370 & 80 & 0.0 & A & $A$ & 3 & $\mathbf{R}$ & 5,072 & 3,348 \\
\hline 1,026 & $\mathbf{G}$ & 70 & 370 & 81 & 2.7 & $S$ & $A$ & 3 & D & 2,506 & 2,782 \\
\hline 1,027 & $\mathbf{G}$ & 70 & 370 & 81 & 2.7 & $S$ & $A$ & 3 & D & 2,506 & 2,782 \\
\hline 1,028 & $\mathbf{G}$ & 70 & 370 & 80 & 0.0 & S & $A$ & 3 & $\mathbf{R}$ & 4,364 & 2,880 \\
\hline 1,029 & $G$ & 70 & 400 & 80 & 2.9 & $\bar{A}$ & $\bar{A}$ & 3 & D & 3,245 & 3,602 \\
\hline 1,030 & G & 70 & 400 & 80 & 2.9 & A & A & 3 & D & 3,235 & 3,591 \\
\hline 1,031 & $\mathbf{G}$ & 70 & 400 & 80 & 2.9 & $S$ & A & 3 & $D$ & 3,033 & 3,367 \\
\hline 1,032 & $\mathbf{G}$ & 70 & 400 & 80 & 2.9 & $S$ & A & 3 & $D$ & 2,787 & 3,094 \\
\hline 1,033 & $G$ & 70 & 630 & 82 & 2.1 & $A$ & A & 3 & D & 4,110 & 4,562 \\
\hline 1,034 & $\mathbf{G}$ & 70 & 630 & 82 & 2.1 & A & $\mathrm{A}$ & 3 & D & 4,680 & 5,195 \\
\hline 1,035 & G & 70 & 630 & 80 & 0.0 & A & A & 3 & $R$ & 7,191 & 4,746 \\
\hline 1,036 & $G$ & 70 & 630 & 82 & 2.1 & $\mathrm{~S}$ & A & 3 & D & 3,570 & 3,963 \\
\hline 1,037 & $\mathbf{G}$ & 70 & 630 & 82 & 2.1 & $S$ & A & 3 & D & 4,269 & 4,739 \\
\hline 1,038 & $G$ & 70 & 630 & 80 & 0.0 & $S$ & $A$ & 3 & $\mathbf{R}$ & 6,834 & 4,510 \\
\hline 1,039 & G & 70 & 120 & 79 & 2.9 & $S$ & A & 3 & $D$ & 1,420 & 1,576 \\
\hline 1,040 & $\mathbf{G}$ & 70 & 370 & 80 & 3.2 & A & $\mathrm{A}$ & 3 & D & 2,966 & 3,292 \\
\hline 1,041 & $\mathbf{G}$ & 70 & 370 & 80 & 3.2 & $S$ & $\mathrm{~A}$ & 3 & D & 2,508 & 2,784 \\
\hline 1,042 & $\mathbf{G}$ & 70 & 500 & & & A & $\mathrm{A}$ & 3 & $D$ & 3,956 & 4,391 \\
\hline 1,043 & $G$ & 70 & 500 & & & $S$ & $A$ & 3 & $D$ & 3,487 & 3,871 \\
\hline 1,044 & $\mathbf{G}$ & 70 & 540 & & & $A$ & $P$ & 3 & $D$ & 4,168 & 4,626 \\
\hline
\end{tabular}


Table A.1. Fuel-Fired Storage Water Heaters (contd)

\begin{tabular}{|c|c|c|c|c|c|c|c|c|c|c|c|}
\hline REC & FUEL & VOL & INPUT & EFF & STBY & TANK & BURN & WARR & CTYPE & LCOST & CcosT \\
\hline 1,045 & 0 & 70 & 700 & 80 & 3.2 & A & $\mathbf{P}$ & 3 & D & 5,118 & 5,681 \\
\hline 1,046 & $\mathbf{G}$ & 70 & 700 & 80 & 3.2 & $A$ & $\mathbf{P}$ & 3 & $\mathrm{D}$ & 4,704 & 5,221 \\
\hline 1,047 & 0 & 70 & 700 & 80 & 3.2 & $\mathrm{~S}$ & $P$ & 3 & D & 4,024 & 4,467 \\
\hline 1,048 & 0 & 70 & 250 & 78 & 3.0 & $S$ & $\mathbf{P}$ & 1 & $\mathrm{D}$ & 1,000 & 1,100 \\
\hline 1,049 & $\mathbf{G}$ & 70 & 360 & 82 & 2.5 & $\bar{A}$ & A & 3 & $D$ & 2,963 & 3,289 \\
\hline 1,050 & $\mathbf{G}$ & 70 & 360 & 82 & 2.5 & A & $\mathrm{A}$ & 5 & $\mathrm{D}$ & 3,200 & 3,552 \\
\hline 1,051 & $\mathbf{G}$ & 70 & 360 & 82 & 2.5 & S & $\mathrm{A}$ & 3 & $\bar{D}$ & 2,506 & 2,782 \\
\hline 1,052 & $\mathbf{G}$ & 70 & 360 & 82 & 2.5 & $S$ & A & 5 & $\mathrm{D}$ & 2,706 & 3,004 \\
\hline 1,053 & $\mathbf{G}$ & 70 & 140 & 82 & 2.0 & $S$ & $A$ & 3 & $\mathrm{D}$ & 1,762 & 1,956 \\
\hline 1,054 & $\mathbf{G}$ & 70 & 410 & 80 & & $A$ & A & 5 & $\mathbf{R}$ & 4,167 & 4,167 \\
\hline 1,055 & $\mathbf{G}$ & 80 & 80 & 79 & 2.3 & $S$ & $A$ & 3 & $\bar{D}$ & 754 & 837 \\
\hline 1,056 & $\mathbf{G}$ & 80 & 80 & 83 & 2.8 & $S$ & A & 3 & D & 753 & 836 \\
\hline 1,057 & $G$ & 80 & 80 & 80 & 0.0 & $S$ & $\bar{A}$ & 3 & $\bar{R}$ & 1,313 & 867 \\
\hline 1,058 & G & 80 & 90 & & & $S$ & A & 3 & $\mathrm{D}$ & 1,003 & 1,113 \\
\hline 1,059 & $\mathbf{G}$ & 80 & 120 & 79 & 2.5 & $S$ & $\bar{A}$ & 3 & $\mathrm{D}$ & 1,460 & 1,621 \\
\hline 1,060 & $\mathbf{G}$ & 80 & 120 & 79 & 2.5 & S & $\bar{A}$ & 5 & $\mathrm{D}$ & 1,577 & 1,750 \\
\hline 1,061 & $\mathbf{G}$ & 80 & 120 & 79 & 2.2 & $\mathrm{~S}$ & A & 3 & D & 1,417 & 1,573 \\
\hline 1,062 & G & 80 & 130 & 83 & 1.9 & $S$ & $A$ & 3 & D & 1,460 & 1,621 \\
\hline 1,063 & G & 80 & 130 & 80 & 0.0 & S & $A$ & 3 & $\mathbf{R}$ & 2,529 & 1,669 \\
\hline 1,064 & $\mathbf{G}$ & 80 & 130 & 83 & 1.9 & $S$ & $\bar{A}$ & 3 & D & 1,417 & 1,573 \\
\hline 1,065 & G & 80 & 140 & 78 & 2.6 & $\bar{s}$ & $\bar{A}$ & 3 & D & 1,787 & 1,984 \\
\hline 1,066 & $\mathbf{G}$ & 80 & 140 & 78 & 2.6 & $\mathrm{~S}$ & A & 5 & $\mathrm{D}$ & 1,930 & 2,142 \\
\hline 1,067 & $\mathbf{G}$ & 80 & 160 & 80 & 0.0 & $S$ & A & 3 & $\mathbf{R}$ & 2,797 & 1,846 \\
\hline 1,068 & $\mathbf{G}$ & 80 & 160 & 78 & 2.1 & $\mathrm{~S}$ & A & 3 & D & 1,787 & 1,984 \\
\hline 1,069 & G & 80 & 160 & 78 & 2.1 & $S$ & A & 3 & D & 1,787 & 1,984 \\
\hline 1,070 & G & 80 & 190 & & & $S$ & A & 3 & D & 1,873 & 2,079 \\
\hline 1,071 & $\mathbf{G}$ & 80 & 250 & 81 & 2.0 & $\bar{A}$ & $\bar{A}$ & 3 & $\bar{D}$ & 2,428 & 2,695 \\
\hline 1,072 & $\mathbf{G}$ & 80 & 250 & 81 & 2.0 & A & A & 5 & D & 2,622 & 2,910 \\
\hline 1,073 & $G$ & 80 & 250 & & & $\bar{A}$ & A & 3 & D & 2,585 & 2,869 \\
\hline 1,074 & G & 80 & 250 & 81 & 2.4 & S & A & 3 & D & 1,972 & 2,189 \\
\hline 1,075 & G & 80 & 250 & 81 & 2.4 & $S$ & $\bar{A}$ & 5 & $\bar{D}$ & 2,130 & 2,364 \\
\hline 1,076 & $\mathbf{G}$ & 80 & 250 & & & $S$ & $A$ & 3 & $\bar{D}$ & 2,049 & 2,274 \\
\hline 1,077 & $\mathbf{G}$ & 80 & 300 & 79 & 2.2 & A & A & 3 & D & 2,648 & 2,939 \\
\hline 1,078 & G & 80 & 300 & 79 & 2.2 & $\bar{A}$ & $\bar{A}$ & 5 & $\bar{D}$ & 2,860 & 3,175 \\
\hline 1,079 & $\mathbf{G}$ & 80 & 300 & 81 & 1.9 & $A$ & $A$ & 3 & $D$ & 2,648 & 2,939 \\
\hline 1,080 & G & 80 & 300 & 81 & 1.9 & A & $\bar{A}$ & 3 & $\bar{D}$ & 2,648 & 2,939 \\
\hline 1,081 & $\mathbf{G}$ & 80 & 300 & 80 & 0.0 & $A$ & A & 3 & $R$ & 4,791 & 3,162 \\
\hline 1,082 & G & 80 & 300 & 81 & 1.9 & S & A & 3 & D & 2,191 & 2,432 \\
\hline 1,083 & G & 80 & 300 & 79 & 2.2 & $S$ & A & 3 & D & 2,191 & 2,432 \\
\hline 1,084 & $\mathbf{G}$ & 80 & 300 & 79 & 2.2 & $S$ & A & 5 & D & 2,366 & 2,626 \\
\hline 1,085 & $\mathbf{G}$ & 80 & 300 & 81 & 1.9 & $S$ & A & 3 & D & 2,191 & 2,432 \\
\hline 1,086 & $\mathbf{G}$ & 80 & 300 & 80 & 0.0 & $S$ & A & 3 & $\mathbf{R}$ & 3,936 & 2,598 \\
\hline 1,087 & $\mathbf{G}$ & 80 & 310 & 80 & 2.8 & A & A & 3 & D & 2,650 & 2,942 \\
\hline 1,088 & $\mathbf{G}$ & 80 & 310 & 80 & 2.8 & $S$ & A & 3 & $\bar{D}$ & 2,193 & 2,434 \\
\hline 1,089 & G & 80 & 370 & & & $A$ & $P$ & 3 & D & 3,830 & 4,251 \\
\hline
\end{tabular}


Table A.1. Fuel-Fired Storage Water Heaters (contd)

\begin{tabular}{|c|c|c|c|c|c|c|c|c|c|c|c|}
\hline REC & FUEL & VOL & INPUT & EFF & STBY & TANK & BURN & WARR & CTYPE & $\overline{L C O S T}$ & CcosT \\
\hline 1,090 & $\mathbf{G}$ & 80 & 370 & & & $S$ & $P$ & 3 & $D$ & 2,956 & 3,281 \\
\hline 1,091 & 0 & 80 & 390 & 80 & 3.1 & $\mathrm{~A}$ & $\mathbf{P}$ & 3 & D & 3,703 & 4,110 \\
\hline 1,092 & 0 & 80 & 390 & 80 & 3.1 & $\mathrm{~s}$ & $P$ & 3 & D & 2,796 & 3,104 \\
\hline 1,093 & $\mathbf{G}$ & 80 & 400 & 77 & 2.9 & $\bar{A}$ & $\bar{A}$ & 3 & $\bar{D}$ & 3,245 & 3,602 \\
\hline 1,094 & $\mathbf{G}$ & 80 & 400 & 77 & 2.9 & $S$ & A & 3 & $\mathrm{D}$ & 3,033 & 3,367 \\
\hline 1,095 & 0 & 80 & 460 & 78 & 3.1 & $\bar{A}$ & $P$ & 3 & D & 4,273 & 4,743 \\
\hline 1,096 & 0 & 80 & 460 & 78 & 3.1 & $\mathrm{~S}$ & $P$ & 3 & D & 3,269 & 3,629 \\
\hline 1,097 & $\mathbf{G}$ & 80 & 500 & 80 & & A & A & 5 & $\mathbf{R}$ & 5,102 & 5,102 \\
\hline 1,098 & $\mathbf{G}$ & 80 & 180 & 80 & 2.0 & $\mathrm{~S}$ & $\bar{A}$ & 3 & D & 1,835 & 2,037 \\
\hline 1,099 & G & 80 & 200 & 82 & 2.6 & S & A & 3 & $\bar{D}$ & 1,899 & 2,108 \\
\hline 1,100 & $\mathbf{G}$ & 80 & 500 & 82 & 3.1 & $\bar{A}$ & $\bar{A}$ & 3 & $\bar{D}$ & 3,900 & 4,329 \\
\hline 1,101 & $\mathbf{G}$ & 80 & 500 & 82 & 3.1 & $\mathrm{~S}$ & A & 3 & D & 3,429 & 3,806 \\
\hline 1,102 & $\mathbf{G}$ & 80 & 600 & 79 & & A & $\bar{A}$ & 3 & D & 4,110 & 4,562 \\
\hline 1,103 & $\mathbf{G}$ & 80 & 600 & 79 & & $S$ & $\bar{A}$ & 3 & D & 3,570 & 3,963 \\
\hline 1,104 & $\mathbf{G}$ & 80 & 180 & 79 & 2.0 & $S$ & A & 3 & D & 1,835 & 2,037 \\
\hline 1,105 & $\mathbf{G}$ & 80 & 180 & 79 & 2.0 & S & A & 5 & $\bar{D}$ & 1,982 & 2,200 \\
\hline 1,106 & $\mathbf{G}$ & 80 & 180 & 81 & 2.3 & S & A & 3 & $\bar{D}$ & 1,835 & 2,037 \\
\hline 1,107 & $\mathbf{G}$ & 80 & 180 & 80 & & $S$ & $\bar{A}$ & 3 & $R$ & 3,187 & 2,103 \\
\hline 1,108 & $\mathbf{G}$ & 80 & 180 & 81 & 2.3 & S & $A$ & 3 & D & 1,835 & 2,037 \\
\hline 1,109 & $\mathbf{G}$ & 80 & 200 & 79 & 2.0 & $S$ & A & 3 & D & 1,848 & 2,051 \\
\hline 1,110 & $\mathbf{G}$ & 80 & 200 & 79 & 2.0 & $\mathrm{~S}$ & A & 5 & D & 1,996 & 2,216 \\
\hline 1,111 & $\mathbf{G}$ & 80 & 200 & 82 & 2.3 & $S$ & A & 3 & D & 1,848 & 2,051 \\
\hline 1,112 & $\mathbf{G}$ & 80 & 200 & 80 & & $S$ & A & 3 & $R$ & 3,207 & 2,117 \\
\hline 1,113 & $\mathbf{G}$ & 80 & 200 & 82 & 2.3 & $\mathrm{~S}$ & A & 3 & $\mathrm{D}$ & 1,848 & 2,051 \\
\hline 1,114 & $\mathbf{G}$ & 80 & 250 & 80 & 2.3 & A & A & 3 & D & 2,428 & 2,695 \\
\hline 1,115 & $\mathbf{G}$ & 80 & 250 & 80 & 2.3 & A & A & 3 & D & 2,428 & 2,695 \\
\hline 1,116 & $\mathbf{G}$ & 80 & 250 & 80 & 2.3 & $S$ & A & 3 & D & 1,972 & 2,189 \\
\hline 1,117 & $\mathbf{G}$ & 80 & 250 & 80 & 2.3 & S & A & 3 & D & 1,972 & 2,189 \\
\hline 1,118 & $\mathbf{G}$ & 80 & 400 & 80 & 2.8 & A & $A$ & 3 & D & 3,481 & 3,864 \\
\hline 1,119 & $\mathbf{G}$ & 80 & 400 & 80 & & $\mathrm{~A}$ & $\mathrm{~A}$ & 3 & $R$ & 5,370 & 3,544 \\
\hline 1,120 & $\mathbf{G}$ & 80 & 400 & 80 & 2.8 & $\mathrm{~S}$ & A & 3 & D & 3,033 & 3,367 \\
\hline 1,121 & $\mathbf{G}$ & 80 & 400 & 80 & & S & A & 3 & $\mathbf{R}$ & 4,812 & 3,176 \\
\hline 1,122 & $\mathbf{G}$ & 80 & 430 & 82 & 1.6 & A & A & 3 & D & 3,650 & 4,052 \\
\hline 1,123 & $\mathbf{G}$ & 80 & 430 & 82 & 1.6 & $A$ & A & 3 & D & 3,653 & 4,055 \\
\hline 1,124 & $\mathbf{G}$ & 80 & 430 & 82 & 1.6 & $\mathrm{~S}$ & A & 3 & D & 3,187 & 3,538 \\
\hline 1,125 & G & 80 & 430 & 82 & 1.6 & S & A & 3 & D & 3,205 & 3,558 \\
\hline 1,126 & $\mathbf{G}$ & 80 & 500 & 77 & 2.7 & $\bar{A}$ & $\mathrm{~A}$ & 3 & $\mathrm{D}$ & 3,950 & 4,385 \\
\hline 1,127 & $G$ & 80 & 500 & 77 & 2.7 & $A$ & $A$ & 5 & $D$ & 4,266 & 4,735 \\
\hline 1,128 & $\mathbf{G}$ & 80 & 500 & 77 & 2.7 & $\mathrm{~S}$ & A & 3 & D & 3,493 & 3,877 \\
\hline 1,129 & $\mathbf{G}$ & 80 & 500 & 77 & 2.7 & $S$ & A & 5 & D & 3,772 & 4,187 \\
\hline 1,130 & $\mathbf{G}$ & 80 & 510 & 81 & 2.3 & $A$ & A & 3 & D & 3,900 & 4,329 \\
\hline 1,131 & $\mathbf{G}$ & 80 & 510 & 78 & 2.0 & A & A & 3 & D & 3,950 & 4,385 \\
\hline 1,132 & $\mathbf{G}$ & 80 & 510 & 81 & 2.3 & $\mathrm{~S}$ & $\mathrm{~A}$ & 3 & D & 3,430 & 3,807 \\
\hline 1,133 & $\mathbf{G}$ & 80 & 510 & 78 & 2.0 & S & A & 3 & D & 3,493 & 3,877 \\
\hline 1.134 & $\mathbf{G}$ & 80 & 510 & 80 & 3.0 & A & $A$ & 3 & D & 3,950 & 4,385 \\
\hline
\end{tabular}


Table A.1. Fuel-Fired Storage Water Heaters (contd)

\begin{tabular}{|c|c|c|c|c|c|c|c|c|c|c|c|}
\hline REC & FUEL & $\mathrm{VOL}$ & INPUT & EFF & STBY & TANK & BURN & WARR & CTYPE & LCOST & Ccost \\
\hline 1,135 & $G$ & 80 & 510 & 80 & & $A$ & A & 3 & $R$ & 6,047 & 3,991 \\
\hline 1,136 & G & 80 & 510 & 80 & 3.0 & S & $A$ & 3 & D & 3,493 & 3,877 \\
\hline 1,137 & G & 80 & 510 & 80 & & S & $\bar{A}$ & 3 & $R$ & 5,255 & 3,468 \\
\hline 1,138 & $G$ & 80 & 730 & 80 & 1.7 & $A$ & A & 3 & D & 4,704 & 5,221 \\
\hline 1,139 & G & 80 & 730 & 78 & 2.5 & $A$ & $A$ & 3 & D & 4,872 & 5,408 \\
\hline 1,140 & $G$ & 80 & 730 & 78 & 2.5 & A & $A$ & 5 & $D$ & 5,262 & 5,841 \\
\hline 1,141 & G & 80 & 730 & 80 & 1.7 & A & A & 3 & D & 4,872 & 5,408 \\
\hline 1,142 & $G$ & 80 & 730 & 80 & & A & A & 3 & $\mathbf{R}$ & 8,173 & 5,394 \\
\hline 1,143 & $G$ & 80 & 730 & 80 & 1.7 & s & A & 3 & D & 4,414 & 4,900 \\
\hline 1,144 & $\bar{G}$ & 80 & 730 & 78 & 2.5 & S & A & 3 & D & 4,414 & 4,900 \\
\hline 1,145 & G & 80 & 730 & 78 & 2.5 & S & A & 5 & D & 4,767 & 5,291 \\
\hline 1,146 & $G$ & 80 & 730 & 80 & 1.7 & S & A & 3 & D & 4,414 & 4,900 \\
\hline 1,147 & $\bar{G}$ & 80 & 730 & 80 & & S & A & 3 & $\mathbf{R}$ & 7,307 & 4,823 \\
\hline 1,148 & $G$ & 80 & 160 & 80 & 2.3 & s & A & 3 & D & 1,793 & 1,990 \\
\hline 1,149 & $\bar{G}$ & 80 & 200 & 79 & 2.0 & $S$ & A & 3 & D & 1,873 & 2,079 \\
\hline 1,150 & 0 & 80 & 320 & 80 & 2.8 & $\bar{A}$ & $\mathrm{P}$ & 3 & D & 3,195 & 3,546 \\
\hline 1,151 & 0 & 80 & 320 & 80 & 2.8 & S & $P$ & 3 & D & 2,373 & 2,634 \\
\hline 1,152 & $G$ & 90 & 200 & 79 & 2.1 & S & A & 3 & D & 1,848 & 2,051 \\
\hline 1,153 & $G$ & 90 & 400 & 83 & 2.6 & $A$ & A & 3 & $D$ & 3,245 & 3,602 \\
\hline 1,154 & $G$ & 90 & 400 & 83 & 2.6 & s & A & 3 & D & 3,049 & 3,384 \\
\hline 1,155 & $G$ & 90 & 140 & & & A & $P$ & 3 & $D$ & 3,466 & 3,847 \\
\hline 1,156 & $\bar{G}$ & 90 & 140 & & & s & $P$ & 3 & D & 2,300 & 2,553 \\
\hline 1,157 & $G$ & 90 & 180 & 80 & 2.5 & s & A & 3 & D & 1,837 & 2,039 \\
\hline 1,158 & $\bar{G}$ & 90 & 200 & & & A & $P$ & 3 & $D$ & 3,519 & 3,906 \\
\hline 1,159 & 0 & 90 & 200 & 81 & 2.8 & $S$ & $P$ & 3 & D & 2,192 & 2,433 \\
\hline 1,160 & G & 90 & 200 & & & s & $P$ & 3 & D & 2,376 & 2,637 \\
\hline 1,161 & 0 & 90 & 250 & 82 & 2.8 & s & $P$ & 3 & D & 2,245 & 2,492 \\
\hline 1,162 & $G$ & 90 & 250 & 83 & 2.4 & $\bar{A}$ & A & 3 & D & 2,571 & 2,854 \\
\hline 1,163 & $G$ & 90 & 250 & 83 & 2.4 & S & A & 3 & D & 2,107 & 2,339 \\
\hline 1,164 & $G$ & 90 & 270 & & & A & $P$ & 3 & $D$ & 3,572 & 3,965 \\
\hline 1,165 & $G$ & 90 & 270 & & & s & $P$ & 3 & D & 2,670 & 2,964 \\
\hline 1,166 & $G$ & 90 & 150 & 78 & 2.5 & s & A & 3 & $D$ & 1,789 & 1,986 \\
\hline 1,167 & $G$ & 90 & 590 & 80 & & $\bar{A}$ & $A$ & 5 & $R$ & 5,585 & 5,585 \\
\hline 1,168 & G & 90 & 200 & 83 & 2.1 & s & A & 3 & $D$ & 1,910 & 2,120 \\
\hline 1,169 & G & 90 & 300 & 81 & 2.4 & $\bar{A}$ & $A$ & 3 & D & 2,650 & 2,942 \\
\hline 1,170 & $G$ & 90 & 300 & 82 & 2.4 & s & A & 3 & $D$ & 2,196 & 2,438 \\
\hline 1,171 & G & 100 & 180 & 81 & 2.2 & S & $A$ & 3 & $D$ & 1,837 & 2,039 \\
\hline 1,172 & $G$ & 100 & 200 & 81 & 1.7 & s & A & 3 & $D$ & 1,897 & 2,106 \\
\hline 1,173 & $G$ & 100 & 200 & 80 & 0.0 & S & A & 3 & $R$ & 3,238 & 2,137 \\
\hline 1,174 & $G$ & 100 & 200 & 81 & 1.7 & s & A & 3 & $D$ & 1,897 & 2,106 \\
\hline 1,175 & $G$ & 100 & 250 & 80 & 1.7 & $A$ & A & 3 & D & 2,560 & 2,842 \\
\hline 1,176 & $\bar{G}$ & 100 & 250 & 80 & 1.7 & A & A & 3 & D & 2,560 & 2,842 \\
\hline 1,177 & $G$ & 100 & 250 & 80 & 1.7 & s & A & 3 & $D$ & 2,104 & 2,335 \\
\hline 1,178 & G & 100 & 250 & 80 & 0.0 & S & A & 3 & $R$ & 3,491 & 2,304 \\
\hline 1,179 & $G$ & 100 & 250 & 80 & 1.7 & s & $A$ & 3 & D & 2,026 & 2,249 \\
\hline
\end{tabular}


Table A.1. Fuel-Fired Storage Water Heaters (contd)

\begin{tabular}{|c|c|c|c|c|c|c|c|c|c|c|c|}
\hline REC & FUEL & VOL & INPUT & EFF & STBY & TANK & BURN & WARR & CTYPE & $\overline{\text { LCOST }}$ & CcosT \\
\hline 1,180 & $\mathbf{G}$ & 100 & 80 & 80 & 3.5 & $S$ & $A$ & 3 & D & 932 & 1,035 \\
\hline 1,181 & $G$ & 100 & 90 & 82 & 2.4 & $S$ & 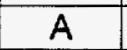 & 3 & D & 931 & 1,033 \\
\hline 1,182 & $\mathbf{G}$ & 100 & 90 & 80 & & $S$ & $A$ & 3 & 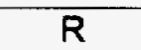 & 1,624 & 1,072 \\
\hline 1,183 & $\mathbf{G}$ & 100 & 100 & & & s & $A$ & 3 & D & 1,181 & 1,311 \\
\hline 1,184 & $\mathbf{G}$ & 100 & 200 & 80 & 2.2 & $S$ & A & 3 & $\bar{D}$ & 1,899 & 2,108 \\
\hline 1,185 & $\mathbf{G}$ & 100 & 200 & 81 & 2.2 & $\mathrm{~S}$ & A & 3 & $\mathrm{D}$ & 1,897 & 2,106 \\
\hline 1,186 & $\mathbf{G}$ & 100 & 200 & 81 & 2.2 & $\bar{S}$ & $\bar{A}$ & 5 & D & 2,049 & 2,274 \\
\hline 1,187 & $\mathbf{G}$ & 100 & 200 & 80 & 1.7 & $\mathrm{~S}$ & A & 3 & $\bar{D}$ & 1,899 & 2,108 \\
\hline 1,188 & $\mathbf{G}$ & 100 & 200 & 80 & 1.9 & $S$ & A & 3 & D & 1,897 & 2,106 \\
\hline 1,189 & $G$ & 100 & 200 & 80 & 1.8 & $S$ & $\bar{A}$ & 3 & D & 1,897 & 2,106 \\
\hline 1,190 & $\mathbf{G}$ & 100 & 200 & 79 & 2.0 & $S$ & A & 3 & D & 1,897 & 2,106 \\
\hline 1,191 & $\mathbf{G}$ & 100 & 200 & 80 & & $S$ & $\bar{A}$ & 3 & $\mathbf{R}$ & 3,238 & 2,137 \\
\hline 1,192 & $\mathbf{G}$ & 100 & 240 & 80 & 2.2 & $A$ & A & 3 & D & 2,562 & 2,844 \\
\hline 1,193 & G & 100 & 240 & 80 & 2.2 & $S$ & A & 3 & D & 2,026 & 2,249 \\
\hline 1,194 & $\mathbf{G}$ & 100 & 250 & 82 & 1.9 & $\bar{A}$ & $\bar{A}$ & 3 & D & 2,560 & 2,842 \\
\hline 1,195 & G & 100 & 250 & 80 & 0.0 & A & A & 3 & $R$ & 4,490 & 2,963 \\
\hline 1,196 & $\mathbf{G}$ & 100 & 250 & 81 & 1.8 & A & A & 3 & $D$ & 2,560 & 2,842 \\
\hline 1,197 & $G$ & 100 & 250 & 82 & 1.9 & S & $A$ & 3 & D & 2,104 & 2,335 \\
\hline 1,198 & $\mathbf{G}$ & 100 & 250 & & & S & A & 3 & D & 2,106 & 2,338 \\
\hline 1,199 & $\mathbf{G}$ & 100 & 250 & 81 & 1.8 & $S$ & A & 3 & D & 2,026 & 2,249 \\
\hline 1,200 & $\mathbf{G}$ & 100 & 260 & 79 & 2.2 & A & $\bar{A}$ & 3 & D & 2,560 & 2,842 \\
\hline 1,201 & $\mathbf{G}$ & 100 & 260 & 79 & 2.2 & $\bar{A}$ & $\bar{A}$ & 5 & $\bar{D}$ & 2,765 & 3,069 \\
\hline 1,202 & $\mathbf{G}$ & 100 & 260 & 79 & 2.2 & $S$ & A & 3 & D & 2,104 & 2,335 \\
\hline 1,203 & $G$ & 100 & 260 & 79 & 2.2 & $S$ & A & 5 & D & 2,272 & 2,522 \\
\hline 1,204 & $G$ & 100 & 270 & 82 & 2.3 & $A$ & A & 3 & $\bar{D}$ & 2,614 & 2,902 \\
\hline 1,205 & $G$ & 100 & 270 & 80 & 1.8 & A & $\bar{A}$ & 3 & $D$ & 2,560 & 2.842 \\
\hline 1,206 & $\mathbf{G}$ & 100 & 270 & 82 & 2.3 & $s$ & A & 3 & D & 2,160 & 2,398 \\
\hline 1,207 & $G$ & 100 & 270 & 80 & 1.8 & $S$ & $\mathrm{~A}$ & 3 & D & 2,104 & 2,335 \\
\hline 1,208 & $\mathbf{G}$ & 100 & 280 & 82 & 1.7 & $s$ & A & 3 & $D$ & 2,170 & 2,409 \\
\hline 1,209 & $G$ & 100 & 300 & 81 & 1.7 & $A$ & A & 3 & D & 2,648 & 2,939 \\
\hline 1,210 & $\mathbf{G}$ & 100 & 300 & 81 & 1.7 & S & A & 3 & D & 2,196 & 2,438 \\
\hline 1,211 & $G$ & 100 & 400 & & & A & A & 3 & D & 3,329 & 3,695 \\
\hline 1,212 & $\mathbf{G}$ & 100 & 400 & & & $\mathrm{~S}$ & A & 3 & $D$ & 3,050 & 3,386 \\
\hline 1,213 & $\mathbf{G}$ & 100 & 400 & 78 & 2.0 & $\bar{A}$ & $\bar{A}$ & 3 & D & 3,491 & 3,875 \\
\hline 1,214 & $\mathbf{G}$ & 100 & 400 & 78 & 2.0 & $A$ & A & 5 & D & 3,770 & 4,185 \\
\hline 1,215 & $\mathbf{G}$ & 100 & 400 & 78 & 2.0 & $\mathrm{~S}$ & A & 3 & $D$ & 3,033 & 3,367 \\
\hline 1,216 & $\mathbf{G}$ & 100 & 400 & 78 & 2.0 & 5 & A & 5 & D & 3,276 & 3,636 \\
\hline 1,217 & $\mathbf{G}$ & 100 & 680 & 80 & & $A$ & A & 5 & $R$ & 6,234 & 6,234 \\
\hline 1,218 & $G$ & 120 & 810 & 80 & & A & A & 5 & $\mathrm{R}$ & 6,955 & 6,955 \\
\hline 1,219 & $\mathbf{G}$ & 140 & 140 & 80 & & $\bar{A}$ & $P$ & 5 & D & $\star$ & 8,220 \\
\hline 1,220 & 0 & 140 & 140 & 80 & & A & $P$ & 5 & $\mathrm{D}$ & * & 7,777 \\
\hline 1,221 & $\mathbf{G}$ & 140 & 200 & 81 & & A & $P$ & 5 & $\bar{D}$ & * & 8,498 \\
\hline 1,222 & 0 & 140 & 200 & 80 & & A & $P$ & 5 & D & * & 8,044 \\
\hline 1,223 & $G$ & 140 & 260 & 81 & & A & $P$ & 5 & $D$ & * & 8,745 \\
\hline 1,224 & 0 & 140 & 260 & 80 & & A & $P$ & 5 & $D$ & * & 8,277 \\
\hline
\end{tabular}


Table A.1. Fuel-Fired Storage Water Heaters (contd)

\begin{tabular}{|c|c|c|c|c|c|c|c|c|c|c|c|}
\hline REC & FUEL & VOL & INPUT & EFF & STBY & TANK & BURN & WARR & CTYPE & LCOST & CCOST \\
\hline 1,225 & $G$ & 140 & 270 & 81 & & $A$ & $\mathbf{P}$ & 5 & D & * & 10,805 \\
\hline 1,226 & 0 & 140 & 270 & 80 & & A & $P$ & 5 & D & * & 10,225 \\
\hline 1,227 & $\mathbf{G}$ & 140 & 400 & 81 & & $\bar{A}$ & $\mathbf{P}$ & 5 & D & * & 11,080 \\
\hline 1,228 & 0 & 140 & 400 & 80 & & A & $P$ & 5 & $D$ & * & 10,485 \\
\hline 1,229 & $\mathbf{G}$ & 140 & 540 & 80 & & $A$ & $P$ & 5 & D & * & 11,595 \\
\hline 1,230 & 0 & 140 & 540 & 80 & & A & $P$ & 5 & $\bar{D}$ & * & 10,970 \\
\hline 1,231 & $\mathbf{G}$ & 140 & 720 & 79 & & $\mathrm{~A}$ & $P$ & 5 & $\bar{D}$ & $\star$ & 11,807 \\
\hline 1,232 & 0 & 140 & 720 & 80 & & $A$ & $P$ & 5 & $D$ & * & 11,174 \\
\hline 1,233 & G & 140 & 1,170 & 80 & & A & $A$ & 5 & $R$ & * & 7,632 \\
\hline 1,234 & $\mathbf{G}$ & 140 & 990 & 80 & & A & A & 5 & $R$ & $\star$ & 7,356 \\
\hline 1,235 & G & 180 & 1,350 & 80 & & A & A & 5 & $R$ & * & 8,882 \\
\hline 1,236 & G & 200 & 1,500 & 80 & 2.4 & A & $P$ & 5 & $\mathrm{D}$ & $\star$ & 19,707 \\
\hline 1,237 & $\mathbf{G}$ & 210 & 1,250 & 80 & 2.4 & A & $P$ & 5 & $\mathrm{D}$ & $\star$ & 18,124 \\
\hline 1,238 & G & 220 & 1,750 & 80 & & $A$ & A & 5 & $\mathrm{R}$ & * & 9,455 \\
\hline 1,239 & G & 220 & 300 & & & $A$ & $P$ & 5 & D & $\star$ & 15,615 \\
\hline 1,240 & 0 & 220 & 300 & 80 & & A & $P$ & 5 & D & * & 14,777 \\
\hline 1,241 & $\mathbf{G}$ & 220 & 600 & & & $\bar{A}$ & $P$ & 5 & D & * & 15,955 \\
\hline 1,242 & 0 & 220 & 600 & 80 & & A & $P$ & 5 & D & * & 16,477 \\
\hline 1,243 & $G$ & 220 & 800 & & & A & $P$ & 5 & D & * & 16,475 \\
\hline 1,244 & 0 & 220 & 800 & 80 & & $A$ & $P$ & 5 & D & * & 15,591 \\
\hline 1,245 & $\mathbf{G}$ & 220 & 1,000 & 80 & 2.4 & A & $P$ & 5 & $\bar{D}$ & $\star$ & 16,886 \\
\hline 1,246 & 0 & 220 & 1,000 & 80 & & A & $P$ & 5 & D & * & 15,980 \\
\hline 1,247 & 0 & 220 & 1,250 & 80 & & $\bar{A}$ & $P$ & 5 & D & * & 17,152 \\
\hline 1,248 & 0 & 220 & 1,500 & 80 & & A & $P$ & 5 & $\bar{D}$ & * & 18,649 \\
\hline 1,249 & $\mathbf{G}$ & 300 & 300 & 79 & & A & $P$ & 5 & $D$ & * & 16,278 \\
\hline 1,250 & $\mathbf{G}$ & 300 & 600 & 79 & & $\bar{A}$ & $P$ & 5 & $D$ & $\star$ & 16,601 \\
\hline 1,251 & $\mathbf{G}$ & 300 & 800 & 80 & & A & $P$ & 5 & D & $\star$ & 17,096 \\
\hline 1,252 & $\mathbf{G}$ & 300 & 1,000 & 78 & & A & $P$ & 5 & D & $\star$ & 17,489 \\
\hline 1,253 & $\mathbf{G}$ & 300 & 1,250 & 79 & & A & $P$ & 5 & D & $\star$ & 18,667 \\
\hline 1,254 & $\mathbf{G}$ & 300 & 1,500 & 79 & & A & $P$ & 5 & D & * & 20,174 \\
\hline 1,255 & $\mathbf{G}$ & 380 & 2,500 & 80 & & $A$ & $P$ & 5 & D & * & 27,187 \\
\hline 1,256 & $\mathbf{G}$ & 390 & 2,250 & 80 & & A & $P$ & 5 & D & * & 26,178 \\
\hline 1,257 & $\mathbf{G}$ & 400 & 2,000 & 80 & & A & $P$ & 5 & D & * & 25,484 \\
\hline 1,258 & $\mathbf{G}$ & 400 & 1,750 & 80 & & A & P & 5 & D & * & 23,554 \\
\hline 1,259 & $\mathbf{G}$ & 410 & 600 & & & A & $P$ & 5 & D & * & 19,906 \\
\hline 1,260 & 0 & 410 & 600 & 80 & & $\bar{A}$ & $P$ & 5 & D & * & 18,837 \\
\hline 1,261 & $G$ & 410 & 800 & & & $\bar{A}$ & $P$ & 5 & D & $\star$ & 19,946 \\
\hline 1,262 & 0 & 410 & 800 & 80 & & $A$ & $P$ & 5 & D & * & 18,876 \\
\hline 1,263 & $G$ & 410 & 1,000 & & & A & $\mathbf{P}$ & 5 & D & * & 21,061 . \\
\hline 1,264 & 0 & 410 & 1,000 & 80 & & A & $P$ & 5 & D & * & 19,930 \\
\hline 1,265 & $\mathbf{G}$ & 410 & 1,250 & & & A & $P$ & 5 & D & * & 21,550 \\
\hline 1,266 & 0 & 410 & 1,250 & 80 & & A & $P$ & 5 & D & * & 20,393 \\
\hline 1,267 & $G$ & 410 & 1,500 & & & A & $P$ & 5 & D & * & 22,971 \\
\hline 1,268 & 0 & 410 & 1,500 & 80 & & A & $P$ & 5 & D & * & 21,737 \\
\hline 1,269 & 0 & 410 & 1,750 & 80 & & A & $P$ & 5 & D & $\star$ & 22,288 \\
\hline
\end{tabular}


Table A.1. Fuel-Fired Storage Water Heaters (contd)

\begin{tabular}{|c|c|c|c|c|c|c|c|c|c|c|c|}
\hline REC & FUEL & VOL & INPUT & EFF & STBY & TANK & BURN & WARR & CTYPE & LCOST & CcosT \\
\hline 1,270 & 0 & 410 & 2,000 & 80 & & $A$ & $P$ & 5 & D & * & 24,116 \\
\hline 1,271 & 0 & 410 & 2,250 & 80 & & $A$ & $P$ & 5 & D & * & 24,772 \\
\hline 1,272 & 0 & 410 & 2,500 & 80 & & $\bar{A}$ & $P$ & 5 & D & * & 25,726 \\
\hline 1,273 & 0 & 580 & 2,250 & 80 & & $\bar{A}$ & $P$ & 5 & $D$ & * & 26,449 \\
\hline 1,274 & $G$ & 580 & 2,500 & 80 & & $\bar{A}$ & $P$ & 5 & $D$ & * & 29,048 \\
\hline 1,275 & 0 & 580 & 2,500 & 80 & & A & $P$ & 5 & D & $\star$ & 27,486 \\
\hline 1,276 & G & 590 & 2,250 & & & A & $P$ & 5 & $D$ & * & 27,948 \\
\hline 1,277 & $\mathbf{G}$ & 590 & 720 & & & $\mathrm{~A}$ & $P$ & 5 & $\bar{D}$ & * & 23,726 \\
\hline 1,278 & 0 & 590 & 720 & 80 & & A & $P$ & 5 & $D$ & * & 22,453 \\
\hline 1,279 & $\mathbf{G}$ & 590 & 1,000 & & & A & $P$ & 5 & $D$ & * & 24,897 \\
\hline 1,280 & 0 & 590 & 1,000 & 80 & & $A$ & $P$ & 5 & D & $\star$ & 23,161 \\
\hline 1,281 & $\mathbf{G}$ & 590 & 1,250 & & & $\bar{A}$ & $P$ & 5 & D & $\star$ & 25,159 \\
\hline 1,282 & 0 & 590 & 1,250 & 80 & & A & $P$ & 5 & $\bar{D}$ & * & 23,878 \\
\hline 1,283 & $\mathbf{G}$ & 590 & 1,500 & & & $\bar{A}$ & $P$ & 5 & $\bar{D}$ & * & 25,851 \\
\hline 1,284 & 0 & 590 & 1,500 & 80 & & A & $P$ & 5 & $D$ & * & 24,463 \\
\hline 1,285 & G & 590 & 1,750 & & & $\mathrm{~A}$ & $\mathbf{P}$ & 5 & D & * & 26,560 \\
\hline 1,286 & 0 & 590 & 1,750 & 80 & & A & $\bar{P}$ & 5 & D & * & 25,135 \\
\hline 1,287 & G & 590 & 2,000 & & & $\bar{A}$ & $\mathbf{P}$ & 5 & D & * & 27,319 \\
\hline 1,288 & 0 & 590 & 2,000 & 80 & & $\mathrm{~A}$ & $P$ & 5 & D & * & 25,847 \\
\hline
\end{tabular}


Table A.2. Tankless Water Heaters

\begin{tabular}{|c|c|c|c|c|c|c|c|c|}
\hline REC & FUEL & INPUT & EFF & $\mathrm{EXCH}$ & WARR & CTYPE & LCOST & CcosT \\
\hline 1,289 & $G$ & 230 & 80 & $C$ & 5 & $R$ & 1,942 & 1,282 \\
\hline 1,290 & $\mathbf{G}$ & 230 & 80 & C & 5 & $\bar{D}$ & 1,531 & 1,684 \\
\hline 1,291 & $G$ & 250 & 88 & C & 5 & $R$ & 7,462 & 4,925 \\
\hline 1,292 & G & 260 & 82 & C & 5 & $R$ & 3,682 & 2,025 \\
\hline 1,293 & $\mathbf{G}$ & 270 & 80 & $C$ & 5 & $\mathbf{R}$ & 2,358 & 1,556 \\
\hline 1,294 & $\mathbf{G}$ & 300 & 82 & C & 5 & $\mathrm{D}$ & 2,064 & 2,270 \\
\hline 1,295 & $\mathbf{G}$ & 300 & 85 & C & 5 & $\mathbf{R}$ & 3,998 & 2,639 \\
\hline 1,296 & $G$ & 320 & 80 & C & 5 & $R$ & 2,883 & 1,903 \\
\hline 1,297 & $G$ & 330 & 82 & C & 5 & $D$ & 2,724 & 2,996 \\
\hline 1,298 & $G$ & 330 & 82 & C & 5 & $D$ & 2,615 & 2,877 \\
\hline 1,299 & $G$ & 330 & 82 & C & 5 & $R$ & 4,035 & 2,219 \\
\hline 1,300 & $\mathbf{G}$ & 360 & 80 & C & 5 & $\bar{R}$ & 2,991 & 1,974 \\
\hline 1,301 & $\mathbf{G}$ & 400 & 82 & C & 5 & $D$ & 2,866 & 3,152 \\
\hline 1,302 & $\mathbf{G}$ & 400 & 80 & c & 5 & $R$ & 3,312 & 2,186 \\
\hline 1,303 & $G$ & 400 & 81 & C & 5 & $\bar{D}$ & 2,516 & 2,768 \\
\hline 1,304 & $\mathbf{G}$ & 400 & 82 & C & 5 & $D$ & 2,762 & 3,038 \\
\hline 1,305 & $G$ & 400 & 82 & 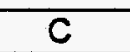 & 5 & $R$ & 4,166 & 2,291 \\
\hline 1,306 & $\mathbf{G}$ & 400 & 85 & C & 5 & $\bar{R}$ & 5,325 & 3,515 \\
\hline 1,307 & $G$ & 420 & 82 & $c$ & 5 & $D$ & 2,516 & 2,768 \\
\hline 1,308 & $\mathbf{G}$ & 500 & 80 & c & 5 & $R$ & 3,917 & 2,585 \\
\hline 1,309 & $\bar{G}$ & 500 & 85 & C & 5 & $R$ & 6,011 & 3,967 \\
\hline 1,310 & $G$ & 500 & 88 & C & 5 & $\bar{R}$ & 9,942 & 6,562 \\
\hline 1,311 & $G$ & 500 & 88 & C & 5 & D & 6,604 & 7,264 \\
\hline 1,312 & $\mathbf{G}$ & 510 & 82 & C & 5 & $\bar{D}$ & 3,543 & 3,898 \\
\hline 1,313 & $\mathbf{G}$ & 510 & 82 & C & 5 & $D$ & 3,404 & 3,745 \\
\hline 1,314 & $\mathbf{G}$ & 510 & 82 & C & 5 & $R$ & 5,644 & 3,104 \\
\hline 1,315 & $\mathbf{G}$ & 520 & 82 & C & 5 & $D$ & 2,895 & 3,185 \\
\hline 1,316 & $\mathbf{G}$ & 630 & 82 & C & 5 & $D$ & 3,826 & 4,208 \\
\hline 1,317 & $\mathbf{G}$ & 630 & 82 & C & 5 & $D$ & 3,686 & 4,054 \\
\hline 1,318 & $G$ & 630 & 82 & $\bar{c}$ & 5 & $\bar{R}$ & 6,131 & 3,372 \\
\hline 1,319 & $G$ & 650 & 85 & c & 5 & $R$ & 6,390 & 4,217 \\
\hline 1,320 & $G$ & 670 & 80 & $c$ & 5 & $R$ & 4,687 & 3,093 \\
\hline 1,321 & G & 670 & 75 & C & 5 & $D$ & 3,309 & 3,640 \\
\hline 1,322 & $\mathbf{G}$ & 720 & 82 & C & 5 & D. & 2,835 & 3,119 \\
\hline 1,323 & G & 730 & 82 & C & 5 & $D$ & 4,085 & 4,494 \\
\hline 1,324 & $G$ & 730 & 82 & C & 5 & $D$ & 3,920 & 4,312 \\
\hline 1,325 & $G$ & 730 & 82 & C & 5 & $R$ & 6,539 & 3,596 \\
\hline 1,326 & $G$ & 750 & 85 & C & 5 & $R$ & 6,639 & 4,382 \\
\hline 1,327 & $G$ & 750 & 88 & $C$ & 5 & $R$ & 10,950 & 7,227 \\
\hline 1,328 & $\mathbf{G}$ & 750 & 88 & C & 5 & $\bar{D}$ & 7,097 & 7,807 \\
\hline 1,329 & $\mathbf{G}$ & 750 & 99 & $\bar{D}$ & & $R$ & $\star$ & $\star$ \\
\hline 1,330 & $\bar{G}$ & 760 & 80 & C & 5 & $R$ & 4,851 & 3,202 \\
\hline 1,331 & $\mathbf{G}$ & 830 & 82 & C & 5 & $D$ & 4,380 & 4,818 \\
\hline 1,332 & $\bar{G}$ & 830 & 82 & C & 5 & $D$ & 4,217 & 4,639 \\
\hline 1,333 & $G$ & 830 & 82 & C & 5 & $R$ & 7,049 & 3,877 \\
\hline
\end{tabular}


Table A.2. Tankless Water Heaters (contd)

\begin{tabular}{|c|c|c|c|c|c|c|c|c|}
\hline REC & FUEL & INPUT & EFF & $\mathrm{EXCH}$ & WARR & CTYPE & LCOST & CCOST \\
\hline 1,334 & $G$ & 840 & 82 & $C$ & 5 & $D$ & 3,060 & 3,366 \\
\hline 1,335 & $\mathbf{G}$ & 930 & 82 & $C$ & 5 & D & 4,596 & 5,056 \\
\hline 1,336 & $\mathbf{G}$ & 940 & 80 & C & 5 & $\mathbf{R}$ & 5,469 & 3,610 \\
\hline 1,337 & $G$ & 960 & 82 & C & 5 & D & 3,195 & 3,515 \\
\hline 1,338 & $\mathbf{G}$ & 960 & 82 & C & 5 & D & 4,617 & 5,078 \\
\hline 1,339 & $\mathbf{G}$ & 960 & 82 & C & 5 & $\mathbf{R}$ & 7,380 & 4,059 \\
\hline 1,340 & $\mathbf{G}$ & 990 & 85 & C & 5 & $\mathrm{R}$ & 7,728 & 5,100 \\
\hline 1,341 & $\mathbf{G}$ & 1,000 & 88 & C & 5 & $R$ & 11,692 & 7,717 \\
\hline 1,342 & $\mathbf{G}$ & 1,000 & 88 & C & 5 & $D$ & 7,426 & 8,169 \\
\hline 1,343 & $\mathbf{G}$ & 1,000 & 93 & $N$ & 5 & $R$ & 14,000 & * \\
\hline 1,344 & G & 1,080 & 82 & $c$ & 5 & D & 3,375 & 3,713 \\
\hline 1,345 & $\mathbf{G}$ & 1,080 & 82 & C & 5 & D & 4,956 & 5,451 \\
\hline 1,346 & $G$ & 1,120 & 82 & C & 5 & D & 4,771 & 5,248 \\
\hline 1,347 & $\mathbf{G}$ & 1,120 & 82 & C & 5 & $R$ & 7,734 & 4,254 \\
\hline 1,348 & $\mathbf{G}$ & 1,180 & 82 & C & 5 & D & 5,273 & 5,800 \\
\hline 1,349 & $G$ & 1,200 & 99 & D & & $\mathrm{R}$ & * & * \\
\hline 1,350 & $\mathbf{G}$ & 1,210 & 80 & C & 5 & $R$ & 6,206 & 4,096 \\
\hline 1,351 & $\mathbf{G}$ & 1,210 & 82 & C & 5 & D & 3,600 & 3,960 \\
\hline 1,352 & $\mathbf{G}$ & 1,220 & 82 & C & 5 & D & 5,086 & 5,595 \\
\hline 1,353 & G & 1,220 & 82 & C & 5 & $\mathrm{R}$ & 8,720 & 4,796 \\
\hline 1,354 & $\mathbf{G}$ & 1,240 & 80 & C & 5 & D & 6,046 & 6,651 \\
\hline 1,355 & $\mathbf{G}$ & 1,260 & 85 & C & 5 & $R$ & 9,037 & 5,964 \\
\hline 1,356 & $G$ & 1,290 & 82 & C & 5 & D & 5,443 & 5,987 \\
\hline 1,357 & $G$ & 1,340 & 82 & C & 5 & $D$ & 5,443 & 5,987 \\
\hline 1,358 & $\mathbf{G}$ & 1,340 & 82 & C & 5 & $R$ & 9,621 & 5,292 \\
\hline 1,359 & G & 1,340 & 76 & C & 5 & $\mathrm{D}$ & 6,519 & 7,171 \\
\hline 1,360 & $G$ & 1,350 & 82 & C & 5 & D & 3,960 & 4,356 \\
\hline 1,361 & $G$ & 1,410 & 82 & C & 5 & D & 5,822 & 6,404 \\
\hline 1,362 & G & 1,440 & 85 & C & 5 & $R$ & 9,790 & 6,461 \\
\hline 1,363 & $G$ & 1,470 & 82 & C & 5 & D & 5,822 & 6,404 \\
\hline 1,364 & $G$ & 1,470 & 82 & C & 5 & $\mathrm{R}$ & 10,137 & 5,575 \\
\hline 1,365 & $G$ & 1,480 & 82 & C & 5 & D & 4,095 & 4,505 \\
\hline 1,366 & $G$ & 1,540 & 80 & $C$ & 5 & $R$ & 7,366 & 4,862 \\
\hline 1,367 & $\mathbf{G}$ & 1,570 & 82 & C & 5 & D & 6,086 & 6,695 \\
\hline 1,368 & $G$ & 1,610 & 82 & C & 5 & D & 4,322 & 4,754 \\
\hline 1,369 & $\mathbf{G}$ & 1,630 & 82 & C & 5 & D & 6,086 & 6,695 \\
\hline 1,370 & $G$ & 1,630 & 82 & C & 5 & $\mathrm{R}$ & 11,629 & 6,396 \\
\hline 1,371 & $\mathbf{G}$ & 1,690 & 80 & C & 5 & $\mathrm{R}$ & 7,987 & 5,271 \\
\hline 1,372 & $\mathbf{G}$ & 1,760 & 82 & C & 5 & D & 6,606 & 7,266 \\
\hline 1,373 & $\mathbf{G}$ & 1,800 & 85 & C & 5 & $R$ & 10,405 & 6,867 \\
\hline 1,374 & $\mathbf{G}$ & 1,810 & 82 & C & 5 & D & 4,950 & 5,445 \\
\hline 1,375 & $G$ & 1,830 & 82 & $C$ & 5 & D & 6,606 & 7,266 \\
\hline 1,376 & $\mathrm{G}$ & 1,830 & 82 & C & 5 & $R$ & 10,329 & 5,681 \\
\hline 1,377 & $\mathbf{G}$ & 2,000 & 99 & D & & $R$ & $\star$ & $\star$ \\
\hline 1,378 & $\mathbf{G}$ & 2,000 & 80 & C & 5 & $\mathrm{R}$ & 9,757 & 6,440 \\
\hline
\end{tabular}


Table A.2. Tankless Water Heaters (contd)

\begin{tabular}{|c|c|c|c|c|c|c|c|c|}
\hline REC & FUEL & INPUT & EFF & $\mathrm{EXCH}$ & WARR & CTYPE & LCOST & CCOST \\
\hline 1,379 & $\mathbf{G}$ & 2,070 & 85 & C & 5 & $\mathrm{R}$ & 13,553 & 8,945 \\
\hline 1,380 & G & 2,100 & 82 & $\mathrm{C}$ & 5 & $\mathbf{R}$ & 12,666 & 6,966 \\
\hline 1,381 & G & 2,310 & 80 & $C$ & 5 & $R$ & 10,191 & 6,726 \\
\hline 1,382 & $\mathbf{G}$ & 2,500 & 82 & C & 5 & $\mathbf{R}$ & 13,528 & 7,440 \\
\hline 1,383 & G & 2,620 & 80 & $\mathrm{C}$ & 5 & $\mathbf{R}$ & 11,319 & 7,471 \\
\hline 1,384 & G & 3,000 & 82 & C & 5 & $\mathbf{R}$ & 16,115 & 8,863 \\
\hline 1,385 & $G$ & 3,000 & 99 & D & & $\mathbf{R}$ & $\star$ & ${ }^{*}$ \\
\hline 1,386 & $G$ & 3,080 & 80 & C & 5 & $\mathrm{R}$ & 12,435 & 8,207 \\
\hline 1,387 & $G$ & 3,500 & 82 & $C$ & 5 & $R$ & 17,517 & 9,634 \\
\hline 1,388 & G & 4,000 & 82 & C & 5 & $\mathbf{R}$ & 18,921 & 10,407 \\
\hline 1,389 & G & 4,500 & 99 & $\mathrm{D}$ & & $\mathbf{R}$ & ${ }^{*}$ & * \\
\hline 1,390 & $G$ & 5,500 & 99 & $D$ & & $\mathrm{R}$ & * & * \\
\hline 1,391 & $\mathbf{G}$ & 7,000 & 99 & D & & $\mathrm{R}$ & * & * \\
\hline 1,392 & G & 9,000 & 99 & $D$ & & $\mathrm{R}$ & * & * \\
\hline 1,393 & $G$ & 12,000 & 99 & D & & $\mathrm{R}$ & $\star$ & * \\
\hline 1,394 & G & 15,000 & 99 & $D$ & & $\mathrm{R}$ & $*$ & * \\
\hline 1,395 & $G$ & 18,000 & 99 & D & & $\mathrm{R}$ & * & * \\
\hline 1,396 & $\mathbf{G}$ & 21,000 & 99 & $D$ & & $\mathbf{R}$ & * & * \\
\hline
\end{tabular}


Table A.3. Electric Storage Water Heaters

\begin{tabular}{|c|c|c|c|c|c|c|c|c|c|c|c|}
\hline REC & VOL & INP & STBY & VOLT & TANK & RVAL & WARR & THERMI & CTYPE & LCOST & CCOST \\
\hline 1,397 & 10 & 15 & & 120 & $\mathbf{S}$ & & 3 & 1 & D & 813 & 902 \\
\hline 1,398 & 10 & 18 & & 120 & $S$ & & 3 & 1 & D & 845 & 938 \\
\hline 1,399 & 10 & 24 & & 120 & $S$ & & 3 & 1 & D & 1,159 & 1,286 \\
\hline 1,400 & 10 & 27 & & 120 & 5 & & 3 & 1 & D & 1,222 & 1,356 \\
\hline 1,401 & 10 & 30 & & 120 & $S$ & & 3 & $T$ & $D$ & 1,230 & 1,365 \\
\hline 1,402 & 10 & 36 & & 120 & 5 & & 3 & 1 & $D$ & 1,274 & 1,414 \\
\hline 1,403 & 10 & 45 & & 120 & $S$ & & 3 & 1 & $\bar{D}$ & 1,433 & 1,591 \\
\hline 1,404 & 10 & 54 & & 120 & $S$ & & 3 & 1 & $D$ & 1,569 & 1,742 \\
\hline 1,405 & 20 & 15 & 1.1 & 240 & $A$ & 16 & 3 & 1 & $D$ & 1,267 & 1,406 \\
\hline 1,406 & 20 & 18 & 1.1 & 240 & $\bar{A}$ & 16 & 3 & 1 & $\bar{D}$ & 1,306 & 1,450 \\
\hline 1,407 & 30 & 15 & & 240 & $\bar{A}$ & 16 & 3 & 1 & D & 1,289 & 1,431 \\
\hline 1,408 & 30 & 18 & & 240 & A & 16 & 3 & 1 & $\bar{D}$ & 1,353 & 1,502 \\
\hline 1,409 & 30 & 24 & & 240 & $A$ & 16 & 3 & 1 & D & 1,725 & 1,915 \\
\hline 1,410 & 40 & 15 & & 240 & $\bar{A}$ & 16 & 3 & $T$ & $D$ & 1,342 & 1,490 \\
\hline 1,411 & 40 & 18 & & 240 & $\bar{A}$ & 16 & 3 & 1 & $D$ & 1,385 & 1,537 \\
\hline 1,412 & 40 & 24 & & 240 & $\bar{A}$ & 16 & 3 & 1 & D & 1,759 & 1,952 \\
\hline 1,413 & 40 & 30 & & 240 & $\mathrm{~A}$ & 16 & 3 & 1 & 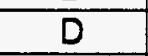 & 1,910 & 2,120 \\
\hline 1,414 & 40 & 36 & & 240 & $\bar{A}$ & 16 & 3 & 1 & D & 2,069 & 2,297 \\
\hline 1,415 & 50 & 14 & 0.9 & 240 & $S$ & 24 & 3 & 1 & $D$ & 1,150 & 1,277 \\
\hline 1,416 & 50 & 14 & 0.9 & 240 & $S$ & 24 & 3 & $S$ & D & 846 & 939 \\
\hline 1,417 & 50 & 15 & 0.8 & 240 & $A$ & 24 & 3 & 1 & D & 1,434 & 1,591 \\
\hline 1,418 & 50 & 15 & & 240 & A & 16 & 3 & 1 & D & 1,430 & 1,587 \\
\hline 1,419 & 50 & 15 & 0.8 & 240 & A & 24 & 3 & S & $\bar{D}$ & 1,132 & 1,256 \\
\hline 1,420 & 50 & 15 & 0.8 & 240 & s & 24 & 3 & 1 & D & 1,145 & 1,271 \\
\hline 1,421 & 50 & 15 & 0.9 & 240 & $\bar{s}$ & 24 & 3 & 1 & $\bar{D}$ & 1,150 & 1,277 \\
\hline 1,422 & 50 & 15 & & 240 & $S$ & & & 1 & $\mathbf{R}$ & 1,257 & 1,068 \\
\hline 1,423 & 50 & 15 & & 240 & $S$ & & 5 & $T$ & $\bar{R}$ & 1,163 & 989 \\
\hline 1,424 & 50 & 15 & 0.9 & 240 & S & 25 & 3 & 1 & D & 1,145 & 1,271 \\
\hline 1,425 & 50 & 15 & 0.8 & 240 & $\bar{s}$ & 24 & 3 & $\bar{s}$ & $\bar{D}$ & 843 & 936 \\
\hline 1,426 & 50 & 15 & 0.9 & 240 & S & 24 & 3 & $S$ & $D$ & 846 & 939 \\
\hline 1,427 & 50 & 15 & 0.9 & 240 & $S$ & 25 & 3 & $S$ & $\bar{D}$ & 843 & 936 \\
\hline 1,428 & 50 & 18 & 0.8 & 240 & $A$ & 24 & 3 & 1 & $\bar{D}$ & 1,439 & 1,597 \\
\hline 1,429 & 50 & 18 & & 240 & $\bar{A}$ & 16 & 3 & 1 & D & 1,467 & 1,628 \\
\hline 1,430 & 50 & 18 & 0.8 & 240 & $A$ & 24 & 3 & $S$ & $D$ & 1,143 & 1,268 \\
\hline 1,431 & 50 & 18 & 0.8 & 240 & $S$ & 24 & 3 & $T$ & D & 1,150 & 1,277 \\
\hline 1,432 & 50 & 18 & 0.9 & 240 & $S$ & 24 & 3 & 1 & $\bar{D}$ & 1,158 & 1,285 \\
\hline 1,433 & 50 & 18 & 0.9 & 240 & $S$ & 25 & 3 & 1 & D & 1,150 & 1,277 \\
\hline 1,434 & 50 & 18 & 0.8 & 240 & $\mathrm{~S}$ & 24 & 3 & S & $D$ & 854 & 948 \\
\hline 1,435 & 50 & 18 & 0.9 & 240 & $\bar{S}$ & 24 & 3 & $S$ & D & 854 & 948 \\
\hline 1,436 & 50 & 18 & 0.9 & 240 & 5 & 25 & 3 & $S$ & $D$ & 854 & 948 \\
\hline 1,437 & 50 & 20 & & 240 & $S$ & & & 1 & $R$ & 1,265 & 1,075 \\
\hline 1,438 & 50 & 20 & & 240 & $\mathrm{~s}$ & & 5 & 1 & $\mathbf{R}$ & 1,171 & 995 \\
\hline 1,439 & 50 & 24 & 0.8 & 240 & $A$ & 24 & 3 & 1 & $D$ & 1,789 & 1,986 \\
\hline 1,440 & 50 & 24 & & 240 & $A$ & 16 & 3 & 1 & $\bar{D}$ & 1,906 & 2,116 \\
\hline 1,441 & 50 & 24 & 0.8 & 240 & $\mathrm{~A}$ & 24 & 3 & $\bar{s}$ & $\mathrm{D}$ & 1,528 & 1,696 \\
\hline
\end{tabular}


Table A.3. Electric Storage Water Heaters (contd)

\begin{tabular}{|c|c|c|c|c|c|c|c|c|c|c|c|}
\hline REC & VOL & INP & STBY & VOLT & TANK & RVAL & WARR & THERM & CTYPE & LCOST & CCOST \\
\hline 1,442 & 50 & 24 & 0.8 & 240 & $\mathrm{~S}$ & 24 & 3 & 1 & $\mathrm{D}$ & 1,500 & 1,665 \\
\hline 1,443 & 50 & 24 & 0.9 & 240 & S & 24 & 3 & I & D & 1,514 & 1,681 \\
\hline 1,444 & 50 & 24 & & 240 & $S$ & & & $I$ & $\mathbf{R}$ & 1,588 & 1,350 \\
\hline 1,445 & 50 & 24 & & 240 & $S$ & & 5 & 1 & $\mathrm{R}$ & 1,494 & 1,270 \\
\hline 1,446 & 50 & 24 & 0.9 & 240 & $S$ & 25 & 3 & 1 & D & 1,500 & 1,665 \\
\hline 1,447 & 50 & 24 & 0.8 & 240 & $S$ & 24 & 3 & $S$ & D & 1,239 & 1,375 \\
\hline 1,448 & 50 & 24 & 0.9 & 240 & $S$ & 24 & 3 & $S$ & D & 1,237 & 1,373 \\
\hline 1,449 & 50 & 24 & 0.9 & 240 & S & 25 & 3 & $S$ & D & 1,239 & 1,375 \\
\hline 1,450 & 50 & 27 & 0.8 & 240 & $\bar{A}$ & 24 & 3 & 1 & D & 1,829 & 2,030 \\
\hline 1,451 & 50 & 27 & 0.8 & 240 & A & 24 & 3 & $\mathrm{~S}$ & D & 1,545 & 1,715 \\
\hline 1,452 & 50 & 27 & 0.8 & 240 & $S$ & 24 & 3 & $T$ & $\mathrm{D}$ & 1,540 & 1,709 \\
\hline 1,453 & 50 & 27 & 0.9 & 240 & $S$ & 24 & 3 & 1 & D & 1,548 & 1,718 \\
\hline 1,454 & 50 & 27 & 0.9 & 240 & S & 25 & 3 & 1 & D & 1,540 & 1,709 \\
\hline 1,455 & 50 & 27 & 0.8 & 240 & $S$ & 24 & 3 & $S$ & $\mathrm{D}$ & 1,256 & 1,394 \\
\hline 1,456 & 50 & 27 & 0.9 & 240 & $S$ & 24 & 3 & $S$ & D & 1,255 & 1,393 \\
\hline 1,457 & 50 & 27 & 0.9 & 240 & $S$ & 25 & 3 & S & D & 1,255 & 1,393 \\
\hline 1,458 & 50 & 30 & 0.8 & 240 & $A$ & 24 & 3 & 1 & D & 1,879 & 2,085 \\
\hline 1,459 & 50 & 30 & & 240 & $\bar{A}$ & 16 & 3 & I & D & 2,022 & 2,244 \\
\hline 1,460 & 50 & 30 & 0.8 & 240 & $A$ & 24 & 3 & $S$ & D & 1,565 & 1,737 \\
\hline 1,461 & 50 & 30 & 0.8 & 240 & $S$ & 24 & 3 & 1 & D & 1,590 & 1,765 \\
\hline 1,462 & 50 & 30 & 0.9 & 240 & $S$ & 24 & 3 & I & D & 1,595 & 1,770 \\
\hline 1,463 & 50 & 30 & & 240 & $S$ & & & 1 & R & 1,654 & 1,406 \\
\hline 1,464 & 50 & 30 & & 240 & S & & 5 & 1 & $\mathbf{R}$ & 1,560 & 1,326 \\
\hline 1,465 & 50 & 30 & 0.9 & 240 & S & 25 & 3 & 1 & D & 1,590 & 1,765 \\
\hline 1,466 & 50 & 30 & 0.8 & 240 & $S$ & 24 & 3 & $\bar{S}$ & D & 1,276 & 1,416 \\
\hline 1,467 & 50 & 30 & 0.9 & 240 & $S$ & 24 & 3 & $S$ & D & 1,275 & 1,415 \\
\hline 1,468 & 50 & 30 & 0.9 & 240 & $S$ & 25 & 3 & $S$ & D & 1,276 & 1,416 \\
\hline 1,469 & 50 & 35 & & 240 & $S$ & & & 1 & $\mathrm{R}$ & 1,824 & 1,550 \\
\hline 1,470 & 50 & 35 & & 240 & S & & 5 & 1 & $\bar{R}$ & 1,730 & 1,471 \\
\hline 1,471 & 50 & 36 & 0.8 & 240 & A & 24 & 3 & 1 & $D$ & 1,929 & 2,141 \\
\hline 1,472 & 50 & 36 & & 240 & A & 16 & 3 & 1 & $D$ & 2,081 & 2,310 \\
\hline 1,473 & 50 & 36 & 0.8 & 240 & A & 24 & 3 & $S$ & $D$ & 1,588 & 1,762 \\
\hline 1,474 & 50 & 36 & 0.8 & 240 & $S$ & 24 & 3 & 1 & D & 1,640 & 1,820 \\
\hline 1,475 & 50 & 36 & 0.9 & 240 & $S$ & 24 & 3 & 1 & $D$ & 1,642 & 1,823 \\
\hline 1,476 & 50 & 36 & 0.9 & 240 & $S$ & 25 & 3 & 1 & D & 1,640 & 1,820 \\
\hline 1,477 & 50 & 36 & 0.8 & 240 & $S$ & 24 & 3 & $S$ & D & 1,299 & 1,442 \\
\hline 1,478 & 50 & 36 & 0.9 & 240 & S & 24 & 3 & $S$ & D & 1,295 & 1,437 \\
\hline 1,479 & 50 & 36 & 0.9 & 240 & $S$ & 25 & 3 & $S$ & D & 1,296 & 1,439 \\
\hline 1,480 & 50 & 40 & & 240 & S & & & 1 & $R$ & 1,833 & 1,558 \\
\hline 1,481 & 50 & 40 & & 240 & $S$ & & 5 & $\mathrm{~T}$ & $\mathbf{R}$ & 1,739 & 1,478 \\
\hline 1,482 & 50 & 45 & 0.8 & 240 & A & 24 & 3 & 1 & D & 2,309 & 2,563 \\
\hline 1,483 & 50 & 45 & & 240 & A & 16 & 3 & $T$ & $D$ & 2,463 & 2,734 \\
\hline 1,484 & 50 & 45 & 0.8 & 240 & $S$ & 24 & 3 & 1 & D & 2,020 & 2,242 \\
\hline 1,485 & 50 & 45 & 0.9 & 240 & $S$ & 24 & 3 & 1 & D & 2,010 & 2,231 \\
\hline 1,486 & 50 & 45 & & 240 & $S$ & & & 1 & $R$ & 1,833 & 1,558 \\
\hline
\end{tabular}


Table A.3. Electric Storage Water Heaters (contd)

\begin{tabular}{|c|c|c|c|c|c|c|c|c|c|c|c|}
\hline REC & VOL & INP & STBY & VOLT & TANK & RVAL & WARR & THERM & CTYPE & LCOST & CCOST \\
\hline 1,487 & 50 & 45 & & 240 & $S$ & & 5 & 1 & $\mathrm{R}$ & 1,739 & 1,478 \\
\hline 1,488 & 50 & 45 & 0.9 & 240 & $S$ & 25 & 3 & 1 & $D$ & 2,010 & 2,231 \\
\hline 1,489 & 50 & 45 & 0.9 & 240 & S & 24 & 3 & $\mathrm{~S}$ & $\mathrm{D}$ & 1,668 & 1,851 \\
\hline 1,490 & 50 & 45 & 0.9 & 240 & $S$ & 25 & 3 & $S$ & D & 1,317 & 1,462 \\
\hline 1,491 & 50 & 48 & & 240 & $S$ & & & 1 & $\mathbf{R}$ & 2,481 & 2,109 \\
\hline 1,492 & 50 & 48 & & 240 & $\mathrm{~S}$ & & 5 & 1 & $\mathbf{R}$ & 2,387 & 2,029 \\
\hline 1,493 & 50 & 54 & $0.8^{\circ}$ & 240 & $A$ & 24 & 3 & 1 & $D$ & 2,379 & 2,640 \\
\hline 1,494 & 50 & 54 & 0.8 & 240 & $S$ & 24 & 3 & 1 & $D$ & 2,090 & 2,320 \\
\hline 1,495 & 50 & 54 & 0.9 & 240 & $S$ & 24 & 3 & 1 & $D$ & 2,084 & 2,313 \\
\hline 1,496 & 50 & 54 & & 240 & $S$ & & & 1 & $R$ & 2,499 & 2,124 \\
\hline 1,497 & 50 & 54 & & 240 & $S$ & & 5 & 1 & $\mathbf{R}$ & 2,405 & 2,044 \\
\hline 1,498 & 50 & 54 & 0.9 & 240 & $S$ & 25 & 3 & 1 & $D$ & 2,083 & 2,312 \\
\hline 1,499 & 50 & 54 & 0.9 & 240 & $\mathrm{~S}$ & 24 & 3 & $S$ & D & 1,683 & 1,868 \\
\hline 1,500 & 50 & 54 & 0.9 & 240 & 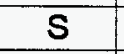 & 25 & 3 & $S$ & $D$ & 1,339 & 1,486 \\
\hline 1,501 & 50 & 58 & & 240 & $S$ & & & 1 & $\mathrm{R}$ & 2,508 & 2,132 \\
\hline 1,502 & 50 & 58 & & 240 & $S$ & & 5 & 1 & $\mathrm{R}$ & 2,414 & 2,052 \\
\hline 1,503 & 50 & 14 & & 240 & $S$ & 16 & 5 & 1 & D & 1,375 & 1,526 \\
\hline 1,504 & 50 & 14 & & 240 & $S$ & 16 & 3 & 1 & D & 1,150 & 1,277 \\
\hline 1,505 & 50 & 14 & 0.9 & 240 & $S$ & 20 & 3 & 1 & D & 1,156 & 1,283 \\
\hline 1,506 & 50 & 14 & & 240 & $S$ & 16 & 5 & $S$ & D & 1,071 & 1,189 \\
\hline 1,507 & 50 & 14 & & 240 & S & 16 & 3 & $S$ & D & 846 & 939 \\
\hline 1,508 & 50 & 14 & 0.9 & 240 & $S$ & 20 & 3 & $S$ & D & 843 & 936 \\
\hline 1,509 & 50 & 15 & & 240 & S & 16 & 5 & 1 & $D$ & 1,375 & 1,526 \\
\hline 1,510 & 50 & 15 & & 240 & $S$ & 16 & 3 & 1 & $D$ & 1,150 & 1,277 \\
\hline 1,511 & 50 & 15 & 0.9 & 240 & $S$ & 20 & 3 & 1 & D & 1,151 & 1,278 \\
\hline 1,512 & 50 & 15 & & 240 & $S$ & 16 & 5 & $S$ & $\bar{D}$ & 1,071 & 1,189 \\
\hline 1,513 & 50 & 15 & & 240 & $S$ & 16 & 3 & $S$ & D & 846 & 939 \\
\hline 1,514 & 50 & 15 & 0.9 & 240 & $S$ & 20 & 3 & $S$ & D & 843 & 936 \\
\hline 1,515 & 50 & 18 & & 240 & $S$ & 16 & 5 & $\mathrm{I}$ & D & 1,383 & 1,535 \\
\hline 1,516 & 50 & 18 & & 240 & $S$ & 16 & 3 & 1 & D & 1,158 & 1,285 \\
\hline 1,517 & 50 & 18 & 0.9 & 240 & $\mathrm{~S}$ & 20 & 3 & 1 & D & 1,159 & 1,286 \\
\hline 1,518 & 50 & 18 & & 240 & $S$ & 24 & 3 & 1 & $\mathbf{R}$ & 1,884 & 1,198 \\
\hline 1,519 & 50 & 18 & & 480 & $S$ & 24 & 3 & 1 & $R$ & 2,077 & 1,321 \\
\hline 1,520 & 50 & 18 & & 240 & $S$ & 16 & 5 & $S$ & $D$ & 1,079 & 1,198 \\
\hline 1,521 & 50 & 18 & & 240 & $S$ & 16 & 3 & $S$ & D & 854 & 948 \\
\hline 1,522 & 50 & 18 & 0.9 & 240 & $S$ & 20 & 3 & $S$ & $D$ & 854 & 948 \\
\hline 1,523 & 50 & 18 & & 240 & $S$ & 24 & 3 & $S$ & $\mathrm{R}$ & 1,456 & 926 \\
\hline 1,524 & 50 & 18 & & 480 & $S$ & 24 & 3 & $S$ & $R$ & 1,574 & 1,001 \\
\hline 1,525 & 50 & 24 & 0.9 & 240 & $S$ & 20 & 3 & 1 & $\mathrm{D}$ & 1,514 & 1,681 \\
\hline 1,526 & 50 & 24 & 0.9 & 240 & $S$ & 20 & 3 & $S$ & $D$ & 1,239 & 1,375 \\
\hline 1,527 & 50 & 27 & & 240 & s & 16 & 5 & 1 & D & 1,773 & 1,968 \\
\hline 1,528 & 50 & 27 & & 240 & $S$ & 16 & 3 & 1 & $D$ & 1,548 & 1,718 \\
\hline 1,529 & 50 & 27 & 0.9 & 240 & $S$ & 20 & 3 & 1 & $D$ & 1,549 & 1,719 \\
\hline 1,530 & 50 & 27 & & 240 & $S$ & 24 & 3 & 1 & $R$ & 2,673 & 1,700 \\
\hline 1,531 & 50 & 27 & & 480 & $S$ & 24 & 3 & 1 & $\mathrm{R}$ & 2,808 & 1,786 \\
\hline
\end{tabular}


Table A.3. Electric Storage Water Heaters (contd)

\begin{tabular}{|c|c|c|c|c|c|c|c|c|c|c|c|}
\hline REC & VOL & INP & STBY & VOLT & TANK & RVAL & WARR & THERM & CTYPE & LCOST & CCOST \\
\hline 1,532 & 50 & 27 & & 240 & $\mathrm{~S}$ & 16 & 5 & $\mathrm{~S}$ & $D$ & 1,480 & 1,643 \\
\hline 1,533 & 50 & 27 & & 240 & $\mathrm{~S}$ & 16 & 3 & $\mathrm{~S}$ & D & 1,255 & 1,393 \\
\hline 1,534 & 50 & 27 & 0.9 & 240 & $S$ & 20 & 3 & $S$ & $D$ & 1,256 & 1,394 \\
\hline 1,535 & 50 & 27 & & 240 & $S$ & 24 & 3 & $S$ & $R$ & 2,206 & 1,403 \\
\hline 1,536 & 50 & 27 & & 480 & $\mathrm{~S}$ & 24 & 3 & S & $R$ & 2,272 & 1,445 \\
\hline 1,537 & 50 & 30 & & 240 & $S$ & 16 & 5 & 1 & $\mathrm{D}$ & 1,820 & 2,020 \\
\hline 1,538 & 50 & 30 & & 240 & S & 16 & 3 & I & $\mathrm{D}$ & 1,595 & 1,770 \\
\hline 1,539 & 50 & 30 & 0.9 & 240 & $\mathrm{~S}$ & 20 & 3 & 1 & $D$ & 1,596 & 1,772 \\
\hline 1,540 & 50 & 30 & & 240 & $S$ & 16 & 5 & $S$ & D & 1,500 & 1,665 \\
\hline 1,541 & 50 & 30 & & 240 & $S$ & 16 & 3 & $S$ & D & 1,275 & 1,415 \\
\hline 1,542 & 50 & 30 & 0.9 & 240 & $\mathrm{~s}$ & 20 & 3 & $\mathrm{~s}$ & D & 1,276 & 1,416 \\
\hline 1,543 & 50 & 36 & & 240 & $S$ & 16 & 5 & I & D & 1,867 & 2,072 \\
\hline 1,544 & 50 & 36 & & 240 & $S$ & 16 & 3 & I & $D$ & 1,642 & 1,823 \\
\hline 1,545 & 50 & 36 & 0.9 & 240 & $S$ & 20 & 3 & 1 & $D$ & 1,643 & 1,824 \\
\hline 1,546 & 50 & 36 & & 240 & $\mathrm{~S}$ & 24 & 3 & 1 & $\mathrm{R}$ & 2,929 & 1,863 \\
\hline 1,547 & 50 & 36 & & 480 & $S$ & 24 & 3 & 1 & $\mathrm{R}$ & 3,043 & 1,935 \\
\hline 1,548 & 50 & 36 & & 240 & $\mathrm{~S}$ & 16 & 5 & $S$ & D & 1,520 & 1,687 \\
\hline 1,549 & 50 & 36 & & 240 & $S$ & 16 & 3 & $\mathrm{~S}$ & D & 1,295 & 1,437 \\
\hline 1,550 & 50 & 36 & 0.9 & 240 & $\mathrm{~s}$ & 20 & 3 & $S$ & D & 1,296 & 1,439 \\
\hline 1,551 & 50 & 36 & & 240 & $S$ & 24 & 3 & $S$ & $\bar{R}$ & 2,238 & 1,423 \\
\hline 1,552 & 50 & 36 & & 480 & $\mathrm{~S}$ & 24 & 3 & $S$ & $R$ & 2,330 & 1,482 \\
\hline 1,553 & 50 & 41 & 0.9 & 240 & S & 20 & 3 & 1 & $\bar{D}$ & 2,020 & 2,242 \\
\hline 1,554 & 50 & 45 & & 240 & S & 16 & 5 & 1 & D & 2,235 & 2,481 \\
\hline 1,555 & 50 & 45 & & 240 & $S$ & 16 & 3 & 1 & D & 2,010 & 2,231 \\
\hline 1,556 & 50 & 45 & 0.9 & 240 & $S$ & 20 & 3 & 1 & D & 2,020 & 2,242 \\
\hline 1,557 & 50 & 54 & & 240 & $S$ & 16 & 5 & 1 & D & 2,308 & 2,562 \\
\hline 1,558 & 50 & 54 & & 240 & $\mathrm{~S}$ & 16 & 3 & 1 & D & 2,083 & 2,312 \\
\hline 1,559 & 50 & 54 & 0.9 & 240 & $S$ & 20 & 3 & 1 & $D$ & 2,092 & 2,322 \\
\hline 1,560 & 50 & 81 & & 240 & $\mathrm{~S}$ & 16 & 5 & 1 & D & 3,648 & 4,049 \\
\hline 1,561 & 50 & 81 & & 240 & $S$ & 16 & 3 & 1 & D & 3,423 & 3,800 \\
\hline 1,562 & 70 & 15 & & 240 & $A$ & 16 & 3 & I & D & 1,591 & 1,766 \\
\hline 1,563 & 70 & 18 & & 240 & A & 16 & 3 & 1 & $\bar{D}$ & 1,613 & 1,790 \\
\hline 1,564 & 70 & 24 & & 240 & $\mathrm{~A}$ & 16 & 3 & 1 & D & 2,069 & 2,297 \\
\hline 1,565 & 70 & 30 & & 240 & A & 16 & 3 & I & D & 2,182 & 2,422 \\
\hline 1,566 & 70 & 36 & & 240 & A & 16 & 3 & $T$ & $D$ & 2,244 & 2,491 \\
\hline 1,567 & 70 & 45 & & 240 & A & 16 & 3 & 1 & $D$ & 2,612 & 2,899 \\
\hline 1,568 & 70 & 54 & & 240 & A & 16 & 3 & 1 & D & 2,658 & 2,950 \\
\hline 1,569 & 80 & 14 & 0.7 & 240 & $S$ & 24 & 3 & 1 & D & 1,362 & 1,512 \\
\hline 1,570 & 80 & 14 & 0.8 & 240 & $S$ & 20 & 3 & 1 & D & 1,364 & 1,514 \\
\hline 1,571 & 80 & 14 & 0.7 & 240 & 5 & 24 & 3 & $\mathrm{~S}$ & $\mathrm{D}$ & 1,058 & 1,174 \\
\hline 1,572 & 80 & 14 & 0.8 & 240 & $\mathrm{~s}$ & 20 & 3 & $S$ & D & 1,060 & 1,177 \\
\hline 1,573 & 80 & 15 & & 240 & $\bar{A}$ & 16 & 3 & 1 & D & 1,756 & 1,949 \\
\hline 1,574 & 80 & 15 & 0.7 & 240 & $S$ & 24 & 3 & $T$ & D & 1,399 & 1,553 \\
\hline 1,575 & 80 & 15 & & 240 & $S$ & & 5 & 1 & $\mathrm{R}$ & 1,387 & 1,179 \\
\hline 1,576 & 80 & 15 & & 240 & $S$ & & 5 & 1 & R & 1,293 & 1,099 \\
\hline
\end{tabular}


Table A.3. Electric Storage Water Heaters (contd)

\begin{tabular}{|c|c|c|c|c|c|c|c|c|c|c|c|}
\hline REC & VOL & INP & STBY & VOLT & TANK & RVAL & WARR & THERM & CTYPE & LCOST & CCOST \\
\hline 1,577 & 80 & 15 & 0.7 & 240 & $S$ & 25 & 3 & 1 & D & 1,380 & 1,532 \\
\hline 1,578 & 80 & 15 & 0.8 & 240 & $S$ & 20 & 3 & 1 & D & 1,400 & 1,554 \\
\hline 1,579 & 80 & 15 & 0.7 & 240 & $S$ & 24 & 3 & $S$ & D & 1,058 & 1,174 \\
\hline 1,580 & 80 & 15 & & 240 & $\mathrm{~S}$ & & 5 & $\mathrm{~s}$ & $\bar{R}$ & 1,232 & 1,047 \\
\hline 1,581 & 80 & 15 & & 240 & $S$ & & 5 & $S$ & $\mathbf{R}$ & 1,138 & 967 \\
\hline 1,582 & 80 & 15 & 0.7 & 240 & $S$ & 25 & 3 & $S$ & $\mathrm{D}$ & 1,058 & 1,174 \\
\hline 1,583 & 80 & 15 & 0.8 & 240 & $S$ & 20 & 3 & $S$ & $\bar{D}$ & 1,060 & 1,177 \\
\hline 1,584 & 80 & 18 & & 240 & $A$ & 16 & 3 & $T$ & D & 1,767 & 1,961 \\
\hline 1,585 & 80 & 18 & 0.7 & 240 & $S$ & 24 & 3 & 1 & $D$ & 1,404 & 1,558 \\
\hline 1,586 & 80 & 18 & & 240 & $S$ & $\cdot$ & 5 & 1 & D & 1,123 & 1,348 \\
\hline 1,587 & 80 & 18 & 0.7 & 240 & $\mathrm{~S}$ & 25 & 3 & 1 & $\bar{D}$ & 1,390 & 1,543 \\
\hline 1,588 & 80 & 18 & 0.8 & 240 & $\mathrm{~S}$ & 20 & 3 & 1 & D & 1,405 & 1,560 \\
\hline 1,589 & 80 & 18 & 0.7 & 240 & $\mathbf{S}$ & 24 & 3 & $\mathrm{~S}$ & $\bar{D}$ & 1,074 & 1,192 \\
\hline 1,590 & 80 & 18 & 0.7 & 240 & s & 25 & 3 & $\mathrm{~S}$ & D & 1,073 & 1,191 \\
\hline 1,591 & 80 & 18 & 0.8 & 240 & $\bar{S}$ & 20 & 3 & $S$ & D & 1,073 & 1,191 \\
\hline 1,592 & 80 & 20 & & 240 & $S$ & & 5 & 1 & $R$ & 1,403 & 1,192 \\
\hline 1,593 & 80 & 20 & & 240 & $S$ & & 5 & 1 & $\mathrm{R}$ & 1,309 & 1,113 \\
\hline 1,594 & 80 & 24 & & 240 & A & 16 & 3 & 1 & D & 2,213 & 2,456 \\
\hline 1,595 & 80 & 24 & 0.7 & 240 & $S$ & 24 & 3 & 1 & $D$ & 1,757 & 1,950 \\
\hline 1,596 & 80 & 24 & & 240 & $S$ & & 5 & 1 & $R$ & 1,726 & 1,467 \\
\hline 1,597 & 80 & 24 & & 240 & $S$ & & 5 & 1 & $R$ & 1,632 & 1,387 \\
\hline 1,598 & 80 & 24 & & 240 & $S$ & & 5 & 1 & $D$ & 1,236 & 1,483 \\
\hline 1,599 & 80 & 24 & 0.7 & 240 & $s$ & 25 & 3 & $\mathrm{~T}$ & D & 1,745 & 1,937 \\
\hline 1,600 & 80 & 24 & 0.8 & 240 & $\mathrm{~s}$ & 20 & 3 & I & D & 1,762 & 1,956 \\
\hline 1,601 & 80 & 24 & 0.7 & 240 & $\mathrm{~S}$ & 24 & 3 & $S$ & D & 1,347 & 1,495 \\
\hline 1,602 & 80 & 24 & 0.7 & 240 & S & 25 & 3 & S & D & 1,350 & 1,499 \\
\hline 1,603 & 80 & 24 & 0.8 & 240 & $S$ & 20 & 3 & $\mathrm{~S}$ & D & 1,350 & 1,499 \\
\hline 1,604 & 80 & 27 & 0.7 & 240 & $S$ & 24 & 3 & 1 & D & 1,806 & 2,005 \\
\hline 1,605 & 80 & 27 & 0.7 & 240 & S & 25 & 3 & 1 & D & 1,800 & 1,998 \\
\hline 1,606 & 80 & 27 & 0.8 & 240 & $S$ & 20 & 3 & 1 & D & 1,815 & 2,015 \\
\hline 1,607 & 80 & 27 & 0.7 & 240 & $S$ & 24 & 3 & $S$ & D & 1,477 & 1,639 \\
\hline 1,608 & 80 & 27 & 0.7 & 240 & $S$ & 25 & 3 & $S$ & D & 1,476 & 1,638 \\
\hline 1,609 & 80 & 27 & 0.8 & 240 & $\mathrm{~S}$ & 20 & 3 & $S$ & D & 1,476 & 1,638 \\
\hline 1,610 & 80 & 30 & & 240 & $A$ & 16 & 3 & I & D & 2,324 & 2,580 \\
\hline 1,611 & 80 & 30 & 0.7 & 240 & $\mathrm{~S}$ & 24 & 3 & 1 & D & 1,844 & 2,047 \\
\hline 1,612 & 80 & 30 & & 240 & $\mathrm{~s}$ & & 5 & 1 & $\mathbf{R}$ & 1,792 & 1,523 \\
\hline 1,613 & 80 & 30 & & 240 & $S$ & & 5 & $T$ & $\mathbf{R}$ & 1,698 & 1,443 \\
\hline 1,614 & 80 & 30 & & 240 & $S$ & & 5 & 1 & D & 1,311 & 1,573 \\
\hline 1,615 & 80 & 30 & 0.7 & 240 & $S$ & 25 & 3 & $T$ & D & 1,835 & 2,037 \\
\hline 1,616 & 80 & 30 & 0.8 & 240 & $S$ & 20 & 3 & 1 & D & 1,845 & 2,048 \\
\hline 1,617 & 80 & 30 & 0.7 & 240 & s & 24 & 3 & $S$ & D & 1,485 & 1,648 \\
\hline 1,618 & 80 & 30 & 0.7 & 240 & $S$ & 25 & 3 & $\mathrm{~s}$ & D & 1,485 & 1,648 \\
\hline 1,619 & 80 & 30 & 0.8 & 240 & $\mathrm{~s}$ & 20 & 3 & $s$ & D & 1,487 & 1,651 \\
\hline 1,620 & 80 & 35 & & 240 & $\mathrm{~S}$ & & 5 & 1 & $R$ & 1,962 & 1,668 \\
\hline 1,621 & 80 & 35 & & 240 & $\mathrm{~s}$ & & 5 & 1 & $\mathbf{R}$ & 1,868 & 1,588 \\
\hline
\end{tabular}


Table A.3. Electric Storage Water Heaters (contd)

\begin{tabular}{|c|c|c|c|c|c|c|c|c|c|c|c|}
\hline REC & VOL & INP & STBY & VOLT & TANK & RVAL & WARR & THERM & CTYPE & LCOST & CCOST \\
\hline 1,622 & 80 & 36 & & 240 & A & 16 & 3 & 1 & D & 2,389 & 2,652 \\
\hline 1,623 & 80 & 36 & 0.7 & 240 & S & 24 & 3 & 1 & $D$ & 1,890 & 2,098 \\
\hline 1,624 & 80 & 36 & & 240 & $S$ & & 5 & 1 & $D$ & 1,432 & 1,718 \\
\hline 1,625 & 80 & 36 & 0.7 & 240 & $S$ & 25 & 3 & 1 & $\bar{D}$ & 1,881 & 2,088 \\
\hline 1,626 & 80 & 36 & 0.8 & 240 & S & 20 & 3 & 1 & D & 1,891 & 2,099 \\
\hline 1,627 & 80 & 36 & 0.7 & 240 & $S$ & 24 & 3 & $S$ & $\bar{D}$ & 1,496 & 1,661 \\
\hline 1,628 & 80 & 36 & 0.7 & 240 & 5 & 25 & 3 & S & D & 1,795 & 1,992 \\
\hline 1,629 & 80 & 36 & 0.8 & 240 & $S$ & 20 & 3 & S & $D$ & 1,496 & 1,661 \\
\hline 1,630 & 80 & 40 & & 240 & $S$ & & 5 & I & $\bar{R}$ & 1,971 & 1,675 \\
\hline 1,631 & 80 & 40 & & 240 & $S$ & & 5 & 1 & $\mathrm{R}$ & 1,877 & 1,595 \\
\hline 1,632 & 80 & 41 & 0.8 & 240 & $S$ & 20 & 3 & I & D & 2,254 & 2,502 \\
\hline 1,633 & 80 & 41 & 0.8 & 240 & $S$ & 20 & 3 & $S$ & $\bar{D}$ & 1,879 & 2,086 \\
\hline 1,634 & 80 & 45 & & 240 & $A$ & 16 & 3 & 1 & D & 2,761 & 3,065 \\
\hline 1,635 & 80 & 45 & 0.7 & 240 & $S$ & 24 & 3 & I & D & 2,252 & 2,500 \\
\hline 1,636 & 80 & 45 & & 240 & $S$ & & 5 & I & $R$ & 2,619 & 2,226 \\
\hline 1,637 & 80 & 45 & & 240 & $S$ & & 5 & I & $\bar{R}$ & 2,525 & 2,146 \\
\hline 1,638 & 80 & 45 & 0.7 & 240 & $S$ & 25 & 3 & 1 & D & 2,244 & 2,491 \\
\hline 1,639 & 80 & 45 & 0.8 & 240 & $S$ & 20 & 3 & 1 & D & 2,254 & 2,502 \\
\hline 1,640 & 80 & 45 & 0.7 & 240 & $S$ & 24 & 3 & S & D & 1,877 & 2,083 \\
\hline 1,641 & 80 & 45 & 0.7 & 240 & S. & 25 & 3 & $S$ & D & 1,877 & 2,083 \\
\hline 1,642 & 80 & 45 & 0.8 & 240 & $S$ & 20 & 3 & $S$ & D & 1,879 & 2,086 \\
\hline 1,643 & 80 & 48 & & 240 & $S$ & & 5 & $T$ & $\bar{D}$ & 1,455 & 1,746 \\
\hline 1,644 & 80 & 52 & & 240 & $S$ & & 5 & 1 & D & 1,501 & 1,801 \\
\hline 1,645 & 80 & 54 & & 240 & A & 16 & 3 & 1 & D & 2,797 & 3,105 \\
\hline 1,646 & 80 & 54 & 0.7 & 240 & $S$ & 24 & 3 & 1 & D & 2,322 & 2,577 \\
\hline 1,647 & 80 & 54 & 0.7 & 240 & $S$ & 25 & 3 & 1 & D & 2,314 & 2,569 \\
\hline 1,648 & 80 & 54 & 0.8 & 240 & $\mathrm{~S}$ & 20 & 3 & I & $\mathbf{R}$ & 2,324 & 2,580 \\
\hline 1,649 & 80 & 54 & 0.7 & 240 & $S$ & 24 & 3 & $S$ & $D$ & 1,890 & 2,098 \\
\hline 1,650 & 80 & 54 & 0.7 & 240 & $S$ & 25 & 3 & $S$ & D & 1,889 & 2,097 \\
\hline 1,651 & 80 & 54 & 0.8 & 240 & $S$ & 20 & 3 & $S$ & $\mathrm{R}$ & 1,889 & 2,097 \\
\hline 1,652 & 80 & 14 & & 240 & $S$ & 16 & 5 & 1 & $D$ & 1,587 & 1,762 \\
\hline 1,653 & 80 & 14 & & 240 & $\mathrm{~S}$ & 16 & 3 & 1 & D & 1,362 & 1,512 \\
\hline 1,654 & 80 & 14 & & 240 & $S$ & 16 & 5 & S & $\mathrm{D}$ & 1,283 & 1,424 \\
\hline 1,655 & 80 & 14 & & 240 & $\mathrm{~S}$ & 16 & 3 & $S$ & D & 1,058 & 1,174 \\
\hline 1,656 & 80 & 15 & & 240 & $S$ & 16 & 5 & 1 & D & 1,624 & 1,803 \\
\hline 1,657 & 80 & 15 & & 240 & 5 & 16 & 3 & 1 & D & 1,399 & 1,553 \\
\hline 1,658 & 80 & 15 & & 240 & $S$ & 16 & 5 & $S$ & D & 1,283 & 1,424 \\
\hline 1,659 & 80 & 15 & & 240 & $S$ & 16 & 3 & $S$ & D & 1,058 & 1,174 \\
\hline 1,660 & 80 & 18 & & 240 & $S$ & 16 & 5 & 1 & D & 1,629 & 1,808 \\
\hline 1,661 & 80 & 18 & & 240 & $S$ & 16 & 3 & 1 & $D$ & 1,404 & 1,558 \\
\hline 1,662 & 80 & 18 & & 240 & $S$ & 24 & 3 & 1 & $R$ & 2,452 & 1,559 \\
\hline 1,663 & 80 & 18 & & 480 & $S$ & 24 & 3 & 1 & $R$ & 2,530 & 1,609 \\
\hline 1,664 & 80 & 18 & & 240 & $\mathrm{~S}$ & 16 & 5 & $S$ & $D$ & 1,299 & 1,442 \\
\hline 1,665 & 80 & 18 & & 240 & $S$ & 16 & 3 & s & D & 1,074 & 1,192 \\
\hline 1,666 & 80 & 18 & & 240 & $S$ & 24 & 3 & $S$ & $\mathrm{R}$ & 1,840 & 1,170 \\
\hline
\end{tabular}


Table A.3. Electric Storage Water Heaters (contd)

\begin{tabular}{|c|c|c|c|c|c|c|c|c|c|c|c|}
\hline REC & VOL & INP & STBY & VOLT & TANK & RVAL & WARR & THERM & CTYPE & LCOST & CcosT \\
\hline 1,667 & 80 & 18 & & 480 & $\mathrm{~S}$ & 24 & 3 & $S$ & $\mathbf{R}$ & 1,949 & 1,240 \\
\hline 1,668 & 80 & 27 & & 240 & $\mathrm{~S}$ & 16 & 5 & $\mathrm{I}$ & $\bar{D}$ & 2,031 & 2,254 \\
\hline 1,669 & 80 & 27 & & 240 & $S$ & 16 & 3 & I & D & 1,806 & 2,005 \\
\hline 1,670 & 80 & 27 & & 240 & $S$ & 24 & 3 & 1 & $R$ & 3,232 & 2,056 \\
\hline 1,671 & 80 & 27 & & 480 & $S$ & 24 & 3 & I & $\mathbf{R}$ & 3,310 & 2,105 \\
\hline 1,672 & 80 & 27 & & 240 & S & 16 & 5 & $S$ & D & 1,702 & 1,889 \\
\hline 1,673 & 80 & 27 & & 240 & $S$ & 16 & 3 & $S$ & D & 1,477 & 1,639 \\
\hline 1,674 & 80 & 27 & & 240 & $S$ & 24 & 3 & $\mathrm{~S}$ & $\mathbf{R}$ & 2,651 & 1,686 \\
\hline 1.675 & 80 & 27 & & 480 & $S$ & 24 & 3 & $S$ & $\mathbf{R}$ & 2,734 & 1,739 \\
\hline 1,676 & 80 & 30 & & 240 & $S$ & 16 & 5 & 1 & D & 2,069 & 2,297 \\
\hline 1,677 & 80 & 30 & & 240 & $\mathrm{~S}$ & 16 & 3 & 1 & $\bar{D}$ & 1,844 & 2,047 \\
\hline 1,678 & 80 & 30 & & 240 & $S$ & 16 & 5 & S & $\mathrm{D}$ & 1,710 & 1,898 \\
\hline 1,679 & 80 & 30 & & 240 & $S$ & 16 & 3 & $\mathrm{~S}$ & $\bar{D}$ & 1,485 & 1,648 \\
\hline 1,680 & 80 & 36 & & 240 & $S$ & 16 & 5 & $T$ & $\bar{D}$ & 2,115 & 2,348 \\
\hline 1,681 & 80 & 36 & & 240 & S & 16 & 3 & 1 & $D$ & 1,890 & 2,098 \\
\hline 1,682 & 80 & 36 & & 240 & $\mathrm{~S}$ & 24 & 3 & $T$ & $\bar{R}$ & 3,408 & 2,167 \\
\hline 1,683 & 80 & 36 & & 480 & S & 24 & 3 & 1 & $\mathrm{R}$ & 3,495 & 2,223 \\
\hline 1,684 & 80 & 36 & & 240 & S & 16 & 5 & $\mathrm{~S}$ & D & 1,721 & 1,910 \\
\hline 1,685 & 80 & 36 & & 240 & S & 16 & 3 & $\mathrm{~S}$ & $\bar{D}$ & 1,496 & 1,661 \\
\hline 1,686 & 80 & 36 & & 240 & $S$ & 24 & 3 & $S$ & $R$ & 2,708 & 1,722 \\
\hline 1687 & 80 & 36 & & 480 & $S$ & 24 & 3 & $S$ & $\mathrm{R}$ & 2.785 & 1771 \\
\hline 1,688 & 80 & 45 & & 240 & S & 16 & 5 & 1 & D & 2,477 & 2,749 \\
\hline 1,689 & 80 & 45 & & 240 & $S$ & 16 & 3 & 1 & D & 2,256 & 2,504 \\
\hline 1,690 & 80 & 45 & & 240 & $\mathrm{~s}$ & 24 & 3 & 1 & $R$ & 3,832 & 2,437 \\
\hline 1,691 & 80 & 45 & & 480 & $\mathrm{~S}$ & 24 & 3 & 1 & $R$ & 3,939 & 2,505 \\
\hline 1,692 & 80 & 45 & & 240 & S & 16 & 5 & S & D & 2,102 & 2,333 \\
\hline 1,693 & 80 & 45 & & 240 & S & 16 & 3 & $S$ & D & 1,877 & 2,083 \\
\hline 1,694 & 80 & 45 & & 240 & $\mathrm{~S}$ & 24 & 3 & $\mathrm{~S}$ & $R$ & 3,283 & 2,088 \\
\hline 1,695 & 80 & 45 & & 480 & $S$ & 24 & 3 & $\mathrm{~S}$ & $\mathrm{R}$ & 3,396 & 2,160 \\
\hline 1,696 & 80 & 54 & & 240 & S & 16 & 5 & 1 & $D$ & 2,547 & 2,827 \\
\hline 1,697 & 80 & 54 & & 240 & $\mathrm{~S}$ & 16 & 3 & 1 & $\bar{D}$ & 2,322 & 2,577 \\
\hline 1.698 & 80 & 54 & & 240 & $S$ & 24 & 3 & $T$ & $\mathrm{R}$ & 3,721 & 2,367 \\
\hline 1,699 & 80 & 54 & & 480 & $\mathrm{~S}$ & 24 & 3 & 1 & $R$ & 3,792 & 2,412 \\
\hline 1,700 & 80 & 54 & & 240 & S & 16 & 5 & S & D & 2.115 & 2,348 \\
\hline 1,701 & 80 & 54 & & 240 & $\mathbf{S}$ & 16 & 3 & $S$ & $D$ & 1,890 & 2,098 \\
\hline 1,702 & 80 & 54 & & 240 & $S$ & 24 & 3 & $\mathrm{~S}$ & $R$ & 3,333 & 2,120 \\
\hline 1,703 & 80 & 54 & & 480 & $\mathrm{~S}$ & 24 & 3 & S & $\mathrm{R}$ & 3,439 & 2,187 \\
\hline 1,704 & 80 & 81 & & 240 & $\mathbf{S}$ & 16 & 5 & 1 & $D$ & 3,888 & 4,316 \\
\hline 1,705 & 80 & 81 & & 240 & $\mathrm{~S}$ & 16 & 3 & 1 & D & 3,663 & 4,066 \\
\hline 1,706 & 90 & 15 & 0.6 & 240 & A & 24 & 3 & 1 & $D$ & 1,721 & 1,910 \\
\hline 1,707 & 90 & 15 & 0.6 & 240 & $\bar{A}$ & 24 & 3 & $S$ & D & 1,405 & 1,560 \\
\hline 1,708 & 90 & 15 & 0.6 & 240 & $\mathrm{~S}$ & 24 & 3 & 1 & $D$ & 1,380 & 1,532 \\
\hline 1,709 & 90 & 15 & 0.6 & 240 & s & 24 & 3 & $\mathrm{~s}$ & D & 1,064 & 1,181 \\
\hline 1,710 & 90 & 18 & 0.6 & 240 & A & 24 & 3 & 1 & D & 1,731 & 1.921 \\
\hline 1,711 & 90 & 18 & 0.6 & 240 & $A$ & 24 & 3 & $S$ & $\bar{D}$ & 1,422 & 1.578 \\
\hline
\end{tabular}


Table A.3. Electric Storage Water Heaters (contd)

\begin{tabular}{|c|c|c|c|c|c|c|c|c|c|c|c|}
\hline REC & VOL & INP & STBY & VOLT & TANK & RVAL & WARR & THERM & CTYPE & LCOST & CCOST \\
\hline 1,712 & 90 & 18 & 0.6 & 240 & $\mathrm{~S}$ & 24 & 3 & 1 & D & 1,390 & 1,543 \\
\hline 1,713 & 90 & 18 & 0.6 & 240 & $S$ & 24 & 3 & $S$ & D & 1,081 & 1,199 \\
\hline 1,714 & 90 & 24 & 0.6 & 240 & $\bar{A}$ & 24 & 3 & 1 & $\bar{D}$ & 2,086 & 2,315 \\
\hline 1,715 & 90 & 24 & 0.6 & 240 & $A$ & 24 & 3 & $S$ & D & 1,700 & 1,887 \\
\hline 1,716 & 90 & 24 & 0.6 & 240 & $S$ & 24 & 3 & 1 & D & 1,745 & 1,937 \\
\hline 1,717 & 90 & 24 & 0.6 & 240 & $S$ & 24 & 3 & $S$ & D & 1,359 & 1,508 \\
\hline 1,718 & 90 & 27 & 0.6 & 240 & $\bar{A}$ & 24 & 3 & $T$ & $D$ & 2,141 & 2,377 \\
\hline 1,719 & 90 & 27 & 0.6 & 240 & $A$ & 24 & 3 & $S$ & $D$ & 1,817 & 2,017 \\
\hline 1,720 & 90 & 27 & 0.6 & 240 & $S$ & 24 & 3 & 1 & D & 1,800 & 1,998 \\
\hline 1,721 & 90 & 27 & 0.6 & 240 & $S$ & 24 & 3 & $S$ & D & 1,476 & 1,638 \\
\hline 1,722 & 90 & 30 & 0.6 & 240 & $\mathrm{~A}$ & 24 & 3 & 1 & $\bar{D}$ & 2,176 & 2,415 \\
\hline 1,723 & 90 & 30 & 0.6 & 240 & $\bar{A}$ & 24 & 3 & $S$ & D & 1,826 & 2,027 \\
\hline 1,724 & 90 & 30 & 0.6 & 240 & $S$ & 24 & 3 & 1 & D & 1,835 & 2,037 \\
\hline 1,725 & 90 & 30 & 0.6 & 240 & $S$ & 24 & 3 & $S$ & D & 1,485 & 1,648 \\
\hline 1,726 & 90 & 36 & 0.6 & 240 & A & 24 & 3 & I & $D$ & 2,222 & 2,466 \\
\hline 1,727 & 90 & 36 & 0.6 & 240 & $\bar{A}$ & 24 & 3 & $S$ & $\bar{D}$ & 1,835 & 2,037 \\
\hline 1,728 & 90 & 36 & 0.6 & 240 & $S$ & 24 & 3 & 1 & D & 1,881 & 2,088 \\
\hline 1,729 & 90 & 36 & 0.6 & 240 & S & 24 & 3 & $\mathrm{~S}$ & D & 1,494 & 1,659 \\
\hline 1,730 & 90 & 45 & 0.6 & 240 & A & 24 & 3 & 1 & D & 2,585 & 2,869 \\
\hline 1,731 & 90 & 45 & 0.6 & 240 & $\bar{A}$ & 24 & 3 & $S$ & D & 2,221 & 2,465 \\
\hline 1,732 & 90 & 45 & 0.6 & 240 & $S$ & 24 & 3 & 1 & D & 2,244 & 2,491 \\
\hline 1,733 & 90 & 45 & 0.6 & 240 & $S$ & 24 & 3 & $S$ & $\bar{D}$ & 1,880 & 2,087 \\
\hline 1,734 & 90 & 54 & 0.6 & 240 & A & 24 & 3 & 1 & D & 2,655 & 2,947 \\
\hline 1,735 & 90 & 54 & 0.6 & 240 & A & 24 & 3 & $S$ & D & 2,231 & 2,476 \\
\hline 1,736 & 90 & 54 & 0.6 & 240 & $S$ & 24 & 3 & 1 & $D$ & 2,314 & 2,569 \\
\hline 1,737 & 90 & 54 & 0.6 & 240 & $S$ & 24 & 3 & $S$ & D & 1,890 & 2,098 \\
\hline 1,738 & 100 & 15 & 0.6 & 240 & $\bar{A}$ & 16 & 3 & 1 & D & 1,932 & 2,145 \\
\hline 1,739 & 100 & 18 & 0.6 & 240 & A & 16 & 3 & 1 & D & 1,976 & 2,193 \\
\hline 1,740 & 100 & 18 & & 240 & $S$ & & 5 & 1 & D & 1,123 & 1,348 \\
\hline 1,741 & 100 & 24 & 0.6 & 240 & A & 16 & 3 & $T$ & D & 2,315 & 2,570 \\
\hline 1,742 & 100 & 24 & & 240 & $S$ & & 5 & 1 & D & 1,236 & 1,483 \\
\hline 1,743 & 100 & 30 & 0.6 & 240 & A & 16 & 3 & 1 & $D$ & 2,433 & 2,701 \\
\hline 1,744 & 100 & 30 & & 240 & S & & 5 & 1 & D & 1,311 & 1,573 \\
\hline 1,745 & 100 & 36 & 0.6 & 240 & A & 16 & 3 & 1 & D & 2,489 & 2,763 \\
\hline 1,746 & 100 & 36 & & 240 & $S$ & & 5 & 1 & $D$ & 1,432 & 1,718 \\
\hline 1,747 & 100 & 45 & 0.6 & 240 & $A$ & 16 & 3 & 1 & $D$ & 2,872 & 3,188 \\
\hline 1,748 & 100 & 48 & & 240 & $S$ & & 5 & 1 & D & 1,455 & 1,746 \\
\hline 1,749 & 100 & 52 & & 240 & $S$ & & 5 & 1 & D & 1,501 & 1,801 \\
\hline 1,750 & 100 & 54 & 0.6 & 240 & $\bar{A}$ & 16 & 3 & 1 & D & 2,912 & 3,232 \\
\hline 1,751 & 120 & 20 & & 240 & $S$ & & 5 & $T$ & $R$ & 1,608 & 1,367 \\
\hline 1,752 & 120 & 20 & & 240 & $S$ & & 5 & 1 & $R$ & 1,470 & 1,250 \\
\hline 1,753 & 120 & 24 & & 240 & $\mathrm{~S}$ & & 5 & 1 & $\mathbf{R}$ & 1,931 & 1,642 \\
\hline 1,754 & 120 & 24 & & 240 & $S$ & & 5 & $I$ & $\mathrm{R}$ & 1,793 & 1,524 \\
\hline 1,755 & 120 & 30 & & 240 & $S$ & & 5 & 1 & $R$ & 1,997 & 1,698 \\
\hline 1,756 & 120 & 30 & & 240 & $S$ & & 5 & 1 & $R$ & 1,859 & 1,580 \\
\hline
\end{tabular}


Table A.3. Electric Storage Water Heaters (contd)

\begin{tabular}{|c|c|c|c|c|c|c|c|c|c|c|c|}
\hline REC & VOL & INP & STBY & VOLT & TANK & RVAL & WARR & THERM & CTYPE & LCOST & Ccost \\
\hline 1,757 & 120 & 35 & & 240 & $S$ & & 5 & 1 & $\mathbf{R}$ & 2,167 & 1,842 \\
\hline 1,758 & 120 & 35 & & 240 & $S$ & & 5 & 1 & $R$ & 2,029 & 1,725 \\
\hline 1,759 & 120 & 40 & & 240 & $S$ & & 5 & 1 & $\bar{R}$ & 2,023 & 1,719 \\
\hline 1,760 & 120 & 40 & & 240 & $S$ & & 5 & 1 & $R$ & 2,038 & 1,732 \\
\hline 1,761 & 120 & 45 & & 240 & $\mathrm{~S}$ & & 5 & 1 & $\mathrm{R}$ & 2,824 & 2,401 \\
\hline 1,762 & 120 & 45 & & 240 & $\mathrm{~S}$ & & 5 & $T$ & $\mathbf{R}$ & 2,686 & 2,283 \\
\hline 1,763 & 120 & 54 & & 240 & $S$ & & 5 & $T$ & $R$ & 2,843 & 2,417 \\
\hline 1,764 & 120 & 54 & & 240 & $\mathrm{~S}$ & & 5 & I & $\mathbf{R}$ & 2,705 & 2,299 \\
\hline 1,765 & 120 & 15 & 0.4 & 240 & $A$ & 25 & 3 & 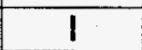 & D & 1,969 & 2,186 \\
\hline 1,766 & 120 & 15 & 0.4 & 240 & $\bar{A}$ & 25 & 3 & $S$ & D & 1,529 & 1,697 \\
\hline 1,767 & 120 & 15 & 0.4 & 240 & $\mathrm{~S}$ & 25 & 3 & $\mathrm{~T}$ & D & 1,665 & 1,848 \\
\hline 1,768 & 120 & 15 & 0.4 & 240 & S & 25 & 3 & $S$ & D & 1,229 & 1,364 \\
\hline 1,769 & 120 & 18 & 0.4 & 240 & $\bar{A}$ & 25 & 3 & 1 & D & 1,997 & 2,217 \\
\hline 1,770 & 120 & 18 & 0.4 & 240 & A & 25 & 3 & $\bar{S}$ & $\bar{D}$ & 1,546 & 1,716 \\
\hline 1,771 & 120 & 18 & 0.4 & 240 & $S$ & 25 & 3 & 1 & D & 1,695 & 1,881 \\
\hline 1,772 & 120 & 18 & 0.4 & 240 & $S$ & 25 & 3 & $S$ & $D$ & 1,246 & 1,383 \\
\hline 1,773 & 120 & 20 & & 208 & $S$ & 17 & 3 & $S$ & D & 1,230 & 1,365 \\
\hline 1,774 & 120 & 24 & 0.4 & 240 & A & 25 & 3 & 1 & D & 2,130 & 2,364 \\
\hline 1,775 & 120 & 24 & 0.4 & 240 & $\bar{A}$ & 25 & 3 & $S$ & D & 1,896 & 2,105 \\
\hline 1,776 & 120 & 24 & 0.4 & 240 & $S$ & 25 & 3 & 1 & D & 1,880 & 2,087 \\
\hline 1,777 & 120 & 24 & & 240 & S & 17 & 3 & $S$ & D & 1,230 & 1,365 \\
\hline 1,778 & 120 & 24 & 0.4 & 240 & $S$ & 25 & 3 & $S$ & D & 1,601 & 1,777 \\
\hline 1,779 & 120 & 27 & 0.4 & 240 & A & 25 & 3 & $\mathrm{I}$ & D & 2,263 & 2,512 \\
\hline 1,780 & 120 & 27 & 0.4 & 240 & A & 25 & 3 & 5 & D & 1,910 & 2,120 \\
\hline 1,781 & 120 & 27 & 0.4 & 240 & $S$ & 25 & 3 & 1 & D & 1,960 & 2,176 \\
\hline 1,782 & 120 & 27 & 0.4 & 240 & $S$ & 25 & 3 & S & D & 1,609 & 1,786 \\
\hline 1,783 & 120 & 30 & 0.4 & 240 & A & 25 & 3 & 1 & D & 2,308 & 2,562 \\
\hline 1,784 & 120 & 30 & 0.4 & 240 & $A$ & 25 & 3 & $S$ & $D$ & 1,922 & 2,133 \\
\hline 1,785 & 120 & 30 & 0.4 & 240 & $S$ & 25 & 3 & 1 & D & 2,000 & 2,220 \\
\hline 1,786 & 120 & 30 & & 208 & S & 17 & 3 & $S$ & D & 1,520 & 1,687 \\
\hline 1,787 & 120 & 30 & & 208 & $S$ & 17 & 3 & $S$ & D & 1,600 & 1,776 \\
\hline 1,788 & 120 & 30 & 0.4 & 240 & $S$ & 25 & 3 & $S$ & D & 1,620 & 1,798 \\
\hline 1,789 & 120 & 36 & 0.4 & 240 & $A$ & 25 & 3 & 1 & D & 2,344 & 2,602 \\
\hline 1,790 & 120 & 36 & 0.4 & 240 & $\bar{A}$ & 25 & 3 & $S$ & D & 1,932 & 2,145 \\
\hline 1,791 & 120 & 36 & 0.4 & 240 & $S$ & 25 & 3 & 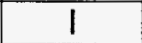 & D & 2,039 & 2,263 \\
\hline 1,792 & 120 & 36 & & 240 & $S$ & 17 & 3 & $S$ & D & 1,520 & 1,687 \\
\hline 1,793 & 120 & 36 & & 240 & $S$ & 17 & 3 & $S$ & D & 1,600 & 1,776 \\
\hline 1,794 & 120 & 36 & & 480 & $S$ & 17 & 3 & $S$ & D & 1,620 & 1,798 \\
\hline 1,795 & 120 & 36 & 0.4 & 240 & $S$ & 25 & 3 & $S$ & $D$ & 1,629 & 1,808 \\
\hline 1,796 & 120 & 45 & 0.4 & 240 & $A$ & 25 & 3 & 1 & D & 2,754 & 3,057 \\
\hline 1,797 & 120 & 45 & 0.4 & 240 & A & 25 & 3 & $S$ & D & 2,383 & 2,645 \\
\hline 1,798 & 120 & 45 & 0.4 & 240 & $S$ & 25 & 3 & 1 & D & 2,450 & 2,720 \\
\hline 1,799 & 120 & 45 & & 208 & $S$ & 17 & 3 & $S$ & D & 1,700 & 1,887 \\
\hline 1,800 & 120 & 45 & & 208 & $S$ & 17 & 3 & $S$ & D & 1,950 & 2,165 \\
\hline 1,801 & 120 & 45 & 0.4 & 240 & $S$ & 25 & 3 & $S$ & D & 2,083 & 2,312 \\
\hline
\end{tabular}


Table A.3. Electric Storage Water Heaters (contd)

\begin{tabular}{|c|c|c|c|c|c|c|c|c|c|c|c|}
\hline REC & VOL & INP & STBY & VOLT & TANK & RVAL & WARR & THERM & CTYPE & LCOST & CCOST \\
\hline 1,802 & 120 & 54 & 0.4 & 240 & A & 25 & 3 & 1 & D & 2,820 & 3,130 \\
\hline 1,803 & 120 & 54 & 0.4 & 240 & A & 25 & 3 & $S$ & D & 2,399 & 2,663 \\
\hline 1,804 & 120 & 54 & 0.4 & 240 & $S$ & 25 & 3 & $T$ & $\bar{D}$ & 2,520 & 2,797 \\
\hline 1,805 & $120^{\circ}$ & 54 & & 240 & $S$ & 17 & 3 & $S$ & D & 1,700 & 1,887 \\
\hline 1,806 & 120 & 54 & & 240 & $S$ & 17 & 3 & $S$ & $\bar{D}$ & 1,950 & 2,165 \\
\hline 1,807 & 120 & 54 & & 480 & $S$ & 17 & 3 & $S$ & D & 2,090 & 2,320 \\
\hline 1,808 & 120 & 54 & 0.4 & 240 & $S$ & 25 & 3 & $\mathrm{~S}$ & D & 2,099 & 2,330 \\
\hline 1,809 & 120 & 14 & 0.4 & 240 & $A$ & 24 & 3 & 1 & $D$ & 1,923 & 2,135 \\
\hline 1,810 & 120 & 14 & 0.4 & 240 & A & 24 & 3 & S & D & 1,529 & 1,697 \\
\hline 1,811 & 120 & 14 & & 240 & $\mathrm{~S}$ & 16 & 5 & 1 & D & 1,848 & 2,051 \\
\hline 1,812 & 120 & 14 & & 240 & $S$ & 16 & 3 & $T$ & $\bar{D}$ & 1,623 & 1,802 \\
\hline 1,813 & 120 & 14 & 0.4 & 240 & $S$ & 24 & 3 & 1 & $D$ & 1,623 & 1,802 \\
\hline 1,814 & 120 & 14 & 0.6 & 240 & $\bar{S}$ & 20 & 3 & 1 & $\bar{D}$ & 1,624 & 1,803 \\
\hline 1,815 & 120 & 14 & & 240 & $S$ & 16 & 5 & $\mathrm{~S}$ & D & 1,454 & 1,614 \\
\hline 1,816 & 120 & 14 & & 240 & $S$ & 16 & 3 & $S$ & $\bar{D}$ & 1,229 & 1,364 \\
\hline 1,817 & 120 & 14 & 0.4 & 240 & S & 24 & 3 & $S$ & D & 1,229 & 1,364 \\
\hline 1,818 & 120 & 14 & 0.6 & 240 & $S$ & 20 & 3 & $S$ & $D$ & 1,237 & 1,373 \\
\hline 1,819 & 120 & 15 & 0.4 & 240 & A & 24 & 3 & 1 & $\bar{D}$ & 2,059 & 2,285 \\
\hline 1,820 & 120 & 15 & 0.4 & 240 & $\bar{A}$ & 24 & 3 & 1 & D & 1,969 & 2,186 \\
\hline 1,821 & 120 & 15 & 0.6 & 240 & A & 16 & 3 & 1 & D & 2,124 & 2,358 \\
\hline 1,822 & 120 & 15 & 0.4 & 240 & $\bar{A}$ & 24 & 3 & S & D & 1,628 & 1,807 \\
\hline 1,823 & 120 & 15 & 0.4 & 240 & A & 24 & 3 & $S$ & D & 1,529 & 1,697 \\
\hline 1,824 & 120 & 15 & & 240 & $S$ & 16 & 5 & 1 & D & 1,894 & 2,102 \\
\hline 1,825 & 120 & 15 & & 240 & $S$ & 16 & 3 & 1 & D & 1,669 & 1,853 \\
\hline 1,826 & 120 & 15 & 0.4 & 240 & S & 24 & 3 & 1 & $D$ & 1,665 & 1,848 \\
\hline 1,827 & 120 & 15 & 0.4 & 240 & $S$ & 24 & 3 & 1 & D & 1,669 & 1,853 \\
\hline 1,828 & 120 & 15 & 0.6 & 240 & $S$ & 20 & 3 & $I$ & D & 1,670 & 1,854 \\
\hline 1,829 & 120 & 15 & & 240 & $S$ & 16 & 5 & $S$ & D & 1,454 & 1,614 \\
\hline 1,830 & 120 & 15 & & 240 & $S$ & 16 & 3 & $S$ & D & 1,229 & 1,364 \\
\hline 1,831 & 120 & 15 & 0.4 & 240 & $S$ & 24 & 3 & $S$ & D & 1,234 & 1,370 \\
\hline 1,832 & 120 & 15 & 0.4 & 240 & $S$ & 24 & 3 & $S$ & D & 1,229 & 1,364 \\
\hline 1,833 & 120 & 15 & 0.6 & 240 & $S$ & 20 & 3 & s & D & 1,230 & 1,365 \\
\hline 1,834 & 120 & 18 & 0.4 & 240 & $\bar{A}$ & 24 & 3 & 1 & D & 2,089 & 2,319 \\
\hline 1,835 & 120 & 18 & 0.4 & 240 & A & 24 & 3 & 1 & D & 1,997 & 2,217 \\
\hline 1,836 & 120 & 18 & & 240 & A & 24 & 3 & I & $\mathbf{R}$ & 3,867 & 2,459 \\
\hline 1,837 & 120 & 18 & & 480 & A & 24 & 3 & I & $\mathbf{R}$ & 3,924 & 2,496 \\
\hline 1,838 & 120 & 18 & 0.6 & 240 & A & 16 & 3 & $T$ & D & 2,185 & 2,425 \\
\hline 1,839 & 120 & 18 & 0.4 & 240 & $A$ & 24 & 3 & $S$ & D & 1,644 & 1,824 \\
\hline 1,840 & 120 & 18 & 0.4 & 240 & $A$ & 24 & 3 & $S$ & D & 1,546 & 1,716 \\
\hline 1,841 & 120 & 18 & & 240 & A & 24 & 3 & $S$ & $\mathrm{R}$ & 6,048 & 3,847 \\
\hline 1,842 & 120 & 18 & & 480 & A & 24 & 3 & $S$ & $\mathrm{R}$ & 3,171 & 2,017 \\
\hline 1,843 & 120 & 18 & & 240 & $S$ & 16 & 5 & 1 & D & 1,922 & 2,133 \\
\hline 1,844 & 120 & 18 & & 240 & $S$ & 16 & 3 & 1 & D & 1,697 & 1,884 \\
\hline 1,845 & 120 & 18 & 0.4 & 240 & $S$ & 24 & 3 & 1 & $D$ & 1,695 & 1,881 \\
\hline 1,846 & 120 & 18 & 0.4 & 240 & $S$ & 24 & 3 & 1 & D & 1,697 & 1,884 \\
\hline
\end{tabular}


Table A.3. Electric Storage Water Heaters (contd)

\begin{tabular}{|c|c|c|c|c|c|c|c|c|c|c|c|}
\hline REC & VOL & INP & STBY & VOLT & TANK & RVAL & WARR & THERM & CTYPE & LCOST & CCOST \\
\hline 1,847 & 120 & 18 & & 240 & $\mathrm{~S}$ & & 5 & 1 & $\mathrm{D}$ & 1,123 & 1,348 \\
\hline 1,848 & 120 & 18 & 0.6 & 240 & $\mathrm{~s}$ & 20 & 3 & 1 & D & 1,699 & 1,886 \\
\hline 1,849 & 120 & 18 & & 240 & $S$ & 24 & 3 & 1 & $\mathbf{R}$ & 3,017 & 1,919 \\
\hline 1,850 & 120 & 18 & & 480 & $S$ & 24 & 3 & 1 & $\bar{R}$ & 3,074 & 1,955 \\
\hline 1,851 & 120 & 18 & & 240 & $S$ & 16 & 5 & $\bar{S}$ & $D$ & 1,471 & 1,633 \\
\hline 1,852 & 120 & 18 & & 240 & S & 16 & 3 & S & D & 1,246 & 1,383 \\
\hline 1,853 & 120 & 18 & 0.4 & 240 & $S$ & 24 & 3 & $S$ & $\bar{D}$ & 1,250 & 1,387 \\
\hline 1,854 & 120 & 18 & 0.4 & 240 & $\mathrm{~s}$ & 24 & 3 & $\mathrm{~S}$ & D & 1,246 & 1,383 \\
\hline 1,855 & 120 & 18 & 0.6 & 240 & $S$ & 20 & 3 & $\bar{S}$ & $\bar{D}$ & 1,246 & 1,383 \\
\hline 1,856 & 120 & 18 & & 240 & $S$ & 24 & 3 & $S$ & $\mathrm{R}$ & 2,198 & 1,398 \\
\hline 1,857 & 120 & 18 & & 480 & $S$ & 24 & 3 & 5 & $\mathbf{R}$ & 2,321 & 1,476 \\
\hline 1,858 & 120 & 24 & 0.4 & 240 & A & 24 & 3 & 1 & D & 2,274 & 2,524 \\
\hline 1,859 & 120 & 24 & 0.4 & 240 & $\bar{A}$ & 24 & 3 & 1 & D & 2,183 & 2,423 \\
\hline 1,860 & 120 & 24 & 0.6 & 240 & A & 16 & 3 & I & D & 2,417 & 2,683 \\
\hline 1,861 & 120 & 24 & 0.4 & 240 & A & 24 & 3 & $S$ & $\bar{D}$ & 1,995 & 2,214 \\
\hline 1,862 & 120 & 24 & 0.4 & 240 & $\bar{A}$ & 24 & 3 & $S$ & $\bar{D}$ & 1,903 & 2,112 \\
\hline 1,863 & 120 & 24 & 0.4 & 240 & $\mathrm{~S}$ & 24 & 3 & 1 & $\bar{D}$ & 1,880 & 2,087 \\
\hline 1,864 & 120 & 24 & 0.4 & 240 & $\mathrm{~s}$ & 24 & 3 & $\mathrm{~T}$ & D & 1,883 & 2,090 \\
\hline 1,865 & 120 & 24 & & 240 & $\mathrm{~S}$ & & 5 & I & D & 1,236 & 1,483 \\
\hline 1,866 & 120 & 24 & 0.6 & 240 & $S$ & 20 & 3 & 1 & D & 1,889 & 2,097 \\
\hline 1,867 & 120 & 24 & 0.4 & 240 & S & 24 & 3 & $\mathrm{~S}$ & D & 1,601 & 1,777 \\
\hline 1,868 & 120 & 24 & 0.4 & 240 & $S$ & 24 & 3 & $S$ & D & 1,603 & 1,779 \\
\hline 1,869 & 120 & 24 & 0.6 & 240 & $\mathrm{~s}$ & 20 & 3 & $\mathrm{~S}$ & D & 1,604 & 1,780 \\
\hline 1,870 & 120 & 27 & 0.4 & 240 & $A$ & 24 & 3 & 1 & D & 2,354 & 2,613 \\
\hline 1,871 & 120 & 27 & 0.4 & 240 & A & 24 & 3 & $T$ & $\bar{D}$ & 2,263 & 2,512 \\
\hline 1,872 & 120 & 27 & & 240 & A & 24 & 3 & 1 & $\mathrm{R}$ & 4,379 & 2,785 \\
\hline 1,873 & 120 & 27 & & 480 & $A$ & 24 & 3 & I & $R$ & 4,486 & 2,853 \\
\hline 1,874 & 120 & 27 & 0.4 & 240 & A & 24 & 3 & $\mathrm{~S}$ & $\mathrm{D}$ & 2,002 & 2,222 \\
\hline 1,875 & 120 & 27 & 0.4 & 240 & A & 24 & 3 & $S$ & $\bar{D}$ & 1,910 & 2,120 \\
\hline 1,876 & 120 & 27 & & 240 & A & 24 & 3 & $\mathrm{~S}$ & R & 3,790 & 2,410 \\
\hline 1,877 & 120 & 27 & & 480 & $A$ & 24 & 3 & $S$ & $\bar{R}$ & 3,843 & 2,444 \\
\hline 1,878 & 120 & 27 & & 240 & $S$ & 16 & 5 & 1 & $\bar{D}$ & 2,188 & 2,429 \\
\hline 1,879 & 120 & 27 & & 240 & S & 16 & 3 & 1 & D & 1,963 & 2,179 \\
\hline 1,880 & 120 & 27 & 0.4 & 240 & $\bar{S}$ & 24 & 3 & 1 & $D$ & 1,960 & 2,176 \\
\hline 1,881 & 120 & 27 & 0.4 & 240 & $S$ & 24 & 3 & $\mathrm{I}$ & $\bar{D}$ & 1,963 & 2,179 \\
\hline 1,882 & 120 & 27 & 0.6 & 240 & $\mathrm{~S}$ & 20 & 3 & 1 & $D$ & 1,965 & 2,181 \\
\hline 1,883 & 120 & 27 & & 240 & $\mathrm{~S}$ & 24 & 3 & 1 & $R$ & 3,529 & 2,244 \\
\hline 1,884 & 120 & 27 & & 480 & $S$ & 24 & 3 & 1 & $\mathrm{R}$ & 3,636 & 2,312 \\
\hline 1,885 & 120 & 27 & & 240 & $\mathrm{~S}$ & 16 & 5 & $s$ & D & 1,835 & 2,037 \\
\hline 1,886 & 120 & 27 & & 240 & $\mathrm{~S}$ & 16 & 3 & $S$ & D & 1,610 & 1,787 \\
\hline 1,887 & 120 & 27 & 0.4 & 240 & $\mathrm{~S}$ & 24 & 3 & S & D & 1,608 & 1,785 \\
\hline 1,888 & 120 & 27 & 0.4 & 240 & $S$ & 24 & 3 & $\mathbf{S}$ & D & 1,610 & 1,787 \\
\hline 1,889 & 120 & 27 & 0.6 & 240 & $S$ & 20 & 3 & S & D & 1,611 & 1,788 \\
\hline 1,890 & 120 & 27 & & 240 & $S$ & 24 & 3 & S & $R$ & 2,940 & 1,870 \\
\hline 1,891 & 120 & 27 & & 480 & $\mathrm{~S}$ & 24 & 3 & $S$ & $\mathbf{R}$ & 2,993 & 1,904 \\
\hline
\end{tabular}


Table A.3. Electric Storage Water Heaters (contd)

\begin{tabular}{|c|c|c|c|c|c|c|c|c|c|c|c|}
\hline REC & VOL & INP & STBY & VOLT & TANK & RVAL & WARR & THERM & CTYPE & LCOST & CCOST \\
\hline 1,892 & 120 & 30 & 0.4 & 240 & A & 24 & 3 & 1 & D & 2,394 & 2,657 \\
\hline 1,893 & 120 & 30 & 0.4 & 240 & $A$ & 24 & 3 & 1 & $\bar{D}$ & 2,308 & 2,562 \\
\hline 1,894 & 120 & 30 & 0.6 & 240 & $A$ & 16 & 3 & 1 & $\mathrm{D}$ & 2,534 & 2,813 \\
\hline 1,895 & 120 & 30 & 0.4 & 240 & $\bar{A}$ & 24 & 3 & $S$ & $\bar{D}$ & 2,014 & 2,235 \\
\hline 1,896 & 120 & 30 & 0.4 & 240 & $A$ & 24 & 3 & $\mathbf{S}$ & D & 1,922 & 2,133 \\
\hline 1,897 & 120 & 30 & & 240 & $S$ & 16 & 5 & $T$ & $\bar{D}$ & 2,233 & 2,479 \\
\hline 1,898 & 120 & 30 & & 240 & $S$ & 16 & 3 & 1 & $D$ & 2,008 & 2,229 \\
\hline 1,899 & 120 & 30 & 0.4 & 240 & $S$ & 24 & 3 & 1 & $\bar{D}$ & 2,000 & 2,220 \\
\hline 1,900 & 120 & 30 & 0.4 & 240 & $\mathbf{S}$ & 24 & 3 & I & D & 2,008 & 2,229 \\
\hline 1,901 & 120 & 30 & & 240 & $S$ & & 5 & $\mathrm{~T}$ & $\bar{D}$ & 1,311 & 1,573 \\
\hline 1,902 & 120 & 30 & 0.6 & 240 & $S$ & 20 & 3 & 1 & D & 2,010 & 2,231 \\
\hline 1,903 & 120 & 30 & & 240 & $s$ & 16 & 5 & $S$ & $\mathrm{D}$ & 1,847 & 2,050 \\
\hline $.1,904$ & 120 & 30 & & 240 & $S$ & 16 & 3 & $\mathrm{~S}$ & $D$ & 1,622 & 1,800 \\
\hline 1,905 & 120 & 30 & 0.4 & 240 & $S$ & 24 & 3 & $S$ & $\mathrm{D}$ & 1,620 & 1,798 \\
\hline 1,906 & 120 & 30 & 0.4 & 240 & $S$ & 24 & 3 & $S$ & $\mathrm{D}$ & 1,622 & 1,800 \\
\hline 1,907 & 120 & 30 & 0.6 & 240 & S & 20 & 3 & $\mathbf{S}$ & D & 1,623 & 1,802 \\
\hline 1,908 & 120 & 36 & 0.4 & 240 & A & 24 & 3 & 1 & $\bar{D}$ & 2,433 & 2,700 \\
\hline 1,909 & 120 & 36 & 0.4 & 240 & $\mathrm{~A}$ & 24 & 3 & $I$ & $D$ & 2,344 & 2,602 \\
\hline 1,910 & 120 & 36 & & 240 & A & 24 & 3 & 1 & $R$ & 4,461 & 2,837 \\
\hline 1,911 & 120 & 36 & & 480 & $\bar{A}$ & 24 & 3 & I & $\bar{R}$ & 4,624 & 2,941 \\
\hline 1,912 & 120 & 36 & 0.6 & 240 & A & 16 & 3 & 1 & $D$ & 2,594 & 2,879 \\
\hline 1,913 & 120 & 36 & 0.4 & 240 & $\bar{A}$ & 24 & 3 & $S$ & $D$ & 2,023 & 2,245 \\
\hline 1,914 & 120 & 36 & 0.4 & 240 & A & 24 & 3 & $S$ & D & 1,932 & 2,145 \\
\hline 1,915 & 120 & 36 & & 240 & $\bar{A}$ & 24 & 3 & $S$ & $\mathbf{R}$ & 3,835 & 2,439 \\
\hline 1,916 & 120 & 36 & & 480 & $A$ & 24 & 3 & $S$ & $R$ & 3,899 & 2,480 \\
\hline 1,917 & 120 & 36 & & 240 & $S$ & 16 & 5 & 1 & $\mathrm{D}$ & 2,269 & 2,519 \\
\hline 1,918 & 120 & 36 & & 240 & $S$ & 16 & 3 & 1 & D & 2,044 & 2,269 \\
\hline 1,919 & 120 & 36 & 0.4 & 240 & $S$ & 24 & 3 & 1 & D & 2,039 & 2,263 \\
\hline 1,920 & 120 & 36 & 0.4 & 240 & $S$ & 24 & 3 & 1 & D & 2,044 & 2,269 \\
\hline 1,921 & 120 & 36 & & 240 & 5 & & 5 & 1 & $D$ & 1,432 & 1,718 \\
\hline 1,922 & 120 & 36 & 0.6 & 240 & $S$ & 20 & 3 & 1 & D & 2,046 & 2,271 \\
\hline 1,923 & 120 & 36 & & 240 & $S$ & 24 & 3 & 1 & $\mathrm{R}$ & 3,611 & 2,297 \\
\hline 1,924 & 120 & 36 & & 480 & $S$ & 24 & 3 & 1 & $\mathbf{R}$ & 3,774 & 2,400 \\
\hline 1,925 & 120 & 36 & & 240 & $S$ & 16 & 5 & $S$ & $\bar{D}$ & 1,857 & 2,061 \\
\hline 1,926 & 120 & 36 & & 240 & $S$ & 16 & 3 & $S$ & D & 1,632 & 1,812 \\
\hline 1,927 & 120 & 36 & 0.4 & 240 & $S$ & 24 & 3 & $S$ & $\bar{D}$ & 1,629 & 1,808 \\
\hline 1,928 & 120 & 36 & 0.4 & 240 & $S$ & 24 & 3 & $S$ & D & 1,632 & 1,812 \\
\hline 1,929 & 120 & 36 & 0.6 & 240 & $S$ & 20 & 3 & $S$ & $D$ & 1,634 & 1,814 \\
\hline 1,930 & 120 & 36 & & 240 & $S$ & 24 & 3 & $S$ & $R$ & 2,985 & 1,898 \\
\hline 1,931 & 120 & 36 & & 480 & $S$ & 24 & 3 & $S$ & $R$ & 3,049 & 1,939 \\
\hline 1,932 & 120 & 41 & 0.6 & 240 & $S$ & 20 & 3 & 1 & D & 2,456 & 2,726 \\
\hline 1,933 & 120 & 41 & 0.6 & 240 & $S$ & 20 & 3 & $S$ & D & 2,089 & 2,319 \\
\hline 1,934 & 120 & 45 & 0.4 & 240 & A & 24 & 3 & $T$ & D & 2,844 & 3,157 \\
\hline 1,935 & 120 & 45 & 0.4 & 240 & $A$ & 24 & 3 & 1 & $D$ & 2,754 & 3,057 \\
\hline 1,936 & 120 & 45 & & 240 & $A$ & 24 & 3 & 1 & $\mathrm{R}$ & 5,138 & 3,268 \\
\hline
\end{tabular}


Table A.3. Electric Storage Water Heaters (contd)

\begin{tabular}{|c|c|c|c|c|c|c|c|c|c|c|c|}
\hline REC & VOL & INP & STBY & VOLT & TANK & RVAL & WARR & THERM & CTYPE & LCOST & CCOST \\
\hline 1,937 & 120 & 45 & & 480 & $A$ & 24 & 3 & 1 & $R$ & 5,173 & 3,290 \\
\hline 1,938 & 120 & 45 & 0.6 & 240 & A & 16 & 3 & 1 & D & 2,949 & 3,273 \\
\hline 1,939 & 120 & 45 & 0.4 & 240 & A & 24 & 3 & $\mathrm{~S}$ & D & 2,478 & 2,750 \\
\hline 1,940 & 120 & 45 & 0.4 & 240 & $A$ & 24 & 3 & $S$ & $D$ & 2,383 & 2,645 \\
\hline 1,941 & 120 & 45 & & 240 & A & 24 & 3 & $S$ & $\mathrm{R}$ & 4,574 & 2,909 \\
\hline 1,942 & 120 & 45 & & 480 & $\bar{A}$ & 24 & 3 & $S$ & $\mathrm{R}$ & 4,618 & 2,937 \\
\hline 1,943 & 120 & 45 & & 240 & $S$ & 16 & 5 & 1 & D & 2,679 & 2,974 \\
\hline 1,944 & 120 & 45 & & 240 & $S$ & 16 & 3 & 1 & D & 2,454 & 2,724 \\
\hline 1,945 & 120 & 45 & 0.4 & 240 & $S$ & 24 & 3 & 1 & $D$ & 2,450 & 2,720 \\
\hline 1,946 & 120 & 45 & 0.4 & 240 & $S$ & 24 & 3 & 1 & D & 2,454 & 2,724 \\
\hline 1,947 & 120 & 45 & 0.6 & 240 & $S$ & 20 & 3 & 1 & $D$ & 2,456 & 2,726 \\
\hline 1,948 & 120 & 45 & & 240 & $\mathrm{~S}$ & 24 & 3 & 1 & $\mathbf{R}$ & 4,288 & 2,727 \\
\hline 1,949 & 120 & 45 & & 480 & $S$ & 24 & 3 & 1 & $R$ & 4,323 & 2,749 \\
\hline 1,950 & 120 & 45 & & 240 & $S$ & 16 & 5 & $S$ & $\mathrm{D}$ & 2,308 & 2,562 \\
\hline 1,951 & 120 & 45 & & 240 & $S$ & 16 & 3 & $S$ & D & 2,083 & 2,312 \\
\hline 1,952 & 120 & 45 & 0.4 & 240 & $S$ & 24 & 3 & $S$ & $\mathrm{D}$ & 2,084 & 2,313 \\
\hline 1,953 & 120 & 45 & 0.4 & 240 & $S$ & 24 & 3 & $S$ & D & 2,083 & 2,312 \\
\hline 1,954 & 120 & 45 & 0.6 & 240 & $S$ & 20 & 3 & $S$ & $D$ & 2,084 & 2,313 \\
\hline 1,955 & 120 & 45 &. & 240 & 5 & 24 & 3 & $S$ & $R$ & 3,724 & 2,368 \\
\hline 1,956 & 120 & 45 & & 480 & $S$ & 24 & 3 & $S$ & $\mathbf{R}$ & 3,768 & 2,396 \\
\hline 1,957 & 120 & 48 & & 240 & $S$ & & 5 & 1 & $D$ & 1,455 & 1,746 \\
\hline 1,958 & 120 & 52 & & 240 & $S$ & & 5 & 1 & D & 1,501 & 1,801 \\
\hline 1,959 & 120 & 54 & 0.4 & 240 & A & 24 & 3 & 1 & D & 2,916 & 3,236 \\
\hline 1,960 & 120 & 54 & 0.4 & 240 & A & 24 & 3 & 1 & $\mathbf{R}$ & 2,820 & 3,130 \\
\hline 1,961 & 120 & 54 & & 240 & $\bar{A}$ & 24 & 3 & 1 & $\mathbf{R}$ & 5,225 & 3,323 \\
\hline 1,962 & 120 & 54 & & 480 & A & 24 & 3 & 1 & $\mathrm{R}$ & 5,294 & 3,367 \\
\hline 1,963 & 120 & 54 & 0.6 & 240 & A & 16 & 3 & I & $D$ & 2,985 & 3,313 \\
\hline 1,964 & 120 & 54 & 0.4 & 240 & A & 24 & 3 & $S$ & D & 2,494 & 2,768 \\
\hline 1,965 & 120 & 54 & 0.4 & 240 & A & 24 & 3 & $S$ & $R$ & 2,399 & 2,663 \\
\hline 1,966 & 120 & 54 & & 240 & A & 24 & 3 & S & $\mathrm{R}$ & 4,612 & 2,933 \\
\hline 1,967 & 120 & 54 & & 480 & $\bar{A}$ & 24 & 3 & $S$ & $R$ & 4,676 & 2,974 \\
\hline 1,968 & 120 & 54 & & 240 & $S$ & 16 & 5 & 1 & D & 2,745 & 3,047 \\
\hline 1,969 & 120 & 54 & & 240 & $S$ & 16 & 3 & 1 & D & 2,520 & 2,797 \\
\hline 1,970 & 120 & 54 & 0.4 & 240 & $S$ & 24 & 3 & 1 & D & 2,522 & 2,799 \\
\hline 1,971 & 120 & 54 & 0.4 & 240 & $S$ & 24 & 3 & 1 & D & 2,520 & 2,797 \\
\hline 1,972 & 120 & 54 & 0.6 & 240 & $\mathrm{~S}$ & 20 & 3 & 1 & D & 2,522 & 2,799 \\
\hline 1,973 & 120 & 54 & & 240 & $S$ & 24 & 3 & 1 & $\bar{R}$ & 4,375 & 2,783 \\
\hline 1,974 & 120 & 54 & & 480 & S & 24 & 3 & 1 & $R$ & 4,444 & 2,826 \\
\hline 1,975 & 120 & 54 & & 240 & $S$ & 16 & 5 & 5 & $D$ & 2,324 & 2,580 \\
\hline 1,976 & 120 & 54 & & 240 & $S$ & 16 & 3 & $S$ & D & 2,099 & 2,330 \\
\hline 1,977 & 120 & 54 & 0.4 & 240 & $S$ & 24 & 3 & $S$ & $D$ & 2,100 & 2,331 \\
\hline 1,978 & 120 & 54 & 0.4 & 240 & $S$ & 24 & 3 & $S$ & $D$ & 2,099 & 2,330 \\
\hline 1,979 & 120 & 54 & 0.6 & 240 & S & 20 & 3 & $S$ & D & 2,100 & 2,331 \\
\hline 1,980 & 120 & 54 & & 240 & $S$ & 24 & 3 & $S$ & $\mathrm{R}$ & 3,762 & 2,393 \\
\hline 1,981 & 120 & 54 & & 480 & $S$ & 24 & 3 & $s$ & $\mathrm{R}$ & 3,826 & 2,433 \\
\hline
\end{tabular}


Table A.3. Electric Storage Water Heaters (contd)

\begin{tabular}{|c|c|c|c|c|c|c|c|c|c|c|c|}
\hline REC & VOL & INP & STBY & VOLT & TANK & RVAL & WARR & THERM & CTYPE & LCOST & CCOST \\
\hline 1,982 & 120 & 81 & & 240 & $\mathrm{~s}$ & 16 & 5 & 1 & D & 4,085 & 4,534 \\
\hline 1,983 & 120 & 81 & & 240 & $S$ & 16 & 3 & 1 & D & 3,860 & 4,285 \\
\hline 1,984 & 130 & 15 & 0.6 & 240 & A & 12 & & 1 & D & 5,532 & 6,141 \\
\hline 1,985 & 130 & 15 & 0.6 & 480 & $\bar{A}$ & 12 & & 1 & D & 5,467 & 6,068 \\
\hline 1,986 & 130 & 24 & 0.6 & 240 & A & 12 & & 1 & D & 5,906 & 6,556 \\
\hline 1,987 & 130 & 24 & 0.6 & 480 & $\bar{A}$ & 12 & & 1 & $\bar{D}$ & 5,667 & 6,290 \\
\hline 1,988 & 130 & 30 & 0.6 & 240 & A & 12 & & 1 & $D$ & 6,104 & 6,775 \\
\hline 1,989 & 130 & 30 & 0.6 & 480 & $A$ & 12 & & 1 & D & 5,824 & 6,465 \\
\hline 1,990 & 130 & 36 & 0.6 & 240 & $\bar{A}$ & 12 & & 1 & D & 6,400 & 7,104 \\
\hline 1,991 & 130 & 36 & 0.6 & 480 & $\bar{A}$ & 12 & & I & D & 5,929 & 6,581 \\
\hline 1,992 & 130 & 45 & 0.6 & 240 & $\bar{A}$ & 12 & & 1 & $D$ & 6,661 & 7,394 \\
\hline 1,993 & 130 & 45 & 0.6 & 480 & $\bar{A}$ & 12 & & 1 & D & 6,084 & 6,753 \\
\hline 1,994 & 130 & 60 & 0.6 & 240 & $\bar{A}$ & 12 & & 1 & D & 6,897 & 7,656 \\
\hline 1,995 & 130 & 60 & 0.6 & 480 & $\mathrm{~A}$ & 12 & & 1 & $D$ & 6,508 & 7,224 \\
\hline 1,996 & 130 & 75 & 0.6 & 240 & A & 12 & & $\mathrm{I}$ & $\mathrm{D}$ & 7,536 & 8,365 \\
\hline 1,997 & 130 & 75 & 0.6 & 480 & $A$ & 12 & & 1 & $\mathrm{D}$ & 7,042 & 7,817 \\
\hline 1,998 & 130 & 90 & 0.6 & 240 & $\bar{A}$ & 12 & & $\mathrm{I}$ & $\bar{D}$ & 7,906 & 8,776 \\
\hline 1,999 & 130 & 90 & 0.6 & 480 & A & 12 & & I & D & 7,267 & 8,066 \\
\hline 2,000 & 130 & 105 & 0.6 & 240 & $A$ & 12 & & I & $\bar{D}$ & 8,499 & 9,434 \\
\hline 2,001 & 130 & 105 & 0.6 & 480 & $\bar{A}$ & 12 & & 1 & D & 7,834 & 8,696 \\
\hline 2,002 & 130 & 120 & 0.6 & 240 & $A$ & 12 & & 1 & $\bar{D}$ & 8,865 & 9,840 \\
\hline 2,003 & 130 & 120 & 0.6 & 480 & $\bar{A}$ & 12 & & 1 & $\bar{D}$ & 8,056 & 8,942 \\
\hline 2,004 & 150 & 15 & 0.6 & 240 & $\mathrm{~A}$ & 16 & 3 & 1 & $\mathbf{R}$ & 9,417 & 5,989 \\
\hline 2,005 & 150 & 15 & 0.5 & 240 & $\bar{A}$ & 12 & & I & $\bar{D}$ & 6,222 & 6,906 \\
\hline 2,006 & 150 & 15 & 0.5 & 480 & $A$ & 12 & & 1 & $\mathrm{D}$ & 6,151 & 6,828 \\
\hline 2,007 & 150 & 15 & 0.6 & 240 & $A$ & 16 & 3 & $S$ & $\mathbf{R}$ & 9,104 & 5,790 \\
\hline 2,008 & 150 & 18 & 0.6 & 240 & A & 16 & 3 & 1 & $\mathrm{R}$ & 9,877 & 6,282 \\
\hline 2,009 & 150 & 18 & 0.6 & 240 & $\bar{A}$ & 16 & 3 & $S$ & $\mathbf{R}$ & 9,392 & 5,973 \\
\hline 2,010 & 150 & 24 & 0.6 & 240 & A & & 3 & 1 & $\mathrm{D}$ & 6,640 & 7,370 \\
\hline 2,011 & 150 & 24 & 0.6 & 480 & A & & 3 & I & D & 6,453 & 7,163 \\
\hline 2,012 & 150 & 24 & 0.5 & 240 & A & 12 & & $I$ & D & 6,541 & 7,261 \\
\hline 2,013 & 150 & 24 & 0.5 & 480 & $A$ & 12 & & 1 & D & 6,364 & 7,064 \\
\hline 2,014 & 150 & 30 & 0.6 & 240 & $A$ & 16 & 3 & 1 & $R$ & 10,080 & 6,411 \\
\hline 2,015 & 150 & 30 & 0.5 & 240 & $A$ & 12 & & 1 & $\mathrm{D}$ & 6,671 & 7,405 \\
\hline 2,016 & 150 & 30 & 0.5 & 480 & A & 12 & & 1 & $\mathrm{D}$ & 6,502 & 7,217 \\
\hline 2,017 & 150 & 30 & 0.6 & 240 & $A$ & 16 & 3 & $S$ & $R$ & 9,580 & 6,093 \\
\hline 2,018 & 150 & 36 & 0.6 & 240 & A & & 3 & 1 & D & 7,090 & 7,870 \\
\hline 2,019 & 150 & 36 & 0.6 & 480 & $\bar{A}$ & & 3 & 1 & $D$ & 6,733 & 7,474 \\
\hline 2,020 & 150 & 36 & 0.6 & 240 & A & 16 & 3 & 1 & R & 10,580 & 6,729 \\
\hline 2,021 & 150 & 36 & 0.5 & 240 & A & 12 & & 1 & D & 6,987 & 7,756 \\
\hline 2,022 & 150 & 36 & 0.5 & 480 & A & 12 & & 1 & $D$ & 6,632 & 7,362 \\
\hline 2,023 & 150 & 36 & 0.6 & 240 & A & 16 & 3 & $S$ & $R$ & 10,054 & 6,394 \\
\hline 2,024 & 150 & 45 & 0.6 & 240 & $A$ & 16 & 3 & 1 & $\mathrm{R}$ & 10,774 & 6,852 \\
\hline 2,025 & 150 & 45 & 0.5 & 240 & $A$ & 12 & & I & D & 7,129 & 7,913 \\
\hline 2,026 & 150 & 45 & 0.5 & 480 & $A$ & 12 & & I & $\mathrm{D}$ & 6,897 & 7,656 \\
\hline
\end{tabular}


Table A.3. Electric Storage Water Heaters (contd)

\begin{tabular}{|c|c|c|c|c|c|c|c|c|c|c|c|}
\hline REC & VOL & INP & STBY & VOLT & TANK & RVAL & WARR & THERM & CTYPE & LCOST & CCOST \\
\hline 2,027 & 150 & 45 & 0.6 & 240 & $A$ & 16 & 3 & $\mathrm{~S}$ & $\mathrm{R}$ & 10,230 & 6,506 \\
\hline 2,028 & 150 & 54 & 0.6 & 240 & $\mathrm{~A}$ & 16 & 3 & I & $\mathbf{R}$ & 11,318 & 7,198 \\
\hline 2,029 & 150 & 54 & 0.6 & 240 & $\bar{A}$ & 16 & 3 & $S$ & $\mathbf{R}$ & 10,767 & 6,848 \\
\hline 2,030 & 150 & 60 & 0.5 & 240 & A & 12 & & $T$ & D & 7,499 & 8,324 \\
\hline 2,031 & 150 & 60 & 0.5 & 480 & A & 12 & & 1 & D & 7,108 & 7,890 \\
\hline 2,032 & 150 & 72 & 0.6 & 240 & A & 16 & 3 & $T$ & $\mathbf{R}$ & 12,250 & 7,791 \\
\hline 2,033 & 150 & 72 & 0.6 & 240 & A & 16 & 3 & $S$ & $\mathbf{R}$ & 11,643 & 7,405 \\
\hline 2,034 & 150 & 75 & 0.6 & 240 & A & & 3 & 1 & D & 8,253 & 9,161 \\
\hline 2,035 & 150 & 75 & 0.6 & 480 & A & & 3 & 1 & $D$ & 7,759 & 8,612 \\
\hline 2,036 & 150 & 75 & 0.5 & 240 & $\bar{A}$ & 12 & & 1 & $D$ & 8,125 & 9,019 \\
\hline 2,037 & 150 & 75 & 0.5 & 480 & A & 12 & & 1 & D & 7,643 & 8,484 \\
\hline 2,038 & 150 & 90 & 0.6 & 240 & A & 16 & 3 & 1 & $R$ & 12,806 & 8,145 \\
\hline 2,039 & 150 & 90 & 0.5 & 240 & A & 12 & & 1 & $\mathrm{D}$ & 8,499 & 9,434 \\
\hline 2,040 & 150 & 90 & 0.5 & 480 & A & 12 & & $\mathrm{I}$ & $D$ & 7,879 & 8,746 \\
\hline 2,041 & 150 & 90 & 0.6 & 240 & A & 16 & 3 & $S$ & $R$ & 12,169 & 7,739 \\
\hline 2,042 & 150 & 105 & 0.6 & 240 & A & & 3 & 1 & $D$ & 9,250 & 10,268 \\
\hline 2,043 & 150 & 105 & 0.6 & 480 & $\bar{A}$ & & 3 & 1 & D & 8,563 & 9,505 \\
\hline 2,044 & 150 & 105 & 0.5 & 240 & A & 12 & & 1 & D & 9,107 & 10,109 \\
\hline 2,045 & 150 & 105 & 0.5 & 480 & A & 12 & & I & $D$ & 8,431 & 9,358 \\
\hline 2,046 & 150 & 108 & 0.6 & 240 & A & 16 & 3 & 1 & $R$ & 13,738 & 8,737 \\
\hline 2,047 & 150 & 108 & 0.6 & 240 & $A$ & 16 & 3 & $S$ & $R$ & 13,050 & 8,300 \\
\hline 2,048 & 150 & 120 & 0.6 & 240 & A & & 3 & 1 & D & 9,621 & 10,679 \\
\hline 2,049 & 150 & 120 & 0.6 & 480 & A & & 3 & 1 & $\mathrm{D}$ & 8,779 & 9,745 \\
\hline 2,050 & 150 & 120 & 0.5 & 240 & A & 12 & & 1 & D & 9,474 & 10,516 \\
\hline 2,051 & 150 & 120 & 0.5 & 480 & A & 12 & & 1 & $D$ & 8,644 & 9,595 \\
\hline 2,052 & 150 & 144 & 0.6 & 240 & A & 16 & 3 & 1 & $\mathrm{R}$ & 14,294 & 9,091 \\
\hline 2,053 & 150 & 144 & 0.6 & 240 & A & 16 & 3 & $S$ & $\mathrm{R}$ & 13,582 & 8,638 \\
\hline 2,054 & 150 & 150 & 0.6 & 240 & A & & 3 & 1 & D & 10,559 & 11,720 \\
\hline 2,055 & 150 & 150 & 0.6 & 480 & A & & 3 & $\mathrm{I}$ & D & 9,437 & 10,475 \\
\hline 2,056 & 150 & 150 & 0.5 & 240 & A & 12 & & 1 & $\bar{D}$ & 10,395 & 11,538 \\
\hline 2,057 & 150 & 150 & 0.5 & 480 & A & 12 & & 1 & D & 9,291 & 10,313 \\
\hline 2,058 & 200 & 15 & 0.6 & 240 & A & 16 & 3 & 1 & $R$ & 10,304 & 6,553 \\
\hline 2,059 & 200 & 15 & 0.6 & 240 & A & 16 & 3 & $S$ & $\mathrm{R}$ & 10,154 & 6,458 \\
\hline 2,060 & 200 & 18 & 0.6 & 240 & $A$ & 16 & 3 & 1 & $\mathbf{R}$ & 10,336 & 6,574 \\
\hline 2,061 & 200 & 18 & 0.6 & 240 & A & 16 & 3 & $S$ & $\mathrm{R}$ & 9,841 & 6,259 \\
\hline 2,062 & 200 & 30 & 0.5 & 240 & A & & 3 & 1 & $D$ & 6,931 & 7,693 \\
\hline 2,063 & 200 & 30 & 0.5 & 480 & A & & 3 & 1 & D & 6,810 & 7,559 \\
\hline 2,064 & 200 & 30 & 0.5 & 240 & A & & 3 & 1 & D & 7,726 & 8,576 \\
\hline 2,065 & 200 & 30 & 0.5 & 480 & A & & 3 & 1 & $D$ & 7,605 & 8,442 \\
\hline 2,066 & 200 & 30 & 0.6 & 240 & A & 16 & 3 & 1 & $R$ & 10,349 & 6,582 \\
\hline 2,067 & 200 & 30 & 0.6 & 240 & A & 16 & 3 & $S$ & $R$ & 9,999 & 6,359 \\
\hline 2,068 & 200 & 36 & 0.6 & 240 & A & 16 & 3 & 1 & $R$ & 10,770 & 6,850 \\
\hline 2,069 & 200 & 36 & 0.6 & 240 & A & 16 & 3 & $S$ & $\mathrm{R}$ & 10,230 & 6,506 \\
\hline 2,070 & 200 & 45 & 0.6 & 240 & A & 16 & 3 & 1 & $\mathrm{R}$ & 10,805 & 6,872 \\
\hline 2,071 & 200 & 45 & 0.6 & 240 & A & 16 & 3 & $S$ & $R$ & 10,267 & 6,530 \\
\hline
\end{tabular}


Table A.3. Electric Storage Water Heaters (contd)

\begin{tabular}{|c|c|c|c|c|c|c|c|c|c|c|c|}
\hline REC & VOL & INP & STBY & VOLT & TANK & RVAL & WARR & THERM & CTYPE & LCOST & CCOST \\
\hline 2,072 & 200 & 54 & 0.6 & 240 & $\mathrm{~A}$ & 16 & 3 & 1 & $\mathrm{R}$ & 11,879 & 7,555 \\
\hline 2,073 & 200 & 54 & 0.6 & 240 & $\bar{A}$ & 16 & 3 & $S$ & $R$ & 11,286 & 7,178 \\
\hline 2,074 & 200 & 60 & 0.5 & 240 & A & & 3 & 1 & D & 7,955 & 8,830 \\
\hline 2,075 & 200 & 60 & 0.5 & 480 & $\mathrm{~A}$ & & 3 & $\mathrm{I}$ & $\mathrm{D}$ & 7,554 & 8,385 \\
\hline 2,076 & 200 & 60 & 0.5 & 240 & A & & 3 & 1 & D & 8,750 & 9,713 \\
\hline 2,077 & 200 & 60 & 0.5 & 480 & $\bar{A}$ & & 3 & $T$ & $\bar{D}$ & 8,349 & 9,267 \\
\hline 2,078 & 200 & 72 & 0.6 & 240 & A & 16 & 3 & 1 & $\mathbf{R}$ & 12,993 & 8,264 \\
\hline 2,079 & 200 & 72 & 0.6 & 240 & A & 16 & 3 & $S$ & $R$ & 12,343 & 7,850 \\
\hline 2,080 & 200 & 90 & 0.5 & 240 & $\bar{A}$ & & 3 & 1 & D & 9,116 & 10,119 \\
\hline 2,081 & 200 & 90 & 0.5 & 480 & $A$ & & 3 & 1 & D & 8,482 & 9,415 \\
\hline 2,082 & 200 & 90 & 0.5 & 240 & $\bar{A}$ & & 3 & $T$ & $\mathrm{D}$ & 9,911 & 11,001 \\
\hline 2,083 & 200 & 90 & 0.5 & 480 & 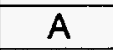 & & 3 & 1 & D & 9,277 & 10,297 \\
\hline 2,084 & 200 & 90 & 0.6 & 240 & A & 16 & 3 & 1 & $\mathrm{R}$ & 13,549 & 8,617 \\
\hline 2,085 & 200 & 90 & 0.6 & 240 & $\bar{A}$ & 16 & 3 & $S$ & $\mathrm{R}$ & 12,875 & 8,189 \\
\hline 2,086 & 200 & 105 & 0.5 & 240 & $\bar{A}$ & & 3 & 1 & D & 9,725 & 10,795 \\
\hline 2,087 & 200 & 105 & 0.5 & 480 & A & & 3 & 1 & D & 9,039 & 10,033 \\
\hline 2,088 & 200 & 105 & 0.5 & 240 & $\bar{A}$ & & 3 & 1 & D & 10,520 & 11,677 \\
\hline 2,089 & 200 & 105 & 0.5 & 480 & $\bar{A}$ & & 3 & 1 & $\mathrm{D}$ & 9,834 & 10,916 \\
\hline 2,090 & 200 & 108 & 0.6 & 240 & A & 16 & 3 & 1 & $R$ & 14,482 & 9,211 \\
\hline 2,091 & 200 & 108 & 0.6 & 240 & A & 16 & 3 & $S$ & $R$ & 13,743 & 8,741 \\
\hline 2,092 & 200 & 120 & 0.5 & 240 & $\bar{A}$ & & 3 & 1 & $\bar{D}$ & 10,091 & 11,201 \\
\hline 2,093 & 200 & 120 & 0.5 & 480 & A & & 3 & 1 & $\bar{D}$ & 9,253 & 10,271 \\
\hline 2,094 & 200 & 120 & 0.5 & 240 & A & & 3 & 1 & D & 10,886 & 12,083 \\
\hline 2,095 & 200 & 120 & 0.5 & 480 & $\bar{A}$ & & 3 & 1 & $\bar{D}$ & 10,048 & 11,153 \\
\hline 2,096 & 200 & 144 & 0.6 & 240 & A & 16 & 3 & 1 & $R$ & 15,045 & 9,569 \\
\hline 2,097 & 200 & 144 & 0.6 & 240 & A & 16 & 3 & $S$ & $R$ & 14,281 & 9,083 \\
\hline 2,098 & 200 & 180 & 0.5 & 240 & $\bar{A}$ & & 3 & 1 & $D$ & 11,592 & 12,867 \\
\hline 2,099 & 200 & 180 & 0.5 & 480 & A & & 3 & 1 & D & 10,518 & 11,675 \\
\hline 2,100 & 200 & 180 & 0.5 & 240 & $\mathrm{~A}$ & & 3 & 1 & D & 12,387 & 13,750 \\
\hline 2,101 & 200 & 180 & 0.5 & 480 & $\bar{A}$ & & 3 & 1 & D & 11,313 & 12,557 \\
\hline 2,102 & 250 & 15 & 0.5 & 240 & A & 16 & 3 & 1 & $\mathrm{R}$ & 10,580 & 6,729 \\
\hline 2,103 & 250 & 15 & 0.5 & 240 & A & 16 & 3 & $\mathrm{~S}$ & $\mathbf{R}$ & 10,612 & 6,749 \\
\hline 2,104 & 250 & 18 & 0.5 & 240 & A & 16 & 3 & 1 & $\mathbf{R}$ & 10,642 & 6,768 \\
\hline 2,105 & 250 & 18 & 0.5 & 240 & $\bar{A}$ & 16 & 3 & $S$ & $\mathbf{R}$ & 11,372 & 7,233 \\
\hline 2,106 & 250 & 30 & 0.5 & 240 & A & & 3 & 1 & $D$ & 7,185 & 7,975 \\
\hline 2,107 & 250 & 30 & 0.5 & 480 & $\bar{A}$ & & 3 & 1 & $\bar{D}$ & 7,049 & 7,824 \\
\hline 2,108 & 250 & 30 & 0.5 & 240 & A & & 3 & I & D & 7,980 & 8,858 \\
\hline 2,109 & 250 & 30 & 0.5 & 480 & $\bar{A}$ & & 3 & 1 & $D$ & 7,844 & 8,707 \\
\hline 2,110 & 250 & 30 & 0.5 & 240 & A & 16 & 3 & 1 & $R$ & 10,692 & 6,800 \\
\hline 2,111 & 250 & 30 & 0.5 & 240 & $A$ & 16 & 3 & $S$ & $R$ & 10,217 & 6,498 \\
\hline 2,112 & 250 & 36 & 0.5 & 240 & $A$ & 16 & 3 & 1 & $\mathrm{R}$ & 11,231 & 7,143 \\
\hline 2,113 & 250 & 36 & 0.5 & 240 & A & 16 & 3 & $S$ & $R$ & 10,668 & 6,785 \\
\hline 2,114 & 250 & 45 & 0.5 & 240 & A & 16 & 3 & 1 & $\mathbf{R}$ & 11,693 & 7,437 \\
\hline 2,115 & 250 & 45 & 0.5 & 240 & A & 16 & 3 & $S$ & $\mathrm{R}$ & 11,106 & 7,063 \\
\hline 2,116 & 250 & 54 & 0.5 & 240 & $\bar{A}$ & 16 & 3 & 1 & $\mathbf{R}$ & 12,442 & 7,913 \\
\hline
\end{tabular}


Table A.3. Electric Storage Water Heaters (contd)

\begin{tabular}{|c|c|c|c|c|c|c|c|c|c|c|c|}
\hline REC & VOL & INP & STBY & VOLT & TANK & RVAL & WARR & THERM & CTYPE & LCOST & CCOST \\
\hline 2,117 & 250 & 54 & 0.5 & 240 & $A$ & 16 & 3 & $S$ & $R$ & 11,813 & 7,513 \\
\hline 2,118 & 250 & 60 & 0.5 & 240 & $\bar{A}$ & & 3 & 1 & D & 8,287 & 9,199 \\
\hline 2,119 & 250 & 60 & 0.5 & 480 & $A$ & & 3 & $T$ & $\bar{D}$ & 7,943 & 8,817 \\
\hline 2,120 & 250 & 60 & 0.5 & 240 & A & & 3 & $T$ & D & 9,082 & 10,081 \\
\hline 2,121 & 250 & 60 & 0.5 & 480 & A & & 3 & 1 & D & 8,738 & 9,699 \\
\hline 2,122 & 250 & 72 & 0.5 & 240 & $A$ & 16 & 3 & 1 & $\mathbf{R}$ & 13,406 & 8,526 \\
\hline 2,123 & 250 & 72 & 0.5 & 240 & A & 16 & 3 & $S$ & $\mathbf{R}$ & 12,881 & 8,192 \\
\hline 2,124 & 250 & 90 & 0.5 & 240 & $A$ & & 3 & $T$ & $D$ & 9,371 & 10,402 \\
\hline 2,125 & 250 & 90 & 0.5 & 480 & $A$ & & 3 & 1 & D & 8,730 & 9,690 \\
\hline 2,126 & 250 & 90 & 0.5 & 240 & $\bar{A}$ & & 3 & I & D & 10,166 & 11,284 \\
\hline 2,127 & 250 & 90 & 0.5 & 480 & A & & 3 & 1 & D & 9,525 & 10,573 \\
\hline 2,128 & 250 & 90 & 0.5 & 240 & $\bar{A}$ & 16 & 3 & 1 & $\mathbf{R}$ & 14,007 & 8,908 \\
\hline 2,129 & 250 & 90 & 0.5 & 240 & A & 16 & 3 & $S$ & $R$ & 13,313 & 8,467 \\
\hline 2,130 & 250 & 108 & 0.5 & 240 & A & 16 & 3 & $\mathrm{~T}$ & $\mathbf{R}$ & 14,419 & 9,170 \\
\hline 2,131 & 250 & 108 & 0.5 & 240 & A & 16 & 3 & $\mathrm{~S}$ & $\mathrm{R}$ & 14,106 & 8,971 \\
\hline 2,132 & 250 & 120 & 0.5 & 240 & $A$ & & 3 & 1 & $D$ & 10,344 & 11,482 \\
\hline 2,133 & 250 & 120 & 0.5 & 480 & $\bar{A}$ & & 3 & 1 & D & 9,513 & 10,559 \\
\hline 2,134 & 250 & 120 & 0.5 & 240 & $A$ & & 3 & $\mathrm{I}$ & $\bar{D}$ & 11,139 & 12,364 \\
\hline 2,135 & 250 & 120 & 0.5 & 480 & A & & 3 & 1 & D & 10,308 & 11,442 \\
\hline 2,136 & 250 & 144 & 0.5 & 240 & $A$ & 16 & 3 & I & $R$ & 15,407 & 9,799 \\
\hline 2,137 & 250 & 144 & 0.5 & 240 & $\mathrm{~A}$ & 16 & 3 & $S$ & $R$ & 14,645 & 9,314 \\
\hline 2,138 & 250 & 180 & 0.5 & 240 & A & & 3 & $T$ & D & 11,823 & 13,124 \\
\hline 2,139 & 250 & 180 & 0.5 & 480 & A & & 3 & 1 & D & 10,753 & 11,936 \\
\hline 2,140 & 250 & 180 & 0.5 & 240 & $\bar{A}$ & & 3 & 1 & $D$ & 12,618 & 14,006 \\
\hline 2,141 & 250 & 180 & 0.5 & 480 & A & & 3 & 1 & D & 11,548 & 12,818 \\
\hline 2,142 & 250 & 240 & 0.5 & 240 & $\bar{A}$ & & 3 & 1 & D & 14,033 & 15,577 \\
\hline 2,143 & 250 & 240 & 0.5 & 480 & A & & 3 & 1 & D & 12,042 & 13,367 \\
\hline 2,144 & 250 & 240 & 0.5 & 240 & $A$ & & 3 & $T$ & D & 14,828 & 16,459 \\
\hline 2,145 & 250 & 240 & 0.5 & 480 & A & & 3 & $\mathrm{~T}$ & D & 12,837 & 14,249 \\
\hline 2,146 & 300 & 15 & 0.4 & 240 & A & 16 & 3 & 1 & $R$ & 11,274 & 7,170 \\
\hline 2,147 & 300 & 15 & 0.4 & 240 & $A$ & 16 & 3 & 5 & $\mathbf{R}$ & 12,442 & 7,913 \\
\hline 2,148 & 300 & 18 & 0.4 & 240 & $A$ & 16 & 3 & $T$ & $\mathbf{R}$ & 11,693 & 7,437 \\
\hline 2,149 & 300 & 18 & 0.4 & 240 & $\bar{A}$ & 16 & 3 & $S$ & $\mathrm{R}$ & 11,111 & 7,067 \\
\hline 2,150 & 300 & 30 & 0.4 & 240 & $A$ & 16 & 3 & 1 & $R$ & 11,730 & 7,460 \\
\hline 2,151 & 300 & 30 & 0.4 & 240 & A & 16 & 3 & 5 & $R$ & 11,148 & 7,090 \\
\hline 2,152 & 300 & 36 & 0.4 & 240 & $\bar{A}$ & 16 & 3 & $T$ & $\mathbf{R}$ & 11,768 & 7,484 \\
\hline 2,153 & 300 & 36 & 0.4 & 240 & A & 16 & 3 & $\mathrm{~S}$ & $R$ & 11,180 & 7,110 \\
\hline 2,154 & 300 & 45 & 0.4 & 240 & A & & 3 & 1 & D & 8,140 & 9,035 \\
\hline 2,155 & 300 & 45 & 0.4 & 480 & A & & 3 & 1 & $D$ & 7,884 & 8,751 \\
\hline 2,156 & 300 & 45 & 0.4 & 240 & $A$ & & 3 & 1 & D & 8,935 & 9,918 \\
\hline 2,157 & 300 & 45 & 0.4 & 480 & $A$ & & 3 & 1 & D & 8,679 & 9,634 \\
\hline 2,158 & 300 & 45 & 0.4 & 240 & A & 16 & 3 & $T$ & $\bar{R}$ & 12,118 & 7,707 \\
\hline 2,159 & 300 & 45 & 0.4 & 240 & $\bar{A}$ & 16 & 3 & 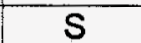 & $R$ & 11,518 & 7,325 \\
\hline 2,160 & 300 & 54 & 0.4 & 240 & $A$ & 16 & 3 & $T$ & $\mathbf{R}$ & 12,956 & 8,240 \\
\hline 2,161 & 300 & 54 & 0.4 & 240 & $A$ & 16 & 3 & $S$ & $\mathrm{R}$ & 12,312 & 7,830 \\
\hline
\end{tabular}


Table A.3. Electric Storage Water Heaters (contd)

\begin{tabular}{|c|c|c|c|c|c|c|c|c|c|c|c|}
\hline REC & VOL & INP & STBY & VOLT & TANK & RVAL & WARR & THERM & CTYPE & LCOST & CCOST \\
\hline 2,162 & 300 & 72 & 0.4 & 240 & $A$ & 16 & 3 & 1 & $R$ & 13,919 & 8,852 \\
\hline 2,163 & 300 & 72 & 0.4 & 240 & $A$ & 16 & 3 & $\mathrm{~S}$ & $R$ & 13,218 & 8,407 \\
\hline 2,164 & 300 & 90 & 0.4 & 240 & $A$ & & 3 & 1 & $\bar{D}$ & 9,725 & 10,795 \\
\hline 2,165 & 300 & 90 & 0.4 & 480 & A & & 3 & I & D & 9,087 & 10,087 \\
\hline 2,166 & 300 & 90 & 0.4 & 240 & $\bar{A}$ & & 3 & I & $\bar{D}$ & 10,520 & 11,677 \\
\hline 2,167 & 300 & 90 & 0.4 & 480 & A & & 3 & 1 & D & 9,882 & 10,969 \\
\hline 2,168 & 300 & 90 & 0.4 & 240 & A & 16 & 3 & I & $R$ & 14,482 & 9,211 \\
\hline 2,169 & 300 & 90 & 0.4 & 240 & A & 16 & 3 & $S$ & $\mathbf{R}$ & 13,750 & 8,745 \\
\hline 2,170 & 300 & 108 & 0.4 & 240 & A & 16 & 3 & $I$ & $R$ & 15,546 & 9,887 \\
\hline 2,171 & 300 & 108 & 0.4 & 240 & A & 16 & 3 & $S$ & $R$ & 14,631 & 9,305 \\
\hline 2,172 & 300 & 144 & 0.4 & 240 & $\bar{A}$ & 16 & 3 & $T$ & $\mathbf{R}$ & 15,957 & 10,149 \\
\hline 2,173 & 300 & 144 & 0.4 & 240 & A & 16 & 3 & $S$ & $\mathbf{R}$ & 15,163 & 9,644 \\
\hline 2,174 & 300 & 150 & 0.4 & 240 & $\bar{A}$ & & 3 & 1 & D & 11,516 & 12,783 \\
\hline 2,175 & 300 & 150 & 0.4 & 480 & $A$ & & 3 & $\mathrm{I}$ & $D$ & 10,535 & 11,694 \\
\hline 2,176 & 300 & 150 & 0.4 & 240 & $\bar{A}$ & & 3 & $\mathrm{I}$ & D & 12,311 & 13,665 \\
\hline 2,177 & 300 & 150 & 0.4 & 480 & A & & 3 & 1 & D & 11,330 & 12,576 \\
\hline 2,178 & 300 & 210 & 0.4 & 240 & $A$ & & 3 & 1 & D & 13,457 & 14,937 \\
\hline 2,179 & 300 & 210 & 0.4 & 480 & A & & 3 & 1 & $\bar{D}$ & 11,833 & 13,135 \\
\hline 2,180 & 300 & 210 & 0.4 & 240 & $A$ & & 3 & I & D & 14,252 & 15,820 \\
\hline 2,181 & 300 & 210 & 0.4 & 480 & A & & 3 & $T$ & $\bar{D}$ & 12,628 & 14,017 \\
\hline 2,182 & 300 & 240 & 0.4 & 240 & A & & 3 & 1 & D & 14,331 & 15,907 \\
\hline 2,183 & 300 & 240 & 0.4 & 480 & $\bar{A}$ & & 3 & I & D & 12,522 & 13,899 \\
\hline 2,184 & 300 & 240 & 0.4 & 240 & A & & 3 & 1 & D & 15,126 & 16,790 \\
\hline 2,185 & 300 & 240 & 0.4 & 480 & $\bar{A}$ & & 3 & 1 & D & 13,317 & 14,782 \\
\hline 2,186 & 300 & 300 & 0.4 & 240 & $A$ & & 3 & 1 & D & 16,050 & 17,816 \\
\hline 2,187 & 300 & 300 & 0.4 & 480 & A & & 3 & 1 & $D$ & 14,000 & 15,540 \\
\hline 2,188 & 300 & 300 & 0.4 & 240 & A & & 3 & 1 & D & 16,845 & 18,698 \\
\hline 2,189 & 300 & 300 & 0.4 & 480 & $A$ & & 3 & 1 & D & 14,795 & 16,422 \\
\hline 2,190 & 350 & 60 & 0.4 & 240 & A & & 3 & $T$ & $D$ & 9,022 & 10,014 \\
\hline 2,191 & 350 & 60 & 0.4 & 480 & $A$ & & 3 & 1 & $\mathrm{D}$ & 8,627 & 9,576 \\
\hline 2,192 & 350 & 60 & 0.4 & 240 & A & & 3 & 1 & D & 9,817 & 10,897 \\
\hline 2,193 & 350 & 60 & 0.4 & 480 & A & & 3 & 1 & D & 9,422 & 10,458 \\
\hline 2,194 & 350 & 90 & 0.4 & 240 & $\bar{A}$ & & 3 & 1 & D & 10,047 & 11,152 \\
\hline 2,195 & 350 & 90 & 0.4 & 480 & A & & 3 & 1 & $D$ & 9,409 & 10,444 \\
\hline 2,196 & 350 & 90 & 0.4 & 240 & $A$ & & 3 & $I$ & D & 10,842 & 12,035 \\
\hline 2,197 & 350 & 90 & 0.4 & 480 & A & & 3 & I & D & 10,204 & 11,326 \\
\hline 2,198 & 350 & 120 & 0.4 & 240 & $A$ & & 3 & 1 & D & 11,021 & 12,233 \\
\hline 2,199 & 350 & 120 & 0.4 & 480 & A & & 3 & 1 & D & 10,170 & 11,289 \\
\hline 2,200 & 350 & 120 & 0.4 & 240 & A & & 3 & 1 & $\bar{D}$ & 11,816 & 13,116 \\
\hline 2,201 & 350 & 120 & 0.4 & 480 & A & & 3 & 1 & D & 10,965 & 12,171 \\
\hline 2,202 & 350 & 180 & 0.4 & 240 & A & & 3 & 1 & D & 12,524 & 13,902 \\
\hline 2,203 & 350 & 180 & 0.4 & 480 & A & & 3 & 1 & $\mathrm{D}$ & 11,448 & 12,707 \\
\hline 2,204 & 350 & 180 & 0.4 & 240 & A & & 3 & 1 & $D$ & 13,319 & 14,784 \\
\hline 2,205 & 350 & 180 & 0.4 & 480 & A & & 3 & 1 & $D$ & 12,243 & 13,590 \\
\hline 2,206 & 350 & 240 & 0.4 & 240 & A & & 3 & 1 & D & 14,654 & 16,266 \\
\hline
\end{tabular}


Table A.3. Electric Storage Water Heaters (contd)

\begin{tabular}{|c|c|c|c|c|c|c|c|c|c|c|c|}
\hline REC & VOL & INP & STBY & VOLT & TANK & RVAL & WARR & THERM & CTYPE & LCOST & CCOST \\
\hline 2,207 & 350 & 240 & 0.4 & 480 & A & & 3 & 1 & $\mathrm{D}$ & 12,835 & 14,247 \\
\hline 2,208 & 350 & 240 & 0.4 & 240 & A & & 3 & 1 & D & 15,449 & 17,148 \\
\hline 2,209 & 350 & 240 & 0.4 & 480 & $\bar{A}$ & & 3 & 1 & D & 13,630 & 15,129 \\
\hline 2,210 & 350 & 300 & 0.4 & 240 & $A$ & & 3 & 1 & D & 17,154 & 19,041 \\
\hline 2,211 & 350 & 300 & 0.4 & 480 & $\bar{A}$ & & 3 & I & D & 14,327 & 15,903 \\
\hline 2,212 & 350 & 300 & 0.4 & 240 & A & & 3 & 1 & D & 17,949 & 19,923 \\
\hline 2,213 & 350 & 300 & 0.4 & 480 & A & & 3 & 1 & $D$ & 15,122 & 16,785 \\
\hline 2,214 & 400 & 15 & 0.4 & 240 & $A$ & 16 & 3 & 1 & $\mathbf{R}$ & 13,207 & 8,400 \\
\hline 2,215 & 400 & 15 & 0.4 & 240 & A & 16 & 3 & $S$ & $\mathbf{R}$ & 14,994 & 9,536 \\
\hline 2,216 & 400 & 18 & 0.4 & 240 & $\bar{A}$ & 16 & 3 & 1 & $\mathbf{R}$ & 14,094 & 8,964 \\
\hline 2,217 & 400 & 18 & 0.4 & 240 & A & 16 & 3 & $S$ & $\mathbf{R}$ & 13,232 & 8,416 \\
\hline 2,218 & 400 & 30 & 0.4 & 240 & A & 16 & 3 & 1 & $\mathbf{R}$ & 14,200 & 9,031 \\
\hline 2,219 & 400 & 30 & 0.4 & 240 & A & 16 & 3 & $S$ & $\mathbf{R}$ & 13,487 & 8,578 \\
\hline 2,220 & 400 & 36 & 0.4 & 240 & A & 16 & 3 & 1 & $\mathrm{R}$ & 14,237 & 9,055 \\
\hline 2,221 & 400 & 36 & 0.4 & 240 & $A$ & 16 & 3 & $S$ & $\mathrm{R}$ & 13,525 & 8,602 \\
\hline 2,222 & 400 & 45 & 0.4 & 240 & A & 16 & 3 & 1 & $\mathrm{R}$ & 14,294 & 9,091 \\
\hline 2,223 & 400 & 45 & 0.4 & 240 & A & 16 & 3 & $S$ & $R$ & 13,582 & 8,638 \\
\hline 2,224 & 400 & 54 & 0.4 & 240 & A & 16 & 3 & 1 & $R$ & 15,032 & 9,560 \\
\hline 2,225 & 400 & 54 & 0.4 & 240 & $\bar{A}$ & 16 & 3 & $S$ & $\bar{R}$ & 14,294 & 9,091 \\
\hline 2,226 & 400 & 72 & 0.4 & 240 & $\bar{A}$ & 16 & 3 & 1 & $\bar{R}$ & 15,994 & 10,172 \\
\hline 2,227 & 400 & 72 & 0.4 & 240 & A & 16 & 3 & $S$ & $R$ & 15,200 & 9,667 \\
\hline 2,228 & 400 & 75 & 0.4 & 240 & $\bar{A}$ & & 3 & 1 & D & 10,746 & 11,928 \\
\hline 2,229 & 400 & 75 & 0.4 & 480 & A & & 3 & 1 & D & 10,243 & 11,370 \\
\hline 2,230 & 400 & 75 & 0.4 & 240 & A & & 3 & $T$ & $D$ & 11,541 & 12,811 \\
\hline 2,231 & 400 & 75 & 0.4 & 480 & A & & 3 & 1 & D & 11,038 & 12,252 \\
\hline 2,232 & 400 & 90 & 0.4 & 240 & $\bar{A}$ & 16 & 3 & 1 & $\mathbf{R}$ & 16,520 & 10,507 \\
\hline 2,233 & 400 & 90 & 0.4 & 240 & $\bar{A}$ & 16 & 3 & 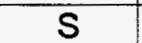 & $R$ & 15,694 & 9,981 \\
\hline 2,234 & 400 & 108 & 0.4 & 240 & A & 16 & 3 & 1 & $\mathrm{R}$ & 17,445 & 11,095 \\
\hline 2,235 & 400 & 108 & 0.4 & 240 & $\mathrm{~A}$ & 16 & 3 & $S$ & $\mathrm{R}$ & 16,583 & 10,547 \\
\hline 2,236 & 400 & 120 & 0.4 & 240 & A & & 3 & 1 & D & 12,101 & 13,432 \\
\hline 2,237 & 400 & 120 & 0.4 & 480 & A & & 3 & 1 & $\bar{D}$ & 11,273 & 12,513 \\
\hline 2,238 & 400 & 120 & 0.4 & 240 & A & & 3 & 1 & $D$ & 12,896 & 14,315 \\
\hline 2,239 & 400 & 120 & 0.4 & 480 & $A$ & & 3 & 1 & D & 12,068 & 13,395 \\
\hline 2,240 & 400 & 144 & 0.4 & 240 & A & 16 & 3 & 1 & $\mathrm{R}$ & 18,038 & 11,472 \\
\hline 2,241 & 400 & 144 & 0.4 & 240 & A & 16 & 3 & $S$ & $R$ & 17,147 & 10,905 \\
\hline 2,242 & 400 & 210 & 0.4 & 240 & A & & 3 & $T$ & D & 14,964 & 16,610 \\
\hline 2,243 & 400 & 210 & 0.4 & 480 & A & & 3 & 1 & D & 13,237 & 14,693 \\
\hline 2,244 & 400 & 210 & 0.4 & 240 & A & & 3 & 1 & $D$ & 15,759 & 17,492 \\
\hline 2,245 & 400 & 210 & 0.4 & 480 & A & & 3 & 1 & D & 14,032 & 15,576 \\
\hline 2,246 & 400 & 300 & 0.4 & 240 & A & & 3 & I & D & 17,243 & 19,140 \\
\hline 2,247 & 400 & 300 & 0.4 & 480 & $\bar{A}$ & & 3 & 1 & D & 15,775 & 17,510 \\
\hline 2,248 & 400 & 300 & 0.4 & 240 & A & & 3 & I & D & 18,038 & 20,022 \\
\hline 2,249 & 400 & 300 & 0.4 & 480 & A & & 3 & 1 & D & 16,570 & 18,393 \\
\hline 2,250 & 400 & 330 & 0.4 & 240 & A & & 3 & $\mathrm{~T}$ & D & 18,298 & 20,311 \\
\hline 2,251 & 400 & 330 & 0.4 & 480 & A & & 3 & 1 & $D$ & 15,909 & 17,659 \\
\hline
\end{tabular}


Table A.3. Electric Storage Water Heaters (contd)

\begin{tabular}{|c|c|c|c|c|c|c|c|c|c|c|c|}
\hline REC & VOL & INP & STBY & VOLT & TANK & RVAL & WARR & THERM & CTYPE & LCOST & CCOST \\
\hline 2,252 & 400 & 330 & 0.4 & 240 & $A$ & & 3 & 1 & D & 19,093 & 21,193 \\
\hline 2,253 & 400 & 330 & 0.4 & 480 & $A$ & & 3 & 1 & D & 16,704 & 18,541 \\
\hline 2,254 & 400 & 390 & 0.4 & 240 & $A$ & & 3 & 1 & $D$ & 20,406 & 22,651 \\
\hline 2,255 & 400 & 390 & 0.4 & 480 & $A$ & & 3 & I & D & 17,472 & 19,394 \\
\hline 2,256 & 400 & 390 & 0.4 & 240 & A & & 3 & I & $\mathrm{D}$ & 21,201 & 23,533 \\
\hline 2,257 & 400 & 390 & 0.4 & 480 & $\bar{A}$ & & 3 & 1 & $\bar{D}$ & 18,267 & 20,276 \\
\hline 2,258 & 500 & 15 & 0.3 & 240 & $\bar{A}$ & 16 & 3 & 1 & $\mathbf{R}$ & 16,207 & 10,308 \\
\hline 2,259 & 500 & 15 & 0.3 & 240 & $A$ & 16 & 3 & 5 & $R$ & 16,857 & 10,721 \\
\hline 2,260 & 500 & 18 & 0.3 & 240 & A & 16 & 3 & 1 & $\mathbf{R}$ & 16,233 & 10,324 \\
\hline 2,261 & 500 & 18 & 0.3 & 240 & A & 16 & 3 & $S$ & $\mathbf{R}$ & 15,419 & 9,806 \\
\hline 2,262 & 500 & 30 & 0.3 & 240 & A & 16 & 3 & 1 & $\mathbf{R}$ & 16,357 & 10,403 \\
\hline 2,263 & 500 & 30 & 0.3 & 240 & A & 16 & 3 & $S$ & $\mathbf{R}$ & 15,531 & 9,878 \\
\hline 2,264 & 500 & 36 & 0.3 & 240 & $A$ & 16 & 3 & 1 & $\mathbf{R}$ & 16,809 & 10,691 \\
\hline 2,265 & 500 & 36 & 0.3 & 240 & A & 16 & 3 & S & $R$ & 15,606 & 9,925 \\
\hline 2,266 & 500 & 45 & 0.3 & 240 & A & 16 & 3 & 1 & $R$ & 16,464 & 10,471 \\
\hline 2,267 & 500 & 45 & 0.3 & 240 & A & 16 & 3 & $S$ & $R$ & 15,651 & 9,954 \\
\hline 2,268 & 500 & 54 & 0.3 & 240 & A & 16 & 3 & 1 & $\mathrm{R}$ & 17,083 & 10,865 \\
\hline 2,269 & 500 & 54 & 0.3 & 240 & A & 16 & 3 & $S$ & $\mathbf{R}$ & 16,219 & 10,315 \\
\hline 2,270 & 500 & 72 & 0.3 & 240 & A & 16 & 3 & 1 & $\mathrm{R}$ & 18,008 & 11,453 \\
\hline 2,271 & 500 & 72 & 0.3 & 240 & A & 16 & 3 & $S$ & $\mathbf{R}$ & 17,107 & 10,880 \\
\hline 2,272 & 500 & 75 & 0.4 & 240 & A & & 3 & 1 & $D$ & 12,016 & 13,338 \\
\hline 2,273 & 500 & 75 & 0.4 & 480 & A & & 3 & 1 & D & 11,531 & 12,799 \\
\hline 2,274 & 500 & 75 & 0.4 & 240 & A & & 3 & 1 & D & 12,811 & 14,220 \\
\hline 2,275 & 500 & 75 & 0.4 & 480 & A & & 3 & 1 & D & 12,326 & 13,682 \\
\hline 2,276 & 500 & 90 & 0.3 & 240 & A & 16 & 3 & 1 & $R$ & 18,557 & 11,802 \\
\hline 2,277 & 500 & 90 & 0.3 & 240 & A & 16 & 3 & $S$ & $\mathrm{R}$ & 17,936 & 11,407 \\
\hline 2,278 & 500 & 108 & 0.3 & 240 & A & 16 & 3 & 1 & $\mathbf{R}$ & 19,871 & 12,638 \\
\hline 2,279 & 500 & 108 & 0.3 & 240 & A & 16 & 3 & $S$ & $\mathbf{R}$ & 18,871 & 12,002 \\
\hline 2,280 & 500 & 120 & 0.4 & 240 & A & & 3 & 1 & $D$ & 13,537 & 15,026 \\
\hline 2,281 & 500 & 120 & 0.4 & 480 & $A$ & & 3 & 1 & $D$ & 12,785 & 14,191 \\
\hline 2,282 & 500 & 120 & 0.4 & 240 & A & & 3 & 1 & $D$ & 14,332 & 15,909 \\
\hline 2,283 & 500 & 120 & 0.4 & 480 & A & & 3 & 1 & $\bar{D}$ & 13,580 & 15,074 \\
\hline 2,284 & 500 & 144 & 0.3 & 240 & A & 16 & 3 & 1 & $\mathrm{R}$ & 20,234 & 12,869 \\
\hline 2,285 & 500 & 144 & 0.3 & 240 & A & 16 & 3 & $S$ & $R$ & 19,221 & 12,225 \\
\hline 2,286 & 500 & 210 & 0.4 & 240 & $A$ & & 3 & 1 & $\mathrm{D}$ & 16,567 & 18,389 \\
\hline 2,287 & 500 & 210 & 0.4 & 480 & A & & 3 & 1 & $\bar{D}$ & 14,976 & 16,623 \\
\hline 2,288 & 500 & 210 & 0.4 & 240 & A & & 3 & 1 & D & 17,362 & 19,272 \\
\hline 2,289 & 500 & 210 & 0.4 & 480 & A & & 3 & $\mathrm{I}$ & $\mathrm{D}$ & 15,771 & 17,506 \\
\hline 2,290 & 500 & 300 & 0.4 & 240 & A & & 3 & 1 & D & 19,370 & 21,501 \\
\hline 2,291 & 500 & 300 & 0.4 & 480 & A & & 3 & 1 & $\mathrm{D}$ & 17,398 & 19,312 \\
\hline 2,292 & 500 & 300 & 0.4 & 240 & $\bar{A}$ & & 3 & 1 & $\mathrm{D}$ & 20,165 & 22,383 \\
\hline 2,293 & 500 & 300 & 0.4 & 480 & A & & 3 & 1 & D & 18,193 & 20,194 \\
\hline 2,294 & 500 & 390 & 0.4 & 240 & $\mathrm{~A}$ & & 3 & 1 & $D$ & 22,575 & 25,058 \\
\hline 2,295 & 500 & 390 & 0.4 & 480 & A & & 3 & 1 & $D$ & 19,718 & 21,887 \\
\hline 2,296 & 500 & 390 & 0.4 & 240 & A & & 3 & 1 & $D$ & 23,370 & 25,941 \\
\hline
\end{tabular}


Table A.3. Electric Storage Water Heaters (contd)

\begin{tabular}{|c|c|c|c|c|c|c|c|c|c|c|c|}
\hline REC & VOL & $\overline{I N P}$ & STBY & VOLT & TANK & RVAL & WARR & THERM & CTYPE & LCOST & CCOST \\
\hline 2,297 & 500 & 390 & 0.4 & 480 & $A$ & & 3 & 1 & D & 20,513 & 22,769 \\
\hline 2,298 & 500 & 480 & 0.4 & 240 & $A$ & & 3 & $T$ & $\bar{D}$ & 25,025 & 27,778 \\
\hline 2,299 & 500 & 480 & 0.4 & 480 & $A$ & & 3 & 1 & D & 21,867 & 24,272 \\
\hline 2,300 & 500 & 480 & 0.4 & 240 & $A$ & & 3 & I & D & 25,820 & 28,660 \\
\hline 2,301 & 500 & 480 & 0.4 & 480 & $\bar{A}$ & & 3 & $\mathrm{I}$ & D & 22,662 & 25,155 \\
\hline 2,302 & 600 & 15 & 0.3 & 240 & $\bar{A}$ & 16 & 3 & I & $\mathbf{R}$ & 17,845 & 11,349 \\
\hline 2,303 & 600 & 15 & 0.3 & 240 & $\bar{A}$ & 16 & 3 & $S$ & $\mathbf{R}$ & 16,857 & 10,721 \\
\hline 2,304 & 600 & 18 & 0.3 & 240 & A & 16 & 3 & 1 & $R$ & 18,946 & 12,050 \\
\hline 2,305 & 600 & 18 & 0.3 & 240 & A & 16 & 3 & $S$ & $R$ & 17,983 & 11,437 \\
\hline 2,306 & 600 & 30 & 0.3 & 240 & A & 16 & 3 & 1 & $\mathrm{R}$ & 18,971 & 12,066 \\
\hline 2,307 & 600 & 30 & 0.3 & 240 & $\bar{A}$ & 16 & 3 & $S$ & $\mathbf{R}$ & 18,021 & 11,461 \\
\hline 2,308 & 600 & 36 & 0.3 & 240 & A & 16 & 3 & 1 & $\mathbf{R}$ & 19,009 & 12,090 \\
\hline 2,309 & 600 & 36 & 0.3 & 240 & A & 16 & 3 & $S$ & $R$ & 18,057 & 11,484 \\
\hline 2,310 & 600 & 45 & 0.3 & 240 & $\bar{A}$ & 16 & 3 & 1 & $\mathbf{R}$ & 19,046 & 12,113 \\
\hline 2,311 & 600 & 45 & 0.3 & 240 & $A$ & 16 & 3 & $S$ & $R$ & 18,096 & 11,509 \\
\hline 2,312 & 600 & 54 & 0.3 & 240 & A & 16 & 3 & 1 & $\mathrm{R}$ & 19,084 & 12,137 \\
\hline 2,313 & 600 & 54 & 0.3 & 240 & A & 16 & 3 & $S$ & $\mathrm{R}$ & 18,132 & 11,532 \\
\hline 2,314 & 600 & 72 & 0.3 & 240 & A & 16 & 3 & 1 & $R$ & 19,859 & 12,630 \\
\hline 2,315 & 600 & 72 & 0.3 & 240 & $\bar{A}$ & 16 & 3 & $S$ & $R$ & 18,869 & 12,001 \\
\hline 2,316 & 600 & 90 & 0.3 & 240 & A & 16 & 3 & 1 & $\mathrm{R}$ & 20,609 & 13,107 \\
\hline 2,317 & 600 & 90 & 0.3 & 240 & A & 16 & 3 & $S$ & $R$ & 19,571 & 12,447 \\
\hline 2,318 & 600 & 108 & 0.3 & 240 & $\bar{A}$ & 16 & 3 & 1 & R & 21,710 & 13,808 \\
\hline 2,319 & 600 & 108 & 0.3 & 240 & $A$ & 16 & 3 & $S$ & $R$ & 20,634 & 13,123 \\
\hline 2,320 & 600 & 144 & 0.3 & 240 & A & 16 & 3 & 1 & $R$ & 22,091 & 14,050 \\
\hline 2,321 & 600 & 144 & 0.3 & 240 & A & 16 & 3 & S & $R$ & 20,984 & 13,346 \\
\hline 2,322 & 700 & 15 & 0.3 & 240 & $A$ & 16 & 3 & 1 & $\mathrm{R}$ & 19,946 & 12,686 \\
\hline 2,323 & 700 & 15 & 0.3 & 240 & $A$ & 16 & 3 & $\mathrm{~S}$ & $\mathbf{R}$ & 18,871 & 12,002 \\
\hline 2,324 & 700 & 18 & 0.3 & 240 & $A$ & 16 & 3 & $\mathrm{I}$ & $\bar{R}$ & 19,960 & 12,695 \\
\hline 2,325 & 700 & 18 & 0.3 & 240 & A & 16 & 3 & S & $R$ & 18,908 & 12,025 \\
\hline 2,326 & 700 & 30 & 0.3 & 240 & A & 16 & 3 & 1 & $R$ & 19,970 & 12,701 \\
\hline 2,327 & 700 & 30 & 0.3 & 240 & $A$ & 16 & 3 & $S$ & $R$ & 18,946 & 12,050 \\
\hline 2,328 & 700 & 36 & 0.3 & 240 & $A$ & 16 & 3 & 1 & $\mathbf{R}$ & 19,871 & 12,638 \\
\hline 2,329 & 700 & 36 & 0.3 & 240 & $A$ & 16 & 3 & $S$ & $\mathbf{R}$ & 18,958 & 12,057 \\
\hline 2,330 & 700 & 45 & 0.3 & 240 & $\bar{A}$ & 16 & 3 & 1 & $\bar{R}$ & 19,896 & 12,654 \\
\hline 2,331 & 700 & 45 & 0.3 & 240 & A & 16 & 3 & $\mathrm{~S}$ & $\mathrm{R}$ & 18,976 & 12,069 \\
\hline 2,332 & 700 & 54 & 0.3 & 240 & A & 16 & 3 & 1 & $R$ & 20,047 & 12,750 \\
\hline 2,333 & 700 & 54 & 0.3 & 240 & A & 16 & 3 & $\mathrm{~S}$ & $\mathrm{R}$ & 19,046 & $.12,113$ \\
\hline 2,334 & 700 & 72 & 0.3 & 240 & $A$ & 16 & 3 & 1 & $\mathbf{R}$ & 20,972 & 13,338 \\
\hline 2,335 & 700 & 72 & 0.3 & 240 & A & 16 & 3 & S & $R$. & 19,928 & 12,674 \\
\hline 2,336 & 700 & 90 & 0.3 & 240 & A & 16 & 3 & 1 & $R$ & 21,434 & 13,632 \\
\hline 2,337 & 700 & 90 & 0.3 & 240 & A & 16 & 3 & $S$ & $R$ & 20,365 & 12,952 \\
\hline 2,338 & 700 & 108 & 0.3 & 240 & A & 16 & 3 & 1 & $\mathrm{R}$ & 21,910 & 13,935 \\
\hline 2,339 & 700 & 108 & 0.3 & 240 & $A$ & 16 & 3 & S & $R$ & 20,816 & 13,239 \\
\hline 2,340 & 700 & 144 & 0.3 & 240 & A & 16 & 3 & 1 & $\mathrm{R}$ & 23,211 & 14,762 \\
\hline 2,341 & 700 & 144 & 0.3 & 240 & A & 16 & 3 & $\mathrm{~S}$ & $R$ & 22,035 & 14,014 \\
\hline
\end{tabular}


Table A.3. Electric Storage Water Heaters (contd)

\begin{tabular}{|c|c|c|c|c|c|c|c|c|c|c|c|}
\hline REC & VOL & INP & STBY & VOLT & TANK & RVAL & WARR & THERM & CTYPE & LCOST & CCOST \\
\hline 2,342 & 800 & 15 & 0.3 & 240 & A & 16 & 3 & 1 & $R$ & 21,559 & 13,712 \\
\hline 2,343 & 800 & 15 & 0.3 & 240 & A & 16 & 3 & S & $\mathrm{R}$ & 19,716 & 12,539 \\
\hline 2,344 & 800 & 18 & 0.3 & 240 & A & 16 & 3 & 1 & $R$ & 21,586 & 13,729 \\
\hline 2,345 & 800 & 18 & 0.3 & 240 & $\bar{A}$ & 16 & 3 & $S$ & $R$ & 20,504 & 13,041 \\
\hline 2,346 & 800 & 30 & 0.3 & 240 & $A$ & 16 & 3 & 1 & $\mathbf{R}$ & 21,604 & 13,740 \\
\hline 2,347 & 800 & 30 & 0.3 & 240 & A & 16 & 3 & $\mathrm{~s}$ & $R$ & 20,523 & 13,053 \\
\hline 2,348 & 800 & 36 & 0.3 & 240 & $\mathrm{~A}$ & 16 & 3 & 1 & $R$ & 21,660 & 13,776 \\
\hline 2,349 & 800 & 36 & 0.3 & 240 & $A$ & 16 & 3 & $S$ & $R$ & 20,572 & 13,084 \\
\hline 2,350 & 800 & 45 & 0.3 & 240 & $A$ & 16 & 3 & 1 & $R$ & 21,710 & 13,808 \\
\hline 2,351 & 800 & 45 & 0.3 & 240 & $\bar{A}$ & 16 & 3 & $S$ & $R$ & 20,628 & 13,119 \\
\hline 2,352 & 800 & 54 & 0.3 & 240 & A & 16 & 3 & 1 & $R$ & 22,135 & 14,078 \\
\hline 2,353 & 800 & 54 & 0.3 & 240 & $\bar{A}$ & 16 & 3 & $S$ & $R$ & 21,023 & 13,371 \\
\hline 2,354 & 800 & 72 & 0.3 & 240 & $\bar{A}$ & 16 & 3 & 1 & $\mathrm{R}$ & 22,197 & 14,117 \\
\hline 2,355 & 800 & 72 & 0.3 & 240 & A & 16 & 3 & $S$ & $R$ & 21,091 & 13,414 \\
\hline 2,356 & 800 & 90 & 0.3 & 240 & $A$ & 16 & 3 & 1 & $R$ & 22,411 & 14,253 \\
\hline 2,357 & 800 & 90 & 0.3 & 240 & $\bar{A}$ & 16 & 3 & $S$ & $R$ & 21,290 & 13,540 \\
\hline 2,358 & 800 & 108 & 0.3 & 240 & $\bar{A}$ & 16 & 3 & 1 & $R$ & 23,161 & 14,730 \\
\hline 2,359 & 800 & 108 & 0.3 & 240 & A & 16 & 3 & S & $\mathrm{R}$ & 21,991 & 13,986 \\
\hline 2,360 & 800 & 144 & 0.3 & 240 & $\bar{A}$ & 16 & 3 & 1 & $R$ & 24,299 & 15,454 \\
\hline 2,361 & 800 & 144 & 0.3 & 240 & $\bar{A}$ & 16 & 3 & $S$ & $R$ & 23,086 & 14,683 \\
\hline 2,362 & 1,000 & 15 & 0.3 & 240 & $\bar{A}$ & 16 & 3 & 1 & $\mathrm{R}$ & 23,622 & 15,024 \\
\hline 2,363 & 1,000 & 15 & 0.3 & 240 & A & 16 & 3 & $S$ & $\bar{R}$ & 22,366 & 14,225 \\
\hline 2,364 & 1,000 & 18 & 0.3 & 240 & A & 16 & 3 & $i$ & $R$ & 23,586 & 15,001 \\
\hline 2,365 & 1,000 & 18 & 0.3 & 240 & $\mathrm{~A}$ & 16 & 3 & $S$ & $R$ & 22,411 & 14,253 \\
\hline 2,366 & 1,000 & 30 & 0.3 & 240 & A & 16 & 3 & 1 & $R$ & 23,617 & 15,020 \\
\hline 2,367 & 1,000 & 30 & 0.3 & 240 & A & 16 & 3 & $S$ & $R$ & 22,435 & 14,269 \\
\hline 2,368 & 1,000 & 36 & 0.3 & 240 & $\bar{A}$ & 16 & 3 & 1 & $R$ & 23,649 & 15,041 \\
\hline 2,369 & 1,000 & 36 & 0.3 & 240 & A & 16 & 3 & $S$ & $R$ & 22,467 & 14,289 \\
\hline 2,370 & 1,000 & 45 & 0.3 & 240 & A & 16 & 3 & 1 & $R$ & 23,723 & 15,088 \\
\hline 2,371 & 1,000 & 45 & 0.3 & 240 & A & 16 & 3 & $S$ & $R$ & 22,535 & 14,332 \\
\hline 2,372 & 1,000 & 54 & 0.3 & 240 & A & 16 & 3 & 1 & $R$ & 23,747 & 15,103 \\
\hline 2,373 & 1,000 & 54 & 0.3 & 240 & A & 16 & 3 & $\bar{s}$ & $R$ & 22,573 & 14,356 \\
\hline 2,374 & 1,000 & 72 & 0.3 & 240 & $A$ & 16 & 3 & 1 & $R$ & 23,854 & 15,171 \\
\hline 2,375 & 1,000 & 72 & 0.3 & 240 & $\bar{A}$ & 16 & 3 & $S$ & R & 22,660 & 14,412 \\
\hline 2,376 & 1,000 & 90 & 0.3 & 240 & A & 16 & 3 & 1 & $\mathrm{R}$ & 23,949 & 15,232 \\
\hline 2,377 & 1,000 & 90 & 0.3 & 240 & $\bar{A}$ & 16 & 3 & $S$ & $R$ & 22,741 & 14,463 \\
\hline 2,378 & 1,000 & 108 & 0.3 & 240 & A & 16 & 3 & 1 & $R$. & 24,498 & 15,581 \\
\hline 2,379 & 1,000 & 108 & 0.3 & 240 & A & 16 & 3 & $S$ & R & 23,273 & 14,802 \\
\hline 2,380 & 1,000 & 144 & 0.3 & 240 & A & 16 & 3 & 1 & D & 25,631 & 16,301 \\
\hline 2,381 & 1,000 & 144 & 0.3 & 240 & $\mathrm{~A}$ & 16 & 3 & $S$ & $R$ & 23,585 & 15,000 \\
\hline
\end{tabular}


Table A.4. Unfired Hot Water Storage Tanks

\begin{tabular}{|c|c|c|c|c|c|c|c|c|c|c|}
\hline REC & $\mathrm{VOL}$ & RVAL & TANK & LIN & ORIENT & PRESS & WARR & CTYPE & LCOST & CCOST \\
\hline 2,382 & 40 & & $S$ & $s$ & $V$ & 150 & 10 & $D$ & 235 & 282 \\
\hline 2,383 & 40 & 16 & $S$ & $S$ & $\bar{V}$ & 150 & 10 & $\bar{D}$ & 272 & 326 \\
\hline 2,384 & 40 & & $S$ & $\bar{s}$ & $\mathrm{~V}$ & & 5 & $\bar{R}$ & 576 & 490 \\
\hline 2,385 & 80 & 16 & $S$ & $\bar{G}$ & $\bar{V}$ & 150 & 5 & $R$ & 654 & 432 \\
\hline 2,386 & 80 & & $\bar{A}$ & $\mathbf{G}$ & $\bar{V}$ & 160 & 5 & $\bar{D}$ & 992 & 1,091 \\
\hline 2,387 & 80 & 13 & $A$ & $\mathbf{G}$ & $\bar{V}$ & 125 & 5 & $\bar{D}$ & 990 & 1,089 \\
\hline 2,388 & 80 & 16 & $\bar{A}$ & $\bar{E}$ & $\bar{V}$ & 160 & 5 & $\bar{R}$ & 1,100 & 605 \\
\hline 2,389 & 80 & & $S$ & $\bar{S}$ & $\mathrm{~V}$ & 150 & 10 & D & 345 & 414 \\
\hline 2,390 & 80 & 16 & $S$ & $s$ & $\mathrm{~V}$ & 150 & 10 & $\bar{D}$ & 380 & 456 \\
\hline 2,391 & 80 & 16 & $S$ & $\bar{G}$ & $\mathrm{~V}$ & & 5 & $D$ & 524 & 576 \\
\hline 2,392 & 80 & & $S$ & $\bar{G}$ & $\bar{V}$ & 160 & 5 & $\bar{D}$ & 550 & 605 \\
\hline 2,393 & 80 & & S & $\bar{s}$ & $\bar{V}$ & & 5 & $\bar{R}$ & 873 & 742 \\
\hline 2,394 & 80 & & $S$ & $\bar{G}$ & $\mathrm{~V}$ & 150 & 5 & D & 550 & 605 \\
\hline 2,395 & 90 & 16 & $\mathbf{S}$ & $\bar{G}$ & V & 150 & 5 & $R$ & 962 & 635 \\
\hline 2,396 & 120 & 16 & $\bar{A}$ & $\bar{E}$ & $\bar{V}$ & 160 & 5 & $\bar{R}$ & 2,300 & 1,265 \\
\hline 2,397 & 120 & 16 & $\bar{A}$ & G & $\bar{V}$ & 150 & 5 & $\overline{\mathbf{R}}$ & 1,881 & 1,241 \\
\hline 2,398 & 120 & 16 & $S$ & $G$ & $\bar{V}$ & & 5 & $\bar{D}$ & 604 & 664 \\
\hline 2,399 & 120 & 16 & $\mathrm{~s}$ & $\mathbf{G}$ & $\bar{V}$ & 150 & 5 & $\bar{R}$ & 962 & 635 \\
\hline 2,400 & 120 & 16 & $s$ & $\mathbf{G}$ & $\bar{V}$ & 150 & 5 & $R$ & 2,116 & 1,397 \\
\hline 2,401 & 120 & 16 & $\bar{A}$ & $G$ & $\bar{V}$ & & 5 & $\bar{D}$ & 1,339 & 1,473 \\
\hline 2,402 & 120 & & A & G & $\bar{V}$ & 160 & 5 & $\bar{D}$ & 1,036 & 1,140 \\
\hline 2,403 & 120 & 13 & $\bar{A}$ & $\bar{G}$ & $\bar{V}$ & 125 & 5 & $\bar{D}$ & 1,165 & 1,282 \\
\hline 2,404 & 120 & & $\mathrm{~S}$ & $S$ & V & 150 & 5 & $\bar{D}$ & 462 & 554 \\
\hline 2,405 & 120 & 16 & $\mathrm{~S}$ & $\mathrm{~S}$ & V & 150 & 5 & D & 516 & 619 \\
\hline 2,406 & 120 & & $\bar{S}$ & $G$ & $\bar{V}$ & 160 & 5 & $\bar{D}$ & 565 & 622 \\
\hline 2,407 & 120 & & $s$ & $S$ & V & & 5 & $R$ & 1,100 & 935 \\
\hline 2,408 & 120 & & $\mathrm{~s}$ & G & $\bar{V}$ & 150 & 5 & D & 571 & 628 \\
\hline 2,409 & 140 & 13 & $\bar{A}$ & $\bar{G}$ & $\bar{V}$ & 125 & 5 & D & 1,637 & 1,801 \\
\hline 2,410 & 180 & & A & G & $\bar{V}$ & 160 & 5 & $\bar{D}$ & 1,513 & 1,664 \\
\hline 2,411 & 180 & 16 & $\bar{A}$ & $\bar{E}$ & $\bar{V}$ & 160 & 5 & $\bar{R}$ & 2,550 & 1,403 \\
\hline 2,412 & 180 & & $S$ & G & $\bar{V}$ & 160 & 5 & D & 1,039 & 1,143 \\
\hline 2,413 & 200 & 13 & A & G & $\mathrm{H}$ & 125 & 5 & $\bar{D}$ & 3,063 & 3,369 \\
\hline 2,414 & 200 & 16 & $\bar{A}$ & $\mathbf{G}$ & $\bar{V}$ & & 5 & $D$ & 1,897 & 2,087 \\
\hline 2,415 & 200 & 13 & A & $\mathbf{G}$ & $\mathrm{V}$ & 125 & 5 & $D$ & 1,823 & 2,005 \\
\hline 2,416 & 200 & 16 & $\bar{A}$ & $\mathbf{G}$ & $\mathrm{V}$ & 150 & 5 & $\bar{R}$ & 3,106 & 2,050 \\
\hline 2,417 & 220 & 16 & $\bar{A}$ & $G$ & $\mathrm{~V}$ & 125 & 5 & $\mathrm{R}$ & 6,741 & 4,449 \\
\hline 2,418 & 220 & 16 & $A$ & $\mathbf{G}$ & $\mathrm{V}$ & 150 & 5 & $R$ & 7,703 & 5,084 \\
\hline 2,419 & 220 & 16 & $\bar{A}$ & $E$ & $\bar{V}$ & 125 & 5 & $R$ & 6,409 & 4,230 \\
\hline 2,420 & 220 & 16 & $\bar{A}$ & $E$ & $\bar{V}$ & 150 & 5 & $\mathrm{R}$ & 6,879 & 4,540 \\
\hline 2,421 & 230 & & $\bar{A}$ & $\bar{E}$ & $\bar{V}$ & & & $R$ & 1,975 & 1,086 \\
\hline 2,422 & 260 & 16 & $\bar{A}$ & $\mathbf{G}$ & V & 125 & 5 & $R$ & 7,932 & 5,235 \\
\hline 2,423 & 260 & 16 & A & $G$ & $\mathrm{~V}$ & 150 & 5 & R & 8,275 & 5,462 \\
\hline 2,424 & 260 & 16 & A & $\mathrm{E}$ & $\bar{V}$ & 125 & 5 & $\bar{R}$ & 7,342 & 4,846 \\
\hline 2,425 & 260 & 16 & $A$ & $E$ & $V$ & 150 & 5 & $\mathrm{R}$ & 7,812 & 5,156 \\
\hline 2,426 & 300 & 16 & A & $\mathbf{G}$ & $\overline{\mathrm{H}}$ & 125 & 5 & $\mathbf{R}$ & 10,201 & 6,733 \\
\hline
\end{tabular}


Table A.4. Unfired Hot Water Storage Tanks (contd)

\begin{tabular}{|c|c|c|c|c|c|c|c|c|c|c|}
\hline REC & VOL & RVAL & TANK & LIN & ORIENT & PRESS & WARR & CTYPE & LCOST & CCOST \\
\hline 2,427 & 300 & 16 & $A$ & $G$ & $\begin{array}{ll} \\
\end{array}$ & 150 & 5 & $\mathrm{R}$ & 10,996 & 7,257 \\
\hline 2,428 & 300 & 16 & A & $E$ & $H$ & 125 & 5 & $\mathbf{R}$ & 9,826 & 6,485 \\
\hline 2,429 & 300 & 16 & A & $E$ & $H$ & 150 & 5 & $\mathbf{R}$ & 10,408 & 6,869 \\
\hline 2,430 & 320 & 16 & A & $E$ & $\bar{V}$ & 125 & 5 & $\mathrm{R}$ & 4,981 & 3,287 \\
\hline 2,431 & 320 & 16 & A & G & $\bar{V}$ & 125 & 5 & $\mathrm{R}$ & 8,227 & 5,430 \\
\hline 2,432 & 320 & 16 & $\bar{A}$ & $G$ & $\bar{V}$ & 150 & 5 & $\mathbf{R}$ & 9,236 & 6,096 \\
\hline 2,433 & 320 & 16 & A & $E$ & V & 125 & 5 & $\mathrm{R}$ & 7,678 & 5,067 \\
\hline 2,434 & 320 & 16 & $\bar{A}$ & $\bar{E}$ & $\bar{V}$ & 150 & 5 & $R$ & 8,262 & 5,453 \\
\hline 2,435 & 330 & & A & $E$ & V & & & $R$ & 2,265 & 1,246 \\
\hline 2,436 & 350 & 13 & $\bar{A}$ & $\bar{G}$ & $\mathrm{H}$ & 125 & 5 & $\mathrm{D}$ & 3,732 & 4,105 \\
\hline 2,437 & 350 & 13 & A & $G$ & $\bar{V}$ & 125 & 5 & $D$ & 3,416 & 3,758 \\
\hline 2,438 & 400 & 13 & $A$ & G & $\mathrm{H}$ & 125 & 5 & $\bar{D}$ & 4,416 & 4,858 \\
\hline 2,439 & 400 & 16 & A & G & $\mathrm{H}$ & 125 & 5 & $\mathrm{R}$ & 11,176 & 7,376 \\
\hline 2,440 & 400 & 16 & $\bar{A}$ & $\dot{\mathbf{G}}$ & $\mathrm{H}$ & 150 & 5 & $R$ & 12,030 & 7,940 \\
\hline 2,441 & 400 & 16 & $\bar{A}$ & $\bar{E}$ & $\mathrm{H}$ & 125 & 5 & $\mathbf{R}$ & 10,574 & 6,979 \\
\hline 2,442 & 400 & 16 & $\bar{A}$ & $E$ & $\overline{\mathrm{H}}$ & 150 & 5 & $R$ & 11,161 & 7,366 \\
\hline 2,443 & 400 & 13 & $\bar{A}$ & $\mathbf{G}$ & V & 125 & 5 & D & 3,874 & 4,261 \\
\hline 2,444 & 430 & 16 & A & $E$ & $\bar{V}$ & 125 & 5 & $R$ & 5,915 & 3,904 \\
\hline 2,445 & 430 & 16 & A & $\mathbf{G}$ & V & 125 & 5 & $R$ & 11,429 & 7,543 \\
\hline 2,446 & 430 & 16 & $\bar{A}$ & $\mathbf{G}$ & $\bar{V}$ & 150 & 5 & $R$ & 12,506 & 8,254 \\
\hline 2,447 & 430 & 16 & A & $E$ & V & 125 & 5 & $\mathrm{R}$ & 9,192 & 6,067 \\
\hline 2,448 & 430 & 16 & $A$ & $E$ & V & 150 & 5 & $R$ & 9,888 & 6,526 \\
\hline 2,449 & 500 & 13 & $\bar{A}$ & G & $\mathrm{H}$ & 125 & 5 & $\mathrm{D}$ & 5,667 & 6,234 \\
\hline 2.450 & 500 & 13 & $\bar{A}$ & $\mathbf{G}$ & $\mathrm{H}$ & 125 & 5 & $\bar{D}$ & 5,864 & 6,450 \\
\hline 2,451 & 500 & 16 & A & G & $\mathrm{H}$ & 125 & 5 & $R$ & 15,988 & 10,552 \\
\hline 2,452 & 500 & 16 & $\bar{A}$ & $\mathbf{G}$ & $\mathrm{H}$ & 150 & 5 & $\mathrm{R}$ & 16,813 & 11,097 \\
\hline 2,453 & 500 & 16 & A & $E$ & $\mathrm{H}$ & 125 & 5 & $R$ & 12,860 & 8,488 \\
\hline 2,454 & 500 & 16 & A & $\bar{E}$ & $\mathrm{H}$ & 150 & 5 & $R$ & 13,568 & 8,955 \\
\hline 2,455 & 500 & 13 & $\bar{A}$ & $\mathbf{G}$ & $\bar{V}$ & 125 & 5 & D & 5,327 & 5,860 \\
\hline 2,456 & 500 & 13 & $A$ & G & $\mathrm{V}$ & 125 & 5 & D & 5,517 & 6,069 \\
\hline 2,457 & 500 & 16 & $\bar{A}$ & $E$ & $\bar{V}$ & 125 & 5 & $\mathbf{R}$ & 6,144 & 4,055 \\
\hline 2,458 & 500 & 16 & A & $G$ & V & 125 & 5 & $\mathbf{R}$ & 11,830 & 7,808 \\
\hline 2,459 & 500 & 16 & A & $G$ & $\bar{V}$ & 150 & 5 & $R$ & 12,784 & 8,437 \\
\hline 2,460 & 500 & 16 & $A$ & $E$ & $\mathrm{~V}$ & 125 & 5 & $\mathrm{R}$ & 9,629 & 6,355 \\
\hline 2,461 & 500 & 16 & A & $\bar{E}$ & V & 150 & 5 & $R$ & 10,333 & 6,820 \\
\hline 2,462 & 530 & & A & $\bar{E}$ & V & & & $R$ & 2,665 & 1,466 \\
\hline 2,463 & 600 & 16 & $\bar{A}$ & $G$ & $\mathrm{H}$ & 125 & 5 & $R$ & 17,752 & 11,716 \\
\hline 2,464 & 600 & 16 & A & $G$ & $\mathrm{H}$ & 150 & 5 & $R$ & 18,644 & 12,305 \\
\hline 2,465 & 600 & 16 & A & $E$ & $\mathrm{H}$ & 125 & 5 & $R$ & 13,429 & 8,863 \\
\hline 2,466 & 600 & 16 & $A$ & $\bar{E}$ & $\mathrm{H}$ & 150 & 5 & $R$ & 14,141 & 9,333 \\
\hline 2,467 & 700 & 16 & A & $G$ & $\mathrm{H}$ & 125 & 5 & $R$ & 18,243 & 12,040 \\
\hline 2,468 & 700 & 16 & A & $G$ & $\mathrm{H}$ & 150 & 5 & $\mathrm{R}$ & 19,227 & 12,690 \\
\hline 2,469 & 700 & 16 & A & $\mathrm{E}$ & $\mathrm{H}$ & 125 & 5 & $\mathrm{R}$ & 14,311 & 9,445 \\
\hline 2,470 & 700 & 16 & $A$ & $E$ & $\mathrm{H}$ & 150 & 5 & $\mathrm{R}$ & 15.013 & 9.909 \\
\hline 2,471 & 750 & 13 & A & $G$ & $\mathrm{H}$ & 125 & 5 & $D$ & 7468 & 8215 \\
\hline
\end{tabular}


Table A.4. Unfired Hot Water Storage Tanks (contd)

\begin{tabular}{|c|c|c|c|c|c|c|c|c|c|c|}
\hline REC & VOL & RVAL & TANK & LIN & ORIENT & PRESS & WARR & CTYPE & LCOST & CCOST \\
\hline 2,472 & 750 & 13 & A & $\mathbf{G}$ & $V$ & 125 & 5 & D & 7,059 & 7,765 \\
\hline 2,473 & 750 & 16 & $\mathrm{~A}$ & G & $\mathrm{V}$ & 125 & 5 & $R$ & 16,166 & 10,670 \\
\hline 2,474 & 750 & 16 & $A$ & $G$ & $\mathrm{~V}$ & 150 & 5 & $R$ & 17,034 & 11,242 \\
\hline 2,475 & 750 & 16 & $A$ & $E$ & $\mathrm{~V}$ & 125 & 5 & $\bar{R}$ & 12,385 & 8,174 \\
\hline 2,476 & 750 & 16 & $\bar{A}$ & $E$ & V & 150 & 5 & $\mathrm{R}$ & 12,790 & 8,441 \\
\hline 2,477 & 800 & 16 & A & G & $\mathrm{H}$ & 125 & 5 & $\mathbf{R}$ & 21,261 & 14,032 \\
\hline 2,478 & 800 & 16 & $\mathrm{~A}$ & $G$ & $\bar{H}$ & 150 & 5 & $\mathbf{R}$ & 22,629 & 14,935 \\
\hline 2,479 & 800 & 16 & A & $E$ & $\mathrm{H}$ & 125 & 5 & $\mathrm{R}$ & 15,552 & 10,264 \\
\hline 2,480 & 800 & 16 & A & $E$ & $\mathrm{H}$ & 150 & 5 & $\mathbf{R}$ & 15,984 & 10,549 \\
\hline 2,481 & 940 & 16 & A & G & V & 125 & 5 & $\mathrm{R}$ & 18,314 & 12,087 \\
\hline 2,482 & 940 & 16 & A & G & V & 150 & 5 & $\mathbf{R}$ & 19,379 & 12,790 \\
\hline 2,483 & 940 & 16 & $\bar{A}$ & $E$ & V & 125 & 5 & R & 13,518 & 8,922 \\
\hline 2,484 & 940 & 16 & A & $E$ & $\bar{V}$ & 150 & 5 & $\mathbf{R}$ & 13,925 & 9,191 \\
\hline 2,485 & 1,000 & 13 & A & G & $\mathrm{H}$ & 125 & 5 & $\bar{D}$ & 9,691 & 10,660 \\
\hline 2,486 & 1,000 & 16 & $\bar{A}$ & G & $H$ & 125 & 5 & $\mathrm{R}$ & 22,717 & 14,993 \\
\hline 2,487 & 1,000 & 16 & $A$ & $G$ & $\mathrm{H}$ & 150 & 5 & $R$ & 23,795 & 15,705 \\
\hline 2,488 & 1,000 & 16 & $\bar{A}$ & $\bar{E}$ & $\overline{\mathrm{H}}$ & 125 & 5 & $\mathrm{R}$ & 16,420 & 10,837 \\
\hline 2,489 & 1,000 & 16 & $\bar{A}$ & $E$ & $\mathrm{H}$ & 150 & 5 & $\mathrm{R}$ & 17,555 & 11,586 \\
\hline 2,490 & 1,000 & 13 & A & $G$ & $\mathrm{~V}$ & 125 & 5 & $D$ & 9,161 & 10,077 \\
\hline 2,491 & 1,250 & 16 & $A$ & $G$ & $\mathrm{H}$ & 125 & 5 & $\mathrm{R}$ & 27,926 & 18,431 \\
\hline 2,492 & 1,250 & 16 & A & G & $\mathrm{H}$ & 150 & 5 & $\bar{R}$ & 29,318 & 19,350 \\
\hline 2,493 & 1,250 & 16 & $A$ & $E$ & $\mathrm{H}$ & 125 & 5 & $\bar{R}$ & 17,150 & 11,319 \\
\hline 2,494 & 1,250 & 16 & A & $E$ & $H$ & 150 & 5 & $R$ & 17,624 & 11,632 \\
\hline 2,495 & 1,250 & 16 & A & $G$ & V & 125 & 5 & $R$ & 24,207 & 15,977 \\
\hline 2,496 & 1,250 & 16 & A & $G$ & V & 150 & 5 & $\mathrm{R}$ & 25,953 & 17,129 \\
\hline 2,497 & 1,250 & 16 & $\bar{A}$ & $E$ & V & 125 & 5 & $\mathbf{R}$ & 15,503 & 10,232 \\
\hline 2,498 & 1,250 & 16 & A & $E$ & V & 150 & 5 & $R$ & 15,976 & 10,544 \\
\hline 2,499 & 1,500 & 16 & $\mathrm{~A}$ & G & $\mathrm{H}$ & 125 & 5 & $\mathrm{R}$ & 30,617 & 20,207 \\
\hline 2,500 & 1,500 & 16 & A & G & $\mathrm{H}$ & 150 & 5 & $\mathbf{R}$ & 35,344 & 23,327 \\
\hline 2,501 & 1,500 & 16 & $\bar{A}$ & $E$ & $\mathrm{H}$ & 125 & 5 & $\mathbf{R}$ & 19,367 & 12,782 \\
\hline 2,502 & 1,500 & 16 & A & $\vec{E}$ & $\mathrm{H}$ & 150 & 5 & $\mathbf{R}$ & 19,886 & 13,125 \\
\hline 2,503 & 1,500 & 16 & $A$ & $\mathbf{G}$ & $\mathrm{V}$ & 125 & 5 & $\overline{\mathbf{R}}$ & 26,096 & 17,223 \\
\hline 2,504 & 1,500 & 16 & A & $\mathbf{G}$ & V & 150 & 5 & $R$ & 30,954 & 20,430 \\
\hline 2,505 & 1,500 & 16 & $\bar{A}$ & $E$ & $V$ & 125 & 5 & $\mathrm{R}$ & 17,054 & 11,256 \\
\hline 2,506 & 1,500 & 16 & A & $E$ & $\bar{V}$ & 150 & 5 & $R$ & 17,580 & 11,603 \\
\hline 2,507 & 2,000 & 16 & $\bar{A}$ & $\mathbf{G}$ & $\mathrm{H}$ & 125 & 5 & $R$ & 37,790 & 24,941 \\
\hline 2,508 & 2,000 & 16 & $A$ & $E$ & $\mathrm{H}$ & 125 & 5 & $\mathrm{R}$ & 23,395 & 15,441 \\
\hline 2,509 & 2,000 & 16 & A & $E$ & $\mathrm{H}$ & 150 & 5 & $\mathrm{R}$ & 24,195 & 15,969 \\
\hline 2,510 & 2,000 & 16 & A & $\mathbf{G}$ & $\mathrm{V}$ & 125 & 5 & $R$ & 36,231 & 23,912 \\
\hline 2,511 & 2,000 & 16 & $A$ & $\mathbf{G}$ & V & 150 & 5 & $R$ & 36,231 & 23,912 \\
\hline 2,512 & 2,000 & 16 & $\bar{A}$ & $E$ & V & 125 & 5 & $\mathrm{R}$ & 20,329 & 13,417 \\
\hline 2,513 & 2,000 & 16 & $A$ & $\bar{E}$ & V & 150 & 5 & $\mathrm{R}$ & 21,125 & 13,943 \\
\hline 2,514 & 2,500 & 16 & $\mathrm{~A}$ & $\mathbf{G}$ & $\mathrm{H}$ & 125 & 5 & $R$ & 44,524 & 29,386 \\
\hline 2,515 & 2,500 & 16 & A & $E$ & $H$ & 125 & 5 & $\bar{R}$ & 24,859 & 16,407 \\
\hline 2,516 & 2,500 & 16 & A & $E$ & $\mathrm{H}$ & 150 & 5 & $R$ & 25,936 & 17,118 \\
\hline
\end{tabular}


Table A.4. Unfired Hot Water Storage Tanks (contd)

\begin{tabular}{|c|c|c|c|c|c|c|c|c|c|c|}
\hline REC & VOL & RVAL & TANK & LIN & ORIENT & PRESS & WARR & CTYPE & LCOST & CCOST \\
\hline 2,517 & 2,500 & 16 & A & G & V & 125 & 5 & R & 38,580 & 25,463 \\
\hline 2,518 & 2,500 & 16 & A & G & V & 150 & 5 & R & 38,580 & 25,463 \\
\hline 2,519 & 2,500 & 16 & A & E & V & 125 & 5 & R & 23,352 & 15,412 \\
\hline 2,520 & 2,500 & 16 & A & E & V & 150 & 5 & R & 24,436 & 16,128 \\
\hline
\end{tabular}


Table A.5. Packaged Boilers

\begin{tabular}{|c|c|c|c|c|c|c|c|c|c|c|c|}
\hline REC & TYPE & FUEL & INPUT & EFF & EXCH & IGN & BURN & VENT & CTYPE & LCOST & CCOST \\
\hline 2,521 & $W$ & $\mathbf{G}$ & 120 & 80 & C & $E$ & $A$ & & $D$ & 4,102 & 4,553 \\
\hline 2,522 & $\bar{W}$ & $\mathbf{G}$ & 250 & 88 & $C$ & $E$ & $P$ & $\mathbf{N}$ & $\mathbf{R}$ & 6,390 & 4,217 \\
\hline 2,523 & $W$ & $\mathbf{G}$ & 300 & 84 & C & $\bar{E}$ & $P$ & $\bar{N}$ & $\overline{\mathrm{R}}$ & 3,133 & 2,068 \\
\hline 2,524 & $W$ & $\mathbf{G}$ & 300 & 84 & C & $\bar{E}$ & $\mathrm{P}$ & $\mathrm{N}$ & $R$ & 3,373 & 2,226 \\
\hline 2,525 & $\bar{W}$ & $\mathbf{G}$ & 300 & 82 & C & $\bar{E}$ & $\bar{A}$ & $\mathbf{N}$ & $\mathrm{D}$ & 2,064 & 2,291 \\
\hline 2,526 & W & G & 320 & 81 & C & $\bar{E}$ & A & $\mathbf{N}$ & $\mathbf{R}$ & 2,211 & 1,459 \\
\hline 2,527 & $W$ & $G$ & 320 & 81 & C & $\bar{E}$ & $A$ & $N$ & $\mathbf{R}$ & 2,361 & 1,558 \\
\hline 2,528 & $\bar{W}$ & $G$ & 320 & 80 & $C$ & $\bar{E}$ & $\bar{A}$ & & $\mathrm{D}$ & 1,920 & 2,131 \\
\hline 2,529 & $\bar{W}$ & G & 320 & 80 & C & $\bar{E}$ & $\bar{A}$ & & $\mathrm{D}$ & 2,014 & 2,236 \\
\hline 2,530 & $W$ & $\mathbf{G}$ & 330 & 82 & $C$ & $\bar{E}$ & $\bar{A}$ & & $\mathbf{R}$ & 3,195 & 1,757 \\
\hline 2,531 & $\bar{W}$ & $G$ & 360 & 81 & C & $\bar{E}$ & $\bar{A}$ & $\mathrm{~N}$ & $\overline{\mathbf{R}}$ & 2,320 & 1,531 \\
\hline 2,532 & $\bar{W}$ & G & 360 & 81 & C & $E$ & $\bar{A}$ & $\mathbf{N}$ & $\mathbf{R}$ & 2,492 & 1,645 \\
\hline 2,533 & $\bar{W}$ & $\mathbf{G}$ & 360 & 80 & C & $E$ & $\bar{A}$ & & $\bar{D}$ & 1,986 & 2,204 \\
\hline 2,534 & $\bar{W}$ & $\bar{G}$ & 360 & 80 & C & $E$ & $\bar{A}$ & & $D$ & 2,090 & 2,320 \\
\hline 2,535 & $\bar{w}$ & $\mathbf{G}$ & 400 & 80 & C & $E$ & $\bar{A}$ & $\mathbf{N}$ & $\bar{R}$ & 3,082 & 2,034 \\
\hline 2,536 & $\bar{W}$ & $\mathbf{G}$ & 400 & 80 & C & $E$ & $A$ & $\mathrm{~N}$ & $\mathbf{R}$ & 3,295 & 2,175 \\
\hline 2,537 & $\bar{W}$ & $G$ & 400 & 81 & C & $\bar{E}$ & $\bar{A}$ & $\mathrm{~N}$ & $\bar{D}$ & 2,516 & 2,793 \\
\hline 2,538 & $w$ & $\mathbf{G}$ & 400 & 82 & C & $\bar{E}$ & $\bar{A}$ & & $\mathbf{R}$ & 3,326 & 1,829 \\
\hline 2,539 & $\bar{W}$ & $\overline{\mathbf{G}}$ & 400 & 84 & C & $E$ & $\bar{P}$ & $\mathbf{N}$ & $\mathbf{R}$ & 4,202 & 2,773 \\
\hline 2,540 & $W$ & $\mathbf{G}$ & 400 & 84 & C & $E$ & $P$ & $N$ & $R$ & 4,482 & 2,958 \\
\hline 2,541 & $w$ & $\overline{\mathbf{G}}$ & 410 & 83 & C & $E$ & A & $\bar{Y}$ & $\bar{R}$ & 7,720 & 5,790 \\
\hline 2,542 & 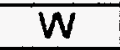 & $\mathbf{G}$ & 420 & 82 & C & $E$ & $A$ & $\mathrm{~N}$ & $D$ & 2,516 & 2,793 \\
\hline 2,543 & $w$ & $\mathbf{G}$ & 480 & 80 & C & $E$ & $\bar{A}$ & & $\bar{D}$ & 2,777 & 3,082 \\
\hline 2,544 & $\bar{W}$ & $\mathbf{G}$ & 480 & 80 & $\mathrm{C}$ & $E$ & A & & $\bar{D}$ & 2,923 & 3,245 \\
\hline 2,545 & $\bar{W}$ & $\bar{G}$ & 490 & 83 & C & $E$ & A & $\bar{Y}$ & R & 7,815 & 5,861 \\
\hline 2,546 & $\bar{W}$ & $\mathbf{G}$ & 500 & 80 & $\bar{C}$ & $\bar{E}$ & $\bar{A}$ & $\bar{N}$ & $R$ & 3,676 & 2,426 \\
\hline 2,547 & $\bar{W}$ & $\mathbf{G}$ & 500 & 84 & $\bar{C}$ & $\bar{E}$ & $P$ & $\bar{N}$ & R & 5,013 & 3,309 \\
\hline 2,548 & $\bar{W}$ & $\mathbf{G}$ & 500 & 88 & C & $\bar{E}$ & $P$ & $N$ & $\mathrm{R}$ & 8,537 & 5,634 \\
\hline 2,549 & 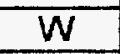 & $G$ & 500 & 80 & C & $E$ & $\mathrm{~A}$ & $\mathrm{~N}$ & $R$ & 3,950 & 2,607 \\
\hline 2,550 & $W$ & $G$ & 500 & 84 & C & $\bar{E}$ & $P$ & $\bar{N}$ & $\mathrm{R}$ & 5,403 & 3,566 \\
\hline 2,551 & $\mathbf{W}$ & $\mathbf{G}$ & 500 & 88 & C & $E$ & $P$ & $\mathrm{~N}$ & D & 5,274 & 5,854 \\
\hline 2,552 & $\bar{W}$ & $\mathbf{G}$ & 510 & 82 & C & $E$ & A & & $\mathbf{R}$ & 4,804 & 2,642 \\
\hline 2,553 & $W$ & $\mathbf{G}$ & 520 & 82 & C & $\bar{E}$ & $\bar{A}$ & $N$ & $D$ & 2,895 & 3,213 \\
\hline 2,554 & $\bar{W}$ & $G$ & 570 & 80 & C & $\bar{E}$ & $\bar{A}$ & & D & 3,205 & 3,558 \\
\hline 2,555 & $\bar{W}$ & $\mathbf{G}$ & 570 & 80 & C & $\bar{E}$ & A & & $\bar{D}$ & 3,371 & 3,742 \\
\hline 2,556 & $W$ & $\mathbf{G}$ & 600 & 83 & C & $E$ & A & $\bar{Y}$ & $\bar{R}$ & 8,002 & 6,002 \\
\hline 2,557 & $\bar{W}$ & $G$ & 630 & 82 & C & $E$ & $\bar{A}$ & & $\mathrm{R}$ & 5,291 & 2,910 \\
\hline 2,558 & $W$ & G & 650 & 84 & C & $\bar{E}$ & $P$ & $\mathrm{~N}$ & $R$ & 5,280 & 3,485 \\
\hline 2,559 & $w$ & G & 650 & 84 & C & $E$ & $P$ & $N$ & $\mathbf{R}$ & 5,720 & 3,775 \\
\hline 2,560 & $W$ & $\mathbf{G}$ & 670 & 80 & C & $E$ & $\bar{A}$ & $\mathrm{~N}$ & $R$ & 3,851 & 2,542 \\
\hline 2,561 & $w$ & $\mathbf{G}$ & 670 & 80 & C & $E$ & $\bar{A}$ & $\bar{N}$ & $\overline{\mathrm{R}}$ & 4,203 & 2,774 \\
\hline 2,562 & $w$ & $\mathbf{G}$ & 670 & 80 & C & $E$ & $\bar{A}$ & & $D$ & 3,310 & 3,674 \\
\hline 2,563 & $w$ & $\mathbf{G}$ & 670 & 80 & C & $E$ & $A$ & & $D$ & 3,502 & 3,887 \\
\hline 2,564 & $\bar{W}$ & $\mathbf{G}$ & 670 & 75 & $\mathrm{C}$ & $\bar{E}$ & $\bar{A}$ & $\bar{N}$ & $\bar{D}$ & 3,309 & 3,673 \\
\hline 2,565 & $w$ & G & 700 & 83 & C & $E$ & $A$ & $\bar{Y}$ & $\mathrm{R}$ & 8,109 & 6.082 \\
\hline
\end{tabular}


Table A.5. Packaged Boilers (contd)

\begin{tabular}{|c|c|c|c|c|c|c|c|c|c|c|c|}
\hline REC & TYPE & FUEL & INPUT & EFF & $\mathrm{EXCH}$ & IGN & BURN & VENT & CTYPE & LCOST & CcosT \\
\hline 2,566 & W & $\mathbf{G}$ & 720 & 82 & C & $E$ & $A$ & $\mathbf{N}$ & D & 2,385 & 2,647 \\
\hline 2,567 & W & $\mathbf{G}$ & 730 & 82 & C & $E$ & A & & $R$ & 5,699 & 3,134 \\
\hline 2,568 & W & $\mathbf{G}$ & 750 & 84 & C & $E$ & $P$ & $\mathbf{N}$ & $R$ & 5,451 & 3,598 \\
\hline 2,569 & W & $\mathbf{G}$ & 750 & 88 & C & $E$ & $P$ & $N$ & $\mathrm{R}$ & 9,315 & 6,148 \\
\hline 2,570 & $W$ & G & 750 & 84 & C & $\bar{E}$ & $P$ & $N$ & $R$ & 4,901 & 3,235 \\
\hline 2,571 & $W$ & G & 750 & 88 & C & $\bar{E}$ & $P$ & $\mathrm{~N}$ & D & 5,766 & 6,400 \\
\hline 2,572 & $W$ & $G$ & 760 & 80 & $C$ & $\vec{E}$ & $A$ & $N$ & $\mathbf{R}$ & 3,998 & 2,639 \\
\hline 2,573 & $\mathbf{W}$ & $\mathrm{G}$ & 760 & 80 & C & $\bar{E}$ & A & $N$ & $\mathrm{R}$ & 4,382 & 2,892 \\
\hline 2,574 & $w$ & $\mathbf{G}$ & 760 & 80 & $C$ & $E$ & A & & D & 3,422 & 3,798 \\
\hline 2,575 & $w$ & G & 760 & 80 & C & $E$ & A & & D & 3,630 & 4,029 \\
\hline 2,576 & $w$ & $\mathbf{G}$ & 810 & 83 & C & $E$ & $A$ & $Y$ & $\mathbf{R}$ & 8,670 & 6,503 \\
\hline 2,577 & $w$ & $\mathbf{G}$ & 830 & 82 & $c$ & $E$ & $\bar{A}$ & & $\mathbf{R}$ & 6,209 & 3,415 \\
\hline 2,578 & $W$ & $G$ & 840 & 82 & $C$ & $\bar{E}$ & $A$ & $N$ & D & 2,520 & 2,797 \\
\hline 2,579 & $W$ & $\mathbf{G}$ & 860 & 80 & C & $E$ & A & & D & 3,728 & 4,138 \\
\hline 2,580 & $W$ & G & 860 & 80 & C & $E$ & A & & D & 3,962 & 4,398 \\
\hline 2,581 & $w$ & G & 940 & 80 & C & $\bar{E}$ & A & $N$ & $R$ & 4,866 & 3,212 \\
\hline 2,582 & $W$ & $G$ & 940 & 80 & C & $E$ & A & $\bar{N}$ & $\mathrm{R}$ & 5,333 & 3,520 \\
\hline 2,583 & $w$ & $\mathbf{G}$ & 940 & 80 & C & $E$ & A & & D & 3,845 & 4,268 \\
\hline 2,584 & $W$ & $\mathbf{G}$ & 940 & 80 & C & $E$ & A & & D & 4,105 & 4,557 \\
\hline 2,585 & $w$ & $\mathbf{G}$ & 950 & 83 & C & $E$ & A & $\mathrm{Y}$ & $\mathbf{R}$ & 9,052 & 6,789 \\
\hline 2,586 & $\mathrm{~W}$ & $\mathbf{G}$ & 960 & 82 & C & $\bar{E}$ & A & $N$ & D & 2,700 & 2,997 \\
\hline 2,587 & $w$ & $\mathbf{G}$ & 960 & 82 & C & $\overline{\mathrm{E}}$ & A & & $R$ & 6,540 & 3,597 \\
\hline$\frac{2,501}{2,588}$ & $w$ & $G$ & 990 & 84 & C & $\bar{E}$ & $P$ & $N$ & $R$ & 6,756 & 4,459 \\
\hline 2,589 & W & G & 990 & 84 & C & $\bar{E}$ & $P$ & $N$ & $\mathbf{R}$ & 7,226 & 4,769 \\
\hline 2,590 & $W$ & $\mathbf{G}$ & 1,000 & 88 & C & $\bar{E}$ & $P$ & $N$ & $R$ & 10,104 & 6,669 \\
\hline 2,591 & $W$ & $\mathbf{G}$ & 1,000 & 88 & C & $E$ & $P$ & $\bar{N}$ & D & 6,150 & 6,827 \\
\hline 2,592 & $W$ & $\mathbf{G}$ & 1,080 & 82 & C & $E$ & A & $\mathrm{N}$ & D & 2,880 & 3,197 \\
\hline 2,593 & $W$ & $\mathbf{G}$ & 1,110 & 83 & C & $\bar{E}$ & A & $\bar{Y}$ & $\mathbf{R}$ & 9,472 & 7,104 \\
\hline 2,594 & W & $\mathbf{G}$ & 1,120 & 80 & C & $E$ & A & & D & 4,404 & 4,888 \\
\hline 2,595 & $W$ & $\mathbf{G}$ & 1,120 & 82 & C & $\bar{E}$ & A & & $R$ & 6,894 & 3,792 \\
\hline 2,596 & $w$ & $G$ & 1,210 & 80 & C & $\bar{E}$ & A & $N$ & $R$ & $5 ; 829$ & 3,847 \\
\hline 2,597 & W & $\mathbf{G}$ & 1,210 & 80 & C & $\bar{E}$ & A & $N$ & $R$ & 6,425 & 4,241 \\
\hline 2,598 & $W$ & $\mathbf{G}$ & 1,210 & 80 & C & $\bar{E}$ & A & & D & 4,346 & 4,824 \\
\hline 2,599 & $W$ & $\mathbf{G}$ & 1,210 & 80 & C & $E$ & A & & D & 4,674 & 5,188 \\
\hline 2,600 & $W$ & $\mathbf{G}$ & 1,210 & 82 & C & $E$ & A & $\mathbf{N}$ & D & 3,060 & 3,397 \\
\hline 2,601 & W & $\mathbf{G}$ & 1,220 & 82 & $c$ & $\bar{E}$ & A & & $\mathrm{R}$ & 7,420 & 4,081 \\
\hline 2,602 & $w$ & $\mathbf{G}$ & 1,240 & 80 & C & $E$ & $A$ & $N$ & D & 6,046 & 6,711 \\
\hline 2,603 & $W$ & $\mathbf{G}$ & 1,260 & 84 & C & $E$ & $P$ & $\bar{N}$ & $\mathrm{R}$ & 8,092 & 5,341 \\
\hline 2,604 & W & $\mathbf{G}$ & 1,260 & 84 & C & $\bar{E}$ & $P$ & $\mathrm{~N}$ & $R$ & 8,692 & 5,737 \\
\hline 2,605 & $W$ & G & 1,300 & 83 & C & $E$ & A & $Y$ & $R$ & 9,900 & 7,425 \\
\hline 2,606 & $\mathrm{~W}$ & $\mathbf{G}$ & 1,340 & 82 & C & $\bar{E}$ & A & & $\mathrm{R}$ & 8,321 & 4,577 \\
\hline 2,607 & $W$ & $\mathbf{G}$ & 1,340 & 76 & C & $E$ & $A$ & $N$ & D & 6,519 & 7,236 \\
\hline 2,608 & W & $G$ & 1,350 & 80 & C & $\bar{E}$ & A & & D & 4,847 & 5,380 \\
\hline 2,609 & $W$ & $\mathbf{G}$ & 1,350 & 80 & C & $E$ & $\bar{A}$ & & $D$ & 5,216 & 5,790 \\
\hline 2,610 & W & $\mathbf{G}$ & 1,350 & 82 & C & $\mathbf{E}$ & A & $\mathbf{N}$ & $\mathrm{D}$ & 3,465 & 3,846 \\
\hline
\end{tabular}


Table A.5. Packaged Boilers (contd)

\begin{tabular}{|c|c|c|c|c|c|c|c|c|c|c|c|}
\hline REC & TYPE & FUEL & INPUT & EFF & $\overline{\mathrm{EXCH}}$ & IGN & BURN & VENT & CTYPE & LCOST & $\overline{\text { CCOST }}$ \\
\hline 2,611 & $W$ & G & 1,440 & 84 & C & $E$ & $P$ & $N$ & $R$ & 8,243 & 5,440 \\
\hline 2,612 & $w$ & $\mathbf{G}$ & 1,440 & 84 & C & $E$ & $\bar{P}$ & $\mathbf{N}$ & $\mathbf{R}$ & 8,983 & 5,929 \\
\hline 2,613 & $W$ & $\mathbf{G}$ & 1,470 & 82 & C & $E$ & A & & $\mathbf{R}$ & 8,837 & 4,860 \\
\hline 2,614 & $w$ & $\mathbf{G}$ & 1,480 & 82 & C & $E$ & $\bar{A}$ & $\mathrm{~N}$ & $\mathrm{D}$ & 3,645 & 4,046 \\
\hline 2,615 & $W$ & $\mathbf{G}$ & $1,520^{\circ}$ & 83 & $\mathrm{C}$ & $E$ & $\mathrm{~A}$ & $Y$ & $\mathbf{R}$ & 10,417 & 7,813 \\
\hline 2,616 & $W$ & G & 1,540 & 80 & C & $\bar{E}$ & $\mathrm{~A}$ & $\mathbf{N}$ & $\mathbf{R}$ & 6,382 & 4,212 \\
\hline 2,617 & $W$ & $\mathbf{G}$ & 1,540 & 80 & C & $\bar{E}$ & A & $\mathbf{N}$ & $\mathbf{R}$ & 7,150 & 4,719 \\
\hline 2,618 & $W$ & $\mathbf{G}$ & 1,540 & 80 & C & $E$ & A & & D & 5,137 & 5,702 \\
\hline 2,619 & $w$ & $\mathbf{G}$ & 1,540 & 80 & C & $E$ & $A$ & & D & 5,553 & 6,164 \\
\hline 2,620 & $W$ & $\mathbf{G}$ & 1,610 & 82 & C & $\vec{E}$ & A & $\mathrm{N}$ & D & 3,960 & 4,396 \\
\hline 2,621 & $W$ & G & 1,630 & 82 & C & $E$ & $A$ & & $\mathbf{R}$ & 9,436 & 5,190 \\
\hline 2,622 & $\bar{W}$ & $G$ & 1,690 & 80 & $\mathrm{C}$ & $E$ & $\bar{A}$ & $N$ & $\mathrm{R}$ & 6,812 & 4,496 \\
\hline 2,623 & $W$ & $\mathbf{G}$ & 1,690 & 80 & C & $E$ & A & $\bar{N}$ & $\mathrm{R}$ & 7,638 & 5,041 \\
\hline 2,624 & $W$ & $\mathbf{G}$ & 1,690 & 80 & C & $\bar{E}$ & A & & D & 5,561 & 6,173 \\
\hline 2,625 & $w$ & G & 1,690 & 80 & C & $\bar{E}$ & A & & D & 6,013 & 6,674 \\
\hline 2,626 & $W$ & $\mathbf{G}$ & 1,770 & 83 & C & $E$ & $A$ & $Y$ & $R$ & 10,770 & 8,078 \\
\hline 2,627 & $W$ & $\mathbf{G}$ & 1,800 & 84 & C & $E$ & $P$ & $\mathbf{N}$ & $\mathbf{R}$ & 8,759 & 5,781 \\
\hline 2,628 & W & $G$ & 1,800 & 84 & C & $E$ & $P$ & $\mathrm{~N}$ & $R$ & 9,679 & 6,388 \\
\hline 2,629 & $W$ & $G$ & 1,810 & 82 & C & $E$ & $A$ & $\mathrm{~N}$ & D & 4,320 & 4,795 \\
\hline 2,630 & W & $\mathbf{G}$ & 1,830 & 82 & C & $E$ & A & & $R$ & 10,329 & 5,681 \\
\hline 2,631 & $w$ & $\mathbf{G}$ & 1,880 & 83 & C & $E$ & A & $\bar{Y}$ & $R$ & 14,033 & 10,524 \\
\hline 2,632 & $W$ & G & 2,000 & 80 & C & $E$ & A & $\mathrm{N}$ & $R$ & 8,784 & 5,797 \\
\hline 2,633 & $W$ & $\mathbf{G}$ & 2,000 & 80 & C & $E$ & A & $\mathrm{N}$ & $\mathbf{R}$ & 9,746 & 6,432 \\
\hline 2,634 & $\bar{W}$ & $\mathbf{G}$ & 2,000 & 80 & C & $E$ & $\mathrm{~A}$ & & $D$ & 6,769 & 7,514 \\
\hline 2,635 & $\bar{W}$ & G & 2,000 & 80 & C & $E$ & $\mathrm{~A}$ & & D & 7,289 & 8,091 \\
\hline 2,636 & $\bar{W}$ & G & 2,070 & 84 & C & $E$ & $P$ & $N$ & $\mathrm{R}$ & 11,292 & 7,453 \\
\hline 2,637 & $W$ & G & 2,070 & 84 & C & $\bar{E}$ & $P$ & $N$ & $\mathrm{R}$ & 12,282 & 8,106 \\
\hline 2,638 & $W$ & G & 2,100 & 82 & C & $E$ & A & & $\mathbf{R}$ & 12,666 & 6,966 \\
\hline 2,639 & $W$ & G & 2,200 & 83 & C & $E$ & A & $\bar{Y}$ & $\mathbf{R}$ & 14,918 & 11,188 \\
\hline 2,640 & W & $\mathbf{G}$ & 2,310 & 80 & C & $E$ & A & $N$ & $R$ & 9,193 & 6,067 \\
\hline 2,641 & $W$ & $\mathbf{G}$ & 2,310 & 80 & C & $E$ & $\bar{A}$ & $\bar{N}$ & $\mathrm{R}$ & 10,281 & 6,785 \\
\hline 2,642 & $W$ & $\mathbf{G}$ & 2,310 & 80 & C & $E$ & A & & D & 7,077 & 7,855 \\
\hline 2,643 & $W$ & $\mathbf{G}$ & 2,310 & 80 & C & $E$ & $A$ & & $\bar{D}$ & 7,670 & 8,514 \\
\hline 2,644 & $w$ & $\mathbf{G}$ & 2,500 & 82 & C & $E$ & $A$ & & $\mathbf{R}$ & 13,528 & 7,440 \\
\hline 2,645 & $w$ & $\mathbf{G}$ & 2,570 & 83 & C & $E$ & A & $\bar{Y}$ & $\mathbf{R}$ & 15,908 & 11,931 \\
\hline 2,646 & $W$ & $\mathbf{G}$ & 2,620 & 80 & C & $\bar{E}$ & $A$ & $\mathrm{~N}$ & $\mathrm{R}$ & 10,201 & 6,733 \\
\hline 2,647 & W & $\mathbf{G}$ & 2,620 & 80 & C & $\bar{E}$ & $\bar{A}$ & $N$ & $R$ & 11,417 & 7,535 \\
\hline 2,648 & $W$ & $\mathbf{G}$ & 2,620 & 80 & C & $E$ & $A$ & & $\bar{D}$ & 7,835 & 8,697 \\
\hline 2,649 & $W$ & $\mathbf{G}$ & 2,620 & 80 & $C$ & $E$ & $A$ & & D & 8,501 & 9,436 \\
\hline 2,650 & $W$ & $\mathbf{G}$ & 3,000 & 83 & $C$ & $E$ & $\mathrm{~A}$ & $Y$ & $R$ & 18,630 & 13,973 \\
\hline 2,651 & $W$ & $G$ & 3,000 & 82 & $C$ & $E$ & A & & $\mathrm{R}$ & 16,115 & 8,863 \\
\hline 2,652 & $W$ & $\mathbf{G}$ & 3,080 & 80 & C & $E$ & A & $N$ & $\mathrm{R}$ & 11,608 & 7,661 \\
\hline 2,653 & $W$ & $G$ & 3,080 & 80 & C & $\bar{E}$ & A & $\mathrm{N}$ & $R$ & 13,024 & 8,596 \\
\hline 2,654 & $W$ & $\mathbf{G}$ & 3,080 & 80 & C & $E$ & A & & D & 8,598 & 9,544 \\
\hline 2,655 & $w$ & $G$ & 3,080 & 80 & C & $E$ & $\mathrm{~A}$ & & $\mathrm{D}$ & 9,373 & 10,404 \\
\hline
\end{tabular}


Table A.5. Packaged Boilers (contd)

\begin{tabular}{|c|c|c|c|c|c|c|c|c|c|c|c|}
\hline REC & TYPE & FUEL & INPUT & EFF & $\mathrm{EXCH}$ & IGN & BURN & VENT & CTYPE & LCOST & $\overline{C C O S T}$ \\
\hline 2,656 & $W$ & $\mathbf{G}$ & 3,490 & 83 & C & $E$ & A & $Y$ & $\mathbf{R}$ & 19,770 & 14,828 \\
\hline 2,657 & $W$ & $\mathbf{G}$ & 3,500 & 82 & C & $E$ & A & & $\mathbf{R}$ & 17,517 & 9,634 \\
\hline 2,658 & $w$ & $\mathbf{G}$ & 4,000 & 82 & C & $E$ & $A$ & & $\mathbf{R}$ & 18,921 & 10,407 \\
\hline 2,659 & $W$ & $\mathbf{G}$ & 4,000 & 83 & C & $E$ & $\bar{A}$ & $\mathrm{Y}$ & $\mathbf{R}$ & 20,580 & 15,435 \\
\hline 2,660 & $\mathrm{~S}$ & $\mathbf{G}$ & 100 & 80 & $T$ & $E$ & $A$ & $\mathbf{N}$ & $\mathbf{R}$ & 7,287 & 4,372 \\
\hline 2,661 & $w$ & $\mathbf{G}$ & 300 & 83 & $\mathrm{~T}$ & $E$ & $P$ & $N$ & $\mathbf{R}$ & 4,752 & 2,614 \\
\hline 2,662 & $\bar{W}$ & $\mathbf{G}$ & 300 & 80 & 1 & $\bar{E}$ & $A$ & $\mathbf{N}$ & $\mathbf{R}$ & 3,608 & 1,984 \\
\hline 2,663 & $\mathrm{~s}$ & $\mathbf{G}$ & 300 & 80 & 1 & $E$ & $A$ & $\mathbf{N}$ & $\mathbf{R}$ & 3,908 & 2,149 \\
\hline 2,664 & $W$ & $\mathbf{G}$ & 300 & 80 & 1 & $P$ & A & $\mathrm{N}$ & $\mathbf{R}$ & 2,209 & 1,336 \\
\hline 2,665 & $W$ & $\mathbf{G}$ & 300 & 80 & 1 & $E$ & $\mathrm{~A}$ & $\bar{Y}$ & $\mathbf{R}$ & 2,494 & 1,509 \\
\hline 2,666 & $\bar{W}$ & $\mathbf{G}$ & 300 & 80 & 1 & $E$ & $\bar{A}$ & $\mathrm{~N}$ & $\mathbf{R}$ & 2,330 & 1,410 \\
\hline 2,667 & $\bar{W}$ & $\mathbf{G}$ & 300 & 80 & 1 & $P$ & $A$ & $\mathrm{~N}$ & $\mathrm{R}$ & 2,641 & 1,664 \\
\hline 2,668 & $S$ & $\mathbf{G}$ & 300 & 80 & 1 & $\bar{P}$ & $\bar{A}$ & $N$ & $\mathbf{R}$ & 2,751 & 1,733 \\
\hline 2,669 & W & $\mathbf{G}$ & 300 & 80 & 1 & $E$ & $A$ & $N$ & R & 2,953 & 1,772 \\
\hline 2,670 & $S$ & $\mathbf{G}$ & 300 & 80 & 1 & $E$ & $A$ & $N$ & $R$ & 3,122 & 1,873 \\
\hline 2,671 & $\mathrm{~W}$ & $\mathrm{G}$ & 310 & 81 & 1 & $\bar{E}$ & $A$ & $\bar{N}$ & $R$ & 1,922 & 1,518 \\
\hline 2,672 & $W$ & $\mathbf{G}$ & 310 & 81 & 1 & $P$ & $A$ & $\mathrm{~N}$ & $\mathbf{R}$ & 1,810 & 1,430 \\
\hline 2,673 & $\overline{\mathbf{W}}$ & $\mathbf{G}$ & 330 & 80 & 1 & $\bar{P}$ & $\bar{A}$ & $\bar{N}$ & $\bar{R}$ & 2,428 & 1,469 \\
\hline 2,674 & W & $\mathbf{G}$ & 330 & 80 & 1 & $E$ & $A$ & $Y$ & $R$ & 2,712 & 1,641 \\
\hline 2,675 & $\bar{W}$ & $\mathbf{G}$ & 330 & 80 & 1 & $E$ & A & $\mathbf{N}$ & $\mathrm{R}$ & 2,549 & 1,542 \\
\hline 2,676 & $\mathbf{W}$ & $\mathbf{G}$ & 340 & 80 & 1 & $E$ & $P$ & $\bar{N}$ & $\bar{R}$ & 5,223 & 3,656 \\
\hline 2,677 & $S$ & $\mathbf{G}$ & 340 & 80 & 1 & $\mathrm{E}$ & $P$ & $\mathbf{N}$ & $\mathbf{R}$ & 5,212 & 3,648 \\
\hline 2,678 & $S$ & $\mathbf{G}$ & 350 & 82 & 1 & $\mathrm{E}$ & $P$ & $\bar{Y}$ & $\mathrm{R}$ & 5,224 & 3,657 \\
\hline 2,679 & $\bar{W}$ & $\mathbf{G}$ & 350 & 82 & 1 & $E$ & $P$ & $\bar{Y}$ & $\mathrm{R}$ & 5,224 & 3,657 \\
\hline 2,680 & $W$ & G & 350 & 80 & $I$ & $P$ & A & $\mathrm{N}$ & $\mathrm{R}$ & 2,606 & 1,577 \\
\hline 2,681 & $W$ & $\mathbf{G}$ & 350 & 80 & $I$ & $E$ & $A$ & $\bar{Y}$ & $\mathrm{R}$ & 2,892 & 1,750 \\
\hline 2,682 & $W$ & $\mathbf{G}$ & 350 & 80 & 1 & $E$ & $A$ & $\mathbf{N}$ & $R$ & 2,727 & 1,650 \\
\hline 2,683 & $\mathrm{~S}$ & $\mathbf{G}$ & 350 & 80 & 1 & $E$ & $\bar{A}$ & $\bar{N}$ & $\mathrm{R}$ & 2,764 & 2,184 \\
\hline 2,684 & $\bar{W}$ & $\mathbf{G}$ & 350 & 80 & 1 & $E$ & A & $\bar{N}$ & $\bar{R}$ & 2,561 & 2,023 \\
\hline 2,685 & $S$ & G & 350 & 80 & I & $P$ & A & $\mathrm{N}$ & $\mathrm{R}$ & 2,639 & 2,085 \\
\hline 2,686 & W & $\mathbf{G}$ & 350 & 80 & $\mathrm{I}$ & $P$ & A & $N$ & $\mathrm{R}$ & 2,433 & 1,922 \\
\hline 2,687 & $W$ & $\mathbf{G}$ & 370 & 81 & I & $E$ & A & $N$ & $\bar{R}$ & 2,324 & 1,836 \\
\hline 2,688 & $\bar{W}$ & $\mathbf{G}$ & 370 & 81 & I & $P$ & $\bar{A}$ & $\mathbf{N}$ & $\mathrm{R}$ & 2,210 & 1,746 \\
\hline 2,689 & $W$ & $\mathbf{G}$ & 370 & 83 & $I$ & $E$ & $\mathbf{P}$ & $\mathrm{N}$ & $R$ & 5,096 & 2,803 \\
\hline 2,690 & $w$ & $\bar{G}$ & 380 & 80 & 1 & $\bar{P}$ & $\bar{A}$ & $\bar{N}$ & $R$ & 2,802 & 1,695 \\
\hline 2,691 & $w$ & $G$ & 380 & 80 & 1 & $E$ & $A$ & $\bar{Y}$ & $R$ & 3,088 & 1,868 \\
\hline 2,692 & $\bar{W}$ & $G$ & 380 & 80 & $T$ & $E$ & A & $\mathbf{N}$ & $\mathrm{R}$ & 2,922 & 1,768 \\
\hline 2,693 & $W$ & G & 400 & 80 & 1 & $P$ & A & $\mathrm{N}$ & $R$ & 3,050 & 1,922 \\
\hline 2,694 & $S$ & $G$ & 400 & 80 & 1 & $\mathrm{P}$ & A & $\mathbf{N}$ & $\mathrm{R}$ & 3,163 & 1,993 \\
\hline 2,695 & $\mathbf{W}$ & $\mathbf{G}$ & 400 & 80 & 1 & $E$ & $A$ & $\mathbf{N}$ & $R$ & 4,079 & 2,243 \\
\hline 2,696 & $S$ & $\mathbf{G}$ & 400 & 80 & 1 & $\bar{E}$ & A & $N$ & $R$ & 4,380 & 2,409 \\
\hline 2,697 & W & $\mathbf{G}$ & 400 & 80 & 1 & $\bar{P}$ & A & $N$ & $R$ & 3,050 & 1,922 \\
\hline 2,698 & $S$ & $\mathbf{G}$ & 400 & 80 & 1 & $P$ & A & $\mathrm{N}$ & $\bar{R}$ & 3,163 & 1,993 \\
\hline 2,699 & $\mathrm{~W}$ & $\mathbf{G}$ & 400 & 80 & 1 & $E$ & A & $N$ & $R$ & 3,568 & 2,141 \\
\hline 2,700 & $\mathrm{~S}$ & $\mathbf{G}$ & 400 & 80 & 1 & $E$ & $A$ & $N$ & $R$ & 3,738 & 2,243 \\
\hline
\end{tabular}


Table A.5. Packaged Boilers (contd)

\begin{tabular}{|c|c|c|c|c|c|c|c|c|c|c|c|}
\hline REC & TYPE & FUEL & INPUT & EFF & $\mathrm{EXCH}$ & IGN & BURN & VENT & CTYPE & LCOST & $\overline{C \cos T}$ \\
\hline 2,701 & $\mathrm{~S}$ & $\mathbf{G}$ & 400 & 80 & 1 & $E$ & $A$ & $\mathbf{N}$ & $R$ & 3,012 & 2,379 \\
\hline 2,702 & $W$ & $G$ & 400 & 80 & 1 & $E$ & $\mathrm{~A}$ & $\mathrm{~N}$ & $\mathbf{R}$ & 2,809 & 2,219 \\
\hline 2,703 & $s$ & $\mathbf{G}$ & 400 & 80 & 1 & $P$ & $\mathrm{~A}$ & $\mathrm{~N}$ & $\mathbf{R}$ & 2,888 & 2,282 \\
\hline 2,704 & $W$ & $\mathbf{G}$ & 400 & 80 & I & $P$ & A & $\mathrm{N}$ & $\mathbf{R}$ & 2,682 & 2,119 \\
\hline 2,705 & $W$ & $\mathbf{G}$ & 420 & 80 & 1 & $E$ & $\mathbf{P}$ & $\mathrm{N}$ & $\mathbf{R}$ & 7,132 & 4,992 \\
\hline 2,706 & $S$ & $\mathbf{G}$ & 420 & 80 & 1 & $E$ & $\mathbf{P}$ & $N$ & $\mathbf{R}$ & 6,943 & 4,860 \\
\hline 2,707 & $W$ & $G$ & 430 & 81 & 1 & $E$ & A & $N$ & $\mathbf{R}$ & 2,711 & 2,142 \\
\hline 2,708 & $\bar{W}$ & $\mathbf{G}$ & 450 & 83 & 1 & $E$ & $P$ & $\mathrm{~N}$ & $\mathbf{R}$ & 5,520 & 3,036 \\
\hline 2,709 & $S$ & G & 450 & 80 & 1 & $E$ & $\mathrm{~A}$ & $\mathrm{~N}$ & $\mathbf{R}$ & 3,401 & 2,687 \\
\hline 2,710 & $W$ & $G$ & 450 & 80 & 1 & $E$ & $\bar{A}$ & $\mathrm{~N}$ & $\mathrm{R}$ & 3,198 & 2,526 \\
\hline 2,711 & $\mathrm{~S}$ & G & 490 & 82 & 1 & $E$ & $P$ & $\bar{Y}$ & $R$ & 6,091 & 4,264 \\
\hline 2,712 & $w$ & $\mathbf{G}$ & 490 & 82 & 1 & $E$ & $P$ & $Y$ & $\mathrm{R}$ & 6,091 & 4,264 \\
\hline 2,713 & $\bar{W}$ & $G$ & 500 & 80 & $I$ & $E$ & $A$ & $N$ & $\mathrm{R}$ & 4,550 & 2,503 \\
\hline 2,714 & S & $G$ & 500 & 80 & I & $E$ & $\mathrm{~A}$ & $\mathrm{~N}$ & $\mathrm{R}$ & 4,860 & 2,673 \\
\hline 2,715 & $\bar{W}$ & $G$ & 500 & 80 & 1 & $P$ & A & $\mathrm{N}$ & $\mathrm{R}$ & 3,602 & 2,269 \\
\hline 2,716 & $S$ & $\mathbf{G}$ & 500 & 80 & 1 & $P$ & A & $N$ & $\mathrm{R}$ & 3,717 & 2,342 \\
\hline 2,717 & $\mathbf{W}$ & $\mathbf{G}$ & 500 & 80 & 1 & $E$ & A & $\mathrm{N}$ & $\mathrm{R}$ & 4,039 & 2,423 \\
\hline 2,718 & $\mathrm{~s}$ & $\mathbf{G}$ & 500 & 80 & 1 & $E$ & A & $N$ & $R$ & 4,209 & 2,525 \\
\hline 2,719 & $\mathrm{~S}$ & $\mathbf{G}$ & 500 & 80 & 1 & $E$ & A & $\mathrm{N}$ & $\mathrm{R}$ & 3,621 & 2,861 \\
\hline 2,720 & $W$ & $\mathbf{G}$ & 500 & 80 & 1 & $E$ & $\mathrm{~A}$ & $\mathrm{~N}$ & $\mathrm{R}$ & 3,418 & 2,700 \\
\hline 2,721 & 5 & $\mathbf{G}$ & 550 & 80 & 1 & $E$ & A & $\mathrm{N}$ & $\mathrm{R}$ & 3,872 & 3,059 \\
\hline 2,722 & $W$ & $\mathbf{G}$ & 550 & 80 & 1 & $E$ & A & $\mathrm{N}$ & $\mathbf{R}$ & 3,669 & 2,899 \\
\hline 2,723 & $\mathbf{W}$ & $\mathbf{G}$ & 560 & 80 & 1 & $E$ & $P$ & $\mathrm{~N}$ & $\mathbf{R}$ & 8,069 & 5,648 \\
\hline 2,724 & $W$ & G & 560 & 83 & 1 & $E$ & $P$ & $\mathrm{~N}$ & $\mathrm{R}$ & 7,644 & 4,204 \\
\hline 2,725 & $S$ & G & 570 & 80 & 1 & $E$ & $P$ & $\mathbf{N}$ & $\mathbf{R}$ & 7,900 & 5,530 \\
\hline 2,726 & $W$ & $\mathbf{G}$ & 600 & 83 & 1 & $E$ & $P$ & $\mathrm{~N}$ & $\bar{R}$ & 9,504 & 5,227 \\
\hline 2,727 & $w$ & $\mathbf{G}$ & 600 & 80 & 1 & $E$ & A & $\mathbf{N}$ & $R$ & 6,149 & 3,382 \\
\hline 2,728 & $S$ & $G$ & 600 & 80 & 1 & $E$ & A & $\mathrm{N}$ & $\mathrm{R}$ & 6,458 & 3,552 \\
\hline 2,729 & $W$ & $\mathbf{G}$ & 600 & 80 & 1 & $P$ & A & $\mathrm{N}$ & $R$ & 4,469 & 2,815 \\
\hline 2,730 & $S$ & $\mathbf{G}$ & 600 & 80 & 1 & $P$ & 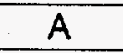 & $\mathrm{N}$ & $\mathrm{R}$ & 4,646 & 2,927 \\
\hline 2,731 & $W$ & $\mathbf{G}$ & 600 & 80 & 1 & $E$ & $A$ & $\mathrm{~N}$ & $\mathrm{R}$ & 4,917 & 2,950 \\
\hline 2,732 & $\mathrm{~S}$ & $\mathbf{G}$ & 600 & 80 & $T$ & $E$ & $\mathrm{~A}$ & $\mathrm{~N}$ & $R$ & 5,097 & 3,058 \\
\hline 2,733 & $\mathrm{~S}$ & $\mathbf{G}$ & 640 & 82 & 1 & $E$ & $P$ & $\bar{Y}$ & $\mathrm{R}$ & 6,622 & 4,635 \\
\hline 2,734 & $\bar{W}$ & $\mathbf{G}$ & 640 & 82 & 1 & $E$ & $P$ & $\bar{Y}$ & $R$ & 6,622 & 4,635 \\
\hline 2,735 & $W$ & G & 650 & 81 & 1 & $E$ & A & $\mathrm{N}$ & $\mathrm{R}$ & 6,347 & 5,014 \\
\hline 2,736 & $S$ & $\mathbf{G}$ & 650 & 81 & 1 & $E$ & A & $\mathbf{N}$ & $\mathrm{R}$ & 6,545 & 5,171 \\
\hline 2,737 & $W$ & $\mathbf{G}$ & 680 & 83 & 1 & $E$ & $P$ & $N$ & $\mathbf{R}$ & 8,280 & 4,554 \\
\hline 2,738 & $W$ & $\mathbf{G}$ & 700 & 80 & 1 & $E$ & $\mathrm{~A}$ & $N$ & $R$ & 6,667 & 3,667 \\
\hline 2,739 & $S$ & $\mathbf{G}$ & 700 & 80 & 1 & $E$ & $\bar{A}$ & $\mathrm{~N}$ & $\mathbf{R}$ & 6,932 & 3,813 \\
\hline 2,740 & $W$ & $\mathbf{G}$ & 700 & 80 & 1 & $P$ & $\bar{A}$ & $\mathrm{~N}$ & $\mathrm{R}$ & 4,896 & 3,084 \\
\hline 2,741 & $S$ & $G$ & 700 & 80 & 1 & $P$ & $A$ & $N$ & $R$ & 5,047 & 3,180 \\
\hline 2,742 & $W$ & $\mathbf{G}$ & 700 & 80 & 1 & $E$ & A & $N$ & $\mathbf{R}$ & 5,552 & 3,331 \\
\hline 2,743 & $S$ & $\mathbf{G}$ & 700 & 80 & 1 & $E$ & A & $N$ & $\mathrm{R}$ & 5,704 & 3,422 \\
\hline 2,744 & $W$ & $\mathbf{G}$ & 700 & 80 & 1 & $E$ & $P$ & $\mathrm{~N}$ & $\mathrm{R}$ & 8,717 & 6,102 \\
\hline 2,745 & $S$ & $\mathbf{G}$ & 700 & 80 & 1 & $E$ & $P$ & $\mathrm{~N}$ & $R$ & 8,550 & 5,985 \\
\hline
\end{tabular}


Table A.5. Packaged Boilers (contd)

\begin{tabular}{|c|c|c|c|c|c|c|c|c|c|c|c|}
\hline REC & TYPE & FUEL & INPUT & EFF & $\mathrm{EXCH}$ & IGN & BURN & VENT & CTYPE & LCOST & CCOST \\
\hline 2,746 & $W$ & $\mathbf{G}$ & 750 & 83 & 1 & $E$ & $P$ & $N$ & $\mathbf{R}$ & 10,192 & 5,606 \\
\hline 2,747 & $w$ & G & 780 & 81 & 1 & $E$ & A & $\mathrm{N}$ & $\mathbf{R}$ & 6,970 & 5,506 \\
\hline 2,748 & $S$ & G & 780 & 81 & 1 & $E$ & A & $\mathbf{N}$ & $R$ & 7,168 & 5,663 \\
\hline 2,749 & $S$ & G & 790 & 82 & 1 & $E$ & $P$ & $Y$ & $\mathbf{R}$ & 7,575 & 5,303 \\
\hline 2,750 & $\bar{W}$ & G & 790 & 82 & 1 & $E$ & $\mathbf{P}$ & $Y$ & $\mathbf{R}$ & 7,575 & 5,303 \\
\hline 2,751 & $W$ & G & 800 & 80 & 1 & $E$ & A & $\mathbf{N}$ & $\mathbf{R}$ & 7,138 & 3,926 \\
\hline 2,752 & $S$ & G & 800 & 80 & 1 & $E$ & $A$ & $N$ & $\mathbf{R}$ & 7,421 & 4,082 \\
\hline 2,753 & $w$ & $\mathbf{G}$ & 800 & 80 & 1 & $P$ & $\bar{A}$ & $\mathbf{N}$ & $\mathbf{R}$ & 5,304 & 3,342 \\
\hline 2,754 & $\mathrm{~S}$ & $\mathbf{G}$ & 800 & 80 & 1 & $P$ & $A$ & $\mathrm{~N}$ & $R$ & 5,455 & 3,437 \\
\hline 2,755 & $W$ & $\mathbf{G}$ & 800 & 80 & 1 & $E$ & $A$ & $\mathrm{~N}$ & $\mathbf{R}$ & 6,175 & 3,705 \\
\hline 2,756 & $S$ & $\mathbf{G}$ & 800 & 80 & 1 & $E$ & A & $\mathrm{N}$ & $\mathrm{R}$ & 6,340 & 3,804 \\
\hline 2,757 & $W$ & $\mathbf{G}$ & 840 & 81 & 1 & $E$ & $P$ & $\mathrm{~N}$ & $\mathbf{R}$ & 9,220 & 6,454 \\
\hline 2,758 & $\mathrm{~S}$ & $G$ & 840 & 81 & 1 & $E$ & $P$ & $\mathrm{~N}$ & $\mathbf{R}$ & 9,274 & 6,492 \\
\hline 2,759 & $\mathrm{~W}$ & $\mathbf{G}$ & 860 & 83 & 1 & $E$ & $P$ & $\mathrm{~N}$ & $R$ & 10,828 & 5,955 \\
\hline 2,760 & $W$ & $\mathbf{G}$ & 900 & 83 & 1 & $E$ & $P$ & $N$ & $R$ & 11,040 & 6,072 \\
\hline 2,761 & $\bar{W}$ & $\mathbf{G}$ & 900 & 80 & 1 & $E$ & A & $\mathrm{N}$ & $\mathrm{R}$ & 7,660 & 4,213 \\
\hline 2,762 & $S$ & $\mathbf{G}$ & 900 & 80 & 1 & $E$ & A & $\mathrm{N}$ & $R$ & 7,943 & 4,369 \\
\hline 2,763 & $w$ & $G$ & 900 & 80 & 1 & $P$ & $A$ & $\mathrm{~N}$ & $\mathrm{R}$ & 6,315 & 3,978 \\
\hline 2,764 & $\mathrm{~S}$ & $\mathbf{G}$ & 900 & 80 & 1 & $P$ & A & $\mathrm{N}$ & $R$ & 6,477 & 4,081 \\
\hline 2,765 & $\bar{W}$ & $G$ & 900 & 80 & 1 & $E$ & $\bar{A}$ & $\mathrm{~N}$ & $\mathrm{R}$ & 6,641 & 3,985 \\
\hline 2,766 & $\mathrm{~S}$ & G & 900 & 80 & 1 & $E$ & A & $\mathrm{N}$ & $\mathrm{R}$ & 6,811 & 4,087 \\
\hline 2,767 & W & $\mathbf{G}$ & 910 & 81 & 1 & $E$ & A & $\mathrm{N}$ & $\mathrm{R}$ & 7,683 & 6,070 \\
\hline 2,768 & $S$ & $\mathbf{G}$ & 910 & 81 & 1 & $E$ & A & $\mathrm{N}$ & $R$ & 7,909 & 6,248 \\
\hline 2,769 & $\mathrm{~W}$ & $\mathbf{G}$ & 940 & 83 & $\mathrm{I}$ & $E$ & $P$ & $\mathrm{~N}$ & $R$ & 12,740 & 7,007 \\
\hline 2,770 & $\mathrm{~S}$ & $\mathbf{G}$ & 940 & 82 & 1 & $E$ & $P$ & $\mathrm{Y}$ & $\mathbf{R}$ & 8,233 & 5,763 \\
\hline 2,771 & $W$ & $\mathbf{G}$ & 940 & 82 & 1 & $E$ & $\bar{P}$ & $\bar{Y}$ & $R$ & 8,233 & 5,763 \\
\hline 2,772 & $S$ & $\mathbf{G}$ & 1,000 & 82 & 1 & $E$ & $P$ & $\mathrm{~N}$ & $\mathbf{R}$ & 9,840 & 6,888 \\
\hline 2,773 & $W$ & $\mathbf{G}$ & 1,000 & 82 & $\mathrm{I}$ & $E$ & $P$ & $\mathrm{~N}$ & $\mathrm{R}$ & 9,840 & 6,888 \\
\hline 2,774 & $W$ & $\mathbf{G}$ & 1,000 & 80 & 1 & $E$ & $A$ & $\mathbf{N}$ & $\mathrm{R}$ & 8,132 & 4,473 \\
\hline 2,775 & $S$ & $\mathbf{G}$ & 1,000 & 80 & 1 & $E$ & $A$ & $\mathbf{N}$ & $\mathrm{R}$ & 8,415 & 4,628 \\
\hline 2,776 & $w$ & G & 1,000 & 80 & 1 & $P$ & A & $N$ & $\mathbf{R}$ & 6,720 & 4,234 \\
\hline 2,777 & $S$ & $\mathbf{G}$ & 1,000 & 80 & 1 & $P$ & A & $\mathbf{N}$ & $R$ & 6,887 & 4,339 \\
\hline 2,778 & $W$ & G & 1,000 & 80 & 1 & $E$ & A & $\mathrm{N}$ & $\mathbf{R}$ & 7,115 & 4,269 \\
\hline 2,779 & $S$ & G & 1,010 & 82 & 1 & $E$ & $P$ & $\mathrm{~N}$ & $R$ & 9,840 & 6,888 \\
\hline 2,780 & $W$ & $\mathbf{G}$ & 1,010 & 82 & 1 & $E$ & $P$ & $\mathrm{~N}$ & $\mathbf{R}$ & 9,840 & 6,888 \\
\hline 2,781 & $W$ & G & 1,040 & 81 & 1 & $E$ & $\bar{A}$ & $\mathrm{~N}$ & $\bar{R}$ & 8,258 & 6,524 \\
\hline 2,782 & $\mathrm{~S}$ & $\mathbf{G}$ & 1,040 & 81 & 1 & $\bar{E}$ & A & $N$ & $\mathrm{R}$ & 8,484 & 6,702 \\
\hline 2,783 & $S$ & $\mathbf{G}$ & 1,080 & 82 & $I$ & $E$ & $P$ & $\bar{Y}$ & $\mathrm{R}$ & 9,124 & 6,387 \\
\hline 2,784 & $w$ & $\mathbf{G}$ & 1,080 & 82 & 1 & $E$ & $P$ & $Y$ & $\mathrm{R}$ & 9,124 & 6,387 \\
\hline 2,785 & $W$ & G & 1,090 & 83 & 1 & $E$ & $P$ & $\bar{N}$ & $\mathrm{R}$ & 13,588 & 7,473 \\
\hline 2,786 & $W$ & $\mathbf{G}$ & 1,100 & 80 & 1 & $E$ & $\mathrm{~A}$ & $\mathbf{N}$ & $R$ & 9,827 & 5,405 \\
\hline 2,787 & 5 & $G$ & 1,100 & 80 & 1 & $E$ & A & $\mathbf{N}$ & $R$ & 10,057 & 5,531 \\
\hline 2,788 & $\mathbf{W}$ & $G$ & 1,100 & 80 & 1 & $\mathbf{P}$ & $A$ & $\mathbf{N}$ & $\mathbf{R}$ & 7,125 & 4,489 \\
\hline 2,789 & $S$ & $\mathbf{G}$ & 1,100 & 80 & 1 & $P$ & $\mathrm{~A}$ & $\mathbf{N}$ & $R$ & 7,286 & 4,590 \\
\hline 2,790 & W & G & 1,100 & 80 & 1 & $E$ & A & $\mathbf{N}$ & $R$ & 8,237 & 4,942 \\
\hline
\end{tabular}


Table A.5. Packaged Boilers (contd)

\begin{tabular}{|c|c|c|c|c|c|c|c|c|c|c|c|}
\hline REC & TYPE & FUEL & INPUT & EFF & $\mathrm{EXCH}$ & $\mathrm{IGN}$ & BURN & VENT & CTYPE & LCOST & CCOST \\
\hline 2,791 & $S$ & $\mathbf{G}$ & 1,100 & 80 & 1 & $E$ & $A$ & $N$ & $R$ & 8,376 & 5,026 \\
\hline 2,792 & $W$ & $\mathbf{G}$ & 1,120 & 83 & 1 & $E$ & $P$ & $\mathrm{~N}$ & $\bar{R}$ & 15,288 & 8,408 \\
\hline 2,793 & $W$ & $\mathbf{G}$ & 1,170 & 81 & 1 & $E$ & $A$ & $\mathrm{~N}$ & $\mathbf{R}$ & 8,968 & 7,085 \\
\hline 2,794 & $\mathrm{~S}$ & $\mathbf{G}$ & 1,170 & 81 & I & $E$ & A & $\mathbf{N}$ & $\mathbf{R}$ & 9,163 & 7,239 \\
\hline 2,795 & $W$ & $\mathbf{G}$ & 1,200 & 80 & 1 & $\mathbf{E}$ & A & $\mathbf{N}$ & $R$ & 10,295 & 5,662 \\
\hline 2,796 & $S$ & $\mathbf{G}$ & 1,200 & 80 & 1 & $E$ & $A$ & $\mathrm{~N}$ & $\mathrm{R}$ & 10,523 & 5,788 \\
\hline 2,797 & W & $\mathbf{G}$ & 1,200 & 80 & 1 & $P$ & $A$ & $\mathbf{N}$ & $R$ & 7,554 & 4,759 \\
\hline 2,798 & $\mathbf{S}$ & $\mathbf{G}$ & 1,200 & 80 & 1 & $P$ & $\bar{A}$ & $\bar{N}$ & $\mathrm{R}$ & 7,696 & 4,848 \\
\hline 2,799 & $W$ & $G$ & 1,200 & 80 & $I$ & $E$ & $A$ & $\mathbf{N}$ & $R$ & 8,852 & 5,311 \\
\hline $2 ; 800$ & $\mathrm{~s}$ & G & 1,200 & 80 & 1 & $E$ & A & $N$ & $R$ & 8,991 & 5,395 \\
\hline 2,801 & $S$ & $\mathbf{G}$ & 1,230 & 82 & 1 & $E$ & $P$ & $\mathrm{Y}$ & $R$ & 9,650 & 6,755 \\
\hline 2,802 & $W$ & $G$ & 1,230 & 82 & 1 & $E$ & $P$ & $\bar{Y}$ & $R$ & 9,650 & 6,755 \\
\hline 2,803 & $W$ & $\mathbf{G}$ & 1,260 & 81 & 1 & $E$ & $P$ & $\mathbf{N}$ & $\mathbf{R}$ & 10,273 & 7,191 \\
\hline 2,804 & 5 & $\mathbf{G}$ & 1,260 & 81 & 1 & $E$ & $P$ & $\mathrm{~N}$ & $R$ & 10,333 & 7,233 \\
\hline 2,805 & $W$ & G & 1,300 & 80 & 1 & $E$ & $\bar{A}$ & $\mathbf{N}$ & $R$ & 11,052 & 6,079 \\
\hline 2,806 & $S$ & $\mathbf{G}$ & 1,300 & 80 & 1 & $E$ & A & $\mathrm{N}$ & $R$ & 11,312 & 6,222 \\
\hline 2,807 & $W$ & $G$ & 1,300 & 80 & 1 & $P$ & A & $\mathrm{N}$ & $\mathbf{R}$ & 8,562 & 5,394 \\
\hline 2,808 & $S$ & $\mathbf{G}$ & 1,300 & 80 & 1 & $P$ & A & $\mathrm{N}$ & $\mathbf{R}$ & 8,703 & 5,483 \\
\hline 2,809 & $\mathrm{~W}$ & G & 1,300 & 80 & 1 & $E$ & A & $\mathrm{N}$ & $R$ & 9,179 & 5,507 \\
\hline 2,810 & $S$ & G & 1,300 & 80 & 1 & $E$ & A & $\mathrm{N}$ & $\mathrm{R}$ & 9,318 & 5,591 \\
\hline 2,811 & $W$ & G & 1,300 & 81 & 1 & $E$ & A & $\mathrm{N}$ & $\mathbf{R}$ & 9,567 & 7,558 \\
\hline 2,812 & $\mathrm{~S}$ & G & 1,300 & 81 & 1 & $\bar{E}$ & A & $\mathrm{N}$ & $\mathbf{R}$ & 9,762 & 7,712 \\
\hline 2,813 & $W$ & $\mathbf{G}$ & 1,350 & 83 & 1 & $E$ & $P$ & $\mathrm{~N}$ & $\mathrm{R}$ & 16,560 & 9,108 \\
\hline 2,814 & $S$ & $\mathbf{G}$ & 1,360 & 82 & 1 & $E$ & $P$ & $\mathrm{~N}$ & $\mathbf{R}$ & 10,816 & 7,571 \\
\hline 2,815 & $\bar{W}$ & $\mathbf{G}$ & 1,360 & 82 & 1 & $\bar{E}$ & $P$ & $N$ & $\mathrm{R}$ & 10,816 & 7,571 \\
\hline 2,816 & $\mathrm{~S}$ & G & 1,380 & 82 & 1 & $E$ & $P$ & $\mathrm{Y}$ & $\mathbf{R}$ & 10,219 & 7,153 \\
\hline 2,817 & $\bar{W}$ & $G$ & 1,380 & 82 & 1 & $E$ & $P$ & $Y$ & $\mathbf{R}$ & 10,219 & 7,153 \\
\hline 2,818 & $W$ & $\mathbf{G}$ & 1,400 & 80 & 1 & $E$ & $\mathrm{~A}$ & $\mathrm{~N}$ & $\mathrm{R}$ & 11,524 & 6,338 \\
\hline 2,819 & $S$ & $\mathbf{G}$ & 1,400 & 80 & 1 & $E$ & $A$ & $N$ & $\mathrm{R}$ & 11,751 & 6,463 \\
\hline 2,820 & $W$ & $\mathbf{G}$ & 1,400 & 80 & 1 & $P$ & $\mathrm{~A}$ & $\mathrm{~N}$ & $\mathbf{R}$ & 8,976 & 5,655 \\
\hline 2,821 & $S$ & G & 1,400 & 80 & 1 & $P$ & $A$ & $\mathrm{~N}$ & $\mathbf{R}$ & 9,113 & 5,741 \\
\hline 2,822 & $W$ & $\mathbf{G}$ & 1,400 & 80 & 1 & $E$ & A & $\mathbf{N}$ & $\mathbf{R}$ & 9,795 & 5,877 \\
\hline 2,823 & $S$ & $\mathbf{G}$ & 1,400 & 80 & 1 & $E$ & $A$ & $\mathbf{N}$ & $\mathbf{R}$ & 9,934 & 5,960 \\
\hline 2,824 & $W$ & $\mathbf{G}$ & 1,430 & 81 & $T$ & $E$ & A & $\mathrm{N}$ & $\mathrm{R}$ & 10,149 & 8,018 \\
\hline 2,825 & $S$ & $G$ & 1,430 & 81 & 1 & $E$ & A & $\mathrm{N}$ & $\mathbf{R}$ & 10,344 & 8,172 \\
\hline 2,826 & $W$ & $\mathbf{G}$ & 1,500 & 80 & I & $E$ & A & $\mathbf{N}$ & $\mathrm{R}$ & 11,996 & 6,598 \\
\hline 2,827 & $\mathrm{~S}$ & $\mathbf{G}$ & 1,500 & 80 & 1 & $E$ & A & $\mathrm{N}$ & $R$ & 12,241 & 6,733 \\
\hline 2,828 & $W$ & $\mathbf{G}$ & 1,500 & 80 & 1 & $P$ & A & $\mathbf{N}$ & $R$ & 9,374 & 5,906 \\
\hline 2,829 & $\mathrm{~S}$ & $\mathbf{G}$ & 1,500 & 80 & 1 & $P$ & A & $N$ & $\mathrm{R}$ & 9,526 & 6,001 \\
\hline 2,830 & $W$ & $\mathbf{G}$ & 1,500 & 80 & 1 & $E$ & A & $\mathbf{N}$ & $\mathrm{R}$ & 10,268 & 6,161 \\
\hline 2,831 & $S$ & $\mathbf{G}$ & 1,500 & 80 & 1 & $E$ & A & $\mathbf{N}$ & $\mathrm{R}$ & 10,417 & 6,250 \\
\hline 2,832 & $S$ & $\mathbf{G}$ & 1,530 & 82 & $\mathrm{I}$ & $E$ & $P$ & $\bar{Y}$ & $\mathrm{R}$ & 10,838 & 7,587 \\
\hline 2,833 & $W$ & $\mathbf{G}$ & 1,530 & 82 & 1 & $E$ & $P$ & $Y$ & $R$ & 10,838 & 7,587 \\
\hline 2,834 & $W$ & $G$ & 1,560 & 81 & 1 & $E$ & A & $\mathrm{N}$ & $\mathrm{R}$ & 10,937 & 8,640 \\
\hline 2,835 & $S$ & $\mathbf{G}$ & 1,560 & 81 & 1 & $E$ & A & $\mathrm{N}$ & $\mathrm{R}$ & 11,189 & 8,839 \\
\hline
\end{tabular}


Table A.5. Packaged Boilers (contd)

\begin{tabular}{|c|c|c|c|c|c|c|c|c|c|c|c|}
\hline REC & TYPE & FUEL & INPUT & EFF & $\mathrm{EXCH}$ & IGN & BURN & VENT & CTYPE & LCOST & CCOST \\
\hline 2,836 & $W$ & G & 1,600 & 80 & 1 & $E$ & A & $\mathrm{N}$ & $\mathbf{R}$ & 13,662 & 7,514 \\
\hline 2,837 & $\mathrm{~s}$ & $\mathbf{G}$ & 1,600 & 80 & $\mathrm{~T}$ & $E$ & $A$ & $\mathrm{~N}$ & $\mathbf{R}$ & 13,842 & 7,613 \\
\hline 2,838 & $w$ & $\mathbf{G}$ & 1,600 & 80 & 1 & $P$ & $A$ & $\mathrm{~N}$ & $\mathrm{R}$ & 9,782 & 6,163 \\
\hline 2,839 & $S$ & $\mathbf{G}$ & 1,600 & 80 & $T$ & $P$ & $\bar{A}$ & $\bar{N}$ & $\mathrm{R}$ & 9,934 & 6,258 \\
\hline 2,840 & $W$ & $\mathbf{G}$ & 1,600 & 80 & 1 & $E$ & A & $\mathrm{N}$ & $R$ & 11,578 & 6,947 \\
\hline 2,841 & $\mathrm{~S}$ & $\mathbf{G}$ & 1,600 & 80 & I & $E$ & $A$ & $N$ & $R$ & 11,694 & 7,016 \\
\hline 2,842 & $\mathrm{~S}$ & $\mathbf{G}$ & 1,670 & 82 & 1 & $E$ & $P$ & $Y$ & $\mathrm{R}$ & 11,458 & 8,021 \\
\hline 2,843 & $\mathbf{W}$ & $G$ & 1,670 & 82 & $T$ & $E$ & $\mathbf{P}$ & $\bar{Y}$ & $\mathrm{R}$ & 11,458 & 8,021 \\
\hline 2,844 & $W$ & $G$ & 1,680 & 81 & 1 & $E$ & $\mathrm{P}$ & $\mathbf{N}$ & $\bar{R}$ & 12,449 & 8,714 \\
\hline 2,845 & $\mathrm{~s}$ & $\bar{G}$ & 1,680 & 81 & 1 & $E$ & $P$ & $\bar{N}$ & $\mathrm{R}$ & 12,494 & 8,746 \\
\hline 2,846 & $W$ & $G$ & 1,690 & 81 & 1 & $E$ & $\bar{A}$ & $\bar{N}$ & $\mathbf{R}$ & 11,561 & 9,133 \\
\hline 2,847 & $S$ & $\mathbf{G}$ & 1,690 & 81 & 1 & $\mathrm{E}$ & $A$ & $\mathbf{N}$ & $R$ & 11,754 & 9,286 \\
\hline 2,848 & $\bar{W}$ & G & 1,700 & 80 & 1 & $E$ & A & $\mathbf{N}$ & $\mathrm{R}$ & 14,132 & 7,773 \\
\hline 2,849 & $\mathrm{~s}$ & $G$ & 1,700 & 80 & 1 & $E$ & A & $N$ & $\mathrm{R}$ & 14,312 & 7,872 \\
\hline 2,850 & W & G & 1,700 & 80 & 1 & $P$ & A & $\bar{N}$ & $\mathbf{R}$ & 10,821 & 6,817 \\
\hline 2,851 & $S$ & $G$ & 1,700 & 80 & 1 & $P$ & A & $\mathrm{N}$ & $R$ & 10,945 & 6,895 \\
\hline 2,852 & $W$ & G & 1,700 & 80 & 1 & $\bar{E}$ & $\bar{A}$ & $\bar{N}$ & $R$ & 11,913 & 7,148 \\
\hline 2,853 & $S$ & G & 1,700 & 80 & 1 & $E$ & A & $N$ & $\mathbf{R}$ & 12,029 & 7,217 \\
\hline 2,854 & $S$ & $\mathbf{G}$ & 1,700 & 81 & I & $E$ & $P$ & $\mathbf{N}$ & $R$ & 12,357 & 8,650 \\
\hline 2,855 & $w$ & $\mathbf{G}$ & 1,700 & 81 & 1 & $E$ & $P$ & $\bar{N}$ & $\mathbf{R}$ & 12,357 & 8,650 \\
\hline 2,856 & $w$ & $\mathbf{G}$ & 1,800 & 80 & $I$ & $E$ & $\mathrm{~A}$ & $\mathrm{~N}$ & $\mathrm{R}$ & 14,605 & 8,033 \\
\hline 2,857 & $\mathrm{~S}$ & G & 1,800 & 80 & 1 & $E$ & A & $N$ & $\mathrm{R}$ & 14,783 & 8,131 \\
\hline 2,858 & $W$ & $\mathbf{G}$ & 1,800 & 80 & 1 & $P$ & A & $\mathrm{N}$ & $\mathrm{R}$ & 11,230 & 7,075 \\
\hline 2,859 & $S$ & $\mathbf{G}$ & 1,800 & 80 & 1 & $P$ & $\bar{A}$ & $\mathrm{~N}$ & $\mathbf{R}$ & 11,351 & 7,151 \\
\hline 2,860 & $\bar{W}$ & $\mathbf{G}$ & 1,800 & 80 & 1 & $E$ & A & $\mathbf{N}$ & $\mathbf{R}$ & 12,528 & 7,517 \\
\hline 2,861 & $S$ & $\mathbf{G}$ & 1,800 & 80 & 1 & $E$ & A & $\mathbf{N}$ & $\mathrm{R}$ & 12,644 & 7,586 \\
\hline 2,862 & $w$ & $\mathbf{G}$ & 1,900 & 80 & 1 & $E$ & $A$ & $\bar{N}$ & $\mathbf{R}$ & 15,076 & 8,292 \\
\hline 2,863 & $S$ & $\mathbf{G}$ & 1,900 & 80 & 1 & $\bar{E}$ & A & $\mathrm{N}$ & $R$ & 15,256 & 8,391 \\
\hline 2,864 & $W$ & $\mathbf{G}$ & 1,900 & 80 & 1 & $P$ & A & $\mathrm{N}$ & $\mathrm{R}$ & 11,629 & 7,326 \\
\hline 2,865 & $S$ & $\mathbf{G}$ & 1,900 & 80 & 1 & $P$ & A & $\mathrm{N}$ & $R$ & 11,752 & 7,404 \\
\hline 2,866 & $W$ & $\mathbf{G}$ & 1,900 & 80 & I & $E$ & A & $\mathrm{N}$ & $\mathbf{R}$ & 12,999 & 7,799 \\
\hline 2,867 & $\mathrm{~S}$ & $G$ & 1,900 & 80 & I & $\bar{E}$ & A & $\mathrm{N}$ & $R$ & 13,115 & 7,869 \\
\hline 2,868 & $W$ & $G$ & 1,960 & 80 & I & $E$ & $P$ & $\bar{N}$ & $\mathbf{R}$ & 13,177 & 9,224 \\
\hline 2,869 & $\mathrm{~S}$ & G & 1,960 & 80 & 1 & $E$ & $P$ & $\mathrm{~N}$ & $\mathrm{R}$ & 13,231 & 9,262 \\
\hline 2,870 & $W$ & $\mathbf{G}$ & 2,000 & 80 & I & $E$ & A & $\mathbf{N}$ & $\bar{R}$ & 15,546 & 8,550 \\
\hline 2,871 & $S$ & $G$ & 2,000 & 80 & 1 & $E$ & A & $\mathbf{N}$ & $\mathrm{R}$ & 15,726 & 8,649 \\
\hline 2,872 & $W$ & $G$ & 2,000 & 80 & 1 & $\bar{P}$ & A & $\mathbf{N}$ & $R$ & 12,041 & 7,586 \\
\hline 2,873 & $\mathrm{~s}$ & G & 2,000 & 80 & $i$ & $P$ & A & $\mathrm{N}$ & $\mathrm{R}$ & 12,458 & 7,849 \\
\hline 2,874 & $\mathbf{W}$ & $\mathbf{G}$ & 2,000 & 80 & 1 & $E$ & A & $\mathbf{N}$ & $R$ & 13,473 & 8,084 \\
\hline 2,875 & $\mathrm{~S}$ & $G$ & 2,000 & 80 & 1 & $E$ & $\mathrm{~A}$ & $\mathrm{~N}$ & $R$ & 13,589 & 8,153 \\
\hline 2,876 & $S$ & G & 2,050 & 81 & 1 & $E$ & $P$ & $\mathbf{N}$ & $\mathrm{R}$ & 13,922 & 9,745 \\
\hline 2,877 & W & $\mathbf{G}$ & 2,050 & 81 & 1 & $E$ & $P$ & $\mathbf{N}$ & $\mathrm{R}$ & 13,922 & 9,745 \\
\hline 2,878 & $\mathrm{~W}$ & $G$ & 2,100 & 80 & 1 & $E$ & $A$ & $\mathbf{N}$ & $R$ & 17,265 & 9,496 \\
\hline 2,879 & $S$ & $\mathbf{G}$ & 2,100 & 80 & 1 & $E$ & $\mathrm{~A}$ & $\mathrm{~N}$ & $\mathrm{R}$ & 17,445 & 9,595 \\
\hline 2,880 & W & $\mathbf{G}$ & 2,100 & 80 & 1 & $\bar{P}$ & A & $\mathrm{N}$ & $R$ & 13,046 & 8,219 \\
\hline
\end{tabular}


Table A.5. Packaged Boilers (contd)

\begin{tabular}{|c|c|c|c|c|c|c|c|c|c|c|c|}
\hline REC & TYPE & FUEL & INPUT & EFF & EXCH & IGN & BURN & VENT & CTYPE & LCOST & CCOST \\
\hline 2,881 & $\mathrm{~S}$ & $G$ & 2,100 & 80 & 1 & $P$ & $A$ & $\mathbf{N}$ & $R$ & 13,462 & 8,481 \\
\hline 2,882 & $w$ & $\mathbf{G}$ & 2,100 & 80 & 1 & $\bar{E}$ & $\bar{A}$ & $N$ & $R$ & 14,420 & 8,652 \\
\hline 2,883 & $\mathrm{~S}$ & $\mathbf{G}$ & 2,100 & 80 & 1 & $E$ & $A$ & $\mathbf{N}$ & $R$ & 14,536 & 8,722 \\
\hline 2,884 & $W$ & $\mathbf{G}$ & 2,200 & 80 & $\mathrm{I}$ & $\bar{E}$ & $\bar{A}$ & $\mathrm{~N}$ & $R$ & 17,739 & 9,756 \\
\hline 2,885 & $S$ & $\mathbf{G}$ & 2,200 & 80 & I & $E$ & A & $\mathbf{N}$ & $\mathbf{R}$ & 17,918 & 9,855 \\
\hline 2,886 & W & $\mathbf{G}$ & 2,200 & 80 & I & $\bar{P}$ & A & $N$ & $R$ & 13,458 & 8,479 \\
\hline 2,887 & $S$ & $\mathbf{G}$ & 2,200 & 80 & 1 & $P$ & $A$ & $\mathbf{N}$ & $R$ & 13,871 & 8,739 \\
\hline 2,888 & $W$ & $\mathbf{G}$ & 2,200 & 80 & 1 & $E$ & A & $\mathrm{N}$ & $R$ & 15,180 & 9,108 \\
\hline 2,889 & $S$ & $\mathbf{G}$ & 2,200 & 80 & 1 & $E$ & $A$ & $\mathbf{N}$ & $\mathrm{R}$ & 15,295 & 9,177 \\
\hline 2,890 & $\bar{W}$ & $\mathbf{G}$ & 2,300 & 80 & 1 & $\bar{E}$ & A & $\mathrm{N}$ & $R$ & 18,209 & 10,015 \\
\hline 2,891 & $\mathrm{~S}$ & G & 2,300 & 80 & 1 & $\bar{E}$ & $A$ & $N$ & $R$ & 18,388 & 10,113 \\
\hline 2,892 & $W$ & $\mathbf{G}$ & 2,300 & 80 & 1 & $\mathbf{P}$ & A & $\mathbf{N}$ & $R$ & 13,850 & 8,726 \\
\hline 2,893 & $\mathrm{~S}$ & $\mathbf{G}$ & 2,300 & 80 & 1 & $P$ & $\mathrm{~A}$ & $\mathbf{N}$ & $\mathrm{R}$ & 14,276 & 8,994 \\
\hline 2,894 & $w$ & $G$ & 2,300 & 80 & 1 & $E$ & $A$ & $\mathbf{N}$ & $R$ & 15,651 & 9,391 \\
\hline 2,895 & $\mathrm{~S}$ & $\mathbf{G}$ & 2,300 & 80 & 1 & $E$ & A & $N$ & $R$ & 15,766 & 9,460 \\
\hline 2,896 & $S$ & G & 2,400 & 81 & 1 & $E$ & $P$ & $\mathrm{~N}$ & $R$ & 15,214 & 10,650 \\
\hline 2,897 & $W$ & $\mathbf{G}$ & 2,400 & 81 & 1 & $E$ & $P$ & $\mathrm{~N}$ & $\mathbf{R}$ & 15,214 & 10,650 \\
\hline 2,898 & W & $\mathbf{G}$ & 2,400 & 80 & 1 & $\bar{E}$ & $\bar{A}$ & $N$ & $\mathbf{R}$ & 18,680 & 10,274 \\
\hline 2,899 & $\mathbf{S}$ & $G$ & 2,400 & 80 & $\mathrm{I}$ & $E$ & $A$ & $N$ & $\mathrm{R}$ & 18,859 & 10,372 \\
\hline 2,900 & W & G & 2,400 & 80 & 1 & $\bar{P}$ & A & $\mathbf{N}$ & $R$ & 14,267 & 8,988 \\
\hline 2,901 & $\mathrm{~S}$ & $\mathbf{G}$ & 2,400 & 80 & 1 & $P$ & $\bar{A}$ & $\mathrm{~N}$ & $\mathbf{R}$ & 14,732 & 9,281 \\
\hline 2,902 & $\bar{W}$ & $\mathbf{G}$ & 2,400 & 80 & 1 & $E$ & $A$ & $N$ & $R$ & 16,122 & 9,673 \\
\hline 2,903 & $S$ & $\mathbf{G}$ & 2,400 & 80 & 1 & $E$ & $A$ & $\mathbf{N}$ & $\mathrm{R}$ & 16,238 & 9,743 \\
\hline 2,904 & $S$ & $\mathbf{G}$ & 2,480 & 81 & 1 & $\overline{\mathrm{E}}$ & $P$ & $\mathbf{N}$ & $R$ & 16,355 & 11,449 \\
\hline 2,905 & $W$ & $\mathbf{G}$ & 2,480 & 81 & I & $\bar{E}$ & $P$ & $\mathbf{N}$ & $\mathrm{R}$ & 16,355 & 11,449 \\
\hline 2,906 & $W$ & $\mathbf{G}$ & 2,500 & 80 & 1 & $\bar{E}$ & A & $N$ & $R$ & 19,151 & 10,533 \\
\hline 2,907 & $S$ & $G$ & 2,500 & 80 & 1 & $\bar{E}$ & A & $\mathrm{N}$ & $\mathbf{R}$ & 19,412 & 10,677 \\
\hline 2,908 & $\bar{W}$ & $G$ & 2,500 & 80 & 1 & $\bar{P}$ & A & $\bar{N}$ & $R$ & 15,277 & 9,625 \\
\hline 2,909 & $S$ & $G$ & 2,500 & 80 & 1 & $P$ & $A$ & $N$ & $R$ & 15,740 & 9,916 \\
\hline 2,910 & $W$ & $\mathbf{G}$ & 2,500 & 80 & 1 & $E$ & A & $\mathrm{N}$ & $\mathrm{R}$ & 16,593 & 9,956 \\
\hline 2,911 & $S$ & G & 2,500 & 80 & 1 & $\bar{E}$ & A & $N$ & $R$ & 16,760 & 10,056 \\
\hline 2,912 & $W$ & $\mathbf{G}$ & 2,520 & 82 & 1 & E & $P$ & $\mathrm{~N}$ & $R$ & 16,986 & 11,890 \\
\hline 2,913 & $S$ & $\mathbf{G}$ & 2,520 & 82 & 1 & $\bar{E}$ & $P$ & $N$ & $\mathbf{R}$ & 17,148 & 12,004 \\
\hline 2,914 & $S$ & $\mathbf{G}$ & 2,540 & 81 & 1 & E & $\mathrm{P}$ & $N$ & $R$ & 24,651 & 17,256 \\
\hline 2,915 & $w$ & $\mathbf{G}$ & 2,540 & 81 & 1 & $\bar{E}$ & $\bar{P}$ & $\bar{N}$ & $\mathrm{R}$ & 24,651 & 17,256 \\
\hline 2,916 & $W$ & $\mathbf{G}$ & 2,600 & 80 & 1 & $\bar{E}$ & A & $N$ & $\mathrm{R}$ & 20,749 & 11,412 \\
\hline 2,917 & $S$ & $\mathbf{G}$ & 2,600 & 80 & I & $\bar{E}$ & A & $\overline{\mathrm{N}}$ & $R$ & 21,012 & 11,557 \\
\hline 2,918 & $\bar{W}$ & $\mathbf{G}$ & 2,600 & 80 & 1 & $\bar{E}$ & A & $N$ & $R$ & 17,576 & 10,546 \\
\hline 2,919 & $S$ & $\mathbf{G}$ & 2,600 & 80 & I & $\bar{E}$ & $A$ & $N$ & $\mathrm{R}$ & 17,743 & 10,646 \\
\hline 2,920 & $\mathrm{~W}$ & $G$ & 2,700 & 80 & 1 & $E$ & $A$ & $N$ & $\mathrm{R}$ & 21,223 & 11,673 \\
\hline 2,921 & $\mathrm{~s}$ & $G$ & 2,700 & 80 & 1 & E & A & $\mathrm{N}$ & $\mathrm{R}$ & 21,485 & 11,817 \\
\hline 2,922 & $W$ & $\mathbf{G}$ & 2,700 & 80 & 1 & $\bar{E}$ & A & $N$ & $R$ & 18,114 & 10,868 \\
\hline 2,923 & $S$ & $G$ & 2,700 & 80 & I & $\bar{E}$ & $A$ & $N$ & $\mathrm{R}$ & 18,359 & 11,015 \\
\hline 2,924 & $\mathrm{~S}$ & $\mathbf{G}$ & 2,710 & 81 & I & $\bar{E}$ & $\mathrm{P}$ & $N$ & $R$ & 16,754 & 11,728 \\
\hline 2,925 & $W$ & $\mathbf{G}$ & 2,710 & 81 & 1 & $\bar{E}$ & P & $\mathrm{N}$ & $\mathrm{R}$ & 16,754 & 11,728 \\
\hline
\end{tabular}


Table A.5. Packaged Boilers (contd)

\begin{tabular}{|c|c|c|c|c|c|c|c|c|c|c|c|}
\hline REC & TYPE & FUEL & INPUT & $\overline{E F F}$ & $\mathrm{EXCH}$ & IGN & BURN & VENT & CTYPE & LCOST & CCOST \\
\hline 2,926 & $W$ & $\mathbf{G}$ & 2,800 & 80 & 1 & $E$ & $A$ & $\mathbf{N}$ & $R$ & 21,694 & 11,932 \\
\hline 2,927 & S & G & 2,800 & 80 & 1 & $E$ & A & $\mathbf{N}$ & $R$ & 21,957 & 12,076 \\
\hline 2,928 & $W$ & $G$ & 2,800 & 80 & 1 & $E$ & $\bar{A}$ & $\bar{N}$ & $\mathbf{R}$ & 18,807 & 11,284 \\
\hline 2,929 & $S$ & $\mathbf{G}$ & 2,800 & 80 & I & $E$ & $A$ & $\mathbf{N}$ & $\mathrm{R}$ & 18,974 & 11,384 \\
\hline 2,930 & $S$ & G & 2,890 & 81 & I & $E$ & $\mathbf{P}$ & $\mathbf{N}$ & $\mathrm{R}$ & 17,913 & 12,539 \\
\hline 2,931 & $W$ & $G$ & 2,890 & 81 & I & $E$ & $P$ & $\mathrm{~N}$ & $\mathrm{R}$ & 17,913 & 12,539 \\
\hline 2,932 & $\mathrm{~S}$ & $\mathbf{G}$ & 2,890 & 81 & 1 & $\mathrm{E}$ & $\mathbf{P}$ & $\bar{N}$ & $R$ & 26,586 & 18,610 \\
\hline 2,933 & $\mathbf{W}$ & $\mathbf{G}$ & 2,890 & 81 & I & $E$ & $\mathbf{P}$ & $N$ & $\mathrm{R}$ & 26,586 & 18,610 \\
\hline 2,934 & $W$ & G & 2,900 & 80 & 1 & $E$ & $A$ & $\bar{N}$ & $R$ & 22,166 & 12,191 \\
\hline 2,935 & $\mathrm{~S}$ & $G$ & 2,900 & 80 & 1 & $E$ & A & $\mathrm{N}$ & $R$ & 22,427 & 12,335 \\
\hline 2,936 & $w$ & $G$ & 2,900 & 80 & I & $E$ & $A$ & $\mathrm{~N}$ & $\mathrm{R}$ & 19,278 & 11,567 \\
\hline 2,937 & $\mathrm{~S}$ & $\mathbf{G}$ & 2,900 & 80 & I & $E$ & $\bar{A}$ & $\mathbf{N}$ & $\mathbf{R}$ & 19,445 & 11,667 \\
\hline 2,938 & $W$ & $G$ & 3,000 & 80 & 1 & $E$ & $A$ & $N$ & $\mathrm{R}$ & 22,636 & 12,450 \\
\hline 2,939 & $\mathrm{~S}$ & $G$ & 3,000 & 80 & I & $E$ & $\bar{A}$ & $\mathbf{N}$ & $R$ & 22,898 & 12,594 \\
\hline 2,940 & $\mathrm{~W}$ & $\mathbf{G}$ & 3,000 & 80 & 1 & $E$ & $A$ & $\mathrm{~N}$ & $R$ & 19,749 & 11,849 \\
\hline 2,941 & $\mathrm{~S}$ & G & 3,000 & 80 & 1 & $E$ & A & $\mathbf{N}$ & $\mathrm{R}$ & 19,916 & 11,950 \\
\hline 2,942 & $S$ & $G$ & 3,100 & 81 & 1 & $E$ & $\mathbf{P}$ & $\mathrm{N}$ & $\mathrm{R}$ & 17,940 & 12,558 \\
\hline 2,943 & $\bar{W}$ & G & 3,100 & 81 & 1 & $E$ & $P$ & $\bar{N}$ & $R$ & 17,940 & 12,558 \\
\hline 2,944 & $\mathrm{~S}$ & $\mathbf{G}$ & 3,250 & 81 & 1 & $E$ & $P$ & $\mathbf{N}$ & $R$ & 28,403 & 19,882 \\
\hline 2,945 & $\mathbf{W}$ & $\mathbf{G}$ & 3,250 & 81 & 1 & $E$ & $P$ & $\mathbf{N}$ & $\bar{R}$ & 28,403 & 19,882 \\
\hline 2,946 & $\mathrm{~S}$ & G & 3,390 & 81 & 1 & $E$ & $P$ & $\bar{N}$ & $R$ & 19,431 & 13,602 \\
\hline 2,947 & $\mathrm{~W}$ & G & 3,390 & 81 & 1 & $E$ & $P$ & $N$ & $R$ & 19,431 & 13,602 \\
\hline 2,948 & $\mathrm{~s}$ & G & 3,610 & 81 & 1 & $E$ & $P$ & $N$ & $R$ & 30,225 & 21,158 \\
\hline 2,949 & $\bar{W}$ & $\mathbf{G}$ & 3,610 & 81 & 1 & $E$ & $P$ & $\mathrm{~N}$ & $R$ & 30,225 & 21,158 \\
\hline 2,950 & $\mathrm{~S}$ & $\mathbf{G}$ & 3,750 & 81 & 1 & $\bar{E}$ & $P$ & $\mathrm{~N}$ & $R$ & 20,620 & 14,434 \\
\hline 2,951 & $\mathbf{W}$ & $\mathbf{G}$ & 3,750 & 81 & 1 & $E$ & $P$ & $\mathrm{~N}$ & $\mathbf{R}$ & 20,620 & 14,434 \\
\hline 2,952 & $\mathrm{~S}$ & $\mathbf{G}$ & 3,970 & 81 & 1 & $E$ & $P$ & $\mathbf{N}$ & $\mathrm{R}$ & 32,094 & 22,466 \\
\hline 2,953 & $W$ & $\mathbf{G}$ & 3,970 & 81 & 1 & $E$ & $P$ & $N$ & $\mathrm{R}$ & 32,094 & 22,466 \\
\hline 2,954 & $S$ & $\mathbf{G}$ & 4,110 & 81 & 1 & $E$ & $P$ & $\bar{N}$ & $R$ & 21,944 & 15,361 \\
\hline 2,955 & $\mathbf{W}$ & $\mathbf{G}$ & 4,110 & 81 & 1 & $E$ & $P$ & $\mathrm{~N}$ & $R$ & 21,944 & 15,361 \\
\hline 2,956 & $\mathrm{~S}$ & $\mathbf{G}$ & 4,330 & 81 & $T$ & $E$ & $P$ & $\mathbf{N}$ & $\mathbf{R}$ & 33,914 & 23,740 \\
\hline 2,957 & $W$ & $\mathbf{G}$ & 4,330 & 81 & 1 & $E$ & $P$ & $\bar{N}$ & $R$ & 33,914 & 23,740 \\
\hline 2,958 & $\mathrm{~S}$ & $\mathbf{G}$ & 4,470 & 81 & 1 & $E$ & $P$ & $\bar{N}$ & $\mathbf{R}$ & 23,031 & 16,122 \\
\hline 2,959 & $W$ & $\mathbf{G}$ & 4,470 & 81 & 1 & $E$ & $P$ & $N$ & $R$ & 23,031 & 16,122 \\
\hline 2,960 & $S$ & $\mathbf{G}$ & 4,690 & 81 & 1 & $E$ & $P$ & $\mathbf{N}$ & $\mathrm{R}$ & 36,084 & 25,259 \\
\hline 2,961 & $w$ & $\mathbf{G}$ & 4,690 & 81 & 1 & $E$ & $P$ & $\mathbf{N}$ & $\mathbf{R}$ & 36,084 & 25,259 \\
\hline 2,962 & S & $\mathbf{G}$ & 4,760 & 81 & $T$ & $E$ & $P$ & $\mathbf{N}$ & $\mathbf{R}$ & 24,122 & 16,885 \\
\hline 2,963 & $\bar{W}$ & $\mathbf{G}$ & 4,760 & 81 & 1 & $E$ & $P$ & $N$ & $\mathbf{R}$ & 24,122 & 16,885 \\
\hline 2,964 & $\mathrm{~S}$ & $\mathbf{G}$ & 4,980 & 81 & 1 & $E$ & $P$ & $\mathbf{N}$ & $R$ & 25,267 & 17,687 \\
\hline 2,965 & $W$ & $\mathbf{G}$ & 4,980 & 81 & 1 & $\bar{E}$ & $P$ & $N$ & $\mathrm{R}$ & 25,267 & 17,687 \\
\hline 2,966 & $\mathrm{~S}$ & $\mathbf{G}$ & 5,050 & 82 & 1 & $E$ & $P$ & $\mathbf{N}$ & $R$ & 37,747 & 26,423 \\
\hline 2,967 & $\bar{W}$ & $\mathbf{G}$ & 5,050 & 82 & 1 & $E$ & $P$ & $N$ & $\mathrm{R}$ & 37,747 & 26,423 \\
\hline 2,968 & $S$ & $\mathbf{G}$ & 5,120 & 81 & 1 & $E$ & $P$ & $\bar{N}$ & $\mathbf{R}$ & 25,378 & 17,765 \\
\hline 2,969 & $\mathbf{W}$ & $\mathbf{G}$ & 5,120 & 81 & 1 & $E$ & $P$ & $\mathrm{~N}$ & $\mathbf{R}$ & 25,378 & 17,765 \\
\hline 2,970 & $S$ & $G$ & 5,410 & 82 & 1 & $\bar{E}$ & $P$ & $\mathrm{~N}$ & $\mathrm{R}$ & 39,377 & 27,564 \\
\hline
\end{tabular}


Table A.5. Packaged Boilers (contd)

\begin{tabular}{|c|c|c|c|c|c|c|c|c|c|c|c|}
\hline REC & TYPE & FUEL & INPUT & EFF & EXCH & IGN & BURN & VENT & CTYPE & LCOST & CCOST \\
\hline 2,971 & $W$ & $\mathbf{G}$ & 5,410 & 82 & 1 & $\mathbf{E}$ & $P$ & $N$ & $\mathbf{R}$ & 39,377 & 27,564 \\
\hline 2,972 & $S$ & $\mathbf{G}$ & 5,490 & 81 & 1 & $E$ & $\mathbf{P}$ & $N$ & $\mathbf{R}$ & 26,951 & 18,866 \\
\hline 2,973 & $W$ & $\mathbf{G}$ & 5,490 & 81 & 1 & $E$ & $P$ & $\mathbf{N}$ & $\mathbf{R}$ & 26,951 & 18,866 \\
\hline 2,974 & $S$ & $\mathbf{G}$ & 5,770 & 82 & 1 & $E$ & $\bar{P}$ & $N$ & $\mathbf{R}$ & 40,864 & 28,605 \\
\hline 2,975 & $W$ & $\mathbf{G}$ & 5,770 & 82 & 1 & $E$ & $\mathbf{P}$ & $N$ & $R$ & 40,864 & 28,605 \\
\hline 2,976 & $S$ & $\mathbf{G}$ & 5,850 & 81 & .1 & $E$ & $\mathbf{P}$ & $\mathbf{N}$ & $\mathbf{R}$ & 28,041 & 19,629 \\
\hline 2,977 & $W$ & $\mathbf{G}$ & 5,850 & 81 & 1 & $E$ & $\mathbf{P}$ & $\mathbf{N}$ & $\mathbf{R}$ & 28,041 & 19,629 \\
\hline 2,978 & $S$ & $\mathbf{G}$ & 6,130 & 82 & $I$ & $E$ & $\mathbf{P}$ & $N$ & $R$ & 42,456 & 29,719 \\
\hline 2,979 & $W$ & $G$ & 6,130 & 82 & 1 & $\bar{E}$ & $P$ & $\bar{N}$ & $R$ & 42,456 & 29,719 \\
\hline 2,980 & $S$ & $\mathbf{G}$ & 6,500 & 82 & I & $\bar{E}$ & $P$ & $\mathbf{N}$ & $\mathbf{R}$ & 44,699 & 31,289 \\
\hline 2,981 & $W$ & $\mathbf{G}$ & 6,500 & 82 & 1 & $\bar{E}$ & $P$ & $\mathrm{~N}$ & $\mathbf{R}$ & 44,699 & 31,289 \\
\hline 2,982 & $\mathrm{~s}$ & $\mathbf{G}$ & 6,860 & 82 & 1 & $E$ & $P$ & $\mathbf{N}$ & $\mathbf{R}$ & 46,604 & 32,623 \\
\hline 2,983 & $\mathbf{W}$ & $\mathbf{G}$ & 6,860 & 82 & I & $E$ & $P$ & $N$ & $\mathbf{R}$ & 46,604 & 32,623 \\
\hline 2,984 & $\mathrm{~S}$ & $\mathbf{G}$ & 7,220 & 82 & 1 & $E$ & $P$ & $\mathrm{~N}$ & $R$ & 47,570 & 33,299 \\
\hline 2,985 & $W$ & $\mathbf{G}$ & 7,220 & 82 & 1 & $E$ & $P$ & $N$ & $R$ & 47,570 & 33,299 \\
\hline 2,986 & $W$ & $\mathbf{G}$ & 250 & 88 & $\mathrm{~N}$ & $E$ & $P$ & $\mathrm{~N}$ & $R$ & 6,627 & 4,374 \\
\hline 2,987 & W & $\mathbf{G}$ & 300 & 96 & $\mathbf{N}$ & $S$ & $L$ & & $R$ & 6,500 & 5,850 \\
\hline 2,988 & W & $\mathbf{G}$ & 500 & 88 & $N$ & $E$ & $P$ & $\mathrm{~N}$ & $R$ & 8,954 & 5,910 \\
\hline 2,989 & $W$ & $G$ & 500 & 95 & $\mathrm{~N}$ & $\mathrm{~S}$ & L & & $R$ & 7,895 & 7,106 \\
\hline 2,990 & $S$ & $\mathbf{G}$ & 500 & 87 & $\mathbf{N}$ & $S$ & $L$ & & $\mathbf{R}$ & 9,450 & 8,505 \\
\hline 2,991 & $\bar{W}$ & $\mathbf{G}$ & 750 & 88 & $N$ & $E$ & $P$ & $\mathbf{N}$ & $\mathbf{R}$ & 9,891 & 6,528 \\
\hline 2,992 & $W$ & $\mathbf{G}$ & 750 & 94 & $\mathbf{N}$ & $s$ & $L$ & & $\mathbf{R}$ & 8,925 & 8,033 \\
\hline 2,993 & $\mathrm{~s}$ & $\mathbf{G}$ & 750 & 87 & $\mathrm{~N}$ & $S$ & L & & $\mathrm{R}$ & 11,235 & 10,112 \\
\hline 2,994 & $W$ & $\mathbf{G}$ & 1,000 & 88 & $\mathbf{N}$ & $E$ & $P$ & $\mathrm{~N}$ & $\mathbf{R}$ & 10,840 & 7,154 \\
\hline 2,995 & $\bar{W}$ & $\mathbf{G}$ & 1,000 & 93 & $\mathrm{~N}$ & $E$ & $P$ & $\mathrm{~N}$ & $\mathbf{R}$ & 14,000 & 12,796 \\
\hline 2,996 & $W$ & $\mathbf{G}$ & 1,000 & 93 & $\mathbf{N}$ & $S$ & $L$ & & $\mathbf{R}$ & 9,975 & 8,978 \\
\hline 2,997 & $\bar{W}$ & $\mathbf{G}$ & 300 & 80 & $S$ & $E$ & $\bar{A}$ & $\mathbf{N}$ & $R$ & 2,088 & 1,879 \\
\hline 2,998 & $w$ & $\mathbf{G}$ & 300 & 83 & $S$ & $E$ & $A$ & $N$ & $R$ & 4,178 & 3,760 \\
\hline 2,999 & $\mathrm{~s}$ & G & 300 & 83 & S & $\bar{E}$ & A & $\mathbf{N}$ & $R$ & 5,980 & 5,382 \\
\hline 3,000 & $S$ & $G$ & 300 & 80 & $S$ & $E$ & $\bar{A}$ & $\mathbf{N}$ & $R$ & 3,690 & 3,321 \\
\hline 3,001 & W & G & 400 & 80 & $S$ & $\mathrm{E}$ & $A$ & $N$ & $\mathbf{R}$ & 2,511 & 2,260 \\
\hline 3,002 & $W$ & $\mathbf{G}$ & 400 & 83 & $S$ & $E$ & $A$ & $\mathbf{N}$ & $\mathbf{R}$ & 4,601 & 4,141 \\
\hline 3,003 & $S$ & $\mathbf{G}$ & 400 & 83 & $S$ & $\bar{E}$ & A & $\mathbf{N}$ & $R$ & 7,140 & 6,426 \\
\hline 3,004 & $\mathrm{~S}$ & $\mathbf{G}$ & 400 & 80 & $S$ & $\mathrm{E}$ & A & $\mathrm{N}$ & $R$ & 4,680 & 4,212 \\
\hline 3,005 & $S$ & $\mathbf{G}$ & 400 & 86 & $S$ & $E$ & $P$ & $\mathrm{~N}$ & $\mathbf{R}$ & 10,854 & 9,769 \\
\hline 3,006 & $S$ & $\mathbf{G}$ & 430 & 83 & $S$ & $E$ & $A$ & $\mathrm{~N}$ & $\mathbf{R}$ & 7,340 & 6,606 \\
\hline 3,007 & $S$ & $\mathbf{G}$ & 430 & 80 & S & $\bar{E}$ & A & $N$ & $R$ & 4,880 & 4,392 \\
\hline 3,008 & $w$ & $\mathbf{G}$ & 490 & 80 & $S$ & $\bar{E}$ & A & $\mathbf{N}$ & $\mathbf{R}$ & 2,772 & 2,495 \\
\hline 3,009 & $W$ & $\mathbf{G}$ & 490 & 83 & $S$ & $\bar{E}$ & $A$ & $\bar{N}$ & $R$ & 4,862 & 4,376 \\
\hline 3,010 & $s$ & $\mathbf{G}$ & 520 & 86 & $S$ & $\bar{E}$ & $P$ & $N$ & $\mathbf{R}$ & 12,069 & 10,862 \\
\hline 3,011 & $W$ & $\mathrm{G}$ & 530 & 80 & $S$ & $E$ & $P$ & $N$ & $\mathrm{R}$ & 7,596 & 6,836 \\
\hline 3,012 & $W$ & $\mathbf{G}$ & 600 & 80 & S & $\bar{E}$ & $A$ & $\mathbf{N}$ & $\mathbf{R}$ & 2,970 & 2,673 \\
\hline 3,013 & $w$ & $\mathbf{G}$ & 600 & 83 & $S$ & $\bar{E}$ & $A$ & $N$ & $\mathbf{R}$ & 5,280 & 4,752 \\
\hline 3,014 & $S$ & $\mathbf{G}$ & 650 & 83 & $S$ & $E$ & A & $N$ & $R$ & 9,200 & 8,280 \\
\hline 3,015 & $S$ & $\mathbf{G}$ & 650 & 80 & $\mathrm{~s}$ & $E$ & $A$ & $\mathbf{N}$ & $\mathbf{R}$ & 6,030 & 5,427 \\
\hline
\end{tabular}


Table A.5. Packaged Boilers (contd)

\begin{tabular}{|c|c|c|c|c|c|c|c|c|c|c|c|}
\hline REC & TYPE & $\overline{\text { FUEL }}$ & INPUT & EFF & $\overline{E X C H}$ & $\overline{I G N}$ & BURN & VENT & CTYPE & LCOST & CCOST \\
\hline 3,016 & $W$ & $\mathbf{G}$ & 670 & 80 & $S$ & $E$ & $P$ & $N$ & $R$ & 7,866 & 7,079 \\
\hline 3,017 & $\mathrm{~S}$ & $\bar{G}$ & 690 & 86 & S & $E$ & $P$ & $\mathbf{N}$ & R & 12,069 & 10,862 \\
\hline 3,018 & $\mathbf{W}$ & $\mathbf{G}$ & 760 & 80 & $S$ & $E$ & $\mathrm{~A}$ & $\mathbf{N}$ & $\mathbf{R}$ & 3,375 & 3,038 \\
\hline 3,019 & $W$ & G & 760 & 83 & $\mathrm{~S}$ & $E$ & $\bar{A}$ & $\mathbf{N}$ & $\mathrm{R}$ & 6,405 & 5,765 \\
\hline 3,020 & $\mathrm{~s}$ & $G$ & 860 & 83 & $\mathrm{~S}$ & $E$ & A & $N$ & $\mathbf{R}$ & 11,080 & 9,972 \\
\hline 3,021 & $S$ & G & 860 & 80 & $\mathrm{~S}$ & $E$ & $\bar{A}$ & $\mathrm{~N}$ & $\mathbf{R}$ & 7,470 & 6,723 \\
\hline 3,022 & $W$ & $\mathbf{G}$ & 860 & 80 & $S$ & $E$ & $P$ & $\mathrm{~N}$ & $\mathbf{R}$ & 8,388 & 7,549 \\
\hline 3,023 & $\mathrm{~S}$ & $G$ & 950 & 86 & $S$ & $E$ & $P$ & $N$ & $R$ & 14,733 & 13,260 \\
\hline 3,024 & $W$ & $G$ & 970 & 80 & $S$ & $E$ & A & $N$ & $\mathrm{R}$ & 4,527 & 4,074 \\
\hline 3,025 & $W$ & G & 970 & 83 & $\mathrm{~S}$ & $E$ & $\bar{A}$ & $\mathrm{~N}$ & $\bar{R}$ & 7,497 & 6,747 \\
\hline 3,026 & $W$ & $G$ & 1,010 & 80 & $\bar{S}$ & $E$ & $\mathrm{P}$ & $\mathrm{N}$ & $\mathbf{R}$ & 9,396 & 8,456 \\
\hline 3,027 & $\mathrm{~S}$ & $G$ & 1,080 & 83 & $S$ & $E$ & $A$ & $\mathrm{~N}$ & $\bar{R}$ & 11,530 & 10,377 \\
\hline 3,028 & S & $G$ & 1,080 & 80 & $\mathrm{~S}$ & $E$ & A & $N$ & $\mathbf{R}$ & 7,920 & 7,128 \\
\hline 3,029 & $W$ & G & 1,140 & 80 & $S$ & $E$ & A & $\mathrm{N}$ & R & 4,797 & 4,317 \\
\hline 3,030 & $W$ & G & 1,140 & 83 & $S$ & $E$ & A & $\mathbf{N}$ & $R$ & 7,767 & 6,990 \\
\hline 3,031 & $S$ & $\mathbf{G}$ & 1,260 & 83 & $S$ & $E$ & A & $N$ & $\mathrm{R}$ & 13,968 & 12,571 \\
\hline 3,032 & $S$ & $\mathbf{G}$ & 1,260 & 80 & S & $E$ & $\mathrm{~A}$ & $\mathbf{N}$ & $\mathrm{R}$ & 10,358 & 9,322 \\
\hline 3,033 & $S$ & G & 1,260 & 86 & $\mathrm{~S}$ & $E$ & $P$ & $\mathrm{~N}$ & $\mathrm{R}$ & 16,542 & 14,888 \\
\hline 3,034 & $w$ & G & 1,300 & 80 & $S$ & $E$ & $P$ & $\mathrm{~N}$ & $\mathbf{R}$ & 11,934 & 10,741 \\
\hline 3,035 & $\mathbf{W}$ & G & 1,460 & 80 & $\mathrm{~S}$ & $E$ & A & $\mathrm{N}$ & $\mathrm{R}$ & 6,480 & 5,832 \\
\hline 3,036 & W & G & 1,460 & 83 & S & $E$ & A & $\mathrm{N}$ & $R$ & 9,890 & 8,901 \\
\hline 3,037 & $W$ & G & 1,540 & 80 & $\mathrm{~S}$ & $E$ & $P$ & $\mathbf{N}$ & $\mathrm{R}$ & 12,537 & 11,283 \\
\hline 3,038 & $S$ & $\mathbf{G}$ & 1,680 & 83 & $S$ & $E$ & $\bar{A}$ & $N$ & R & 15,140 & 13,626 \\
\hline 3,039 & S & $\mathbf{G}$ & 1,680 & 80 & $\mathrm{~S}$ & $E$ & $\mathrm{~A}$ & $\mathbf{N}$ & $\mathbf{R}$ & 11,610 & 10,449 \\
\hline 3,040 & $\mathrm{~S}$ & G & 1,680 & 86 & $S$ & $E$ & $P$ & $N$ & $\mathrm{R}$ & 18,414 & 16,573 \\
\hline 3,041 & $\bar{W}$ & G & 1,730 & 80 & $S$ & $E$ & A & $\mathrm{N}$ & $R$ & 6,750 & 6,075 \\
\hline 3,042 & W & $G$ & 1,730 & 83 & $\bar{S}$ & $E$ & A & $\mathrm{N}$ & $\mathrm{R}$ & 10,160 & 9,144 \\
\hline 3,043 & $\bar{W}$ & $\mathbf{G}$ & 1,920 & 80 & $S$ & $E$ & $P$ & $\mathrm{~N}$ & $\mathrm{R}$ & 13,941 & 12,547 \\
\hline 3,044 & $S$ & $G$ & 2,000 & 83 & $S$ & $\bar{E}$ & A & $\mathrm{N}$ & $\mathrm{R}$ & 16,740 & 15,066 \\
\hline 3,045 & $S$ & $\mathbf{G}$ & 2,000 & 80 & $S$ & $E$ & A & $N$ & $\mathrm{R}$ & 13,410 & 12,069 \\
\hline 3,046 & $W$ & G & 2,000 & 80 & $S$ & $E$ & $\bar{A}$ & $\mathrm{~N}$ & $R$ & 7,695 & 6,926 \\
\hline 3,047 & 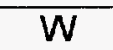 & G & 2,000 & 83 & $S$ & $E$ & $\bar{A}$ & $N$ & $\mathrm{R}$ & 11,025 & 9,923 \\
\hline 3,048 & $\mathrm{~S}$ & G & 2,100 & 83 & $S$ & $E$ & A & $\mathrm{N}$ & $\mathrm{R}$ & 16,740 & 15,066 \\
\hline 3,049 & $S$ & $G$ & 2,100 & 80 & $S$ & $E$ & A & $\mathrm{N}$ & $\mathrm{R}$ & 13,410 & 12,069 \\
\hline 3,050 & $S$ & G & 2,100 & 86 & $S$ & $E$ & $P$ & $\mathrm{~N}$ & $R$ & 20,475 & 18,428 \\
\hline 3,051 & W & $\mathbf{G}$ & 2,160 & 80 & $S$ & $E$ & A & $\mathrm{N}$ & $\mathrm{R}$ & 7,695 & 6,926 \\
\hline 3,052 & W & $\mathbf{G}$ & 2,160 & 83 & $S$ & $E$ & A & $N$ & $\mathrm{R}$ & 11,025 & 9,923 \\
\hline 3,053 & $W$ & G & 2,300 & 80 & $S$ & $E$ & $P$ & $N$ & $R$ & 15,597 & 14,037 \\
\hline 3,054 & $\bar{W}$ & G & 2,490 & 80 & $S$ & $E$ & A & $\mathrm{N}$ & $R$ & 7,695 & 6,926 \\
\hline 3,055 & W & G & 2,490 & 83 & $S$ & $E$ & A & $\mathrm{N}$ & $R$ & 11,025 & 9,923 \\
\hline 3,056 & W & G & 2,600 & 80 & $S$ & $E$ & A & $\bar{N}$ & $R$ & 9,180 & 8,262 \\
\hline 3,057 & $W$ & G & 2,600 & 83 & $S$ & $E$ & $A$ & $\mathbf{N}$ & $\mathrm{R}$ & 13,160 & 11,844 \\
\hline 3,058 & W & $\mathbf{G}$ & 2,640 & 80 & $S$ & $E$ & $P$ & $N$ & $R$ & 18,018 & 16,216 \\
\hline 3,059 & $S$ & $G$ & 2,940 & 83 & $S$ & $\bar{E}$ & A & $\mathrm{N}$ & $R$ & 20,900 & 18,810 \\
\hline 3,060 & $S$ & $G$ & 2,940 & 80 & $S$ & $E$ & A & $\mathrm{N}$ & $R$ & 16,920 & 15,228 \\
\hline
\end{tabular}


Table A.5. Packaged Boilers (contd)

\begin{tabular}{|c|c|c|c|c|c|c|c|c|c|c|c|}
\hline REC & TYPE & FUEL & INPUT & EFF & $\mathrm{EXCH}$ & IGN & BURN & VENT & CTYPE & LCOST & Ccost \\
\hline 3,061 & $S$ & $\mathbf{G}$ & 2,940 & 86 & $S$ & $E$ & $P$ & $N$ & $\mathrm{R}$ & 25,020 & 22,518 \\
\hline 3,062 & $W$ & $\mathbf{G}$ & 2,970 & 80 & $S$ & $E$ & A & $\bar{N}$ & $\bar{R}$ & 9,648 & 8,683 \\
\hline 3,063 & $W$ & $\mathbf{G}$ & 2,970 & 83 & $S$ & $E$ & $\bar{A}$ & $\mathbf{N}$ & $R$ & 13,628 & 12,265 \\
\hline 3,064 & $\bar{W}$ & G & 3,120 & 80 & $S$ & $E$ & $P$ & $\mathbf{N}$ & $R$ & 19,674 & 17,707 \\
\hline 3,065 & $\bar{W}$ & $\mathbf{G}$ & 3,460 & 80 & s & $E$ & $P$ & $N$ & $R$ & 20,655 & 18,590 \\
\hline 3,066 & $W$ & $G$ & 3,600 & 80 & S & $\bar{E}$ & A & $N$ & $R$ & 11,133 & 10,020 \\
\hline 3,067 & $W$ & $G$ & 3,600 & 83 & $S$ & $E$ & $A$ & $\mathrm{~N}$ & $\mathbf{R}$ & 14,893 & 13,404 \\
\hline 3,068 & $S$ & $G$ & 3,780 & 83 & S & $E$ & A & $\mathrm{N}$ & $\mathbf{R}$ & 24,360 & 21,924 \\
\hline 3,069 & $S$ & G & 3,780 & 80 & $\mathrm{~S}$ & $E$ & $\mathrm{~A}$ & $\mathbf{N}$ & $\mathbf{R}$ & 19,260 & 17,334 \\
\hline 3,070 & $S$ & G & 3,780 & 86 & 5 & $E$ & $\mathrm{P}$ & $\mathrm{N}$ & $\mathbf{R}$ & 28,656 & 25,790 \\
\hline 3,071 & $W$ & $\mathbf{G}$ & 3,900 & 80 & $S$ & $E$ & A & $\mathrm{N}$ & $\mathbf{R}$ & 11,673 & 10,506 \\
\hline 3,072 & $W$ & G & 3,900 & 83 & $S$ & $E$ & A & $N$ & $\mathbf{R}$ & 16,773 & 15,096 \\
\hline 3,073 & $W$ & $G$ & 4,030 & 80 & S & $E$ & $P$ & $N$ & $\mathrm{R}$ & 22,761 & 20,485 \\
\hline 3,074 & $\mathbf{W}$ & $G$ & 4,600 & 80 & $S$ & $E$ & $A$ & $\mathrm{~N}$ & $\bar{R}$ & 13,365 & 12,029 \\
\hline 3,075 & $W$ & $G$ & 4,600 & 83 & $S$ & $E$ & A & $\mathrm{N}$ & $R$ & 18,465 & 16,619 \\
\hline 3,076 & $S$ & $G$ & 4,830 & 83 & $S$ & $E$ & $\bar{A}$ & $\bar{N}$ & $\mathrm{R}$ & 27,240 & 24,516 \\
\hline 3,077 & $S$ & G & 4,830 & 80 & $S$ & $E$ & A & $N$ & $\bar{R}$ & 22,140 & 19,926 \\
\hline 3,078 & $S$ & G & 4,830 & 86 & 5 & $E$ & $P$ & $\mathrm{~N}$ & $\mathrm{R}$ & 32,040 & 28,836 \\
\hline 3,079 & $\bar{W}$ & $\mathbf{G}$ & 5,000 & 80 & S & $E$ & $P$ & $\bar{N}$ & $R$ & 26,298 & 23,668 \\
\hline 3,080 & $w$ & G & 5,700 & 80 & $\mathrm{~S}$ & $\mathrm{E}$ & A & $\mathrm{N}$ & $R$ & 16,263 & 14,637 \\
\hline 3,081 & $W$ & G & 5,700 & 83 & S & $E$ & A & $\mathrm{N}$ & $\mathrm{R}$ & 24,233 & 21,810 \\
\hline 3,082 & $w$ & $G$ & 6,250 & 80 & $S$ & $E$ & $P$ & $\bar{N}$ & $\mathrm{R}$ & 28,953 & 26,058 \\
\hline 3,083 & 5 & $\mathbf{G}$ & 6,300 & 83 & $S$ & $E$ & $A$ & $\mathrm{~N}$ & $\mathbf{R}$ & 35,780 & 32,202 \\
\hline 3,084 & $\mathrm{~S}$ & G & 6,300 & 80 & $S$ & $\bar{E}$ & A & $\mathrm{N}$ & $\mathrm{R}$ & 27,810 & 25,029 \\
\hline 3,085 & $S$ & $G$ & 6,300 & 86 & $S$ & $E$ & $P$ & $\bar{N}$ & R & 38,853 & 34,968 \\
\hline 3,086 & $W$ & $G$ & 6,800 & 80 & $S$ & $E$ & $A$ & $N$ & $\bar{R}$ & 18,018 & 16,216 \\
\hline 3,087 & $W$ & $\mathbf{G}$ & 6,800 & 83 & 5 & $E$ & A & $\mathbf{N}$ & $\mathrm{R}$ & 25,988 & 23,389 \\
\hline 3,088 & $W$ & $G$ & 1,470 & 80 & 1 & $E$ & $P$ & $\mathrm{~N}$ & R & 16,399 & 9,019 \\
\hline 3,089 & $W$ & G & 1,740 & 80 & 1 & $E$ & $P$ & $N$ & $\mathrm{R}$ & 17,424 & 9,583 \\
\hline 3,090 & $W$ & G & 2,010 & 80 & 1 & $\bar{E}$ & $P$ & $\mathbf{N}$ & $\mathrm{R}$ & 18,903 & 10,397 \\
\hline 3,091 & $W$ & G & 2,280 & 80 & 1 & $E$ & $P$ & $\mathbf{N}$ & $R$ & 19,866 & 10,926 \\
\hline 3,092 & $W$ & G & 2,550 & 80 & 1 & $E$ & $P$ & $\mathbf{N}$ & $\mathrm{R}$ & 22,391 & 12,315 \\
\hline 3,093 & $W$ & G & 2,820 & 80 & 1 & $E$ & $P$ & $N$ & $R$ & 23,240 & 12,782 \\
\hline 3,094 & $w$ & $G$ & 3,090 & 80 & 1 & $\bar{E}$ & $P$ & $\mathrm{~N}$ & $\mathrm{R}$ & 24,261 & 13,344 \\
\hline 3,095 & $W$ & G & 3,360 & 80 & 1 & $E$ & $\bar{P}$ & $\mathrm{~N}$ & $\mathbf{R}$ & 25,237 & 13,880 \\
\hline 3,096 & $W$ & G & 3,630 & 80 & 1 & $E$ & $P$ & $\mathrm{~N}$ & $\bar{R}$ & 26,978 & 14,838 \\
\hline 3,097 & $W$ & $G$ & 3,900 & 80 & 1 & $E$ & $P$ & $N$ & $\mathrm{R}$ & 27,955 & 15,375 \\
\hline 3,098 & $w$ & 0 & 330 & 83 & 1 & $P$ & $P$ & $\mathbf{N}$ & $R$ & 2,374 & 1,436 \\
\hline 3,099 & $S$ & 0 & 340 & 85 & 1 & $E$ & $P$ & $\bar{Y}$ & $\mathrm{R}$ & 3,938 & 2,757 \\
\hline 3,100 & $W$ & 0 & 340 & 85 & I & $\mathrm{E}$ & $P$ & $\bar{Y}$ & $R$ & 3,938 & 2,757 \\
\hline 3,101 & $w$ & 0 & 340 & 80 & 1 & $E$ & $P$ & $\bar{N}$ & $\mathrm{R}$ & 5,037 & 3,526 \\
\hline 3,102 & $\mathrm{~S}$ & 0 & 340 & 80 & I & $E$ & $P$ & $\mathrm{~N}$ & $\mathrm{R}$ & 5,030 & 3,521 \\
\hline 3,103 & $S$ & 0 & 360 & 82 & 1 & $P$ & $P$ & $\mathrm{~N}$ & $R$ & 2,903 & 1,756 \\
\hline 3,104 & $W$ & 0 & 400 & 82 & 1 & $P$ & $P$ & $\bar{N}$ & $\mathrm{R}$ & 2,695 & 1,630 \\
\hline 3,105 & $w$ & 0 & 420 & 80 & 1 & $E$ & $P$ & $\mathbf{N}$ & $\mathrm{R}$ & 5,641 & 3,949 \\
\hline
\end{tabular}


Table A.5. Packaged Boilers (contd)

\begin{tabular}{|c|c|c|c|c|c|c|c|c|c|c|c|}
\hline REC & TYPE & FUEL & INPUT & EFF & $\mathrm{EXCH}$ & IGN & BURN & VENT & CTYPE & LCOST & CCOST \\
\hline 3,106 & $S$ & 0 & 420 & 80 & 1 & $E$ & $P$ & $N$ & $R$ & 5,451 & 3,816 \\
\hline 3,107 & $\mathrm{~S}$ & 0 & 430 & 82 & I & $P$ & $P$ & $\mathrm{~N}$ & $\mathbf{R}$ & 3,112 & 1,883 \\
\hline 3,108 & $W$ & 0 & 470 & 81 & $I$ & $P$ & $P$ & $N$ & $\mathbf{R}$ & 2,896 & 1,752 \\
\hline 3,109 & $\mathrm{~S}$ & 0 & 480 & 85 & 1 & $E$ & $P$ & $\bar{Y}$ & $\mathrm{R}$ & 4,894 & 3,426 \\
\hline 3,110 & $w$ & 0 & 480 & 85 & 1 & $E$ & $P$ & $\bar{Y}$ & $\mathrm{R}$ & 4,894 & 3,426 \\
\hline 3,111 & $W$ & 0 & 560 & 80 & I & $E$ & $P$ & $\mathrm{~N}$ & $\mathbf{R}$ & 6,575 & 4,603 \\
\hline 3,112 & $\mathrm{~S}$ & 0 & 560 & 80 & $\mathrm{I}$ & $E$ & $P$ & $\mathrm{~N}$ & $\mathbf{R}$ & 6,409 & 4,486 \\
\hline 3,113 & $s$ & 0 & 620 & 84 & $\mathrm{I}$ & $\mathrm{E}$ & $\mathbf{P}$ & $Y$ & $\mathrm{R}$ & 5,431 & 3,802 \\
\hline 3,114 & $W$ & 0 & 620 & 84 & i & $\bar{E}$ & $P$ & $Y$ & $\mathrm{R}$ & 5,431 & 3,802 \\
\hline 3,115 & $W$ & 0 & 700 & 80 & I & $E$ & $P$ & $\mathbf{N}$ & $\mathbf{R}$ & 7,224 & 5,057 \\
\hline 3,116 & $\mathrm{~S}$ & 0 & 700 & 80 & 1 & $E$ & $P$ & $\mathrm{~N}$ & $\mathrm{R}$ & 7,057 & 4,940 \\
\hline 3,117 & $S$ & 0 & 770 & 84 & 1 & $\bar{E}$ & $P$ & $Y$ & $\mathbf{R}$ & 6,348 & 4,444 \\
\hline 3,118 & $W$ & 0 & 770 & 84 & 1 & $\bar{E}$ & $P$ & $\bar{Y}$ & $\mathrm{R}$ & 6,348 & 4,444 \\
\hline 3,119 & $W$ & 0 & 840 & 81 & 1 & $\bar{E}$ & $P$ & $\mathbf{N}$ & $\mathbf{R}$ & 7,468 & 5,228 \\
\hline 3,120 & $\mathrm{~s}$ & 0 & 840 & 81 & 1 & $\bar{E}$ & $P$ & $\mathrm{~N}$ & $R$ & 7,640 & 5,348 \\
\hline 3,121 & $S$ & 0 & 910 & 84 & 1 & $E$ & $P$ & $Y$ & $\mathbf{R}$ & 7,125 & 4,988 \\
\hline 3,122 & $W$ & 0 & 910 & 84 & 1 & $\bar{E}$ & $P$ & $Y$ & $\mathbf{R}$ & 7,125 & 4,988 \\
\hline 3,123 & $\mathrm{~S}$ & 0 & 970 & 84 & 1 & $E$ & $P$ & $\bar{N}$ & $\mathbf{R}$ & 8,992 & 6,294 \\
\hline 3,124 & $W$ & 0 & 970 & 84 & 1 & $E$ & $P$ & $\mathbf{N}$ & 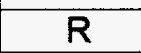 & 8,992 & 6,294 \\
\hline 3,125 & $\mathrm{~S}$ & 0 & 980 & 84 & 1 & $\bar{E}$ & $P$ & $N$ & $R$ & 8,992 & 6,294 \\
\hline 3,126 & $W$ & 0 & 980 & 84 & 1 & $E$ & $\mathbf{P}$ & $N$ & $\mathrm{R}$ & 8,992 & 6,294 \\
\hline 3,127 & $S$ & 0 & 1,050 & 84 & 1 & $E$ & $P$ & $Y$ & $\mathbf{R}$ & 7,489 & 5,242 \\
\hline 3,128 & W & 0 & 1,050 & 84 & I & $\bar{E}$ & $P$ & $\bar{Y}$ & $R$ & 7,489 & 5,242 \\
\hline 3,129 & $\mathrm{~S}$ & 0 & 1,190 & 84 & 1 & $\bar{E}$ & $P$ & $Y$ & $\mathrm{R}$ & 8,019 & 5,613 \\
\hline 3,130 & $W$ & 0 & 1,190 & 84 & 1 & $E$ & $P$ & $Y$ & $\mathrm{R}$ & 8,019 & 5,613 \\
\hline 3,131 & $\bar{W}$ & 0 & 1,260 & 81 & 1 & $\bar{E}$ & $P$ & $N$ & $R$ & 9,125 & 6,388 \\
\hline 3,132 & $\mathrm{~S}$ & 0 & 1,260 & 81 & 1 & $E$ & $\mathbf{P}$ & $N$ & $\mathrm{R}$ & 9,189 & 6,432 \\
\hline 3,133 & $S$ & 0 & 1,320 & 84 & 1 & $E$ & $P$ & $N$ & $\mathrm{R}$ & 10,130 & 7,091 \\
\hline 3,134 & W & 0 & 1,320 & 84 & 1 & $E$ & $P$ & $\mathbf{N}$ & $\mathbf{R}$ & 10,130 & 7,091 \\
\hline 3,135 & $\mathrm{~S}$ & 0 & 1,340 & 84 & 1 & $E$ & $P$ & $\bar{Y}$ & $R$ & 8,539 & 5,977 \\
\hline 3,136 & $w$ & 0 & 1,340 & 84 & 1 & $E$ & $P$ & $Y$ & $\mathrm{R}$ & 8,539 & 5,977 \\
\hline 3,137 & $W$ & 0 & 1,470 & 80 & 1 & $\bar{E}$ & $P$ & $\mathrm{~N}$ & $R$ & 14,788 & 8,133 \\
\hline 3,138 & $\mathrm{~S}$ & 0 & 1,480 & 84 & 1 & $E$ & $P$ & $Y$ & $R$ & 9,072 & 6,350 \\
\hline 3,139 & $W$ & 0 & 1,480 & 84 & 1 & $E$ & $P$ & $Y$ & $\mathbf{R}$ & 9,072 & 6,350 \\
\hline 3,140 & $S$ & 0 & 1,620 & 84 & 1 & $\bar{E}$ & $P$ & $Y$ & $R$ & 9,812 & 6,868 \\
\hline 3,141 & $w$ & 0 & 1,620 & 84 & 1 & $E$ & $P$ & $Y$ & $R$ & 9,812 & 6,868 \\
\hline 3,142 & $S$ & 0 & 1,650 & 84 & 1 & $E$ & $\mathbf{P}$ & $\mathrm{N}$ & $R$ & 11,565 & 8,096 \\
\hline 3,143 & $\bar{W}$ & 0 & 1,650 & 84 & 1 & $E$ & $P$ & $N$ & $\mathbf{R}$ & 11,565 & 8,096 \\
\hline 3,144 & W & 0 & 1,680 & 81 & 1 & $E$ & $P$ & $N$ & $R$ & 10,579 & 7,405 \\
\hline 3,145 & $S$ & 0 & 1,680 & 81 & 1 & $E$ & $\mathbf{P}$ & $\mathbf{N}$ & $R$ & 10,626 & 7,438 \\
\hline 3,146 & W & 0 & 1,740 & 80 & $T$ & $E$ & $\mathbf{P}$ & $N$ & $R$ & 15,813 & 8,697 \\
\hline 3,147 & $\bar{W}$ & 0 & 1,960 & 80 & 1 & $E$ & $\mathbf{P}$ & $\mathbf{N}$ & $\mathbf{R}$ & 12,185 & 8,530 \\
\hline 3,148 & 5 & 0 & 1,960 & 80 & 1 & $E$ & $P$ & $\mathbf{N}$ & $R$ & 12,240 & 8,568 \\
\hline 3,149 & $S$ & 0 & 1,990 & 84 & 1 & $E$ & $P$ & $N$ & $\mathrm{R}$ & 12,873 & 9,011 \\
\hline 3,150 & $w$ & 0 & 1,990 & 84 & 1 & $E$ & $P$ & $\mathbf{N}$ & $\mathrm{R}$ & 12,873 & 9,011 \\
\hline
\end{tabular}


Table A.5. Packaged Boilers (contd)

\begin{tabular}{|c|c|c|c|c|c|c|c|c|c|c|c|}
\hline REC & TYPE & FUEL & INPUT & EFF & $\mathrm{EXCH}$ & IGN & BURN & VENT & CTYPE & LCOST & CcosT \\
\hline 3,151 & $W$ & 0 & 2,010 & 80 & 1 & $E$ & $P$ & $\mathbf{N}$ & $\mathrm{R}$ & 17,002 & 9,351 \\
\hline 3,152 & $\mathrm{~W}$ & 0 & 2,280 & 80 & $T$ & $E$ & $P$ & $N$ & $\mathbf{R}$ & 17,965 & 9,881 \\
\hline 3,153 & 5 & 0 & 2,320 & 84 & I & $\bar{E}$ & $P$ & $\mathrm{~N}$ & $R$ & 14,050 & 9,835 \\
\hline 3,154 & $W$ & 0 & 2,320 & 84 & 1 & $E$ & $P$ & $\mathrm{~N}$ & $R$ & 14,050 & 9,835 \\
\hline 3,155 & $S$ & 0 & 2,410 & 84 & 1 & $\bar{E}$ & $P$ & $N$ & $R$ & 15,301 & 10,711 \\
\hline 3,156 & $\bar{W}$ & 0 & 2,410 & 84 & 1 & $E$ & $P$ & $\mathbf{N}$ & $\mathbf{R}$ & 15,301 & 10,711 \\
\hline 3,157 & S & 0 & 2,450 & 84 & 1 & $E$ & $P$ & $\mathrm{~N}$ & $R$ & 23,342 & 16,339 \\
\hline 3,158 & $W$ & 0 & 2,450 & 84 & 1 & $\overrightarrow{\mathrm{E}}$ & $P$ & $N$ & $R$ & 23,342 & 16,339 \\
\hline 3,159 & W & 0 & 2,520 & 82 & $\mathrm{~T}$ & $E$ & $P$ & $N$ & $R$ & 14,777 & 10,344 \\
\hline 3,160 & $\mathrm{~s}$ & 0 & 2,520 & 82 & I & $E$ & $\mathrm{P}$ & $N$ & $R$ & 14,943 & 10,460 \\
\hline 3,161 & W & 0 & 2,550 & 80 & $\mathrm{~T}$ & $E$ & $P$ & $\mathbf{N}$ & $R$ & 20,484 & 11,266 \\
\hline 3,162 & $\mathrm{~S}$ & 0 & 2,630 & 84 & 1 & $\bar{E}$ & $P$ & $N$ & $R$ & 15,357 & 10,750 \\
\hline 3,163 & $W$ & 0 & 2,630 & 84 & I & $\overline{\mathrm{E}}$ & $P$ & $N$ & $R$ & 15,357 & 10,750 \\
\hline 3,164 & $S$ & 0 & 2,800 & 84 & 1 & $E$ & $P$ & $\mathbf{N}$ & $R$ & 16,516 & 11,561 \\
\hline 3,165 & $W$ & 0 & 2,800 & 84 & I & $\bar{E}$ & $P$ & $N$ & $R$ & 16,516 & 11,561 \\
\hline 3,166 & $S$ & 0 & 2,800 & 84 & 1 & $E$ & $P$ & $\mathrm{~N}$ & $\mathrm{R}$ & 25,153 & 17,607 \\
\hline 3,167 & $\mathrm{~W}$ & 0 & 2,800 & 84 & $T$ & $E$ & $P$ & $N$ & $R$ & 25,153 & 17,607 \\
\hline 3,168 & $W$ & 0 & 2,820 & 80 & 1 & $\bar{E}$ & $P$ & $N$ & $R$ & 21,333 & 11,733 \\
\hline 3,169 & $S$ & 0 & 3,010 & 84 & 1 & $\bar{E}$ & $P$ & $\mathbf{N}$ & $R$ & 16,985 & 11,890 \\
\hline 3,170 & $W$ & 0 & 3,010 & 84 & 1 & $\bar{E}$ & $P$ & $N$ & $\mathrm{R}$ & 16,985 & 11,890 \\
\hline 3,171 & $W$ & 0 & 3,090 & 80 & 1 & $E$ & $P$ & $\mathbf{N}$ & $R$ & 22,354 & 12,295 \\
\hline 3,172 & $\mathrm{~S}$ & 0 & 3,150 & 84 & 1 & $\bar{E}$ & $P$ & $\mathrm{~N}$ & $R$ & 27,208 & 19,046 \\
\hline 3,173 & $\mathbf{W}$ & 0 & 3,150 & 84 & 1 & $E$ & $P$ & $\mathrm{~N}$ & $R$ & 27,208 & 19,046 \\
\hline 3,174 & $S$ & 0 & 3,290 & 84 & I & $\bar{E}$ & $P$ & $N$ & $R$ & 18,255 & 12,779 \\
\hline 3,175 & $\mathbf{W}$ & 0 & 3,290 & 84 & 1 & $E$ & $P$ & $N$ & $R$ & 18,255 & 12,779 \\
\hline 3,176 & $w$ & 0 & 3,360 & 80 & 1 & $E$ & $P$ & $N$ & $R$ & 23,330 & 12,832 \\
\hline 3,177 & $\mathrm{~S}$ & 0 & 3,500 & 84 & 1 & $\bar{E}$ & $P$ & $\mathrm{~N}$ & $R$ & 29,029 & 20,320 \\
\hline 3,178 & $w$ & 0 & 3,500 & 84 & I & $\bar{E}$ & $P$ & $\mathrm{~N}$ & $R$ & 29,029 & 20,320 \\
\hline 3,179 & $W$ & 0 & 3,630 & 80 & 1 & $\bar{E}$ & $P$ & $N$ & $\mathrm{R}$ & 24,373 & 13,405 \\
\hline 3,180 & $S$ & 0 & 3,640 & 84 & 1 & $E$ & $P$ & $N$ & $R$ & 19,445 & 13,612 \\
\hline 3,181 & $W$ & 0 & 3,640 & 84 & 1 & $\bar{E}$ & $P$ & $N$ & $R$ & 19,445 & 13,612 \\
\hline 3,182 & $\mathrm{~S}$ & 0 & 3,850 & 84 & 1 & $\bar{E}$ & $P$ & $\mathrm{~N}$ & $\mathrm{R}$ & 30,840 & 21,588 \\
\hline 3,183 & $w$ & 0 & 3,850 & 84 & 1 & $\bar{E}$ & $P$ & $\bar{N}$ & $R$ & 30,840 & 21,588 \\
\hline 3,184 & $w$ & 0 & 3,900 & 80 & I & $\bar{E}$ & $P$ & $\mathrm{~N}$ & $\mathrm{R}$ & 25,350 & 13,943 \\
\hline 3,185 & $\mathrm{~S}$ & 0 & 3,990 & 84 & 1 & $E$ & $P$ & $\mathrm{~N}$ & $R$ & 20,636 & 14,445 \\
\hline 3,186 & $\mathrm{~W}$ & 0 & 3,990 & 84 & $T$ & $E$ & $\mathbf{P}$ & $N$ & $R$ & 20,636 & 14,445 \\
\hline 3,187 & $S$ & 0 & 4,200 & 84 & $T$ & $E$ & $P$ & $\bar{N}$ & $\bar{R}$ & 32,657 & 22,860 \\
\hline 3,188 & $W$ & 0 & 4,200 & 84 & $T$ & $E$ & $P$ & $N$ & $R$ & 32,657 & 22,860 \\
\hline 3,189 & $\mathrm{~S}$ & 0 & 4,340 & 84 & 1 & $E$ & $P$ & $N$ & $\mathrm{R}$ & 22,045 & 15,432 \\
\hline 3,190 & $w$ & 0 & 4,340 & 84 & I & $\bar{E}$ & $P$ & $\mathrm{~N}$ & $R$ & 22,045 & 15,432 \\
\hline 3,191 & 5 & 0 & 4,550 & 84 & I & $\bar{E}$ & $P$ & $\mathrm{~N}$ & R & 35,078 & 24,555 \\
\hline 3,192 & $\mathrm{~W}$ & 0 & 4,550 & 84 & 1 & $E$ & $P$ & $\mathrm{~N}$ & $R$ & 35,078 & 24,555 \\
\hline 3,193 & $S$ & 0 & 4,620 & 84 & 1 & $E$ & $P$ & $\mathrm{~N}$ & $R$ & 23,086 & 16,160 \\
\hline 3,194 & $w$ & 0 & 4,620 & 84 & 1 & $E$ & $P$ & $N$ & $R$ & 23,086 & 16,160 \\
\hline 3,195 & $\mathrm{~S}$ & 0 & 4,900 & 84 & 1 & $\bar{E}$ & $P$ & $N$ & $\mathrm{R}$ & 36,678 & 25,675 \\
\hline
\end{tabular}


Table A.5. Packaged Boilers (contd)

\begin{tabular}{|c|c|c|c|c|c|c|c|c|c|c|c|}
\hline REC & TYPE & FUEL & INPUT & EFF & EXCH & IGN & BURN & VENT & CTYPE & LCOST & CCOST \\
\hline 3,196 & W & O & 4,900 & 84 & I & E & P & N & R & 36,678 & 25,675 \\
\hline 3,197 & S & O & 4,970 & 84 & I & E & P & N & R & 24,298 & 17,009 \\
\hline 3,198 & W & O & 4,970 & 84 & I & E & P & N & R & 24,298 & 17,009 \\
\hline 3,199 & S & O & 5,250 & 84 & I & E & P & N & R & 37,933 & 26,553 \\
\hline 3,200 & W & O & 5,250 & 84 & I & E & P & N & R & 37,933 & 26,553 \\
\hline 3,201 & S & O & 5,320 & 84 & I & E & P & N & R & 25,770 & 18,039 \\
\hline 3,202 & W & O & 5,320 & 84 & I & E & P & N & R & 25,770 & 18,039 \\
\hline 3,203 & S & O & 5,600 & 84 & I & E & P & N & R & 39,420 & 27,594 \\
\hline 3,204 & W & O & 5,600 & 84 & I & E & P & N & R & 39,420 & 27,594 \\
\hline 3,205 & S & O & 5,670 & 83 & I & E & P & N & R & 26,859 & 18,801 \\
\hline 3,206 & W & O & 5,670 & 83 & I & E & P & N & R & 26,859 & 18,801 \\
\hline 3,207 & S & O & 5,950 & 84 & I & E & P & N & R & 41,085 & 28,760 \\
\hline 3,208 & W & O & 5,950 & 84 & I & E & P & N & R & 41,085 & 28,760 \\
\hline 3,209 & S & O & 6,300 & 84 & I & E & P & N & R & 43,785 & 30,650 \\
\hline 3,210 & W & O & 6,300 & 84 & I & E & P & N & R & 43,785 & 30,650 \\
\hline 3,211 & S & O & 6,650 & 84 & I & E & P & N & R & 45,511 & 31,858 \\
\hline 3,212 & W & O & 6,650 & 84 & I & E & P & N & R & 45,511 & 31,858 \\
\hline 3,213 & S & O & 7,000 & 84 & I & E & P & N & R & 46,828 & 32,780 \\
\hline
\end{tabular}


Table A.6. Warm Air Furnaces

\begin{tabular}{|c|c|c|c|c|c|c|}
\hline REC & FUEL & INPUT & EFF & CTYPE & LCOST & CcosT \\
\hline 3,214 & $\mathbf{G}$ & 250 & 80 & $D$ & 3,700 & 5,180 \\
\hline 3,215 & $\mathbf{G}$ & 280 & 80 & $\mathrm{D}$ & 1,920 & 2,688 \\
\hline 3,216 & G & 280 & 80 & D & 1,920 & 2,688 \\
\hline 3,217 & $\mathbf{G}$ & 280 & 80 & $\mathrm{D}$ & 1,920 & 2,688 \\
\hline 3,218 & $\mathbf{G}$ & 350 & 80 & $D$ & 2,250 & 3,150 \\
\hline 3,219 & $G$ & 350 & 80 & $\bar{D}$ & 2,250 & 3,150 \\
\hline 3,220 & $G$ & 350 & 80 & $D$ & 2,250 & 3,150 \\
\hline 3,221 & $\mathbf{G}$ & 500 & 80 & $\bar{D}$ & 4,800 & 6,720 \\
\hline 3,222 & $\mathbf{G}$ & 560 & 80 & D & 3,450 & 4,830 \\
\hline 3,223 & $\mathbf{G}$ & 560 & 80 & $\bar{D}$ & 3,450 & 4,830 \\
\hline 3,224 & $\mathbf{G}$ & 560 & 80 & $\mathrm{D}$ & 3,450 & 4,830 \\
\hline 3,225 & $\mathbf{G}$ & 560 & 80 & $\bar{D}$ & 3,500 & 4,900 \\
\hline 3,226 & $\mathbf{G}$ & 560 & 80 & $D$ & 3,500 & 4,900 \\
\hline 3,227 & $G$ & 560 & 80 & $D$ & 3,500 & 4,900 \\
\hline 3,228 & $\mathbf{G}$ & 1,000 & 80 & $\bar{D}$ & 6,400 & 8,960 \\
\hline 3,229 & 0 & 250 & 83 & $\overline{\mathbf{R}}$ & 2,535 & 1,293 \\
\hline 3,230 & 0 & 250 & 83 & $R$ & 2,535 & 1,293 \\
\hline 3,231 & 0 & 250 & 83 & $\mathbf{R}$ & 2,485 & 1,267 \\
\hline 3,232 & 0 & 250 & 83 & $\mathbf{R}$ & 2,485 & 1,267 \\
\hline 3,233 & 0 & 250 & 83 & $\mathrm{R}$ & 2,535 & 1,293 \\
\hline 3,234 & 0 & 250 & 84 & $\bar{D}$ & 1,040 & 1,352 \\
\hline 3,235 & 0 & 250 & 84 & D & 1,088 & 1,414 \\
\hline 3,236 & 0 & 250 & 84 & D & 1,130 & 1,469 \\
\hline 3,237 & 0 & 250 & 80 & $\bar{D}$ & 3,000 & 4,200 \\
\hline 3,238 & 0 & 250 & 80 & $\overline{\mathrm{R}}$ & 3,678 & 2,023 \\
\hline 3,239 & $\overline{0}$ & 250 & 80 & $R$ & 3,780 & 2,079 \\
\hline 3,240 & 0 & 280 & 80 & D & 1,640 & 2,296 \\
\hline 3,241 & 0 & 280 & 80 & $\mathrm{D}$ & 1,640 & 2,296 \\
\hline 3,242 & 0 & 280 & 80 & $\bar{D}$ & 1,640 & 2,296 \\
\hline 3,243 & 0 & 280 & 80 & $\bar{D}$ & 1,376 & 1,789 \\
\hline 3,244 & 0 & 310 & 80 & $\mathbf{R}$ & 4,222 & 2,322 \\
\hline 3,245 & 0 & 310 & 80 & $R$ & 4,324 & 2,378 \\
\hline 3,246 & 0 & 320 & 82 & $R$ & 3,515 & 1,793 \\
\hline 3,247 & 0 & 320 & 82 & $\bar{R}$ & 3,515 & 1,793 \\
\hline 3,248 & 0 & 320 & 82 & $R$ & 3,425 & 1,747 \\
\hline 3,249 & 0 & 320 & 82 & $\mathrm{R}$ & 3,425 & 1,747 \\
\hline 3,250 & 0 & 320 & 82 & $\bar{R}$ & 3,515 & 1,793 \\
\hline 3,251 & 0 & 350 & 80 & $D$ & 2,000 & 2,800 \\
\hline 3,252 & 0 & 350 & 80 & $D$ & 2,000 & 2,800 \\
\hline 3,253 & 0 & 350 & 80 & D & 2,000 & 2,800 \\
\hline 3,254 & 0 & 350 & 81 & $\bar{D}$ & 1,988 & 2,584 \\
\hline 3,255 & 0 & 350 & 86 & D & 1,958 & 2,545 \\
\hline 3,256 & 0 & 390 & 81 & $D$ & 1,988 & 2,584 \\
\hline 3,257 & 0 & 400 & 80 & $\mathbf{R}$ & 4,538 & 2,496 \\
\hline 3,258 & 0 & 400 & 80 & $R$ & 4,640 & 2,552 \\
\hline
\end{tabular}


Table A.6. Warm Air Furnaces (contd)

\begin{tabular}{|c|c|c|c|c|c|c|}
\hline REC & FUEL & INPUT & EFF & CTYPE & LCOST & CCOST \\
\hline 3,259 & 0 & 420 & 81 & D & 1,988 & 2,584 \\
\hline 3,260 & 0 & 490 & 82 & D & 2,331 & 3,030 \\
\hline 3,261 & 0 & 500 & 80 & D & 3,900 & 5,460 \\
\hline 3,262 & 0 & 560 & 80 & D & 2,530 & 3,542 \\
\hline 3,263 & 0 & 560 & 80 & $D$ & 2,530 & 3,542 \\
\hline 3,264 & 0 & 560 & 80 & $D$ & 2,530 & 3,542 \\
\hline 3,265 & 0 & 560 & 80 & $D$ & 2,550 & 3,570 \\
\hline 3,266 & 0 & 560 & 80 & $D$ & 2,550 & 3,570 \\
\hline 3,267 & 0 & 560 & 80 & $D$ & 2,550 & 3,570 \\
\hline 3,268 & 0 & 630 & 83 & $D$ & 3,150 & 4,095 \\
\hline 3,269 & 0 & 1,000 & 80 & $D$ & 6,100 & 8,540 \\
\hline
\end{tabular}




\section{Distribution}

No. of

Copies

\section{OFFSITE}

12 DOE/Office of Scientific and Technical Information

C. E. Adams

U.S. Department of Energy

1000 Independence Avenue, S.W.

Forrestal Building, EE-431

Washington, D.C. 20585

J. Archibald

U.S. Department of Energy

1000 Independence Avenue, S.W.

Forrestal Building

Washington, D.C. 20585

K. D. DeVine

U.S. Department of Energy

1000 Independence Avenue, S.W.

Forrestal Building, EE-44

Washington, D.C. 20585

M. Ginsberg

U.S. Department of Energy

1000 Independence Avenue, S.W.

Forrestal Building, EE-44

Washington, D.C. 20585

D. M. Hawkins

U.S. Department of Energy

1000 Independence Avenue, S.W.

Forrestal Building, EE-40

Washington, D.C. 20585

W. Hui

U.S. Department of Energy

1000 Independence Avenue, S.W.

Forrestal Building, EE-431

Washington, D.C. 20585
No. of

Copies

R. H. Karney

U.S. Department of Energy

1000 Independence Avenue, S.W.

Forrestal Building, EE-421

Washington, D.C. 20585

\section{R. McLaren}

U.S. Department of Energy

1000 Independence Avenue, S.W.

Forrestal Building, EE-44

Washington, D.C. 20585

C. Nasseri

U.S. Department of Energy

1000 Independence Avenue, S.W.

Forrestal Building, EE-431

Washington, D.C. 20585

2 E. O. Pollock, Jr.

U.S. Department of Energy

1000 Independence Avenue, S.W.

Forrestal Building, EE-431

Washington, D.C. 20585

J. D. Ryan

U.S. Department of Energy

1000 Independence Avenue, S.W.

Forrestal Building, EE-422

Washington, D.C. 20585

R. Mackie

U.S. Department of Energy

1000 Independence Avenue, S.W.

Forrestal Building

Washington, D.C. 20585 
No. of

Copies

ONSITE

DOE Richland Operations Office

J. K. Schmitz
No. of

Copies

28 Pacific Northwest Laboratory

F. E. Barwig, K5-06

J. A. Dirks, K8-18

D. R. Dixon, K8-17

S. L. Freeman, K8-17 (4)

W. D. Hunt, BWO

B. L. Mohler, K5-02

S. A. Parker, K5-08

W. F. Sandusky, K5-08

S. A. Shankle, K8-17

B. J. Snyder, K5-06 (10)

Publishing Coordination

Technical Report Files (5) 